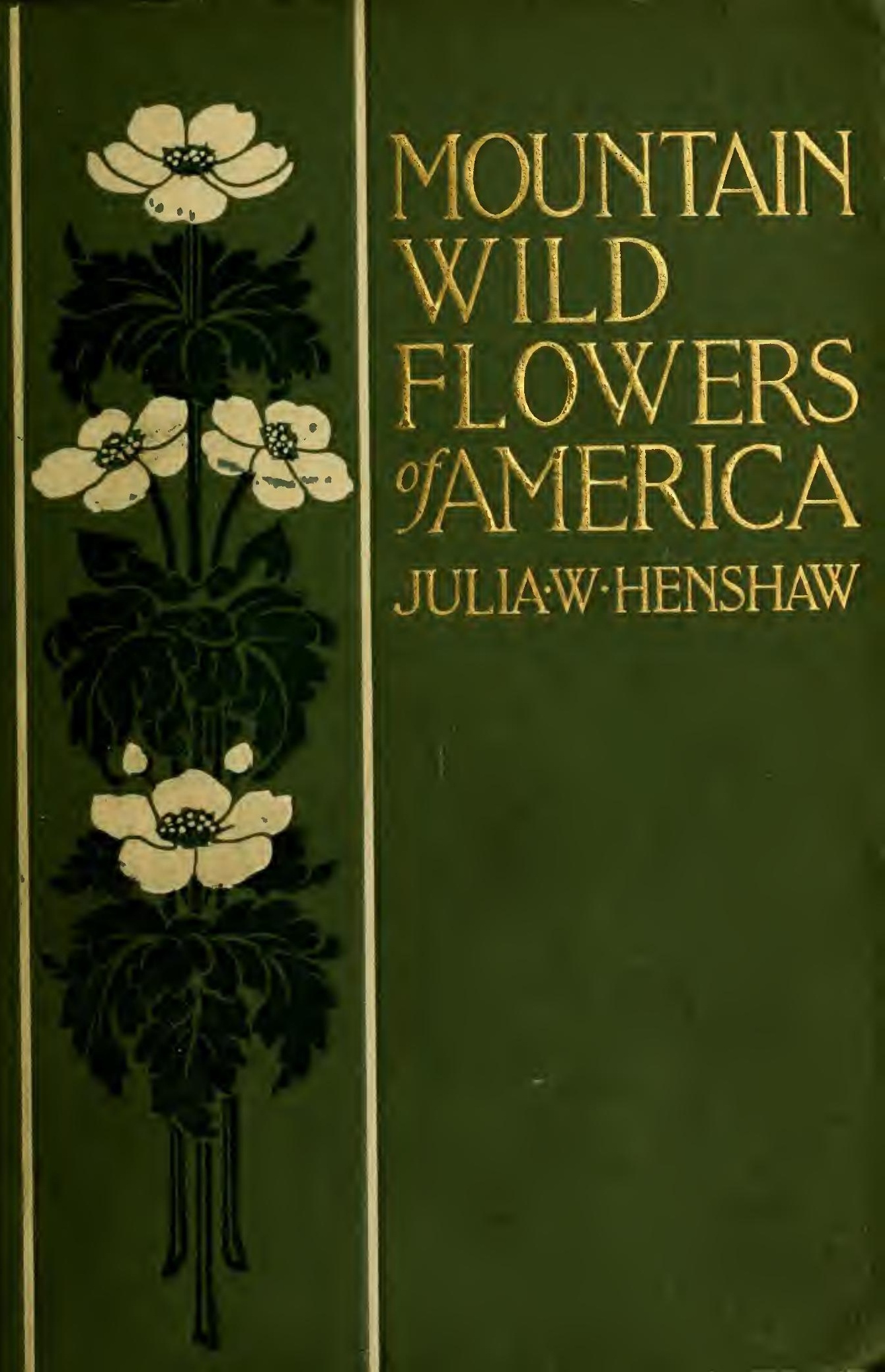



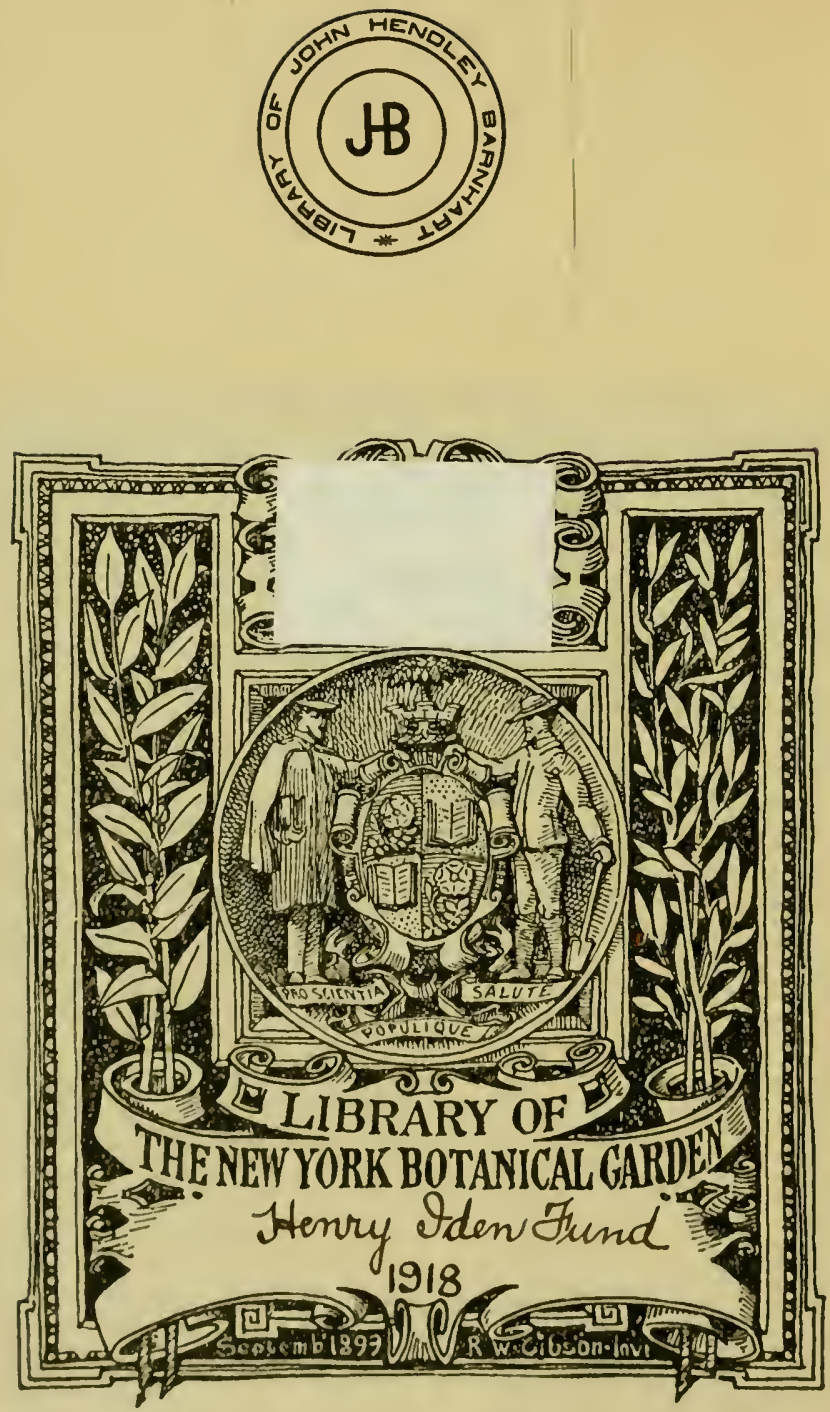





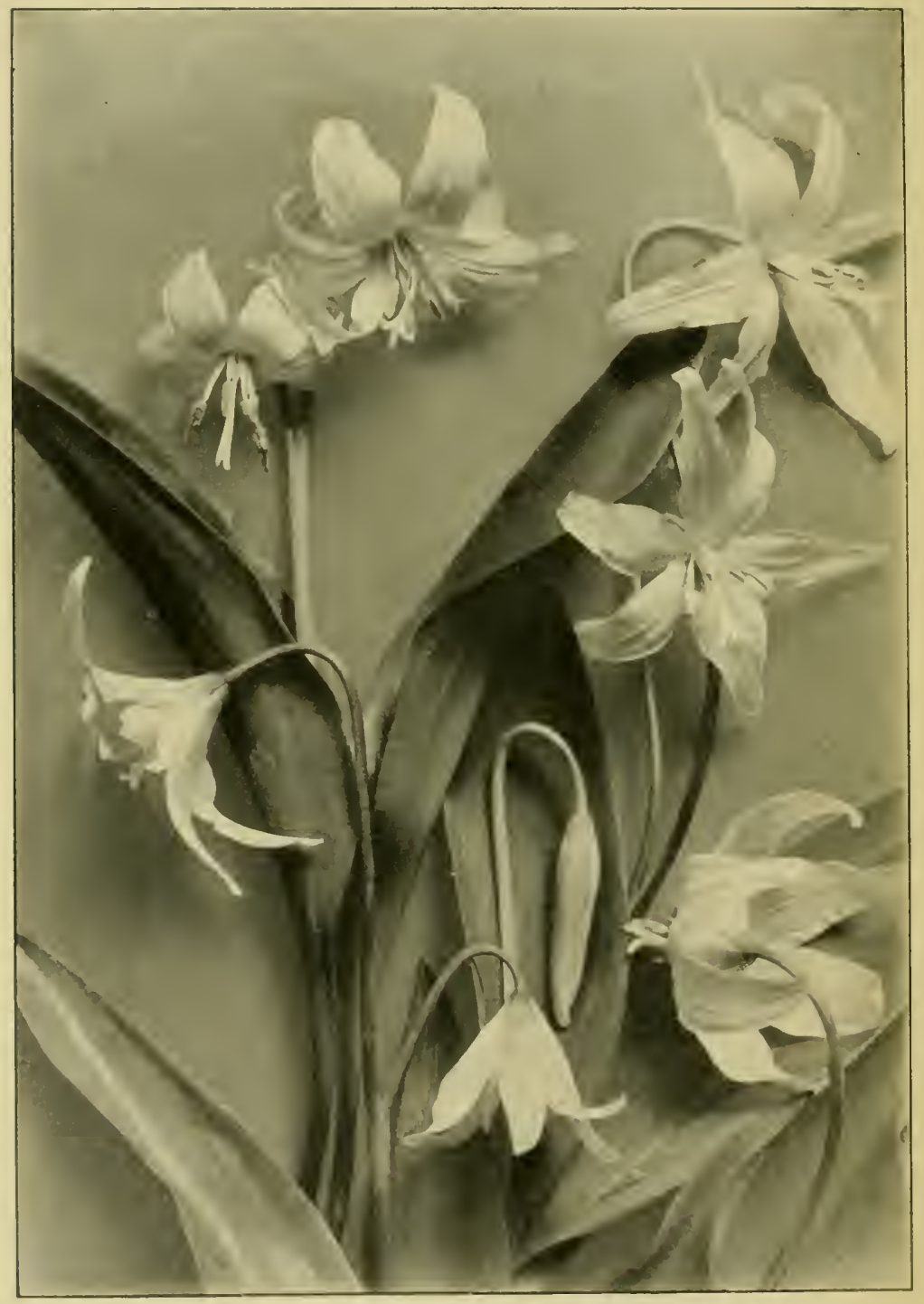

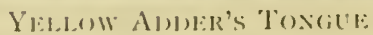

(Iipllironium grgeanteum) 


\title{
MOUNTAIN WILD FLOWERS OF AMERICA
}

A SIMPLE AND POPULAR GUIDE TO THE NAMES AND DESCRIPTIONS OF THE FLOWERS THAT BLOOM ABOVE THE CLOUDS

\author{
$\mathrm{BY}$ \\ JULIA W. HENSHAW
}

L.IBRARY

NEW' YORK

BUTANICAL

GARUEN

BOSTON, U.S.A.

GINN \& COMPANY, PUBLISHERS

The Atbenaum press

1906 
Entered according to Act of Congress, in the year 1906, by

$$
\text { JULIA W. HENSHAW }
$$

in the office of the Librarian of Congress, at Washington

Entered according to Act of the Parliament of Canada, in the year 19o6, by JULIA W. HENSHAW

at the Department of Agriculture

Entered at Stationers' hall

ALL RIGHTS RESERIED

$$
66.6
$$


TO

SIR THOMAS GEORGE SHAUGHNESSY

THIS GUIDE TO THE ALPINE FLOWER-FIELDS

OF THE WEST IS INSCRIBED BY

THE AUTHOR 



\section{PREFACE}

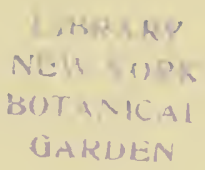

"When the book of life falls open at the page of spring," who does not long to enter the kingdom of Nature and wander therein, with bright-hued flowers abloom about his feet and the silent, scintillating peaks standing circlewise above his head?

High up where the snow-crowned mountain monarchs rule over an enchanting land of foliage, ferns, and fungi, outspanned in sunshine beneath the broad blue tent of the western sky, the alpine meadows are ablaze with starry blossoms. Held close in the curved arms of the cliffs, these patches of verdure and wondrous-tinted flowers are a revelation to the traveller. From the mountains of the Yukon and Alaska to the hills of Nova Scotia and New England, in the Rockies, the Selkirks, and the vast mountain ranges of Montana, Dakota, Washington, Oregon, California, and other western states, one will find that the same miracle has been wrought. On the lower levels, white-flowered, scarlet-fruited shrubs stretch out long branches, weighted with clustered loveliness, across the tiny ribbon-like trails that man has cut deep into the heart of the primeval forest. Over the valleys the water ways have spread an emerald tide of verdure, set with islands of flaming Paintedcups, blue Gentians, and purple Vetches ; while higher up the slopes of the mountains are carpeted with myriads of yellow Lilies, Gaillardias, and Arnicas, - a glorious Field of the Cloth of Gold.

As the traveller climbs upward the scene changes; everywhere there are barren rocks and towering cliffs, huge escarpments and frowning precipices, for here Nature stands revealed in one of her most majestic moods, and all the lines of the 
landscape are sketched out rugged and severe. Then comes the sudden turn round the corner of some cliff, the o'ertopping of some steep stone ledge, and behold! before one lies a garden such as kings might envy. But how describe the ecstasy of standing knee-deep in the fragrance of a thousand flowers? After the crossing of the bare, bleak rocks it is like a triumphal entry into Paradise. Here are pink Garlics, Harebells swaying in wild waywardness, Veronicas looking up with their wideopen blue eyes, Heathers red, rose, and white, amethyst Asters, and sweet-scented Orchids, all mingling their perfume with the shining green leaves and waxen petals of the Rhododendrons and the great snowy chalices of the Globe Flowers.

Who can adequately describe the luxuriant profusion of these alpine meadows? Who can tell in mere words the glory and the glamour of such a scene? All around one the dazzling peaks in their frozen and pitiless beauty point long slender fingers up to God; cruel crevasses split the gigantic rocks from treeless top to pine-clad base, where glaciers cling to the cliffs with sparkling tentacles, and lichened stone-slopes are graciously clothed by the creeping Juniper, and the pale green mantle of Lyall's Larches.

Far below lies the universe in miniature, lakes, rivers, and forests, a few scattered dwellings nestling in the umbrage of the conifers, - "a wondrous woof of various greens" covering the mountain sides, sharp scythe-cut by many a winding pathway or brawling torrent along whose margent the willow wands sway lightly in the wind.

In the foreground is set the splendid sod where prodigal Nature has planted countless fowers, - acre on acre of yellow and scarlet and blue griant Lady's Slippers, delicate Heliotropes, Geraniums, Forget-me-nots, and Columbines. Such is a picture of the Land of Immortal Loveliness, where, far above the clouds, man meets Nature face to face and finds that it is good. 
It matters not at what hour one goes to the mountains, whether in the amethyst dawn, when the golden gates of sunrise fall ajar and the first faint rustle of the leaves stirs the dreaming world to consciousness, dispersing mists and dew; in the brilliant noontide, when life marches on with all her banners unfurled, and every plant is budding and blowing as the sap runs freely and the sun's effulgent rays turn everything to glory; or in the amber evening, when purple shadows steal with phantom feet from cliff to cliff, and down in the depths of the forest the gentle dusk drops tears that spangle leaf and bloom, as God lights the star-lamps of His high heaven and puts out the day.

Even when we listen to the rhythm of the rain all is beautiful, for the flowers that greeted the dawn with opal hearts wide-blown, that at noontide were found with

"Each affluent petal outstretched and uncurled

To the glory and gladness and shine of the world,"

and that at evening offered up sweetest fragrance in their chalice-cups, are given a new joy and beauty by the cool clear showers from above.

"The paths, the woods, the heavens, the hills,

Are not a world today,

But just a place God made for us

In which to play."

So we wander in search of the mountain wild flowers, following the trails that lead to the alpine meadows, listening to the bird-songs as we pass, wrapt in the peace of the perfect hills, while all about us the infinite beauty of things created, the magic of the summer skies, the strength of the far-flung bastions, the purity of the eternal snows, and the glory of the flowers that bloom above the clouds bid us remember that we are walking

with

"In the Freedom of the Garden Wild"

"God of the open Air." 
As this book is intended more for the use of the general public than for botanists, the flowers herein described are classified according to colour, and without special reference to their scientific relationship; for the first attribute of a plant that attracts the traveller's eye is invariably its colour, his first question usually being, What is that red flower? (or blue flower, or yellow flower, as the case may be). Of order, genus, and species he probably knows nothing, and therefore the descriptions given in this guide to the mountain wild flowers are so simply and clearly worded that any plants indexed may be readily located in one of the colour sections, together with its name and chief characteristics.

There are, however, a few botanical terms which it is well the reader should understand; these are given in the "Explanation of Botanical Terms" on page xix.

The nomenclature followed throughout this work is strictly in accordance with that endorsed by Professor John Macoun, botanist to the Federal Government of Canada.

Plants will be found to vary greatly in size and appearance at various altitudes, becoming smaller and shorter as the summits of the mountains are approached, until at 7000 or $\$ 000$ feet one will find the tiny leaves of the Moss Campion and Mountain Saxifrage growing flat upon the ground, their starry blossoms having no perceptible stalks, but being set close down into the moss-like plants. The Aplopappi, Specdwells, Chickweeds, Whitlow-grass, Eriogonums, Androsaces, Saxifrages, and Stonecrops are all in evidence at very high elevations, growing in dwarfed alpine forms, and, together with the Heaths, Heathers, and Anemones, are among the last flowers found at the edge of perpetual snow.

During the course of a short walk in any direction among the mountains, one may gather many excuisite flowers, for he is not obligred to wander far afield in order to find blossoms of every hue: while even to reach tree-line, with its rarer 
species of plants, is not beyond the power of the ordinary traveller who starts out from a châlet hotel at an average altitude of 4500 feet, and therefore has only to climb another couple of thousand feet to arrive at the highest alpine meadows.

For their valuable assistance in the work of preparing this volume upon the mountain wild flowers my sincere and grateful thanks are due to Mr. David McNicoll, Mr. Robert Kerr, and Mr. Richard Marpole.

My sincere thanks are due also to Professor John Macoun, Mr. James Macoun, and Dr. James Fletcher, of Ottawa, for valuable scientific advice and for their interest in my work.

VANCOUVER

April, r 906

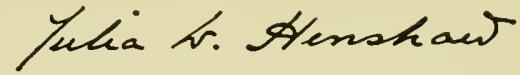





\section{CONTENTS}

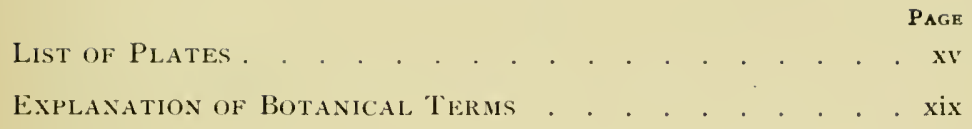

SECTION

I. White to Green Flowers. . . . . . . . . . . . I

Il. Pink to Red Flowers . . . . . . . . . . . . . I 33

III. Blue to Purple Flowers . . . . . . . . . . . 183

IV. Yellow to Orange Flowers. . . . . . . . . . 257

V. Flowerixg Shrubs . . . . . . . . . . . . . 321

VI. Miscellaneous. . . . . . . . . . . . . . 365

IxDex to SCIENTific Names . . . . . . . . . . 377

INDEX to Exglish Names. . . . . . . . . . . . . 38 I 



\section{LIST OF PLATES}

V'ellow Adder's Tongue . . . . . Erythronium giganteum Frontispiece

PLATE

I. Westem Anemone . . . . Anemone dicidentalis. . . . 5

II. Wind-flower . . . : . . Anemone multifida . . . . . 7

III. Alpine Anemone. . . . Anemone Drummondii. . . 11

IV. Globe Flower . . . . . Trollins laxus . . . . . . . 13

V. Irummond's Rock-cress . . Arabis Drummondii . . . . . 17

VI. Canada Violet. . . . . Tiola Canadensis. . . . . 19

VII. Field Chickweed . . . . Cerastum areense . . . . . 23

VIII. Spring beauty. . . . . . Claytonia sessilifolia. . . . . 25

IX. Birch-leaved Spirea . . . Sprra lucida . . . . . . 29

X. White Dryas . . . . . . Dryezs octopetala . . . . . . 33

XI. Common Saxifrage . . . Saxifraga bronchialis . . . 35

XII. Tall Saxifrage . . . . . Sarifraga Lutkana . . . . 39

XIII. Alpine Saxifrage . . . . Saxifraga nizalis . . . . . 41

XIV. Leptarrhena . . . . . Leptarrhena pyrolifolia. . . . 45

XV. Tellima . . . . . . . Tellima grandiflora . . . . 47

XVI. $\left\{\begin{array}{l}\text { Marsh Grass of Parnassus . Parmassia montanensis } \\ \text { Fringed Grass of Pamassus Parnassia fimbriata }\end{array}\right\} \cdot \cdot 51$

XVII. Wild Parsley . . . . . . Ligusticum apiifolium . . . 53

XVIII. Bunch-berry. . . . . . Comms Canadensis . . . . 57

XIX. Northern ledstraw . . . Galium boreale. . . . . . 59

$\mathrm{XX}$. White Heliotrope . . . Taleriana sitchensis . . . . 63

$\mathrm{XXI}$. White Aster . . . . . Aster commutatus . . . . . 65

XXII. Pearly Everlasting . . . Anaphatis margaritacea . . . 69

XXIII. Jarrow . . . . . . Achillea lanulosa . . . . . 7

XXIV. Oxeye Daisy . . . . Chrysanthemam Leuanthemum 75

XXY. White Heath . . . . . Cassiope Mertensiant . . . 77

XXVI. White False Heather . . . Bryanthus glanduliforus . . . SI

XXVII. $\left\{\begin{array}{l}\text { Green-flowered Wintergreen Pyrola chlorantha } \\ \text { Red Wintergreen . . . Pyola asartolia }\end{array}\right\} . . .98_{3}$

XXVIII. One-sided Wintergreen . . Pyrola secunda . . . . . . 87

XXIX. One-flowered Wintergreen. Moneses uniflora . . . . . . 9I

XXX. Romanzoffia . . . . . Komanzoffic sitchensis . . . . 93

XXXI. Contorted Lousewort . . . Pedicularis contorta . . . . . 97

XXXII. $\left\{\begin{array}{l}\text { Alpine Bistort . . . . . Folygonum viziparum } \\ \text { Asphodel . . . . . Tofieldia glutinosa }\end{array}\right\}$. . IOI

XXXIII. Ladies' Tresses . . . . Spiranthes Romanzoffiand. . . 105 
PLATE

PAGE

XXXIV. $\left\{\begin{array}{l}\text { Leafy Orchis . . . . Habenaria hyperbored } \\ \text { Small Orchis.... Habenara obtusata }\end{array}\right\} . .109$

XXXV. White Bog Orchis . . . Hatenaria dilatata. . . . III

XXXVI. White Twisted-stalk . . Streptopus amplexifolius. . I I5

XXXVII. Spikenard . . . . . . Smilacina stellata . . . . I I7

XXXVIII. Queen-cup . . . . . Clintonio uniflora . . . . 1 21

XXXIX. False Hellebore. . . . Teratrum tiride. . . . . 123

XL. Stenanthium . . . . . Stenunthinm decidentale . . 127

XLI. Tall Zygadene . . . . . Zysudemus eleguns . . . . 129

XLIl. Western Columbine . . Aquilegia formosa . . . . I 37

XLIIl. Long-plumed Avens . . . Geum triflorum . . . . . IfI

XLIV. Water Willow-herb . . Epilobium lutifolium . . . I 15

XLV. Northern Twin-flower . . Linnea borealis. . . . . 149

XLVI. Rough Fleabane . . . Erigeron slabellus . . . . 153

XLVII. I'ink Everlasting . . . Antennura farrifoliazar.rosea 157

XlVIII. ked False Heather . . . Bryunthus empetriformis . . I6I

XLIX. Ked Money-flower . . . Mimulus Lenisii . . . . 167

L. Wood betony . . . . Pedicularis brateosa . . . $17 \mathbf{1}$

1.1. Fly-spotted Orchis . . Orchis rotundifoliu. . . . I75

LII. I'ink Garlic . . . . . Allium recurtatum . . . . 179

LIII. Wild Clematis . . . . Clematis Columbiama . . . I\$7

I.IV. Pasque Flower . . . . Anemone liuthalliana. . . ISo

LV. Mountain Larkspur . . . Delphinium firozoniz . . . 193

IVI. Moss Campion . . . . . Silene acanlis . . . . . . . 195

IVII. Wild Flax . . . . . . . Limnm Lecvisii . . . . . . 199

1.V111. Ascending Vetch . . . Astragalus adsurgens. . . 201

I.IX. Alpine Vetch . . . . Astragalus alpinns. . . . 205

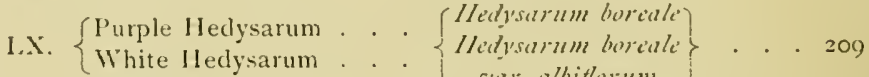

LXI. Cow Vetch. . . . . . Ticiu Craca . . . . . . 211

1.XII. large l'urple Aster . . . Ister conspicus. . . . . 215

LXIII. Large P'urple IJleabane . . Errigeron salsuginosus. . . 217

1.XIV. Brook lobelia . . . . Jobelia Kirmii . . . . . 22 I

LXV. Harebell. . . . . . . . Cimpanula rotundifoliat. . . 225

I.XV1. Macoun's Gentian. . . Cientrunt d/comnii . . . 227

I.XVII. Northern Gientian . . . Contiunt aluta . . . . . 231

1.XVII. Mountain I'hacelia. . . Mharclin resticit. . . . 235

1.XIX. False forget-me-not . . Fichnuspormun fluriburtum . 237

1.XX. large Purple beard-tongue l'enslemon Minstesii . . . 241

1.XXI. Npine Speedwell . . . Ieronia alfina . . . . 245

LXXII. Blue-eyed Cirass . . . Sisprinchimm angustifolinm . 249

1.XXI1. l’urple Garlic . . . . . Allum Schornoprasum . . 253

LXXIV. Vellow Columbine . . . Aguilegia flatescens . . . 263

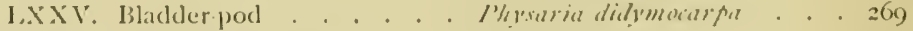

L.XXVI. Jrummond's Dryas . . . Mryus Drmmmombi . . . 273

1.XXViI. Vellow Willow-herl, . . If filotum lutem . . . . 277

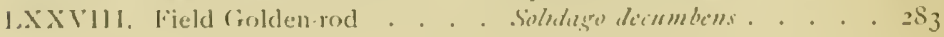


Plate

LXXIX. Giant Sunflower . . . . . Helianthus giganteus . . 287

LXXX. Great-flowered Gaillardia . . Gaillardia aristata . . 29I

LXXXI. Heart-leaf Amica . . . . . Anica cordifoliu . . . 295

LXXXII. Alpine Amica . . . . . . Arnia alfina . . . . 299

LXXXIII. Golden Ragwort . . . . . Senecio Balsamiti . . 303

LXXXIV. Hairy Ilawkweed. . . . . Hieracinm Sconleri. . 307

LXXXY. Small Hawkweed. . . . . Hieracium gracile . . 311

LXXXVI. Large Yellow Lady's Slipper . Cypripedium pubescens . 315

LXXXVII. Red Baneberry. . . . . . Aitiea spicatazar.arguta 325

LXXXVII. Goat's lieard . . . . . . Spirat Aruncus . . . 327

LXXXIX. Salmon-berry . . . . . Kubus lutkanus . . $33^{\mathrm{I}}$

XC. Prickly Rose . . . . . . . Rosa acicularis . . . 333

XCI. Western Mountain Ash . . Pyrus sambucifolia. . 339

XCII. Service-berry . . . . . Amelanchier alnifolia . 341

XCIII. Red-stemmed Dogwood . . Cornus stolonifera . . 345

XCIV. Red-berried Elder . . . . Sambucus racemosa . . 347

XCV. Arrow-wood . . . . . Tiburmum pauciflorum . 35 I

XCVI. Woolly Labrador Tea . . . . Ledum latifolium . . 353

XCVII. White Mountain Rhododendron Rhododendron albiflormm 357

XCVIII. Smooth Menziesia . . . . Menziesia glabella . . 361

XCIX. Cotton Grass . . . . . Eriophormm capitatum . $37 \mathbf{I}$ 



\section{EXPLANATION OF BOTANICAL TERMS}

The object of these pages is to give as brietly as possible a simple explanation of those botanical terms most frequently used in describing plants.

\section{THE ROOT}

Rootstock: a creeping stem, growing below the surface of the ground.

Tuber: a thick portion of a rootstock, usually possessing eyes like a potato.

Corm : the thick fleshy base of a stem.

bulb: an underground stem covered with scales.

Stolon: a basal branch, rooting at the nodes.

\section{THE FRUIT}

Aihene: a dry one-seeded fruit.

Berry: a pulpy fruit.

Capsule: a dry fruit with two or more carpels.

Drupe: a single fruit, with a fleshy outer wall and a bony inner wall.

Plumose: resembling a plume, like the Clematis in seed.

Sterile: without seed.

Erect: upright.

\section{TIE STEM}

Simple: not branched.

Decumbent: horizontal on the ground, but vertical at the end.

Procumbent: Hat on the ground.

Creeping: running along the earth and rooting at the joints.

Scape: the leafless flower-stalk of a stemless plant.

Node: the junction of two portions of the stem, often hard and swollen, at which leaves are usually borne.

\section{THE ILEAF}

Bract: a leaf subtending a flower.

Involucre: a circle of bracts round a flower, as in the Sunflower.

Entire: one the edge of which is not cut or lobed. 
Simple: one which is not divided into leaflets.

Compound: one which is divided into leaflets.

Alternate: when one leaf grows just above the other on another side of the stem.

Opposite: when two appear at each joint, having the semicircle of the stem between them.

Whorled: when they grow in a circle round the stem.

Cordate: heart-shaped.

Obcordate: inversely heart-shaped.

Linear: very narrow, like grass.

Lanceolate: narrow, tapering towards the top.

Oblanceolate: inversely lanceolate.

Oviate: egg-shaped, broader at the bottom.

Oboz'ate: egg-shaped, broader at the top.

Elliptical: oblong, narrowed at the top and bottom.

Oral: broadly elliptical.

Spatulate: rounded at the top and narrow at the base.

Orbicular: round.

Reniform: nearly round, with a deep indentation at the stalk.

Auriculate: having two rounded lobes at the base.

Sagittate: having two pointed lobes at the base.

Undulute: with wavy margins.

Crenate: with rounded teeth on margins.

Serrate: with sharp teeth on margins.

Incised: with deep jagged teeth.

Lobed: with divisions cut to about the middle.

Cleft: with divisions cut more than half way into the leaf.

Diarded: cleft to the midrib.

Pubescent: covered with fine hairs.

Glabrous: without any hairs, smooth.

Glaucous: covered with a bloom, as on the plum.

Mucronate: with a short sharp tip.

\section{THE FLOWER}

Caly $x^{*}$ : the outer lower set of leaves at the base of the flower. Usually green, but sometimes bright coloured.

Sepuls: the leaves of the calyx when it is divided to the base.

Corolla: the inner set of leaves of the flower.

Petals: the leaves of the corolla when it is divided to the base. 
Perianth: said of a flower having only one set of floral leaves.

Pedicel: the small individual stalk of a flower borne in a cluster.

Peduncle: the main flower-stalk.

Sessile: said of flowers that grow close to the stem and have no pedicels.

Raceme: a long-shaped flower-head formed by numerous flowers growing on pedicels along the sides of a common stalk.

Spike: a raceme with sessile flowers.

Head: a dense spike, globular in shape, like a Clover.

Corymb: a raceme with the lower flowers on longer stalks, so that the cluster is almost flat on the top, as in the Yarrow.

Umbel: like a corymb, but with the pedicels all branching from a central point.

Axillary: growing from the axil, or angle, formed by the leaf and the stem.

Stamens: composed of

Filament: the stalk to uphold the anther.

Anther: a tiny box containing the pollen.

Pollen: the fertilizing powder of the plant.

Pistil: composed of

Orary: containing the ovules, or undeveloped seeds.

Style: a slender stalk surmounting the ovary.

Stigma: a variously formed tip of the style, which has a rough moist surface to catch the pollen that fertilizes the seeds by means of minute tubes that penetrate the style and convey the pollen from the stigma to the ovules.

Spadix: a fleshy spike, as in the Arum Lily.

Spathe: the concave bract enveloping a spike. 

MOUNTAIN WILD FLOWERS

\title{
OF AMERICA
}

\author{
Section I
}

WHITE TO GREEN FLOWERS 



\title{
Section I
}

\section{WHITE TO GREEN FLOWERS}

\author{
Flowers that are white to green, or occasionally so, but not \\ described in this Section
}

Alpine Willow-herb . . Efilobium anagallidifolizm (Pink to Red Section) . I47

Hornemann's Willow-herb Efilobium Horncmanni (Pink to Red Section) . . . I4S

Rough.Fleabane . . Erigeron glabellus (Pink to Red Section) . . . . . I52

Pink Everlasting . . Antennaria farvifolia vir. rosea (Pink to Red Section) 152

Alpine Bilberry . . . V'accinium Myrtillus (Pink to Red Section) . . . . 155

Dwarf Bilberry . . . Vaccinizm casfitosum (Pink to Red Section) . . . 155

Mountain Cranberry . . Viacinium litis-Ida (Pink to Red Section) . . 155

Red Bearberry . . . Arctostaphylos Urza-ursi (Pink to Red Section) . . I58

Alpine learberry . . Arctostaphylos alpina (Piink to Red Section) . . I59

Bird'seye Primrose . . Primala farinosa (Pink to Red Section) . . . . . I64

Shooting Star . . . Dodecathion fauciflorum (Pink to Red Section) . . 165

Red Indian Paint-brush . Castilleia seftcntrionalis (Pink to Red Section) . . I66

White Indian Paint-brusl Castillcia pallida (P'ink to Red Section) . . . . . I70

Mountain Larkspur . . Dclphinizm Brownii (Blue to Purple Section) . . . 191

Dog Violet . . . . . V'ioli adunca (Blue to Purple Section) . . . . . . 197

Moss Campion . . . . Silzuc acaulis (Blue to Purple Section) . . . . . 197

Macoun's Vetch . . . Astragalus Macounii (Blue to Purple Section) . . . 204

Purple Vetch . . . Astragalus hypoglotfis (Blue to Purple Section) . . 204

Alpine Oxytrope . . . Oxytrofis ziscida (Blue to Purple Section) . . . . 207

Leafy-bracted Aster . . Aster foliaccus (Blue to Purple Section) . . . . 2I4

Alpine Fleabane . . . Erigcron lanatus (Blue to Purple Section) . . . 220

Arctic Fleabane . . . Erigcron uniforus (Blue to Purple Section) . . . 220

Four-parted Gentian . . Gentiana frofinqua (Blue to Purple Section) . . . 230

Northern Gentian . . . Gentiana acufa (Blue to Purple Section) . . . . . 230

Alpine Gentian . . . Gcntiana arctophila (Blue to Purple Section) . . . $23^{\circ}$

Dwarf Gentian . . . Gontiana frostrata (Blue to Purple Section) . . . 230

Mountain Phacelia. . Phacelia scricea (Blue to Purple Section) . . . . 233

False Forget-me-not . . Echinosformum foribundum (IBlue to Purple Section) 234

Loco-weed . . . . . Oxytrofis Lamberti (Yellow to Orange Section) . . . 272

Small Hawkweed . . Micracium gracilc (Yellow to Orange Section) . . 305

Narrow-leaved Puccoon . Lithospormum angustifolium (Yellow to Orange Section) 309 


\section{WESTERN ANEMONE}

\section{Anemone ociditentalis. Crowfoot Family}

Stems: erect, six to eighteen inches high. Leaves: large, long-petioled, biternate and pinnate. Flowers: large, solitary; petals none; sepals five to seven. Fruit: carpels with long filiform styles that become plumose tails to the achenes.

The Western Anemone is one of the most beautiful of the early spring mountain flowers. Its handsome white cups, purple-shaded on the outside, may be found growing close to the retreating line of snow during the months of May and June, and later on in the season its big fluffy seed-heads are eagerly gathered by those who delight in artistic things. This plant, like many others of the Crowfoot Family, has no petals, only a lovely calyx fashioned into about six sepals, which do duty instead.

\section{WIND-FLOWER}

Anemone multifida. Crowfoot Family

Stems: villous with long silky hairs. Leaves: long-petioled, nearly semicircular in outline, ternate, stem-leaves smaller, nearly sessile. Flowers: of five to eight sepals. Fruit: grobular to oblong; achenes densely woolly:

The Wind-fower, as this delicate little Anemone is usually called, appears on the dry meadows in the spring time in a vast variety of hues, with many blossoms and much fruit. Its colours range from white to red, with many intermediate shades of yellow, pink, and purple-bluc. It is to Pliny, the famous ancient philosopher, that it owes its name, for he declared that only the wind would cause Anemones to open ; while a later poet has sung how Venus in her grief over the death of Adonis "poured out tears amain," and how "gentle flowers" were born to bloom at every drop that fell from her lovely eyes:

"Where streams his blood, there blushing springs the rose, And where a tear has dropped, a wind-flower blows." 


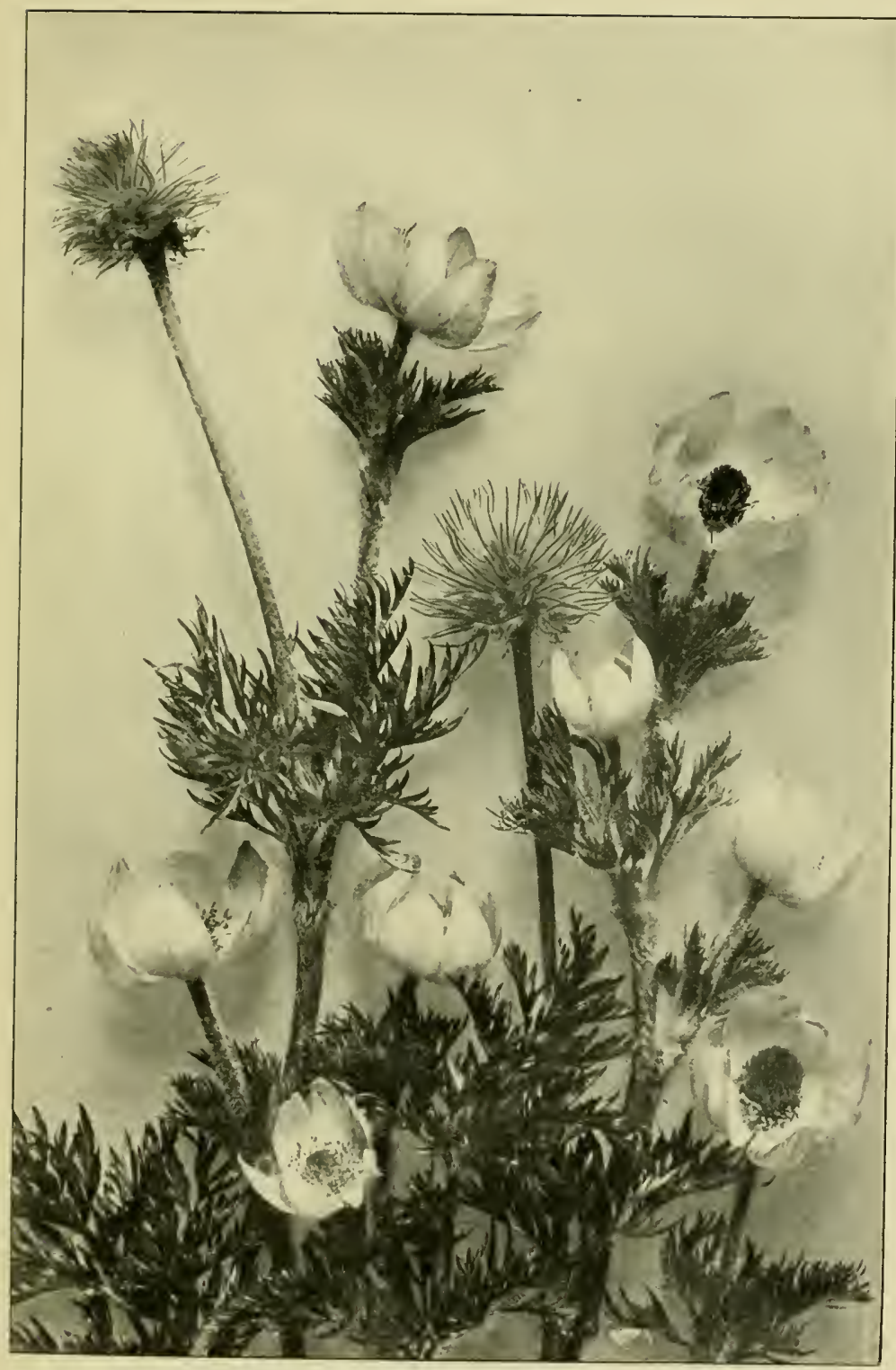

WESTERY ANEMONF

(Anemone accidentalis) 



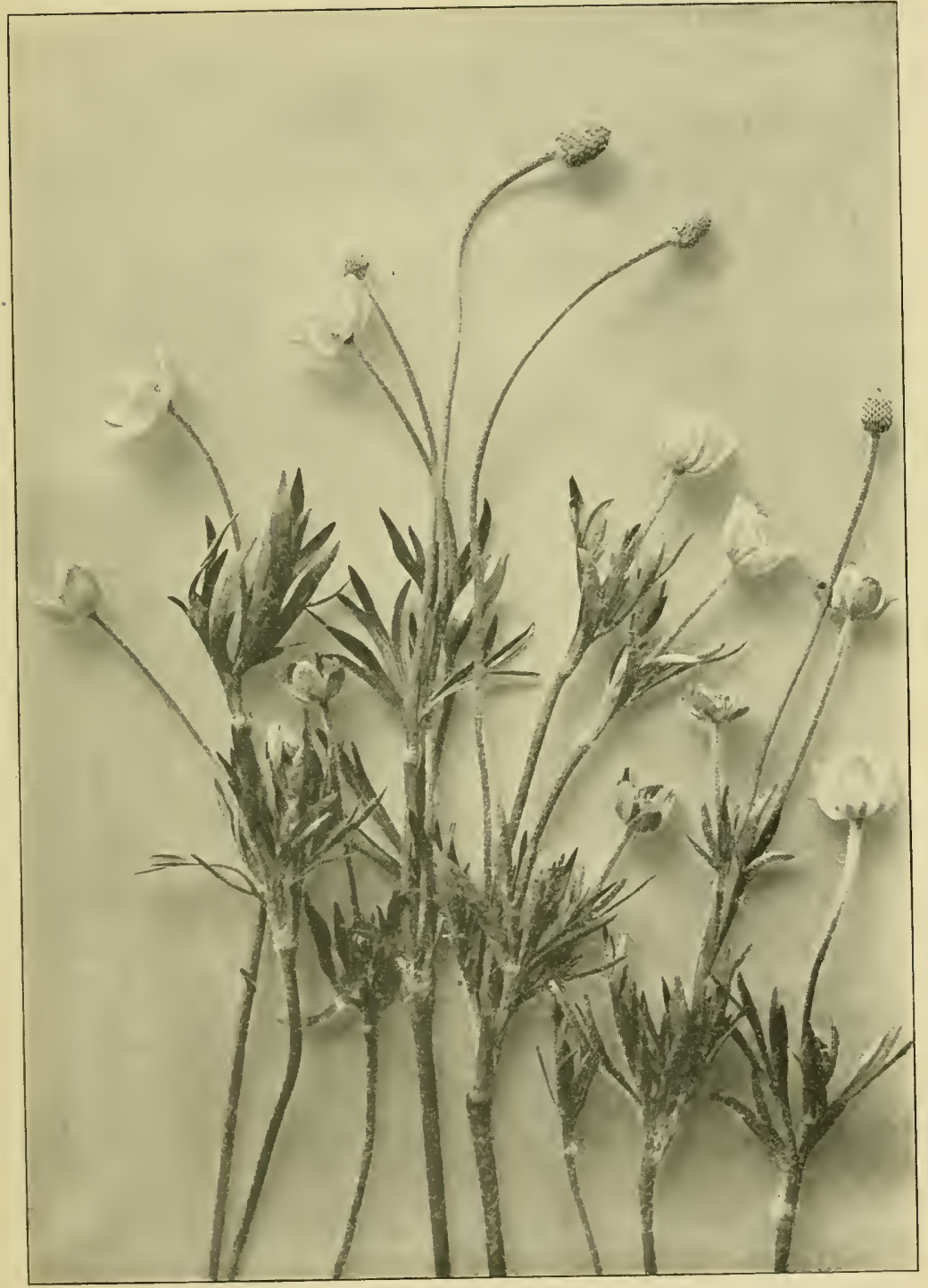

WIND-FLUWER

(Anemone multifida) 

They are short-lived flowers; the wind blows them open and wafts them away. Rapidly the fruit is formed in a thimblelike head, which presently bursts and is seen to contain many white woolly seeds. The leaves are very deeply cleft.

\section{ALPINE ANEMONE}

\section{Anemone Drummondii. Crowfoot Family}

Stems: slender, three to ten inches high from tufted rootstocks. Leaves : on long petioles, ternate, leaflets deeply lobed. Flowers : of five to seven sepals, silky-villous outside; style slender, glabrous. Fruit: achenes densely villous.

The Alpine Anemone has a larger flower and thicker stalks than A. multifide; it also grows higher up on the mountains, and may be found close to perpetual snow. The leaves are set in a circle round the stalk, about two inches below the blossom, and also grow up from the base of the plant. They are not so delicate or deeply cut as those of $A$. multifida. The flower is rather like a white buttercup, and is usually shaded with pale blue on the outside. The centre is yellow and green.

\section{FEW-FLOWERED ANEMONE}

\section{Anemone parriffora. Crowfoot Family}

Stems: erect, very slender. Leaves: basal ones long-petioled, threeparted, the broad wedge-shaped divisions obtusely lobed or crenate, those of the involucre nearly sessile, similarly lobed. Flowers: small, of oval, very obtuse sepals. Fruit: globose; achenes densely woolly.

The smallest and most delicate of all the mountain Anemones, it is usually found growing in the thick forests, single and solitary. The flowers are white, veined and shaded with blue at the base of the sepals. 


\section{MEADOW-RUE}

\section{Thatictrum occidentale. Crowfoot Family}

Stems: slender, one to three feet high. Leaves: ternate, the lower ones petioled. Flowers: nodding on very slender pedicels in an ample open panicle; filaments purplish-green; anther linear, cuspidate; calyx of four to eight sepals that fall early. Fruit: achenes one to ten in each head, ribbed, lanceolate.

A clainty plant, with clelicate foliage closely resembling robust maiden-hair fern. The eye of the traveller is at once caught by its pretty tassels, which hang in clusters and are of a pale green colour, tipped with reddish-purple. It is frequently found along the margins of alpine streams, being much admired in fruit, when it shows numerous seed-bearing stars, tipped with thread-like points.

\section{GLOBE FLOWER}

\section{Trollius laxus. Crowfoot Family}

Stems: weak, ascending. Leaves: palmately divided, the segments many-cleft. Flowers: solitary; sepals five to six, white, with a greenish tinge outside: petals fifteen to twenty-five, bright yellow, minute, much shorter than the numerous stamens.

The Globe filower is one of the most conspicuous of all the carly spring mountain plants that grow at very high altitudes. Close to the borders of alpine lakes and streams, and in marshy places where the snow has recently melted, beds of this beautiful large white fower may be found, its brilliant golden centre gleaming in the sunshine, and its rich, glossy foliage forming a superb setting for its perfect purity.

Do not confuse it with one of the Anemones. Note that its centre is far larger and more golden in hue; also that the foliage is coarser and thicker. There is a bushy circle of leares set on the stalk about one inch below the blossom. The Globe Flower is frequently found growing up through the snow: 
PLATE III

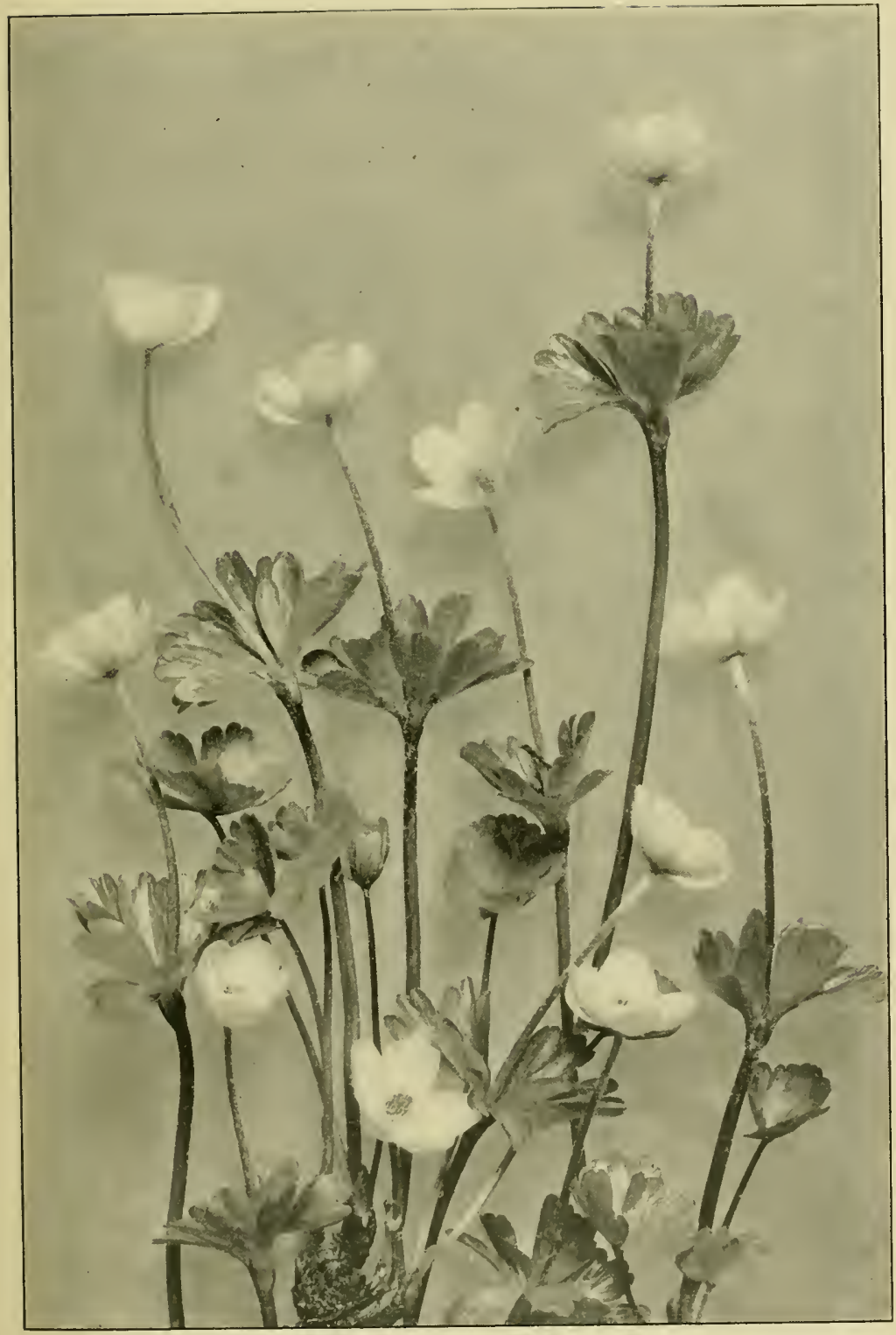

Alpine Anemone

(Anemone Drummondii) 



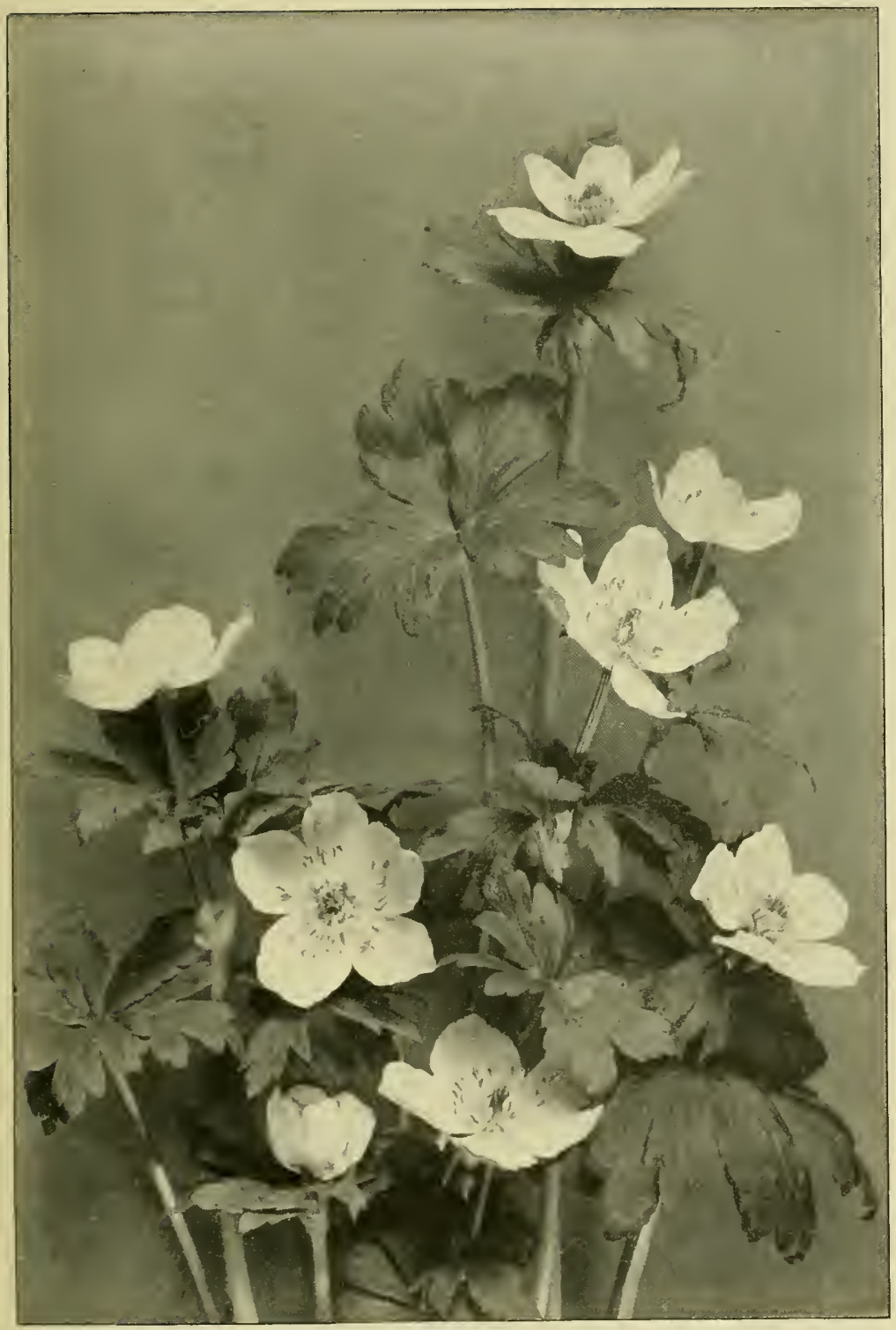

GLOBE Flower

(Trollius laxus) 



\section{WATER-CRESS}

Visturtium officinale. Mustard Family

Aquatic, glabrous: ront fibrous. Stems: stout, hollow, rooting at the decumbent base. Leaves: pinnate, leaflets rounded or elongated, the terminal ones largest. Flowers: petals white; sepals four, early-falling; stamens six; style short, thick. Fruit: pods divaricately spreading, seeds in two rows. Not indigenous.

Surely it is a libel to call this plant Nasturtimm, which signifies "twisted nose," and is given to Water-cress simply because we are supposed to turn up our noses when we eat its acrid leaves. Those who go out to gather flowers will seldom pause to pick this insignificant plant, whose clusters of small white flowers grow close beside, or actually in, the streams and ponds, and whose only claim upon our attention lies in the pleasant pungent flavour of its leaves.

\section{STONY ROCK-CRESS}

\section{Arabis Holbollii. Mustard Family}

Stems: erect, simple. Leaves: spatulate. petioled, entire or sparingly toothed; stem-leaves erect, clasping. Flowers: white or pinkish. Fruit: pods linear, drooping.

Growing out of a cluster of long-shaped leaves, the Stony Rock-cress has a tall stalk, up which many tiny narrow leaves cling. The flowers are small, white, mauve, or pinkish bells, growing in a raceme. This plant, as its name inclicates, is generally found in very dry, stony places. It grows from eight to eighteen inches high, and has very long, narrow seed-pods, which droop downwards.

\section{ALPINE ROCK-CRESS}

\section{Arabis confinis. Mustard Family}

Stems: glaucous, simple or sparingly branched, one to two feet high. Leaves: stellate, pubescent, oborate; stem-leaves sessile, auricled at the base. Fruit: pods narrow, one to two inches long, spreading. 
A plant somewhat resembling $A$. Holbollii, but its flowers are more confined to the top of the stalk. They are usually white.

\section{HAIRY ROCK-CRESS}

Arabis hirsuta. Mustard Family

Stems: erect, nearly simple, rough-hairy. Leaves: in a rosulate cluster, ovate to spatulate, sparsely dentate; stem-leaves partly clasping by a cordate base. Flowers: white, small. Fruit: pods strictly erect, linear.

This plant is easily distinguished from the other Rockcresses by its hairy stalks and leaves.

\section{DRUMMOND'S ROCK-CRESS}

Arabis Drummondii. Mustard Family.

Stems: erect. Leaves: lanceolate, sagittate. Flowers: petals white (seldom pink), twice the length of the sepals. Fruit: pods loosely erect; seeds wing-margined.

A handsome leafy species of Rock-cress, very abundant in some localities. It has erect flat pods.

\section{WHITE WHITLOW-GRASS}

Drabu incume. Mustard Family

Stems: hoary, pubescent. Leaves: oblongr-lanceolate, nearly entire. Flowers: petals notched: style minute. Fruit: pods acute, twisted when ripe, on short erect perlicels.

A plant partaking of the appearance of a weed, and closely resembling a white mustard.

For D). alpina and I). aurea see Yellow to Orange Section.

\section{SHEPHERD'S PURSE}

Capsella liursa-pastoris. Mustard Family

Stems: branching. Leaves: mostly runcinate-pinnatificl, cauline, lanceolate, auricled at hase. Flowers: small, white, in long loose racemes; petals four; sejals four. Fruit: pods cuneate-triangular, truncate abose; seeds ten or twelve in each cell. Not indigenous. 


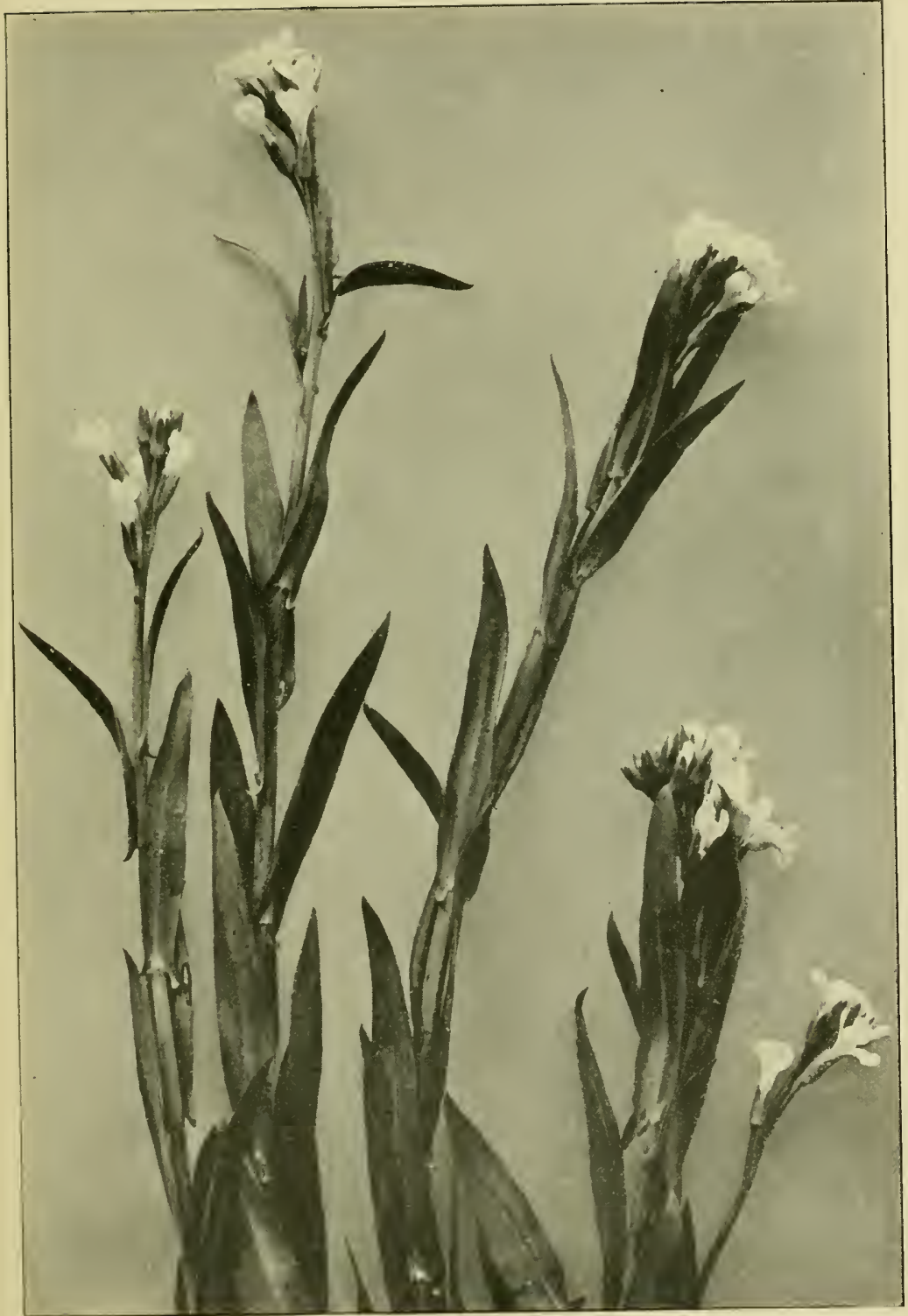

DRUMMOND'S ROCK-CRESS

(Arabis Drummondii) 



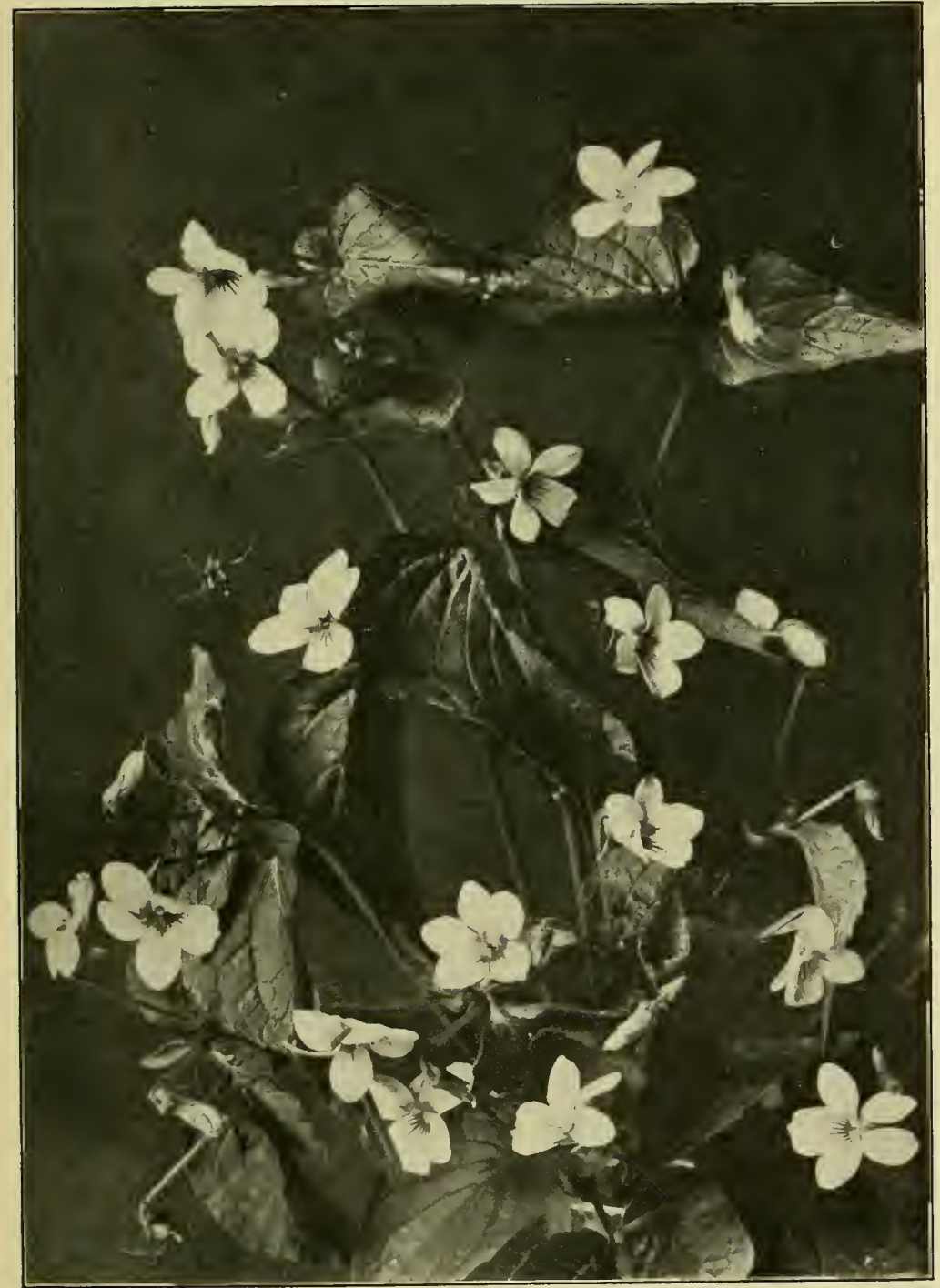

CANAIA VIOLET

(Viola Canadensis) 

This common little white-flowered plant grows all over the world in temperate zones and at various altitudes. Its tiny heart-shaped seed-purses have amused the children of many countries. It is closely related to Candytuft, to which it bears a strong resemblance.

\section{PENNY-CRESS}

Thlaspi aroense. Mustard Family

Stems: erect, glabrous. Leaves: petioled, oblanceolate, dentate; stemleaves oblong. Flowers: white, pedicels spreading or curved upward. Fruit: pods nearly orbicular when ripe, broad, very flat, notched at the apex, in long racemes; seeds rugose. Not indigenous.

Penny-cress very nearly resembles Shepherd's Purse, and the easiest way to distinguish between the two plants is to note that while the seed-pods of the latter are triangular in shape, those of the Penny-cress are nearly round, both being notched at the top. Then, also, the leaves differ: those of the Shepherd's Purse are deeply cut, and those of the Pennycress are only slightly toothed.

\section{CANADA VIOLET}

\section{Viola Canaderusis. Violet Family}

Stems: glabrous, six inches to two feet high. Leaves: cordate, pointed, serrate; stipules entire. Flowers: petals white, tinged and reined with purple, sometimes nearly mauve-pink; spur very short; stigma beakless.

One of the most beautiful of the many violets that grow in the mountains, its lovely white petals, purple-shaded on the back, giving forth a delicate fragrance, and its tall leafy stems bearing aloft many blossoms. Usually it is found in the moist mossy woods, where it flourishes luxuriantly; but it also grows on the open alpine meadows, though here its stalks are not so tall nor its flowers so large as they are in the shade of the pines and firs. The Canada Violet continues to bloom from June until September. 


\section{WHITE CAMPION}

Silene Macounii. Pink Family

Stems: slender, from a branching rootstock, minutely pubescent. Leaves: linear-oblanceolate. Flowers: few, on pedicels; calyx inflated, with short obtuse teeth: petals little exserted, with a broadly-auricled claw, and large, thin quadrate appendages, the flabellate bifid blade with a linear tooth on each sicle.

Like many of the Campions, this one is rery sticky, and is characterized, in common with other members of the Pink Family, by its slender stems being jointed and the leaves set in pairs at the joints. It gives out a faint sweet odour, and is usually found growing among the stones on steep hillsides.

\section{NIGHT-FLOWERING CATCHFLY}

Silene noctiftorc. P'ink Family

Stems: viscid-pubescent, simple or branching. Leaves: obovate, obtuse, narrowed into a broad petiole; upper leaves sessile, orate, acute. Flowers: few, white, in a loose dichotomous panicle: calyx long, tubular, reined, its teeth linear. Not indigenous.

There is little need to describe this plant in detail, since its name alone is sufficient to indicate its chief characteristics. Closed tightly against all invasion during the daytime, and only opening wide its white starry blossoms to the wooing of the soft night wind, this Catchfly sends forth sweetest perfume and lures the crepuscular flies to their doom by first attractiner with its scent and its snowiness, and then entraping with its stickiness those poor cleluded insects that horer over its beauty, enchanted until enchained. Thus does the Catchfly protect its nectar from pilfering insects and preserve it for the butterflies, who, while they sip the sweets, carry the pollen from flower to flower and thereby fertilize the plants. 
PLATE VII

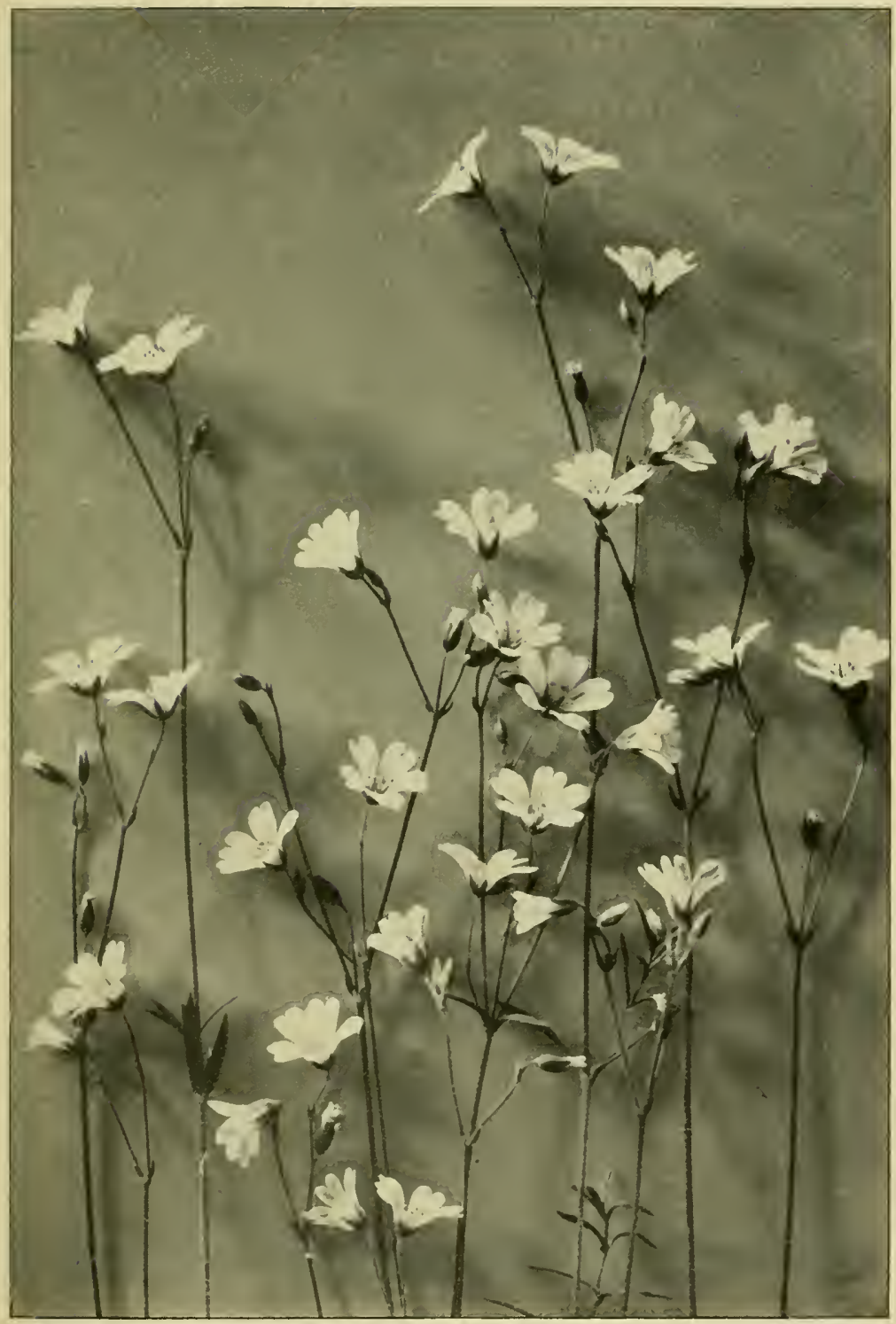

FieLI) CHICKWEED

(Cerastium (yraense) 

PIATE VIII

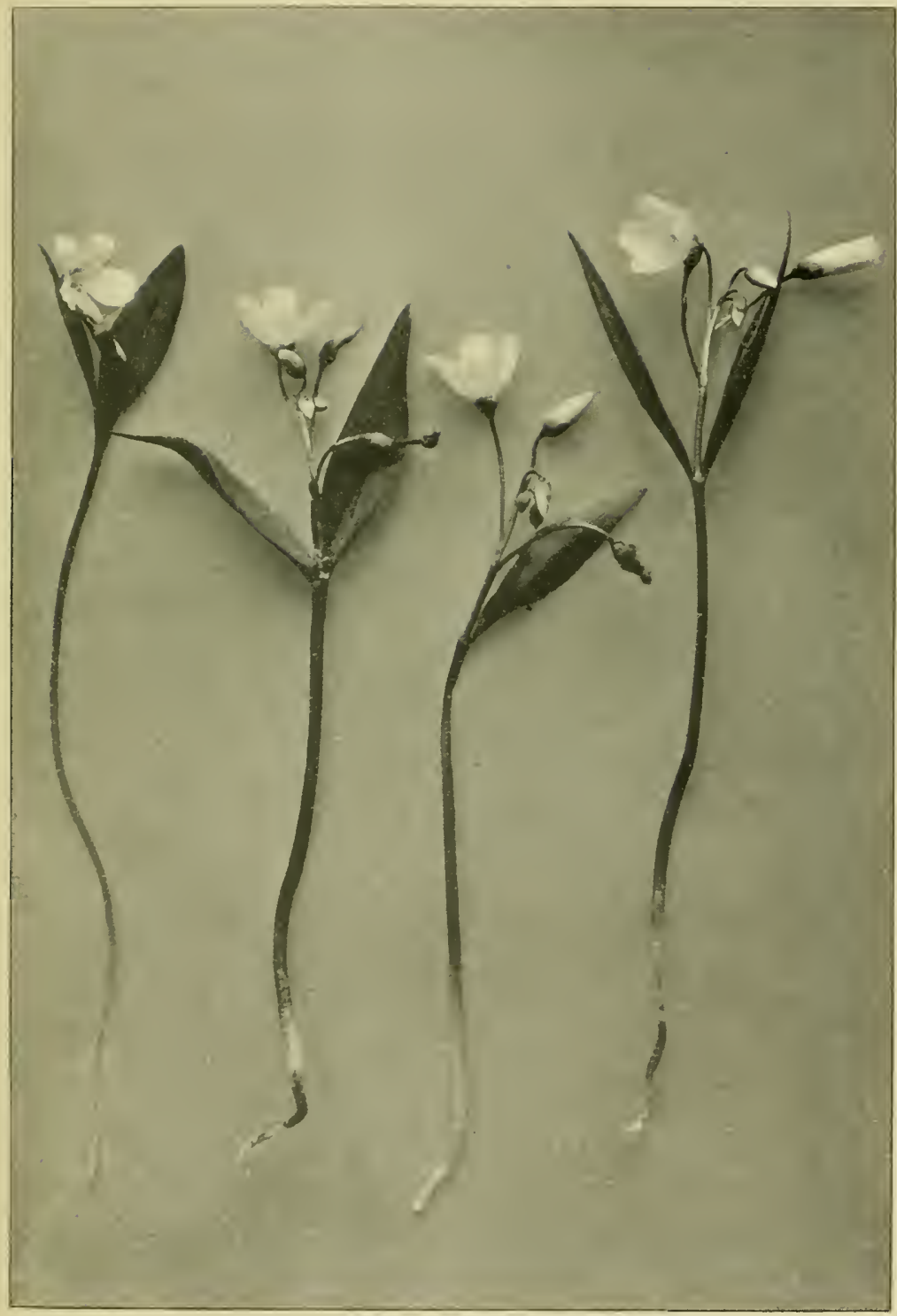

SPRING BEAUTY

(Claytonia sessilifolia) 



\section{ROCK SANDWORT}

Arenaria nardifolia. P'ink Family

Stems: diffusely cespitose, glabrous below, branching from the base. Leaves: slender, rigid, subulate, numerous, fascicled in the axils. Flowers: petals oblong-obovate; sepals ovate, very acute. Fruit: capsule as long as the calyx.

A tiny plant with white starry blossoms that finds a home in crevices of the rocks at extremely high altitudes. There are many different species of Sandwort in all mountain regions, and some of them, such as A. biflora, or Arctic Sandwort, have been found 9000 feet above sea level; but they are insignificant plants, and only attract passing attention when seen near the snow-line, where vegetation is so sparse that even the smallest flower is welcomed with avidity.

\section{STICHWORT}

Stellaria longipes. I'ink Family

Stems: smooth. Leaves: ascending, linear-lanceolate. Flowers: few, on long slender pedicels; petals two-cleft; sepals ovate. Fruit: capsule ovoid. Seeds smooth.

A pretty little flower, with whitish-green leaves, very pointed at the ends.

\section{FIELD CHICKWEED}

\section{Cerastium arvense. l'ink Family}

Stems: erect, pubescent with reflexed hairs, cespitose, four to eight inches high. Leaves: linear-oblong, acute, clasping; bracts small. Flowers: cymose, few-flowered; petals five, obcorclate.

This is quite the prettiest and most attractive of all the Chickweeds, and will be found growing in profusion on many a sunny bank and dry meadow during the months of June and July. It is frequently called "Star of Bethlehem," and 
has five snow-white petals, each of which is divided at the edge. All the Chickweeds are white, and among those that are specially prolific in mountain regions may be mentioned C. alpinum sar: Bchringianum, or Alpine Chickweed, a silkyhaired species, with whitish leaves.

\section{SPRING BEAUTY}

Claytonia sessilifolia. Purslane Family

Stems: weak, from a tuber. Leaves: few, opposite, oblong. Flowers: in a loose raceme on slender pedicels, nodding, white or pale pink: veins rose; calyx of two ovate sepals; petals five; style three-cleft at apex.

Close to the snow, in warm wet valleys, when the June sunshine has awakened the alpine world from its winter sleep. you will find the Spring Beauty, and as you stoop to gather it the whole plant (consisting of a tuberous root and one stalk with two leaves upon it and a cluster of blossoms at the top) will inevitably come up in your hand, so easily does it leave the ground. No sooner does this happen than the petals begin to close, the leaves to droop, and the stem to grow limp. Ten minutes afterwards the flower is hopelessly wilted. Whether white or clelicate pink, the Spring Beauty is always reined with bright rose colour. There are few more exquisite wild blossoms on this continent than

"These little dream-flowers found in Spring,"

of which Longfellow wrote in "Hiawatha" :

"Where the fire had smoked and smouldered, Saw the earliest flower of Spring-time, Saw the Beauty of the Spring-time, Saw the Miskodeed in blossom."

Miskodeed is the Inclian nane for the Spring Beauty. 


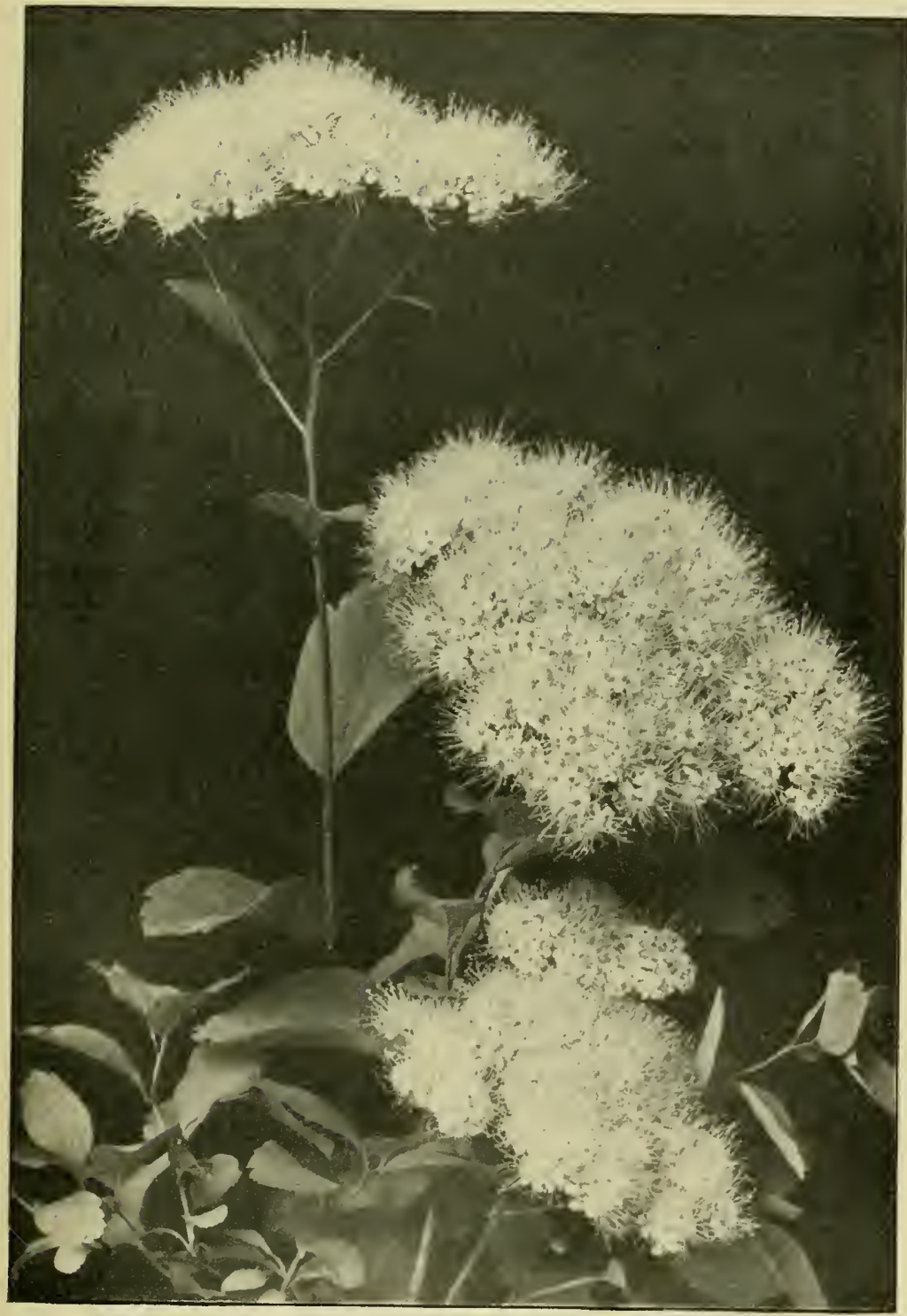

BIRCH-LEAVED SPIRA:A

(Spirrea lucida) 



\section{WHITE GERANIUM}

Geranium Richardsoni. Geranium Family

Stems : erect with slender branches, one to three feet high. Leaves : deeply five-to-seven-cleft, lobes sharply incised. Flowers: petals entire, hirsute at base; sepals glandular, pilose.

This Geranium is almost invariably white, but very occasionally it is purple-red. The plant is a handsome one, tall, with rich foliage and fine flowers.

\section{WHITE CLOVER}

\section{Trifolium repens. Pea Family}

Perennial, branching at the base, rooting at the nodes. Leaves: longpetioled; stipules narrow, lanceolate; leaflets obcordate, denticulate. Flowers: white or pinkish, in loose, globose long-peduncled heads; calyx teeth acuminate. Fruit: pods four-seeded. Not indigenous.

This Common or Ioneysuckle Clover is widely clistributed. It may be quickly recognized by the fact that the leaves all grow on long stalks directly from the root, whereas the other white species, T. hybridum, or Alsatian Clover, is much taller and has numerous leaves growing up on its flowerstalks. The latter species is frequently pinkish in hue.

Clovers have a very close association with our childhood, those happy bygone days when we plucked out single flowers from the rounded heads and sucked the slender tubes of nectar; and always the sweet scent of the Clover blossoms recalls to us the well-remembered fields where

"South winds jostle them,

Bumble-bees come,

Hover, hesitate,

Drink, and are gone." 


\section{INDIAN VETCH}

Astragalus aboriginorum. Pea Family

Stems: finely glabrate, erect, branched. Leaves: leaflets linear, obtuse : stipules ovate, acute, foliaceous. Flowers: white, tinged with mauve in loose racemes; ped uncles longer than the leaves; calyx blackish-pubescent, its teeth subulate. Fruit: pods semi-elliptic.

One of the least attractive of the Vetches. It has a long yellow root which is collected in the spring by the Stoney and Cree Indians as an article of food. The leaves are whitish and rather silky, and the flowers are chiefly noticeable by reason of their dark-hued hairy calyx.

\section{ARCTIC VETCH}

\section{Phaca Americana. Pea Family}

Stems: erect, nearly simple, tall, leafy, subglabrous. Leaves: leaflets seven-to-nine paired, ovate, and elliptic-oblong; peduncles equalling the leaves. Flowers: white, in a loose raceme. Fruit: pods oblong, acute at each end, black-hairy:

A handsome plant, growing one to two feet high, with many leaves, and big white-flowered heads. It has no tenchrils, but grows very stiffly with thick upright stalks.

\section{WHITE VETCH}

\section{Lathyrus ochroleucus. P'ea Family}

Stems: slender, trailing. Leaves: leaflets in three to four pairs, ovate, distinctly petioled; stipules semi-cordate, entire. Flowers: seven-to-ten tlowered, ochroleucus; tendrils branched. Fruit: pods oblongr-linear, sessile, grabrous.

No one wandering in the summer woods can mistake this dainty, delicate White Vetch, which trails along the ground, climbs over fallen trees, and twines its tiny branching tendrils about the shrubs besicle which it grows. The flowers resemble those of the common garden green pea. 


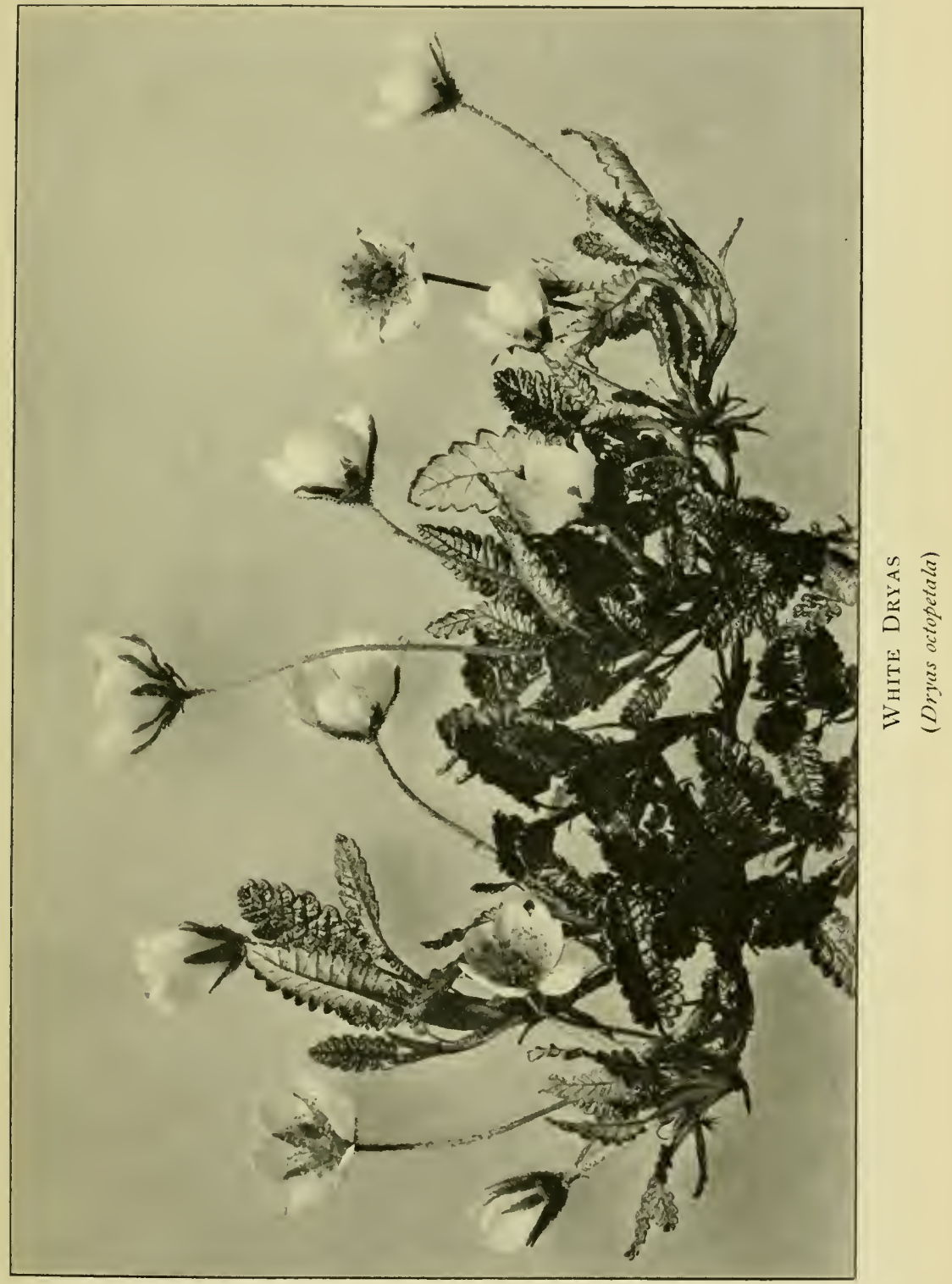




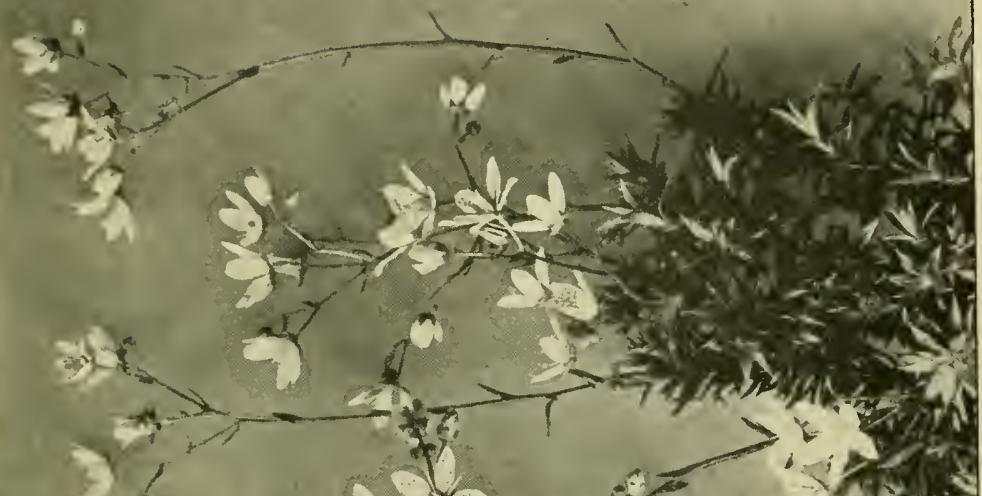

?

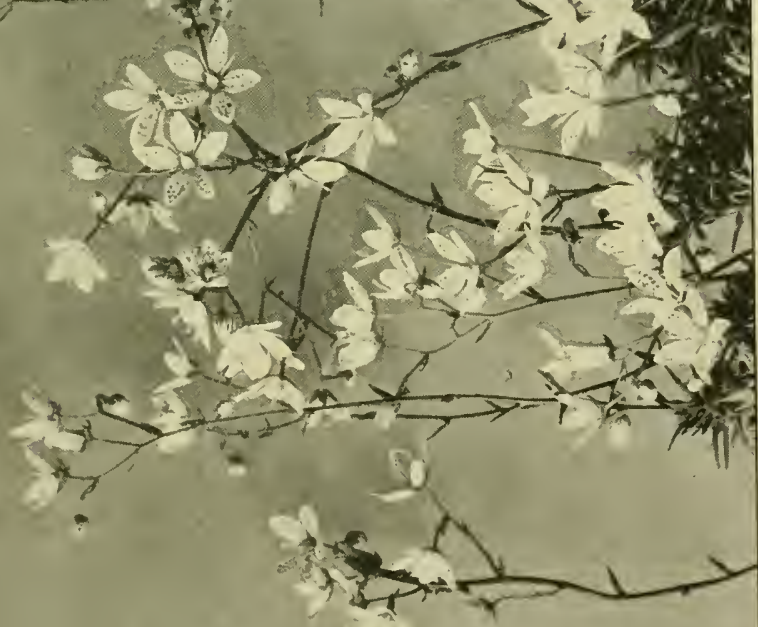

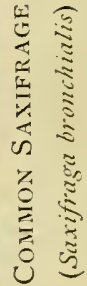





\section{WHITE HEDYSARUM}

Hedysarum boreale z'ar. albiflorum. Pea Family

This is a white species of $H$. borcale, a full description of which will be found in the Blue to Purple Section.

\section{BIRCH-LEAVED SPIR EA}

\section{Spirca lucida. Rose Family}

Stems: erect, reddish, woody, one to two feet high. Leaves: lower ones small, obovate; upper ones oval, acutish, unequally serrate on short petioles. Flowers: cream-colour in compound corymbs; petals five, rounded.

A small bushy shrub with woody stems bearing large showy, fluffy flower-heads, flattened on the top and formed of numerous tiny cream-coloured blossoms tinged with pink.

It frequently grows by the side of mountain roads and at the edge of trails, where the bright sunshine brings it out to perfection. The red woody stems break off with a sharp snap, and the scent of the flowers is extremely sweet.

This Spirca is really a flowering shrub, but is placed in this Section for greater convenience, as it is here that most travellers will look for it.

\section{ALPINE SPIR EA}

Spiraa pectinata. Rose Family'

Stems: cespitose, creeping, very leafy; flowering stems erect. Leaves: trifoliolate, persistent; leaflets deeply lobed. Flowers: in short terminal racemes; calyx-lobes ovate, acute, equalling the tube; petals obovate.

A lovely trailing plant, its flowers growing to an average height of four inches, in elongated heads, each individual tiny blossom having six white petals and a number of yellow stamens. The leaves grow close to the ground, resembling a large moss, and are deeply fringed and fern-like. The shoots of the plant run along the ground; the stems of the flowers are brittle and woody. 


\section{CREEPING RASPBERRY}

Rubus pedatus. Rose Family

Stems: trailing, filiform, rooting at the nodes, pubescent. Leaves: trifoliolate; leaflets cuneate-obovate, incised, serrate. Flowers: solitary on long slender pedicels: sepals nearly glabrous, entire, exceeding the petals. Fruit: large red juicy drupelets.

A charming little vine that trails over the rocks and creeps along the ground, gemming the moss with its starry fivepetalled white flowers, in the centre of each of which grow many fine yellow-tipped stamens. The leaves are divided into three (or very rarely five) leaflets, which are coarsely toothed at the edges. The fruit consists of a cluster of from three to six red juicy globules, pressed together and held in a cup of tiny green leaves. The long lithe strands of this pretty, delicate vine are most decorative, as many white flowers and scarlet fruits may be gathered at the same time upon a single trailing branch.

\section{WHITE DRYAS}

Dryas octopetala. Rose Family

Stems: prostrate, woody at the base, branched. Leaves: oblong-ovate, coarsely crenate-toothed, obtuse at each end, green and glabrous above, densely white-canescent beneath, the veins prominent. Flowers: white. Fruit: plumose, conspicuous.

These beautiful white-cupped flowers grow close to the ground, generally in dry sandy or rocky places. They do not always have eight petals, as their name would indicate, but may be found with from six to twelve on a single flower. The name Dryess is from the Latin, signifying "a woodnymph," and certainly the velvety petals of this dainty plant, growing amid a mass of silver-backed leaves, are sufficiently exquisite to warrant the appellation. 
PLATE XII

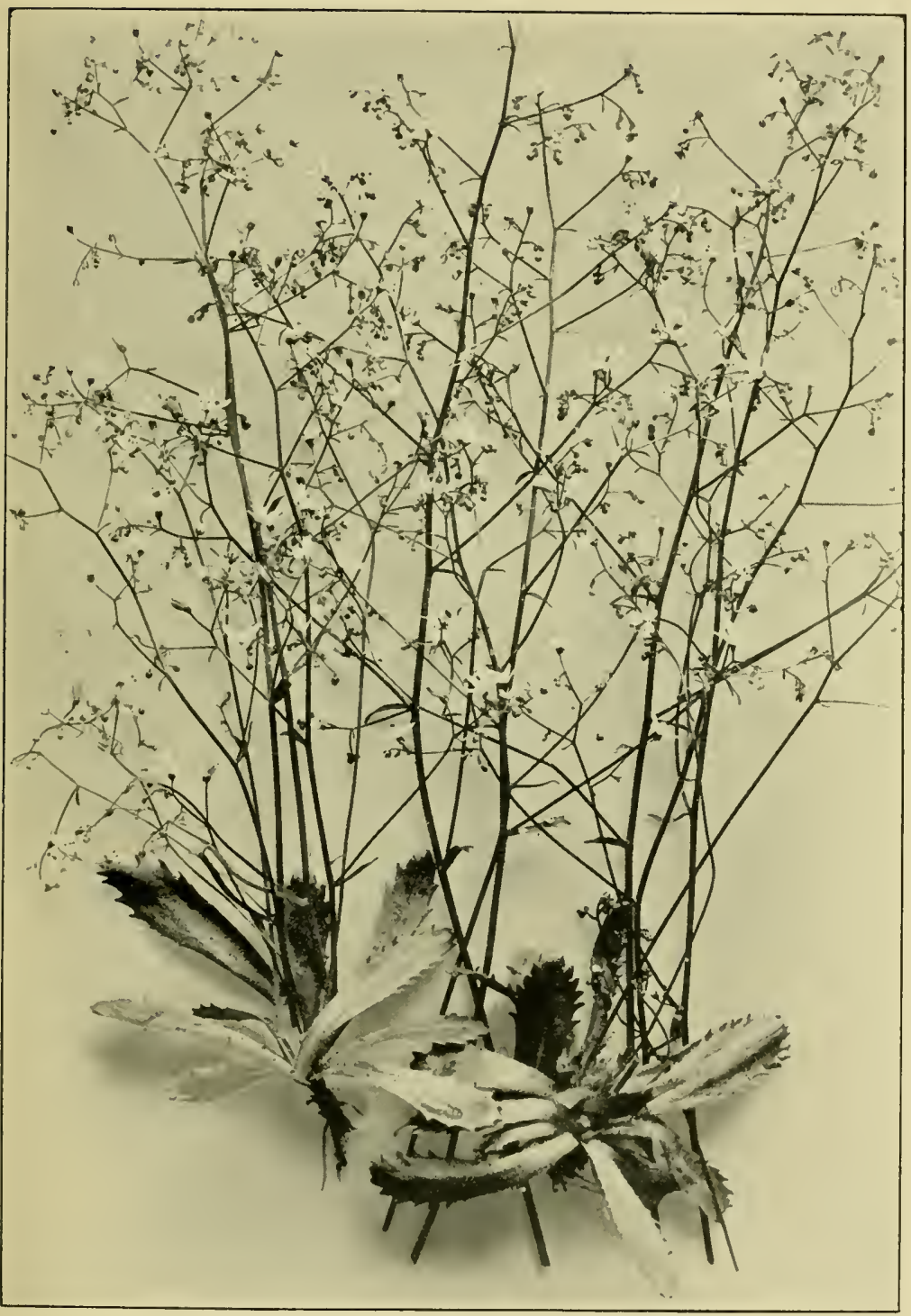

TALL SAXIFRAGE

(Saxifraga Nutkana) 



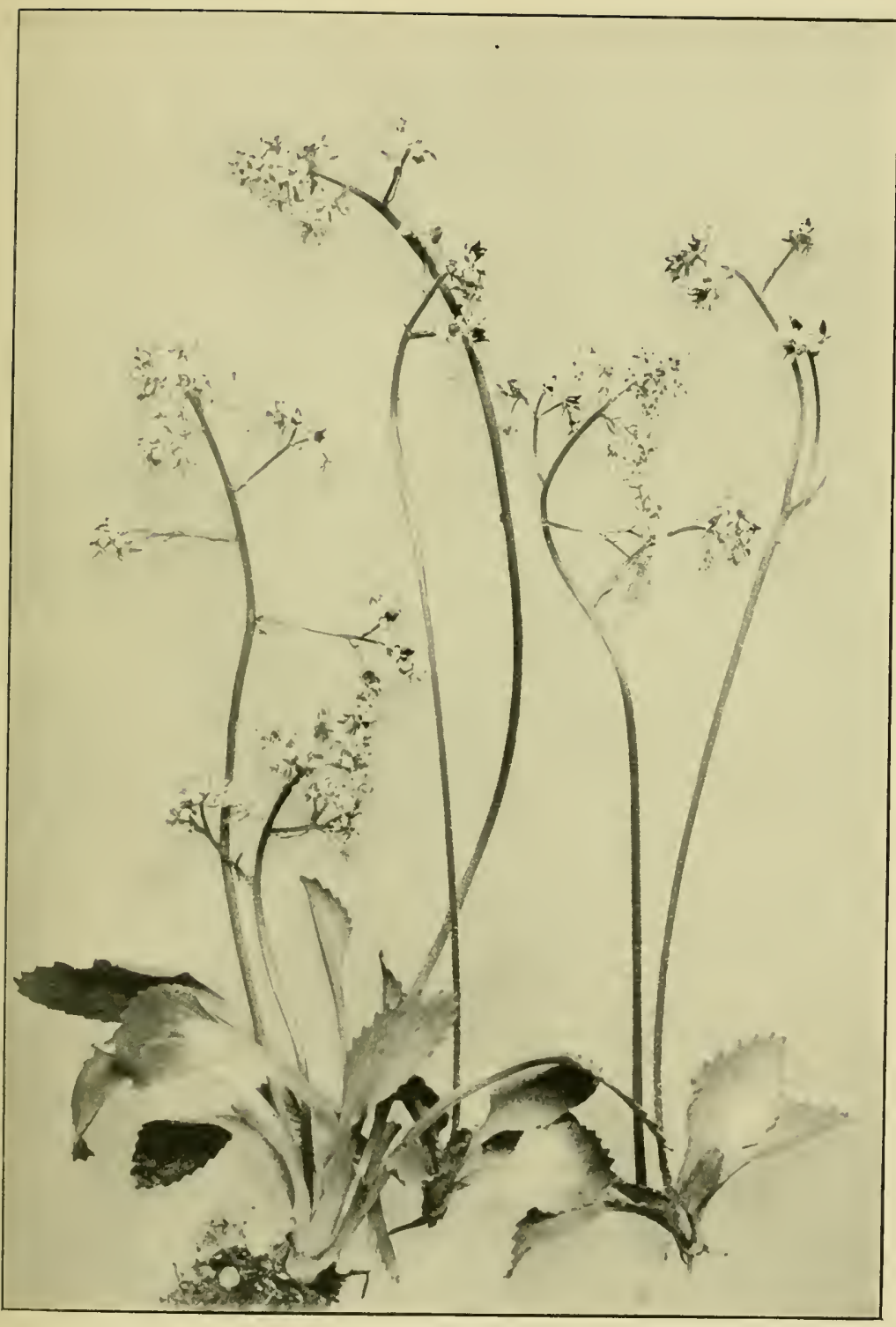

Alpine Saxifrage

(Saxifraga nivalis) 



\section{WILD STRAWBERRY}

\section{Fragaria glauca. Rose Family}

Stems : running, and forming new plants. Leaves: tufted from the root, villous-pubescent with spreading hairs, long-petioled, palmately-trifoliate; leaflets oval, obtuse, dentate, the terminal one cuneate. Flowers: of five petals, cymose: scape with appressed pubescens and generally glaucous leaves. Fruit: red, ovoid.

Nearly every one will easily recognize the blossoms of the Wild Strawberry plant. "Doubtless God could have made a better berry, but doubtless God never did." This is equally true of the fragrant scarlet fruits on the mountain side as of their cultivated cousins in the garden.

\section{TALL CINQUEFOIL}

\section{Potentilla arguta. Rose Family}

Stems: erect, stout, simple below. Leaves: seven-to-eleven foliolate; leaflets ovate, obtuse at the apex, - the terminal one cuneate, the others rounded at the base. Flowers: cyme strict, close; calyx densely pubescent.

Cinquefoils are very numerous in the mountain regions, and somewhat resemble buttercups. The Tall Cinquefoil is a fine showy plant, its white flowers growing in a cluster and having five petals; the stalks are hairy and have many leaves growing up them. See also page 276 in the Yellow to Orange Section.

\section{COMMON SAXIFRAGE}

\section{Saxifraga hronchialis. Saxifrage Family}

Stems: one to six inches high, ascending, slender, producing short branchlets. Leaves: coriaceous, lanceolate, mucronate, sessile, with a broad base finely ciliate. Flowers: few, in an open corymb on slender pedicels; petals oblong, white, marked with red spots.

Frequently the traveller will find immense rocky slopes literally covered with the pretty little blossoms of this Saxifrage, which may easily be recognized by the bright red spots 
that mark its five white petals. It is a low-growing species, the flower-stalks seldom exceeding six inches in height, and being much branched and reddish in colour. The tiny narrow leaves are very stiff, - indeed, a noticeable characteristic of the whole plant is its rigid nature. The name is derived from sar.rum, "a rock," and frougo, "I break," and the Germans call it Stcinbrch, because it grows so thickly in the crevices of the rocks that it is supposed to disintegrate them by its growth. All the Saxifrages are much visited by flies and bees, and

"Scarce less the cleft-born wild-flower seem.s to enjoy

Existence, than the winged plunderer

That sucks its sweets."

\section{NODDING SAXIFRAGE}

Saxifraga cemua. Saxifrage Family

Stems: tall, slencler, glutinous. Leaves: alternate, basal ones petioled, broadly reniform, palmately five-to-seven lobed; upper leaves smaller, entire, sessile, bract-like, with small red bulblets in their axils. Flowers: terminal, noddling.

A creamy-white flower, more rare than many of its sister Saxifrages, and growing from four to eight inches high. The traveller will at once be struck by the little bright red bulbs that grow in the axils, where each upper leaf is attached to the stalk; and by this characteristic, as well as by its lower palm-like leaves, the Nodding Saxifrage may be readily known. It grows among the rocks at very high altitudes.

\section{LYALL'S SAXIFRAGE}

Saxifiaga Lyallii. Saxifrage Framily.

Stems: crlabrous, caudex creeping, sparingly branched. Leaves: obovate, attenuate below to a margined petiole, coarsely tonthed at the summit. Flowers: numerous; calyx parted to the base: petals round-obovate: filaments flat. Fruit: capsule united only at hase; beaks red, erect. 


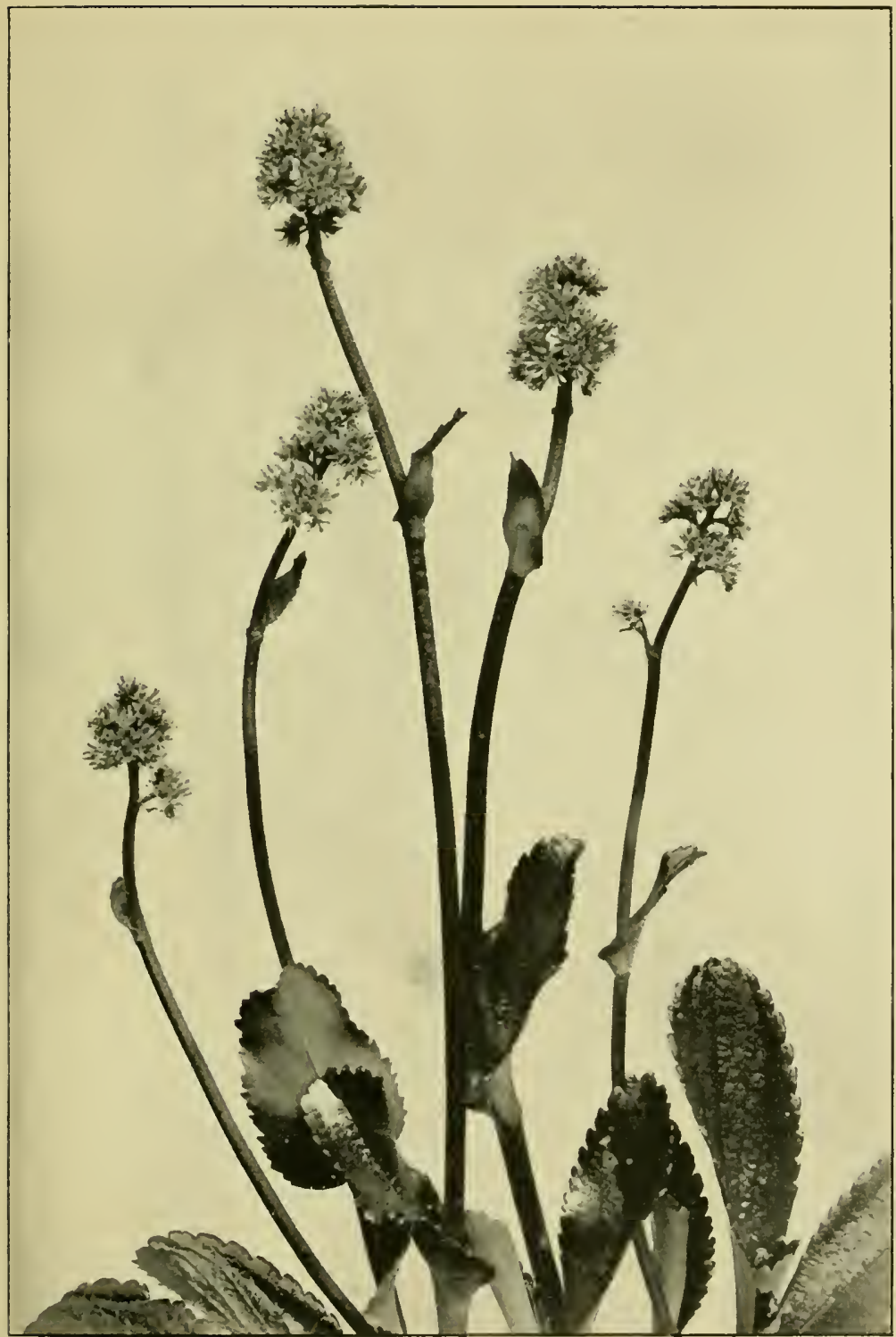

LEPTARRHENA

(Lepharrhena fyrolifolia) 



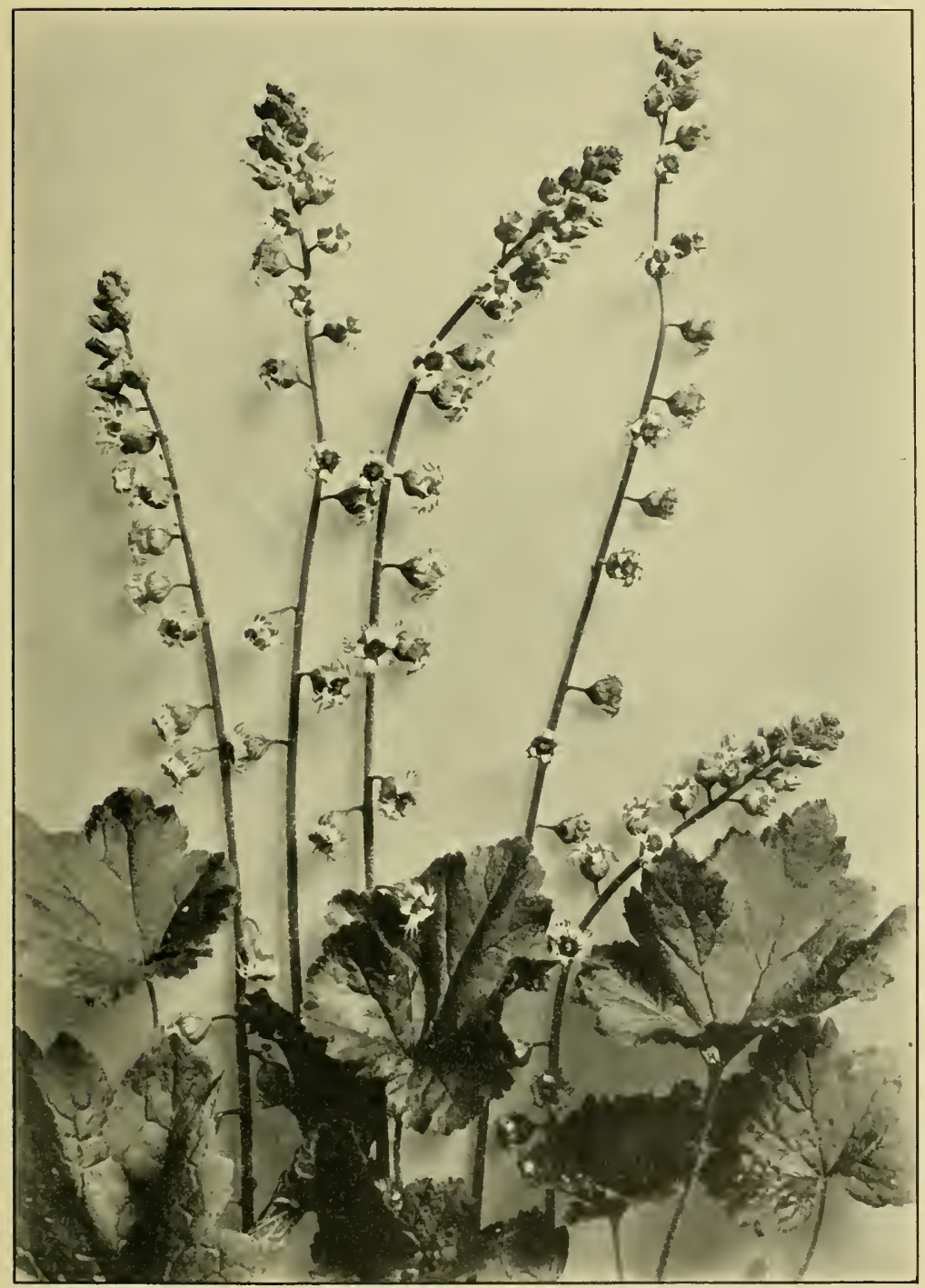

TELLIMA

(Tellima grandiflora) 

There are two tall very branching white Saxifrages which to the ordinary eye closely resemble one another, namely, Lyall's Saxifrage and Tall Saxifrage, and a careful reference to the descriptions of each should be made in determining a particular plant.

Lyall's Saxifrage is the smaller of the two plants, and is less branching; its leaves grow in a cluster at the base, are rounded, deeply toothed, and of ten tinged and streaked with red. The flowers, which are very numerous, are white. A special distinguishing feature is the seed-pods, three or four in number, which develop in the centre of each flower in a cluster, and are red, with very pointed beaks.

\section{TALL SAXIFRAGE}

Saxifragra l'utkana. Saxifrage Family

Stems: tall, erect from a fleshy caudex, paniculately branched above. Leaves: cuneate, spatulate, attenuate to a broad petiole, coarsely dentate above the middle. Flowers: numerous, in a loose secund panicle: petals five, white, with a red spot at base of blade; filaments clavate as long as the petals. Fruit: beaks red, erect.

The Tall Saxifrage is a larger and handsomer plant than Lyall's variety. It is also more branching, growing from six to eighteen inches high, and covered with many tiny white blossoms, each with a bright orange or red spot at the base of the blade. The leaves grow in a cluster at the base, from the centre of which the flower-stalks spring; they are hairy, long-shaped, and sharply toothed. You can best distinguish the Tall Saxifrage from Lyall's species by the leaves, which in the former are spatulate and long-shaped and in the latter rounded. The Tall Saxifrage also generally has small bulblets growing below the flowers. 


\section{ALPINE SAXIFRAGE}

Saxifraga nizalis. Saxifrage Family

Stems: six inches high, viscid-pubescent, with few or no bracts. Leaves: ovate, narrowed into a margined petiole. Flowers: white, in a compact cluster. Fruit: follicles divergent, purple-red.

A plant which grows at extremely high altitudes, as well as on the lower mountain slopes. It, too, has a cluster of leaves at the base, rounded and toothed at the top and narrowing down sharply towards the root. The flowers grow in handsome compact heads, and the stalks, usually quite bare of leaves, are reddish and not straight. The seed-pods are purple-red and spreading.

\section{LEPTARRHENA}

\section{Leptarthona pyrolifolia. Saxifrage Family}

Stems: six to fifteen inches high, rigid, with one or two small leaves with sheathing petioles. Leaves: obovate, coarsely serrate above the middle, attenuate below to a short-winged petiole, which is dilated and sheathing at the base. Flowers: numerous, in bracted paniculate racemes: petals five, entire, linear, white ; calyx campanulate. Fruit: carpels purplered, divergent.

A very handsome plant, with closely clustered flower-heads and thick glossy leaves. In seed it is remarkable for its rich purple-red appearance. It grows in quantities near many alpine streams.

\section{TELLIMA}

\section{Tellima grandiflora. Saxifrage Family}

Stems: hispid-pubescent, from short tufted rootstocks. Leaves: roundcordate, three-to-nine lobed, coarsely tonthed, on long petioles. Flowers: cream-colour, with rose-pink margins, on very short reflexed perlicels; calyx thick, cylindraceous, with turbinate tube and short, triangular, erect lolses, inflaterl; petals laciniately cut into filiform segments, narrowed below to a short claw. 


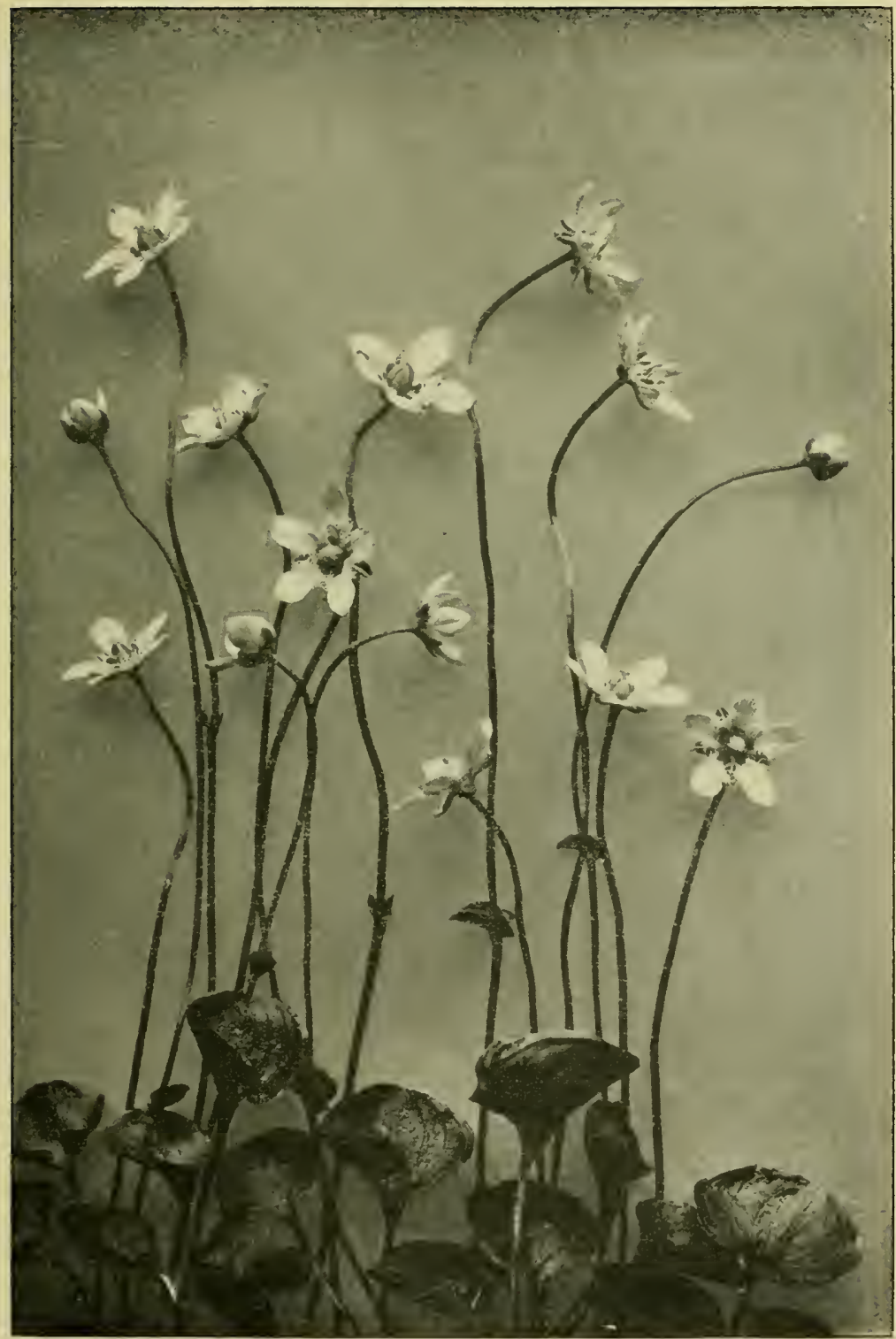

Marsh Grass of PARNassus (Parnassia montanensis) Fringed Grass of ParNassus (Parnassia fimbriata) 

PLATE XVII

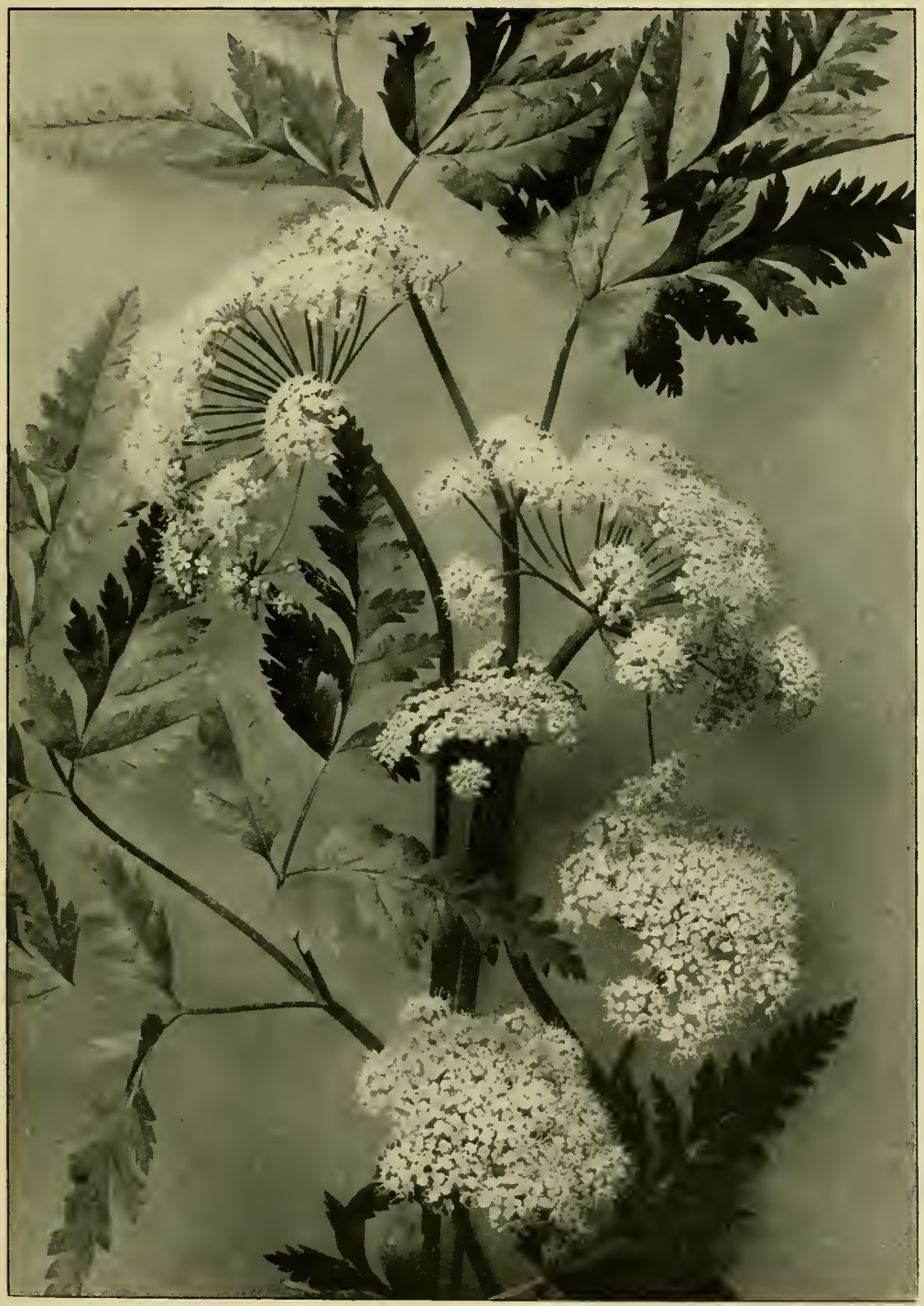

WILI PARSLEY

(Ligusticum apiifolium) 

A plant that is easily recognized by means of its long stalks, bearing numerous round cream-coloured or green blossoms, which are set closely against it, their edges rose colour and deeply fringed. It grows from one to two feet high and has quantities of foliage, the leaves being large, rounded, and lobed, with fine white hairs standing up all over them.

\section{FALSE MITRE-WORT}

Tiarella unifoliata. Saxifrage Family

Stems: slender, spreading from running rootstocks. Leaves: simple, cordate, acute, obscurely five-to-seven lobed on long fine petioles. Flowers: numerous, in a narrow panicle; calyx cleft to near the base; petals five, filiform; stamens ten.

The tiny feathery flowers of the False Mitre-wort are found in great quantities in the mountains. Their large heartshaped leaves appear to carpet the ground about three inches above the soil in the localities where they abound, and their great white masses of delicate bloom have earned for them the name of "Foam-Flower." The Latin name Tiarella means "a little tiara," and refers to the shape of the capsule, while unifoliata refers to the one leaf on the flower-stalk.

\section{TRUE MITRE-WORT}

\section{Mitella Breweri. Saxifrage Family}

Stems: pubescent with brownish hairs. Leaves: round-cordate, three-tofive lobed, toothed. Flowers: small, green, in simple spicate racemes; calyx short, campanulate; petals pectinately pinnate, with filiform pinnza.

The True Mitre-wort is one of the few absolutely green flowers that grow in the mountains; it derives its name of Mitella, or Bishop's Cap, from the form of the seed-pod. It differs from the False Mitre-wort, first, in that its blossoms are much more fragile and green, and secondly, in that it is more leafy and is covered with tiny hairs. 


\section{ALUM-R0OT}

Heuchera oralifolia. Saxifrage Family

Stems: six to eighteen inches high, leafless. Leaves: ovate, cordate, crenate. Flowers: greenish-cream, small, in terminal panicles, spike-like, cylindrical, two to four inches long; calyx campanulate; petals filiform or none. Fruit: seeds hispid.

This plant is usually found in very dry stony places, among the rocks or on gravelly slopes. It is remarkable for its tall stiff stalks, which are leafless and end in a dense spike of closely-set creamy flowers. The leaves are green and reddish, round, and with way margins. It is a peculiar but not an attractive plant.

\section{MARSH GRASS OF PARNASSUS}

\section{P'arnassia montanensis. Saxifrage Family}

Stems: bearing one clasping ovate leaf. Leaves: ovate, petioled, obtuse at the apex, cordate at the base. Flowers: elliptic, few-veined; petals five ; stamens numerous, in clusters at the base of each petal.

Why "Grass," and why "of Parnassus"? Assuredly the traveller will be surprised when he finds what kind of flower bears this exceedingly unsuitable name, for the Grass of Parnassus is like a delicate white buttercup, the veins in its petals being strongly marked, and numerous stamens growing at the base of every blade. Each stalk is clasped by a single little round leaf, and a mass of smooth glossy foliage grows close to the ground. These basal leaves are much curled up, and in low-lying marshes and other wet places you will find them in profusion during the month of July. Perhaps it was the relvety petals of the Grass of Parnassus that caused Emerson to ask:

"Why Nature loves the number five, And why the star-form she repeats?" 


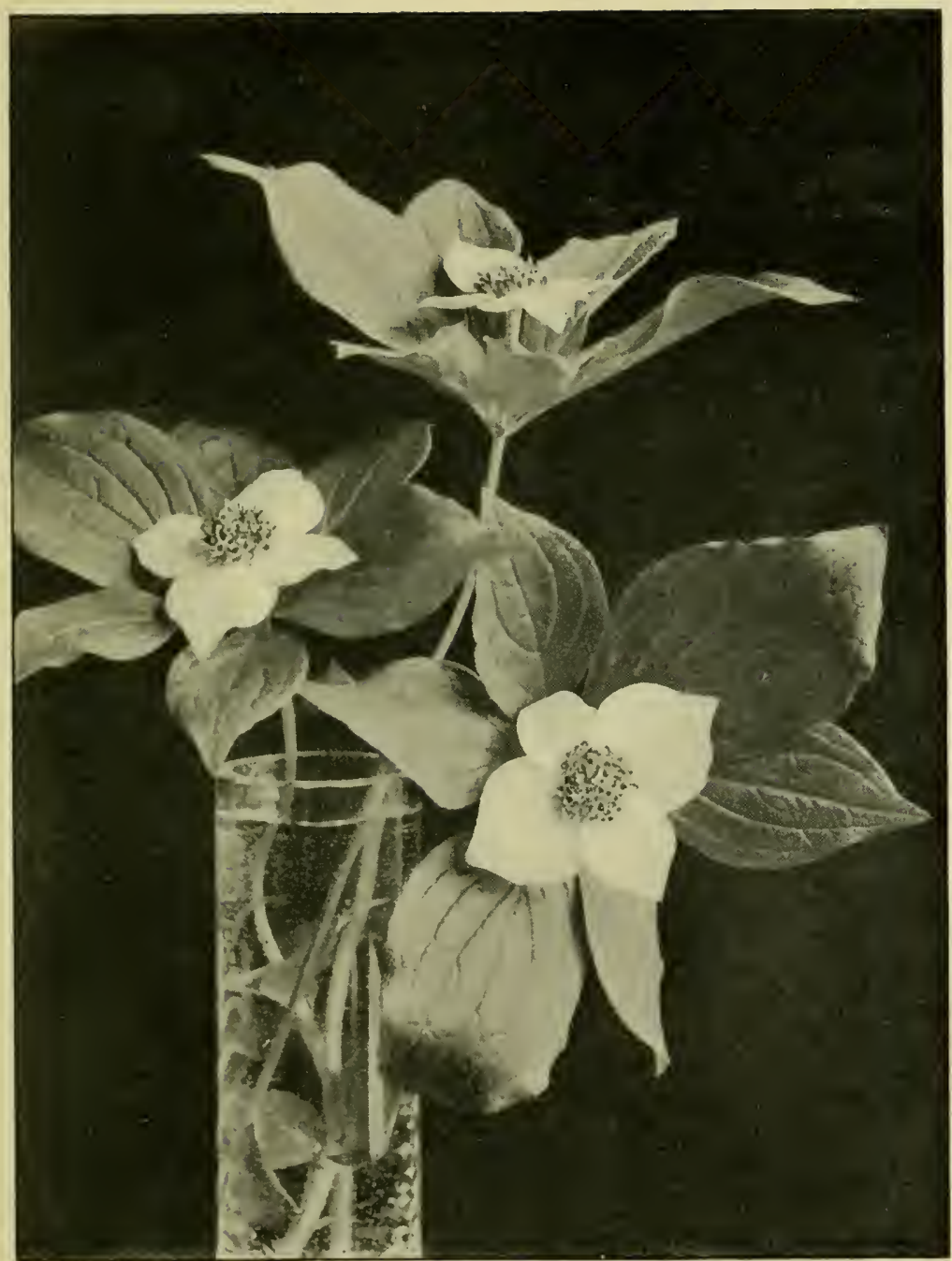

BUNCH-BERRY

(Cormus Canadensis) 


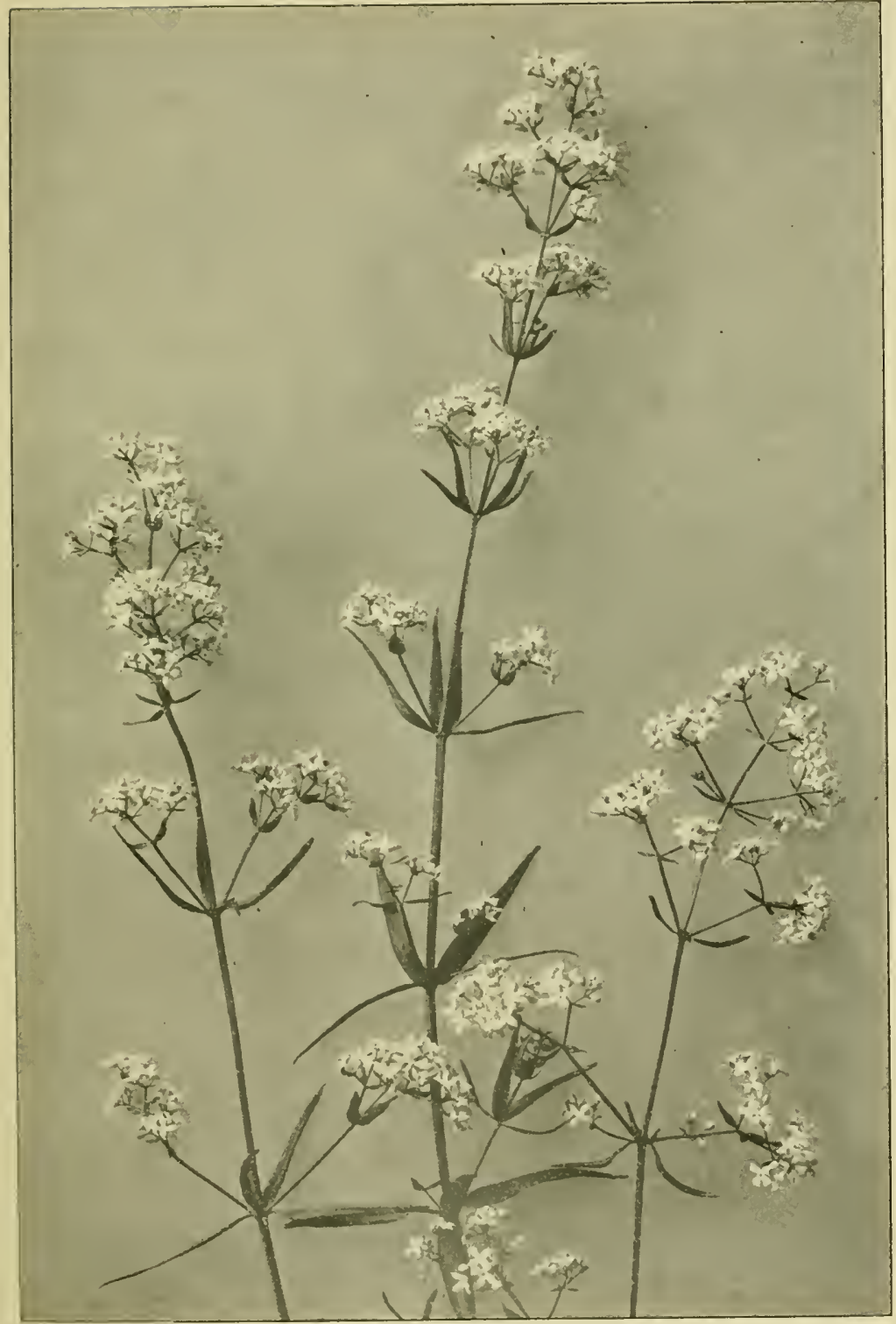

NORTHERN BEISTTRAW

(Gulium bereale) 

For in this particular mountain wild flower the five petals and the star-form are both especially conspicuous.

Another species of this genus is $P$. fimbriata, or Fringed Grass of Parnassus, also very common in moist places among the mountains. It closely resembles the plant already clescribed, but may be clearly distingtished from it, because the petals are conspicuously fringed towards the base and have fine marginal hairs.

P. Kotzebuci, or Alpine Grass of Parnassus, is a tiny species, only a few inches high, and is found at great altitudes.

\section{WILD PARSLEY}

\section{Ligusticum apiifolium. Parsley Family}

Roots large, aromatic. Stems: thick. Leaves: radical, ternate, or biternate, then once or twice pinnate, the segments ovate, laciniately pinnatifid. Flowers: in umbels of numerous rays, with involucre of linear bracts; calyx-lobes obsolete.

A beautiful plant, having fine white flower-heads and decorative fern-like foliage.

\section{COW-PARSNIP}

\section{Heracleum lanatum. Parsley Family}

Stems: very stout, tomentose-pubescent, rigid. Leaves: petioled, ternately divided, the segments broadly ovate, cordate, stalked, lobed and sharply serrate; petioles much inflated. Flowers: umbels many-rayed.

Hcraclcum, from the Greek name of Hercules, is an excellent designation for this huge Cow-Parsnip, which among plants is certainly a veritable hero for strength and size, frequently growing to a height of eight feet. Its huge leaves and great clusters of white flowers, often measuring a foot across, are very showy, and once seen will always be remembered. The plant has an extremely nasty smell. 


\section{BUNCH-BERRY}

\section{Cornus Canadensis. Dogwood Family}

Stems. erect. Leaves: verticillate at the summit of the stem, sessile, oval, pinnately reined, acute at each end, entire; bracts involucral, white. Flowers: greenish, capitate. Fruit: red, globose.

A slender tough stem bearing a circle of four or five oval, pointed leaves at its summit, out of the midst of which grows a cluster of inconspicuous tiny green flowers, surrounded by four beautiful white bracts, - such is the Bunch-berry, or Pigeon-berry, which we find everywhere in the forests. It will surprise many travellers to learn that the lovely white leaves are not the petals, but only the bracts encircling the wee green flowers in the centre.

When these white bracts have fallen off, each flower-head develops into a bunch of small scarlet berries, from which the species derives its common name.

\section{NORTHERN BEDSTRAW}

\section{Galium boreale. Madder Family}

Stems: smooth, branched, leafy. Leaves: in fours, linear, acute. Flowers: in terminal panicles, dense, many-flowered in small compact cymes. Fruit: hispid.

The Northern Bedstraw may be distinguished by the fact that its tiny narrow leaves grow in circles of four round the stems. It is a plant bearingr many small white flowers in clusters, and the seeds are twin burs, covered with numerous hooked bristles, by means of which they cling to the clothing of the passer-by and the fur of animals.

Sir John Franklin in his book The I'oler . Sers describes this plant as being used by the Indians as a vegetable dye. They call it Sarvojern, and after boiling the roots they mix the liquid with the juice of strawberries and cranberries, and thus obtain a beautiful scarlet dye. 


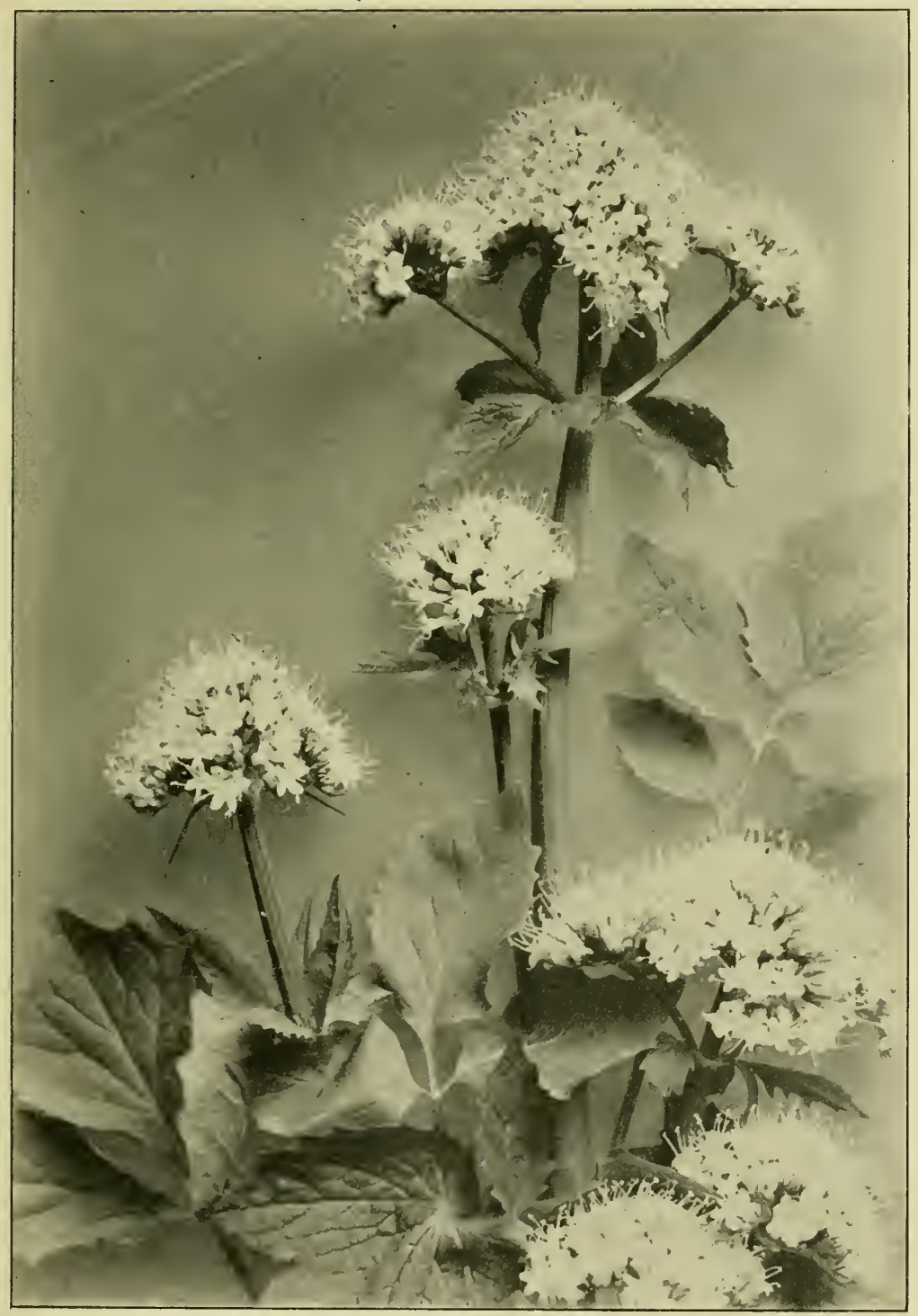

Winte Heliotrope

(Valeriana sitchensis) 



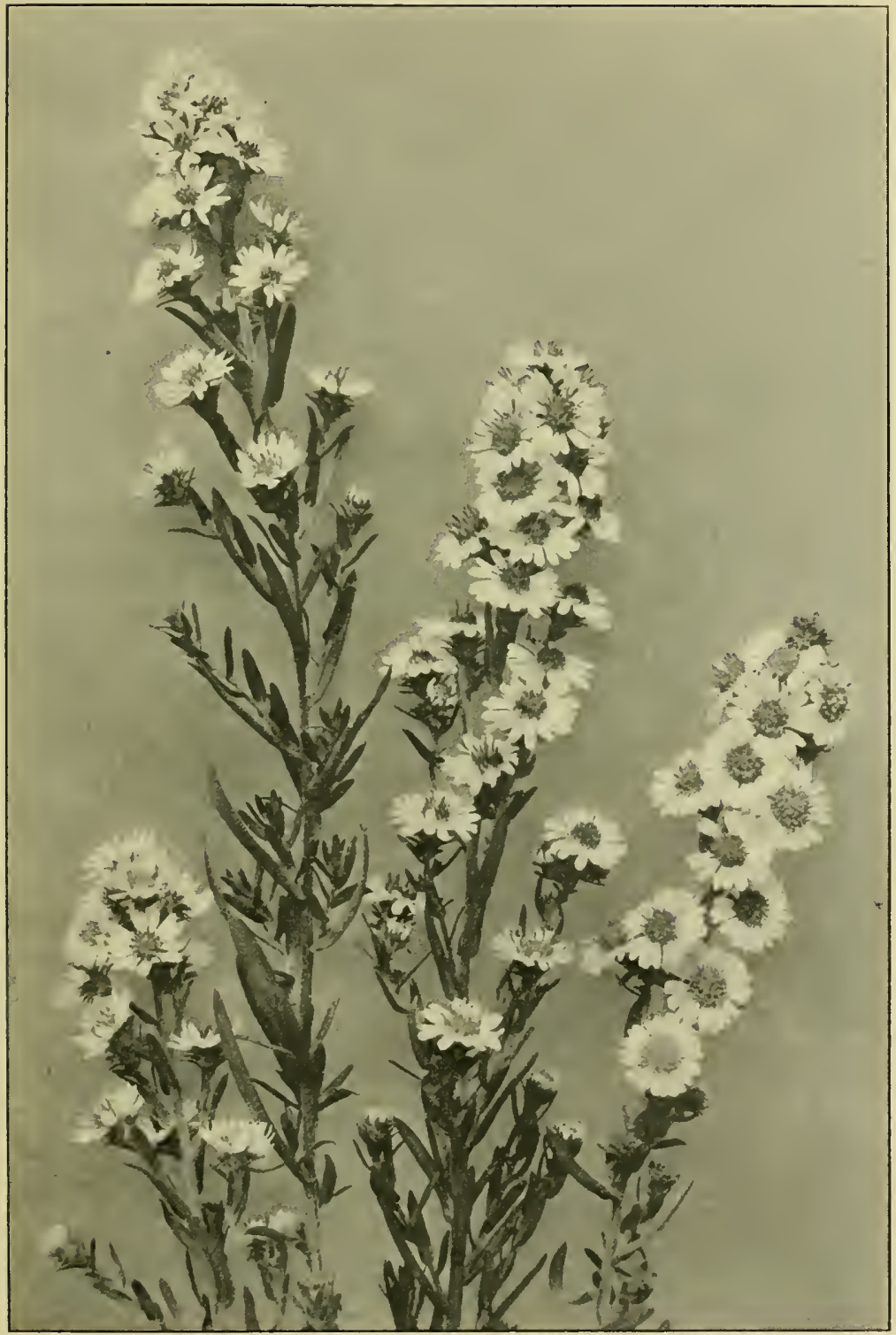

IVhite Aster

(Aster commutatus) 



\section{SWEET-SCENTED BEDSTRAW}

\section{Galium triftorum. Madder Family}

Stems: ascending, a little roughened, shining. Leaves: in sixes, narrowly oval; peduncles slender, terminal, and axillary. Flowers: in threes, or on three-branched pedicels. Fruit: hispid, with hooked hairs.

The flowers of this species of Bedstraw always grow in threes, or on three-branched stems, as might be inferred from the name triflomm. The leaves are a trifle broader than those of $G$. borcale, but the flowers of both have a four-lobed white corolla. At all times, but especially when dried, this plant has a sweet odour resembling that of vanilla. Its seeds are twolobed and are covered with tiny hooked hairs, which have earned for it the descriptive name of "Cleaver," for verily its burs cleave fast to anything with which they come in contact.

\section{WILD HELIOTROPE}

\section{Valeriana syláatia. Valerian Family}

Stems: erect from creeping rootstocks. Leaves: basal, oblong, entire ; stem-leaves petioled, three-to-seven foliolate, the divisions entire. Flowers: cymose, paniculate, more or less dimorphous; corolla funnel-form, five-lobed.

So sweet is the smell of the IVild Heliotrope that few can mistake it. The flowers are very handsome, white tinged with mauve or pink, and grow in big clusters on the top of juicy stalks from eight to eighteen inches high, and in two small axillary clusters a few inches below the terminal cyme. The foliage of this plant is handsome, the leaves being strongly veined, glossy, and of a beautiful bright green colour.

The margins of these leaves are entire, - that is, not cut or toothed, - and herein lies the difference between this plant and $V$. sitchensis, or White Heliotrope, which can only be readily distinguished from it by the fact that the latter's leaves are coarsely dentate, the flowers of both species being almost identical. A very noticeable feature of the Heliotropes is their extremely long stamens. 


\section{WHITE ASTER}

Aster commutatus. Composite Family

Stems: bushy, branched. Leaves: rigid, linear, entire, obtuse, sessile, uppermost passing into involucral bracts. Flowers: in densely crowded heads.

These charming little Asters, with their white rays and yellow centres, are quite unmistakable, and though each individual flower is small, yet they grow in such large denselyflowered wands that they present a very handsome appearance. The stiff narrow leaves grow all the way up the stalks among the blossoms. The flower is usually found in very dry sandy places.

A. alpinus, or Alpine Aster, is another species very abundant in the mountains. It grows at great altitudes and has fluffy whitish leaves and white or pale pink flowers.

\section{DAISY FLEABANE}

\section{Erigeron compositus. Composite Family}

Stems: short, densely leafy. Leaves: fan-shaped in outline, parted into linear spatulate lobes on long petioles; herbagre hirsute and rather viscidulous. Flowers: rays forty to sixty; white; disk-flowers yellow.

This Fleabane is very like a large common daisy, for it has many white rays and a big yellow centre. Most of its leaves grow out from the base, and are much cut and quite fernlike. It is found at an altitude of 7000 feet, and especially along the edge of glacial streams, though it grows also on the lower alpine meadows.

The most conspicuous difference between Asters and Fleabanes is that the latter have very numerous narrow rays, while the rays of the former are slightly broader and much fewer in number. 


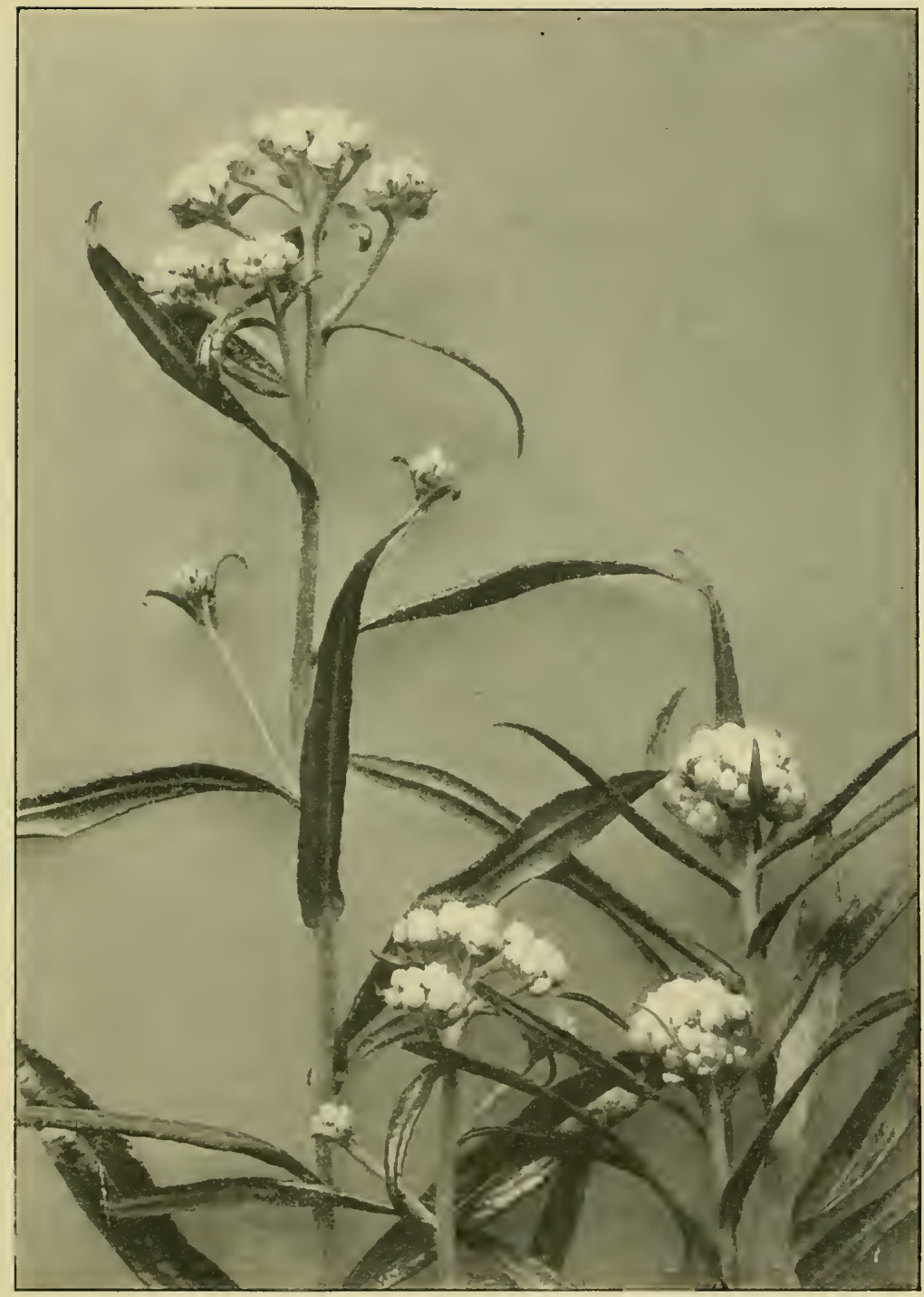

PEARLy Everlasting

(Anaphalis margaritacea) 

PLATE XXII

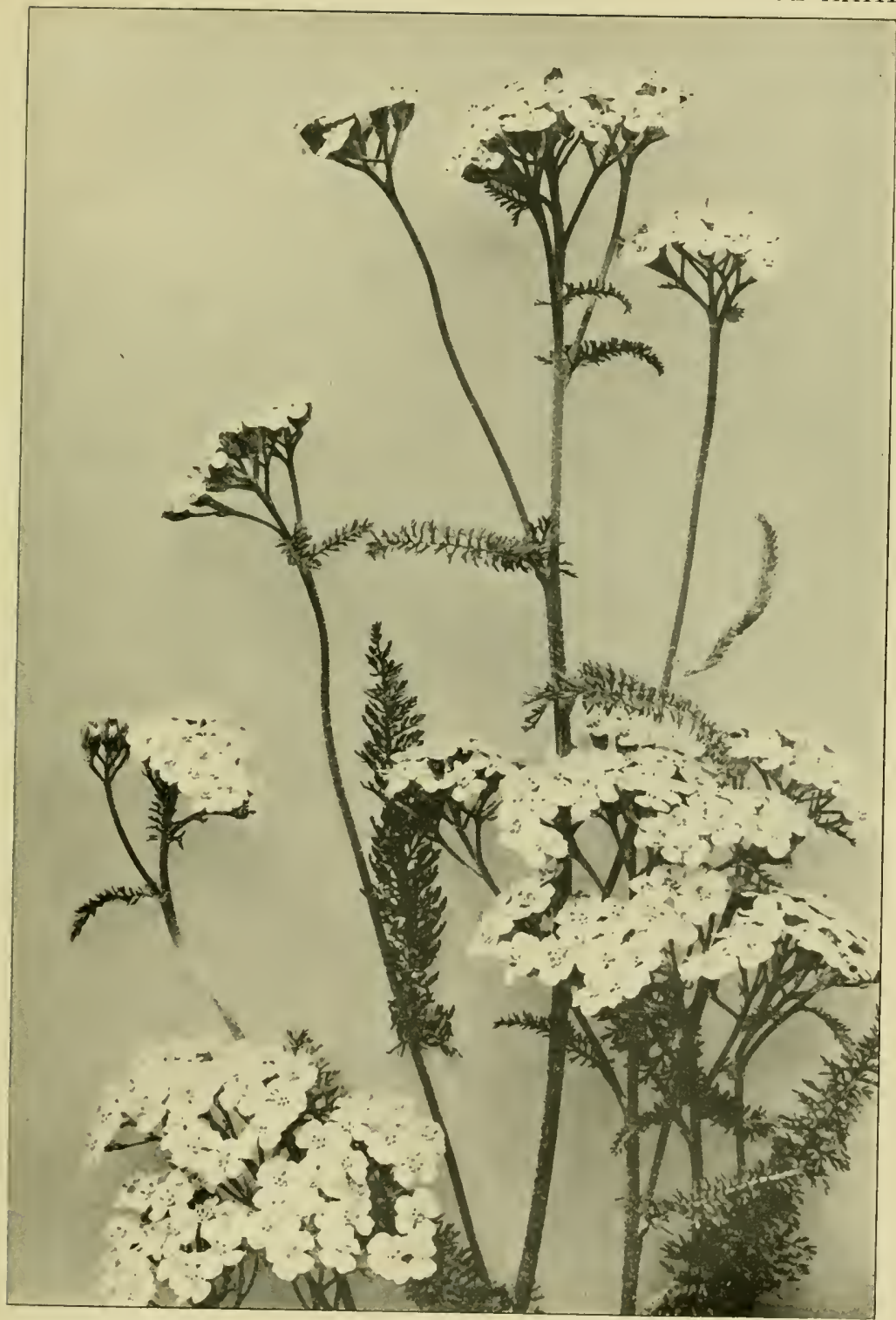

YARROW

(Achillea lamulosa) 



\section{WHITE EVERLASTING}

\section{Antennaria racemosa. Composite Family}

Freely surculose by long, slender, sparsely-leafy stolons, lightly woolly. Stems: bearing numerous racemosely-disposed heads. Leaves: broadly oval, acute at each end, densely tomentose beneath, green and glabrous above; involucre campanulate; bracts green. Flowers: staminate and pistillate heads white-tipped.

Every traveller will recognize the Everlastings at a glance, with their dry, crackling little flowers and partially, if not entirely, silky whitish leaves; the only difficulty lies in deciding to what species any particular plant belongs.

The easiest way to distinguish the White Everlasting is by the loose separate fashion in which its flower-heads grow, just a few on each little stalk and none of them bunched together; whereas the A. Hozucllii, or Mouse-ear Everlasting, has very closely clustered flower-heads and much more silky leaves. The leaves of both these plants are woolly and white underneath and smooth and green on the top. The fertile plants are taller than the sterile plants, and the little heads of fertile florets are set in green cups, their snow-white silky tufts gleaming in the sunshine, while the staminate florets have rounder, whiter scales.

A. parifolia, or Mountain Everlasting, has leaves that are white and woolly on both sides, and its florets are perfectly round in shape.

For $A$. parifolia iar. rosea see the Pink to Red Section.

A. lanata, or Alpine Everlasting, is a dwarf species growing close to perpetual snow, and is found at the great altitude of Sooo feet. It has very white and woolly stalks and many tiny leaves that are white and woolly also.

This plant somewhat resembles the Edcliciss of the Alps, and is the nearest approach to that famous flower to be found on this continent. The name Antcmaria refers to the long brown anthers, which resemble the antennx of some insect. 


\section{PEARLY EVERLASTING}

\section{Anaphalis margaritacea. Composite Family}

Stems: floccose, woolly, corymbosely branched at the summit, leafy. Leaves: linear, lanceolate, green pubescent above, woolly below. Flowers: in numerous heads; imvolucre campanulate, its bracts ovate, obtuse, finely stricate.

This is the finest of all the Everlastings, and if picked and carefully kept in a vase, will remain fresh looking for months. Its flowers are large, slightly sweet scented, and pearly white, and are often used for funeral wreaths; as if to say:

"They are love's best gift, Bring flowers - pale flowers."

\section{YARROW}

Achillea lanulosa. Composite Family

Stems: simple, or corymbosely branched above. Leaves: narrowly oblong, bipinnately dissected into numerous small linear divisions. Flowers: in numerous heads crowded in a fastigiate cyme.

A plant, or rather weed, so common that every child knows its large white and pinkish flower-heads and recognizes the disagreeable pungent odour of its lace-like leares. It is often called "Milfoil" from the abundance of its fringed foliage.

The Yarrow must unquestionably be of ancient origin, for it clerives its name Achilled from Achilles, who is supposed to have made an ointment from it wherewith to heal his wounded warriors after the siege of Troy.

\section{OX-EYE DAISY}

\section{('hrysanthemum Le'ucanthimum. Composite Family:}

Stems: glalrous, simple, the branches nearly erect. Leaves: obovate, ol)long, coarsely dentate; stem-leaves sessile, partly clasping, linear, pinnately incised, the uppermost very small, nearly entire. Flowers: solitary, or few, on long perluncles; rays twenty to thirty. Not indigenous. 


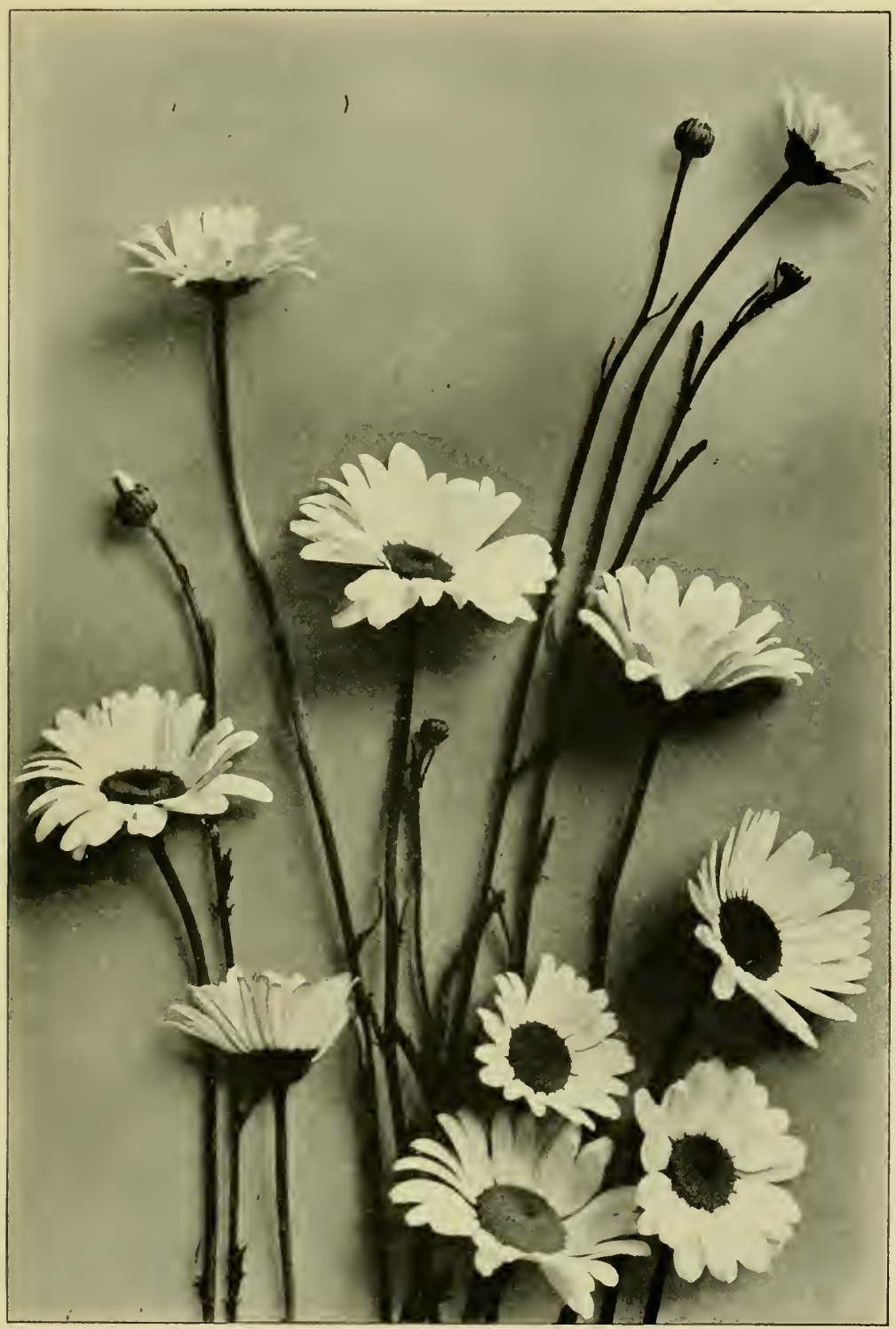

OX-EYE DAISY

(Chrysanthemum Leucanthemum) 



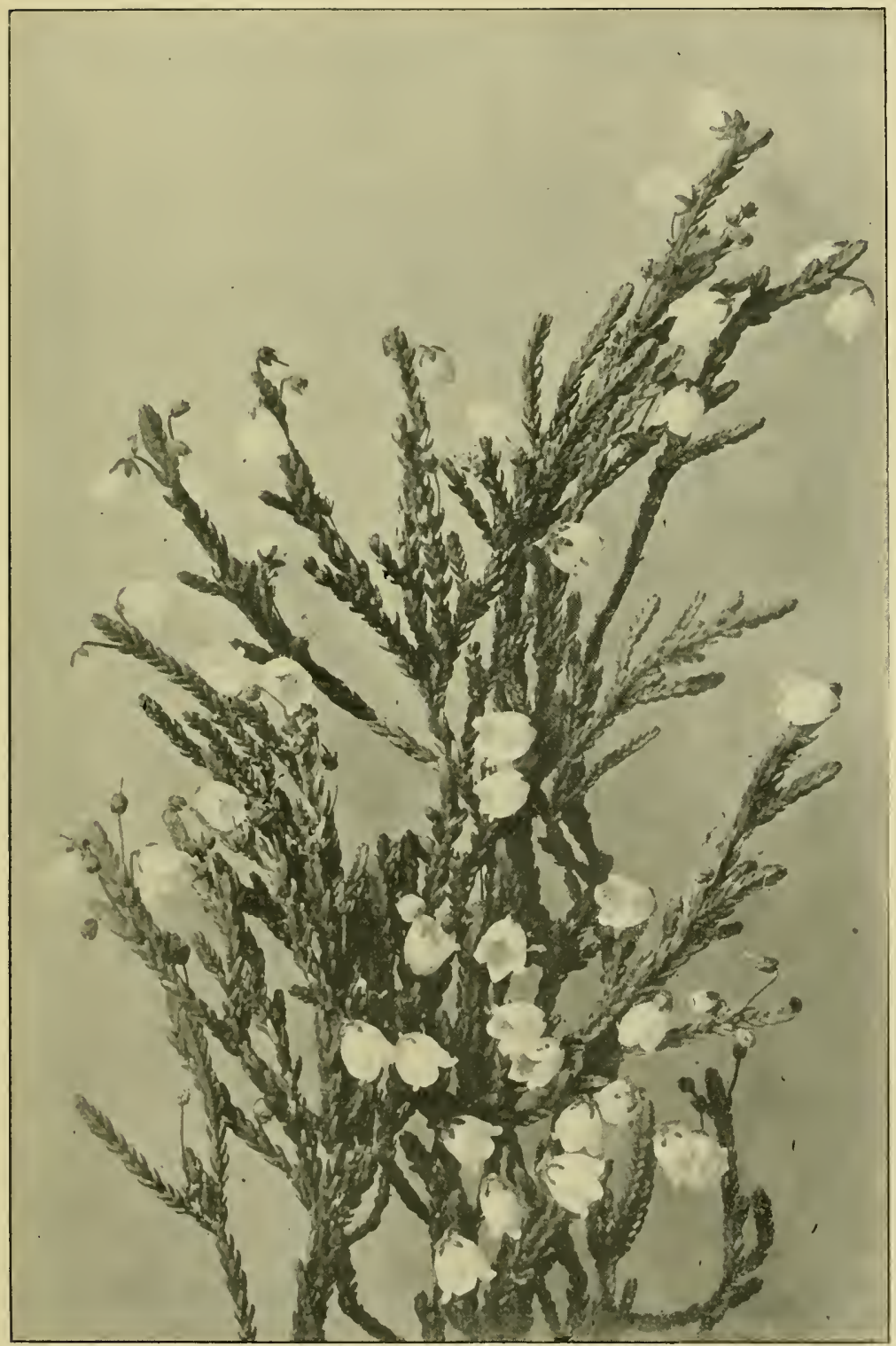

White HeAth

(Cassiope Lertensiana) 

How many poets have sung the praise of the Daisy, from Robert Burns, who clescribed the little English blossom that grows close to the turf as a

"Wee, modest, crimson-tipped flower,"

to Bliss Carman, the clever Canadian writer, who tells how

"Over the shoulders and slopes of the dune I saw the white daisies go down to the sea -

A host in the sunshine, a snow-drift in June,

The people God sends us to set our hearts free,"

and in doing so describes the big wild Ox-eye Daisies that mantle the alpine meadows with their showy white petals and golden hearts

\section{PASTURE WORMWOOD}

\section{Artemisia frigida. Composite Family}

Stems: simple or branching, silky-canescent and silvery all over, herbaceous from a suffrutescent base. Leaves: twice ternately or quinately divided into linear crowded lobes. Flowers: numerous racemosely disposed heads in an open panicle, globular.

All the Wormwoods possess a very strong odour, by means of which they may be easily recognized. This species has tiny greenish-yellow flowers growing profusely on its leafy, silky stems, while the whole plant is silvery white and covered with softest down.

A. discolor, or Green IVormwood, has green foliage and brownish-green florets, having the same pungent aromatic smell as the silvery species.

A. bicnnis, or Biennial Wormwood, has also green foliage, and its numerous greenish florets grow in clusters in the axils, where the leaves join the main flower-stalk. 


\section{PALM-LEAF COLTSFOOT}

Pctasites palmata. Composite Family

Stems: scaly, stout. Leaves: orbicular in outline, deeply seven-to-eleven cleft, green and glabrous above, densely white tomentose beneath. Flowers: in a fastigiate panicle.

The chief distinction between the different species of Coitsfoot lies in the shape of their respective leaves. Those of the Palm-leaf Coltsfoot are exactly like a large palm leaf, while its blossoms are white and very fragrant. The flower-stalks are thick and juicy and covered with small narrow leaves. It has silky-haired seeds like a dandelion.

P. sagittata, or Arrow-leaf Coltsfoot, has huge leaves with two very marked pointed lobes at the base. Its flower-heads grow compactly at the top of very stout stalks, and are white and fragrant.

P. frigida, or Arctic Coltsfoot, has few blossoms, a scaly stem, and very irregularly lobed leaves. The foliage of all the Coltsfoots is green and smooth on the top, and white and woolly underneath. They are coarse uninteresting plants.

\section{WHITE THISTLE}

Cnicus eriocefhalus. Composite Family

Stems: loosely arachnoid-woolly, very leafy. Leaves: pinnatifid into numerous crowded, prickly, short lobes. Flowers: sessile and crowded into a leaf-subtended nodding glomerule.

The flowers of these white or cream-coloured Thistles are surrounded by a mass of narrow prickly leares and are large and handsome.

\section{WHITE HEATH}

Cassiope Mertensiana. Heath Family

Stems: rather stout, rigid, ascending with fastigiate branches, lowgrowing. Leaves: glabrous, carinate, and not furrowed on the back, imbricated in four ranks; corolla five-lobed. 
PLATE XXVI

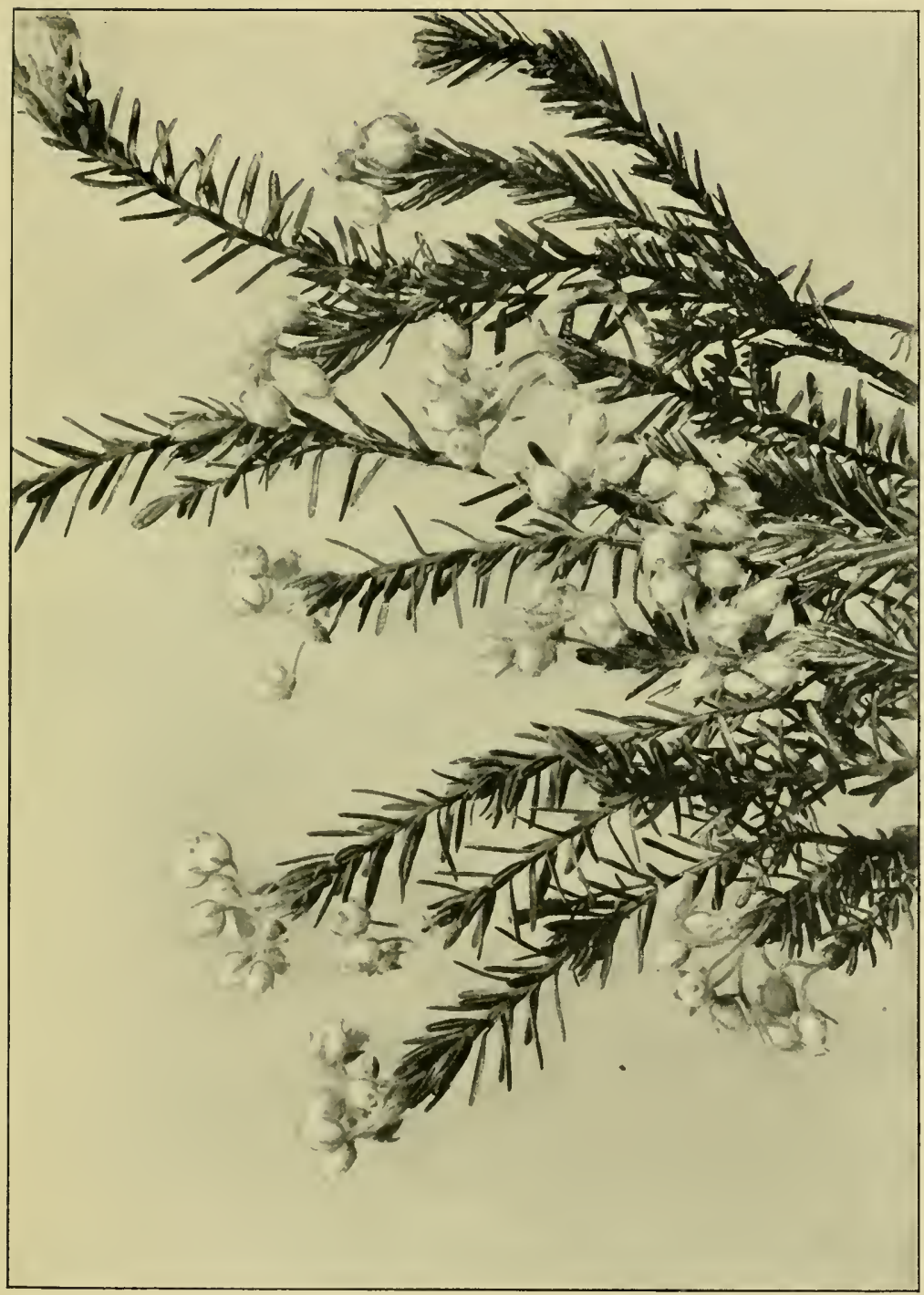

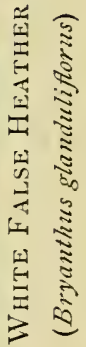



PLATE XXVII

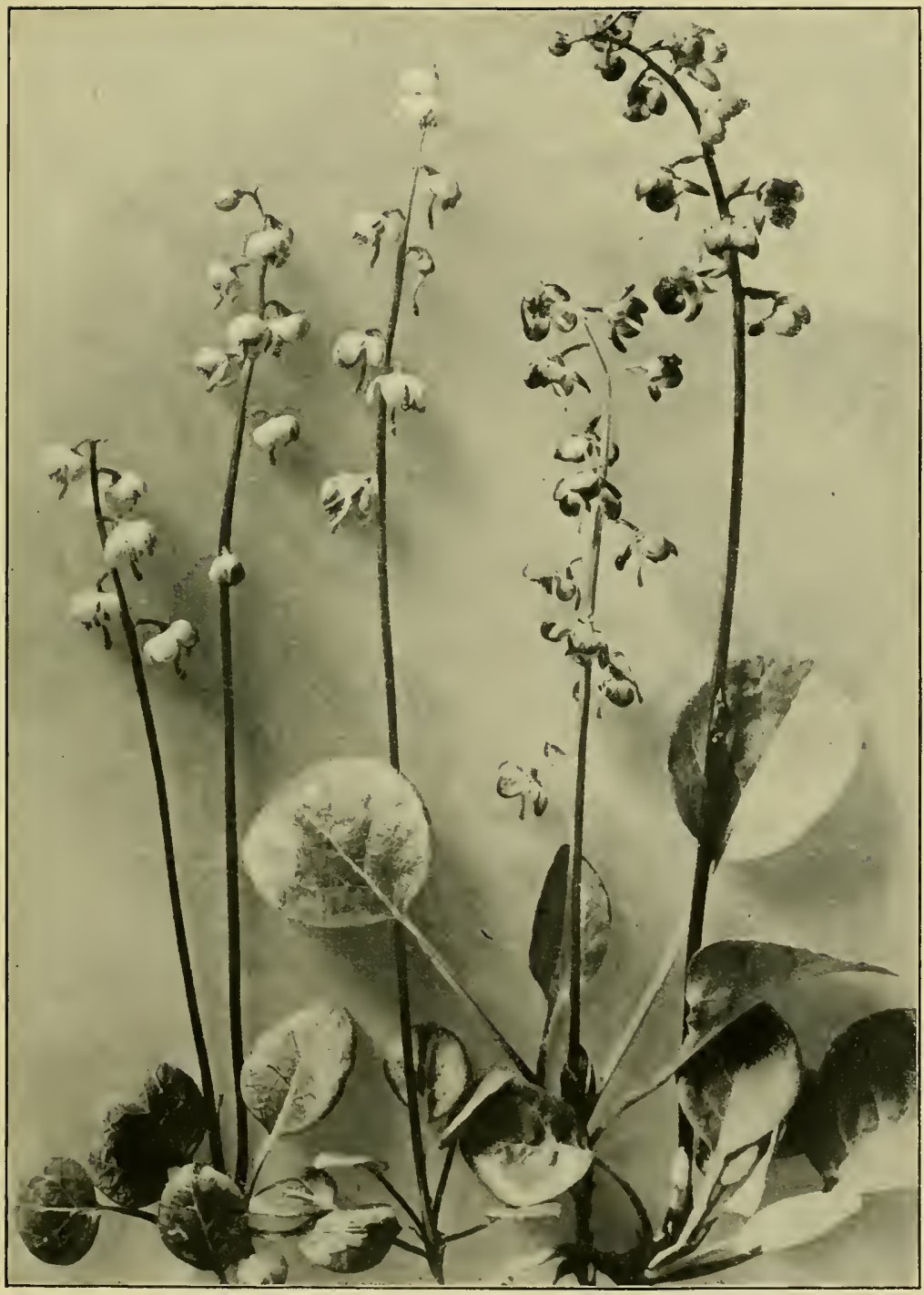

GREEN-FLOWERED WINTERGREEN (Py'rola chloranthat) RED WINTERGREEN (Pyrola asarifolia) 

The beautiful white mountain Heath grows abundantly at high altitudes and is much prized by travellers. Its branches appear four-sided by reason of the manner in which the tiny leaves grow on them, and from these branches slender stalks are sent forth bearing at their tips waxen nodding bells, each composed of a five-lobed corolla with a small green calyx.

"Meek dwellers mid yon terror-stricken cliffs,

With brows so pure, and incense-breathing lips,

Whence are ye? Did some white-winged messenger,

On Mercy's missions, trust your timid germ.

To the cold cradle of eternal snows;

Or, breathing on the callous icicles,

Bid them with tear-drops nurse ye?"

\section{WHITE FALSE HEATHER}

\section{Bryanthus glanduliflorus. Heath Family}

Stems: rigid, fastigiately branched. Leaves: numerous, crowded, but somewhat spreading, linear-oblong, obtuse, narrowed at the base to a short petiole. Flowers : corolla short-lobed, glabrous.

The flowers of the White Heather are like little fat creamcolourect bulbs, with a tiny opening that is lobed. Its leaves are longer and more spreading than those of the Heath, near which it usually grows.

\section{GREEN-FLOWERED WINTERGREEN}

\section{Pyrola chlorantha. Heath Family}

Stems: three-to-ten flowered. Leaves: small, orbicular, coriaceous, not shining. Flowers: noddling; calyx-lobes short, orate, acute; petals very obtuse; stamens declined; anthers distinctly contracted below the openings, with beaked tips; style declined, and curved upwards towards the apex, longer than the petals.

This Lily-of-the-Valley-like plant is found in the dry woods among the moss, and always in the shade. On a tall, slender, single-bracted stalk grow numerous little nodding greenishwhite bells, five-lobed, with yellow-brown stamens and a long, 
protruding, green style that is curved upwards at the apex and tipped by a large five-parted stigma. The leaves, round and small, grow in a cluster at the base of the plant, which springs from running roots. It has a slight sweet odour, and, in common with all the Pyrolas, is an evergreen.

In the accompanying illustration, Plate XXVII, this Greenflowered Wintergreen is shown, together with $P$. asarifolia, or Red Wintergreen, a description of which is given in the Pink to Red Section.

\section{ONE-SIDED WINTERGREEN}

\section{Pyrola secunda. Heath Family}

Stems: caulescent from a branching base. Leaves: ovate, mostly thin, acute, narrowed at the base, crenulate, serrate. Flowers: numerous, in a dense, secund, drooping raceme; petals greenish; stamens unequally connivent around the pistil; style straight and longer than the petals.

In the young plant the stem of the One-sided Wintergreen will be found erect, but as the days pass and the little buds open, the weight of the secund raceme bends it over until it droops gracefully downwards. The flowers, which all grow on one side of the stem, are greenish-white in hue, and the long style protrudes far beyond the petals. The leares grow at the base of the plant and are oval, their margins being serrated; they extend a short way up the stem, which is frequently bracted above.

\section{SMALL WINTERGREEN}

I'yrola minor. Ileath Family

Stems: seven-to-sixteen flowered. Leaves: orbicular to oval, crenulate, mucronate at the apex, rounded subcordate at the base. Flowers: racemose, noddling; calyx-lobes triangular, orate; style straight, short.

A smaller, more delicate species of Wintergreen, found principally near running water, and which has whiter bells than 
PLATE XXVIII

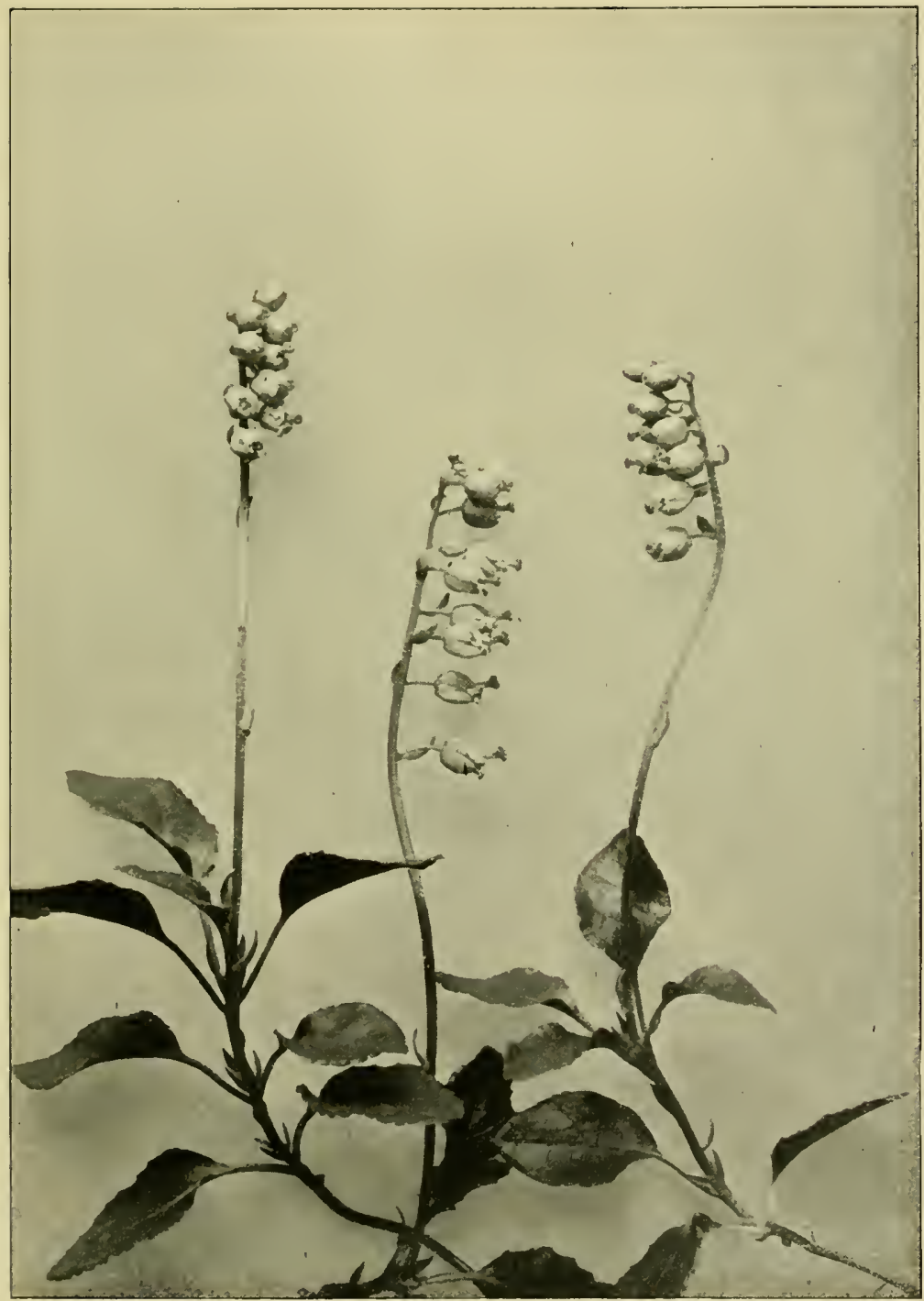

ONE-SIDEI) WINTERGREEN

(I'yrola secundi) 

either of the two preceding forms. It may always be distinguished from other Pyrolas, even in bud, by the fact that it has a short style, which does not protrude beyond the petals of the gobular blossoms. A slight fragrant scent emanates from its waxen bells.

\section{ONE-FLOWERED WINTERGREEN}

\section{Moneses uniflora. Heath Family}

Stems: bearing three whorls of leaves at the base, continued above into a bracted scape. Leaves: orbicular, petioled, serrulate. Flowers: solitary, drooping; petals five, widely spreading, sessile; style straight; stigma peltate, large, conspicuous, with five narrow lobes.

Dr. Gray has called this fragrant flower a "single delight," and certainly it is a joy to the traveller to find its solitary drooping blossoms bent close down upon the soft green carpet of the July woods. In the deep shade of the conifers beds of these exquisite waxen Wintergreens grow in profusion, each flower hanging its head and resembling a shining star. Turn its face upwards, however, and you will find its white petals have ten yellow-tipped stamens placed at their base, and that the style, which is very large and long, projecting from a conspicuous round green ovary, is crowned by a five-lobed stigma. The leaves are set in three circles on the stem, close to the ground, and are dark green, smooth-surfaced, and have serrated margins.

The One-flowered Wintergreen is a dweller in the darkest corners of the woods, where

"That delicate forest flower, With scented breath, and look so like a smile, Seems, as it issues from the shapeless mould, An emanation from the indwelling life." 


\section{SWEET ANDROSACE}

Androsace Chamajasme. Primrose Family

Stems : slender. Leaves: in more or less open rosulate tufts, one-nerved, ovate. Flowers: in capitate umbels.

The sweet smell of these clelicate little clustered blossoms, that grow from one to three inches above the soil and fill the air with fragrance, is most attractive. Their primrose-like petals, of creamy or pinkish hue, look up with yellow eyes to greet each passer-by, while rosulate tufts of tiny narrow leaves are set about the slender stems.

\section{ALPINE ANDROSACE}

Androsace septentrionalis. Primrose Family

Stems: slender, many-flowered. Leaves: rosulate, lanceolate. Flowers: calyx-tube obpyramidal, with subulate, acute, green lobes; corolla-lobe obovate, longer than the calyx.

A very different species from the foregoing one, having much branched, thread-like stems, bearing numerous tiny white flowers.

\section{STAR-FLOWER}

\section{Trientalis Americana. Primrose Family}

Rootstock creeping, sencling up many stem-like branches, which are naked below, the leaves all in a verticil of five to ten at the summit. Leaves: membranous, lanceolate, acuminate at both ends, sessile. Flowers: solitary or few; calyx usually of seven sepals: corolla wheel-shaped, of seven petal-like segments.

The pretty blossoms of this Star-flower are generally white, though sometimes tinged with mauvish-pink, and so gracefully are they poised on slender stalks above a whorl of pointed leaves that every puff of wind blows them gently to and fro. The number seven recurs with marked frequency in this particular plant, - the calyx is seren-parted, the corolla 
PLATE XXIX

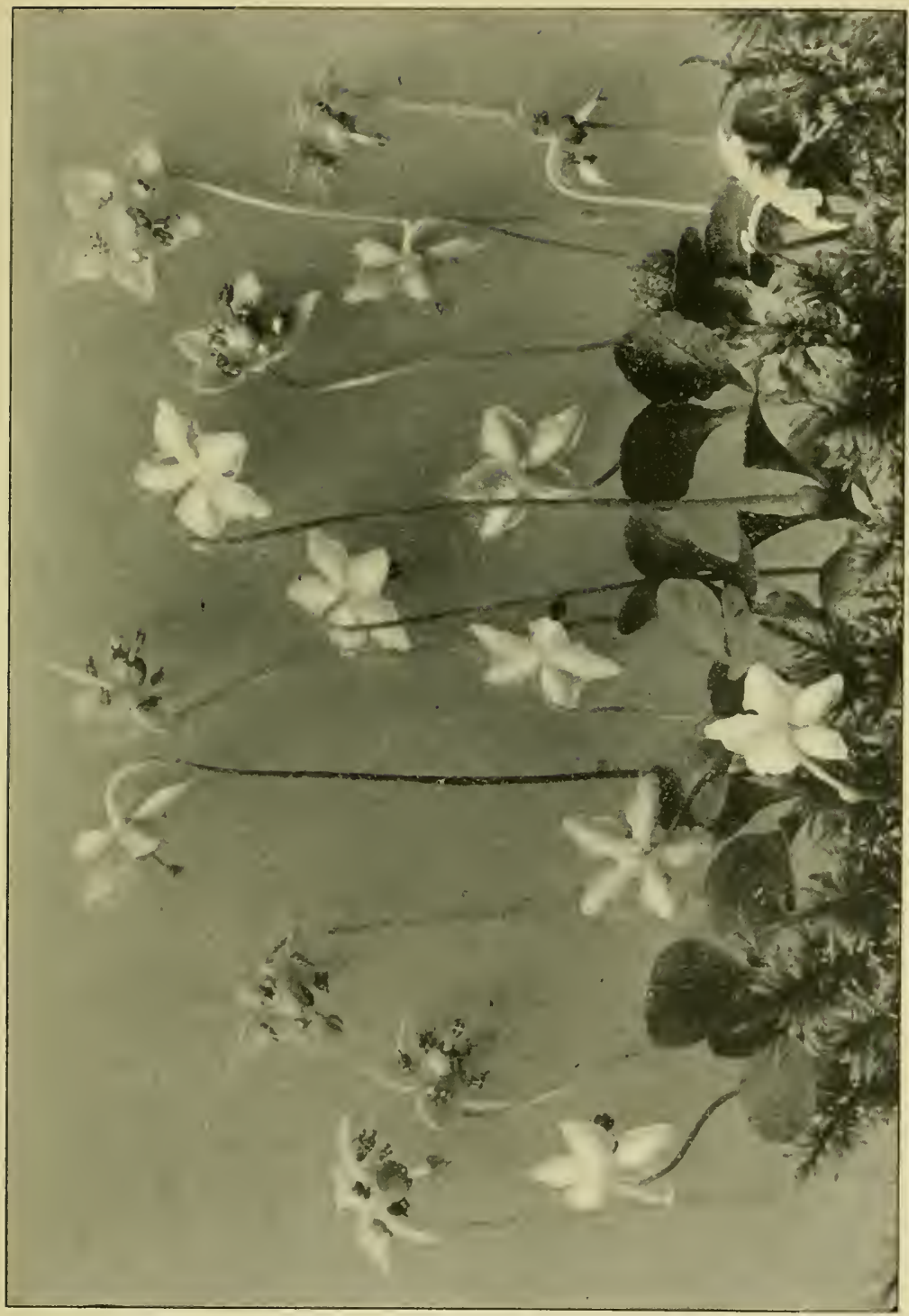

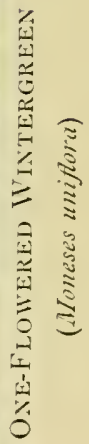





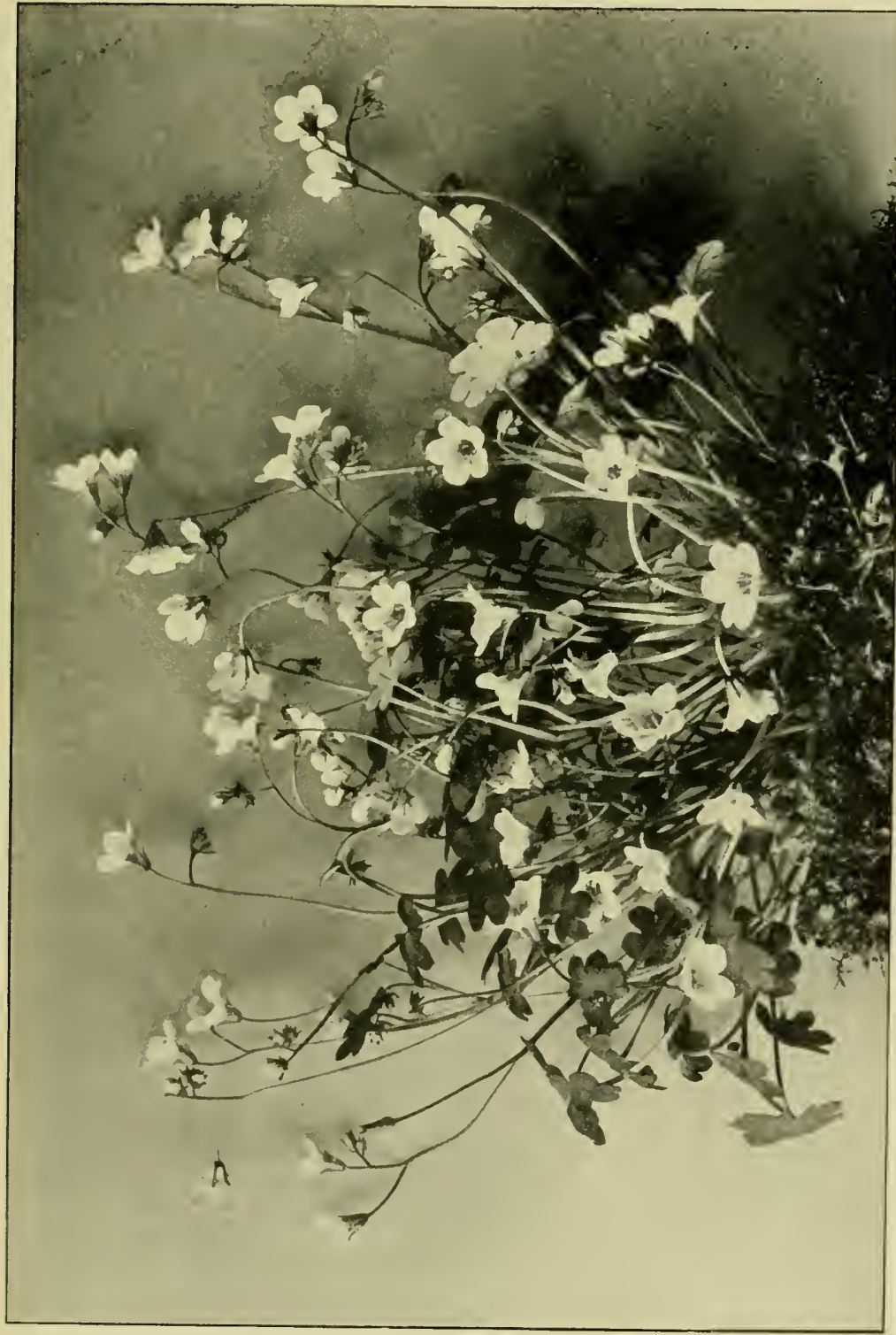

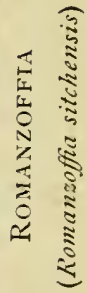



segments are seven, and the stamens seven, while the leaves of the whorl also are usually seven in number, some being large and some small.

Bryant writes of the alpine meadows,

"Where star-flowers strew the rivulet's side,"

but as a matter of fact it is generally in the shady woods, near the foot of some large forest tree, that these dainty little flowers are found

\section{BUCKBEAN}

\section{Menyanthes trifoliata. Gentian Family}

Rootstock thick, scaly, marked by the scars of bases of former petioles. Leaves: trifoliate, leaflets oblong, entire, obtuse at the apex, narrowed to the sessile base. Flowers: in a raceme borne on a long, scape-like, naked peduncle; calyx short; corolla funnel-form, five-cleft, its lobes bearded within.

This is a perennial swamp herb whose lovely white flowers and triple leaves are the glory of many a secluded mountain marsh. The face of the five white or purplish-pink divisions of the corolla are covered with soft hairs, which give the flowers a dainty feathery appearance, and inside the tube are placed the five stamens, while the style is long and projects beyond them.

\section{ROMANZOFFIA}

Romanzoffia sitchensis. Water-leaf Family

Stems: slender, scape-like, ascending or spreading. Leaves: round-reniform, three-to-seven lobed on slender petioles. Flowers: in a loose terminal raceme; corolla funnel-form, the broad lobes rounded.

One of the most exquisite fragrant alpine plants, that grows

"Where the sunlight fills the hours,

Dissolves the crust, displays the flowers."

At high altitudes, when the warmth of July has melted the snow and set the flowers free, you will find the creamy 
blossoms of this Romanzoffia in many a nook amongst the forbidding rocks, its corollas gleaming like shimmering pearls in the green setting of their round scalloped leaves. The texture of these flowers is simply marvellous, for they have a bloom upon them so beautiful that it resembles nothing less than richest white velvet, while in their centres a few pale yellow stamens give to each blossom a heart of gold.

Romanzoffia is seldom found below an altitude of 6000 feet, and where the cliffs rise bleak and barren, where the ways are ice bound and the rocks are bare, there it is a joy to find this lovely plant snugly ensconced in some tiny cleft that is watered by the melting snows. Only those who have toiled and climbed in search of it can know the full delight of its discovery.

\section{WHITE LOUSEWORT}

\section{Pedicularis racemosa. Figwort Family}

Stems: glabrous, leafy to the top. Leaves: all cauline, lanceolate, undivided, finely serrulate. Flowers: few, in short leafy racemes: calyx oblique, deeper cleft before than behind, the lobes abruptly acuminate; galea produced into an incurved beak, nearly as long as the broad lower lip, hamate-deflexed.

The dull white or very pale yellow beaked flowers of the White Lousewort are set in a close cluster at the top of the stalks, and are embedded amongst small deeply-fringed leaves.

The repellent common name of this plant is derired directly from the Iatin one, which was bestowed upon it because once upon a time farmers believed that when their flocks fed upon these flowers the sheep were liable to be attacked by certain tiny lice, called pediculus.

Four species of Lousewrort grow in the mountain regions, two of which will be found in the Pink to Red Section of this book, while a fourth one is Pedicularis contorta, or Contorted Louscwort, a plant very like l'. racimosa, but having its cream-coloured flowers set singly all the way up on the 
PLATE XXXI

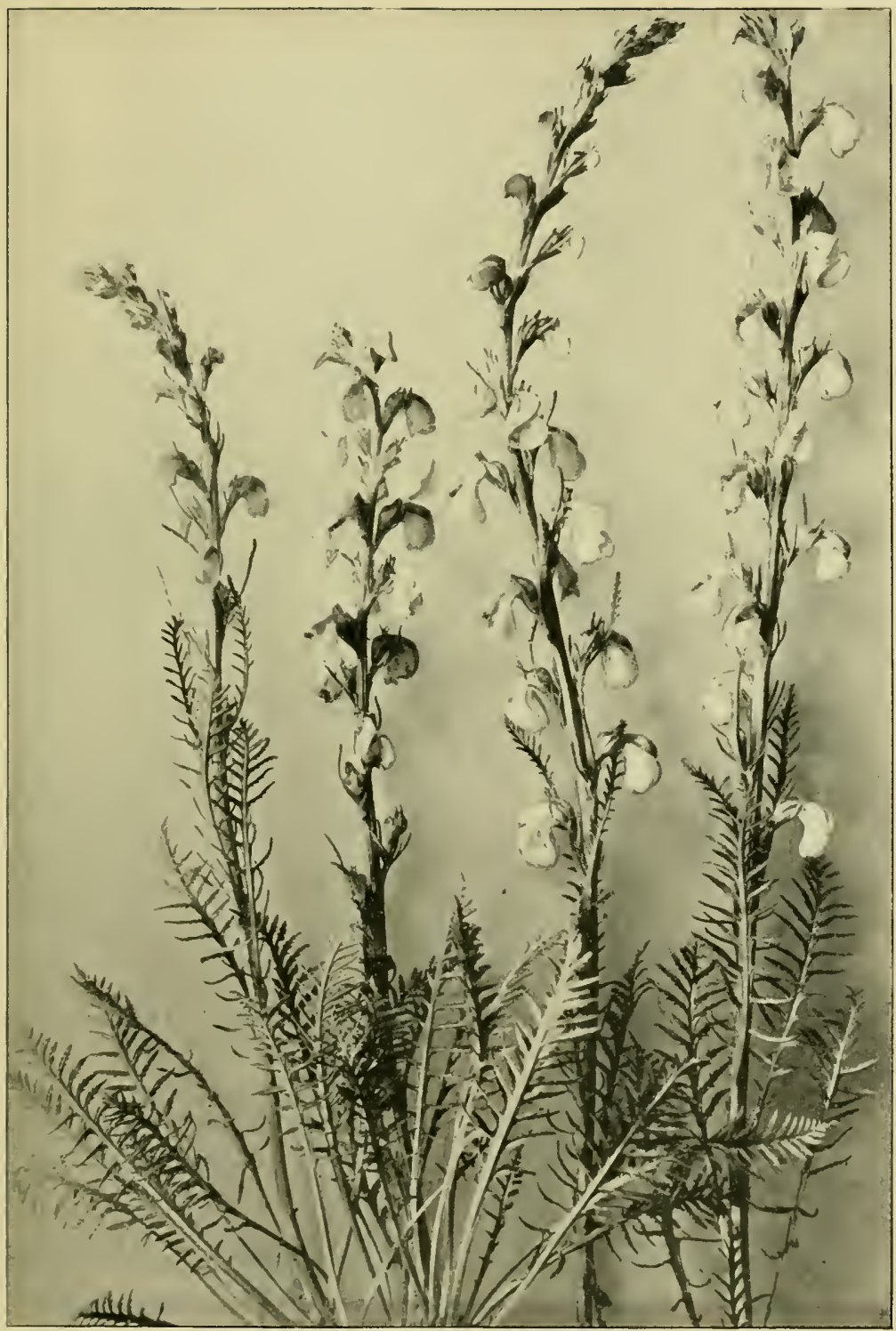

CONTORTED LOUSEWORT

(Pédicularis contorta) 

slender stalks. Its foliage is fern-like and often tinged with reddish-brown; long leaves grow out from the base, and small ones are interspersed with the numerous blossoms on the stems.

The Contorted Lousewort grows at very high altitudes, being usually found at 7000 feet.

\section{COMMON PLANTAIN}

\section{Plantago major. Plantain Family}

Rootstock short, thick, erect. Leaves: spreading, ovate, entire; spike dense, obtuse at apex. Flowers: perfect, proterogynous; sepals broadly ovate, scarious on the margins. Fruit: pyxis seeded, circumsessile near the middle.

The Common Plantain is so familiar to travellers that it calls for no special description. It has greenish flower-spikes and reddish seeds.

P. Rugclii, or Pale Plantain, is somewhat similar to the preceding species, but has a slightly broader leaf and a less dense flower-spike.

\section{LAMB'S QUARTERS}

\section{Chenopodium album. Goosefoot Family}

Stems: slender, erect, commonly much branched. Leaves: rhombicovate, the upper ones lanceolate, obtuse or acute. Flowers: bractless, densely clustered in a compound panicled spike; calyx segments strongly keeled. Fruit: seed firmly attached to the pericarp.

A weed that abounds near habitation, even in the mountain regions. A commonplace plant, and yet one that is not altogether without beauty, since its foliage is of an unusually delicate tender green. The white flowers, which grow in dense spikes, are inconspicuous. 


\section{TALL ERIOGONUM}

\section{Eriogonum umbellatum. Buckwheat Family}

Stems: depressed and shrubby below, much branched. Leaves: oblong, white tomentose below, green and glabrous above; peduncles six to fifteen inches high, naked, bearing a simple umbel of three to ten rays, subtended by a whorl of leaves.

A somewhat rare and most curious plant. In dry stony places and on rocky slopes you will find the long-stalked blossoms of the Tall Eriogonum, with its handsome flat-topped clusters of cream-coloured flowers, tipped and tinged with vivid rose pink, that have a peculiar bunch of tiny narrow leaves set just where the little stems of the individual flowerumbels spring from the top of the main stalk.

It is also a most fascinating plant, both by reason of the fact that its fine cream and rose blossoms grow in barren localities, and also because its leaves (which are green above and silvery beneath) grow near to the ground, on slender, branching, woody stems, while the flower-stalks are extremely long, often reaching a height of over twelve inches.

$E$. androsaccum, or Dwarf Eriogonum, is the alpine species, and almost an exact reproduction in miniature of its "Tall" relation. The chicf difference between the two plants is that the Dwarf Eriogonum is more hairy and woolly, and generally has cream-coloured flowers without any tingeing of pink. It only grow's about three inches high, and is found at 7500 feet.

\section{ALPINE BISTORT}

\section{l'olygommm arifipum. Buckwheat Family}

Stems: slender, simple. Leaves: ovate, subcordate, attenuate at base; cauline leaves lanceolate. Flowers: raceme narrowly cylindric, densely flowered, bearing a number of oroid-conic bulblets at base.

The name Polysonmm comes from the Grecis, its neaning being " many kneed," and refers to the enlarged joints of the 


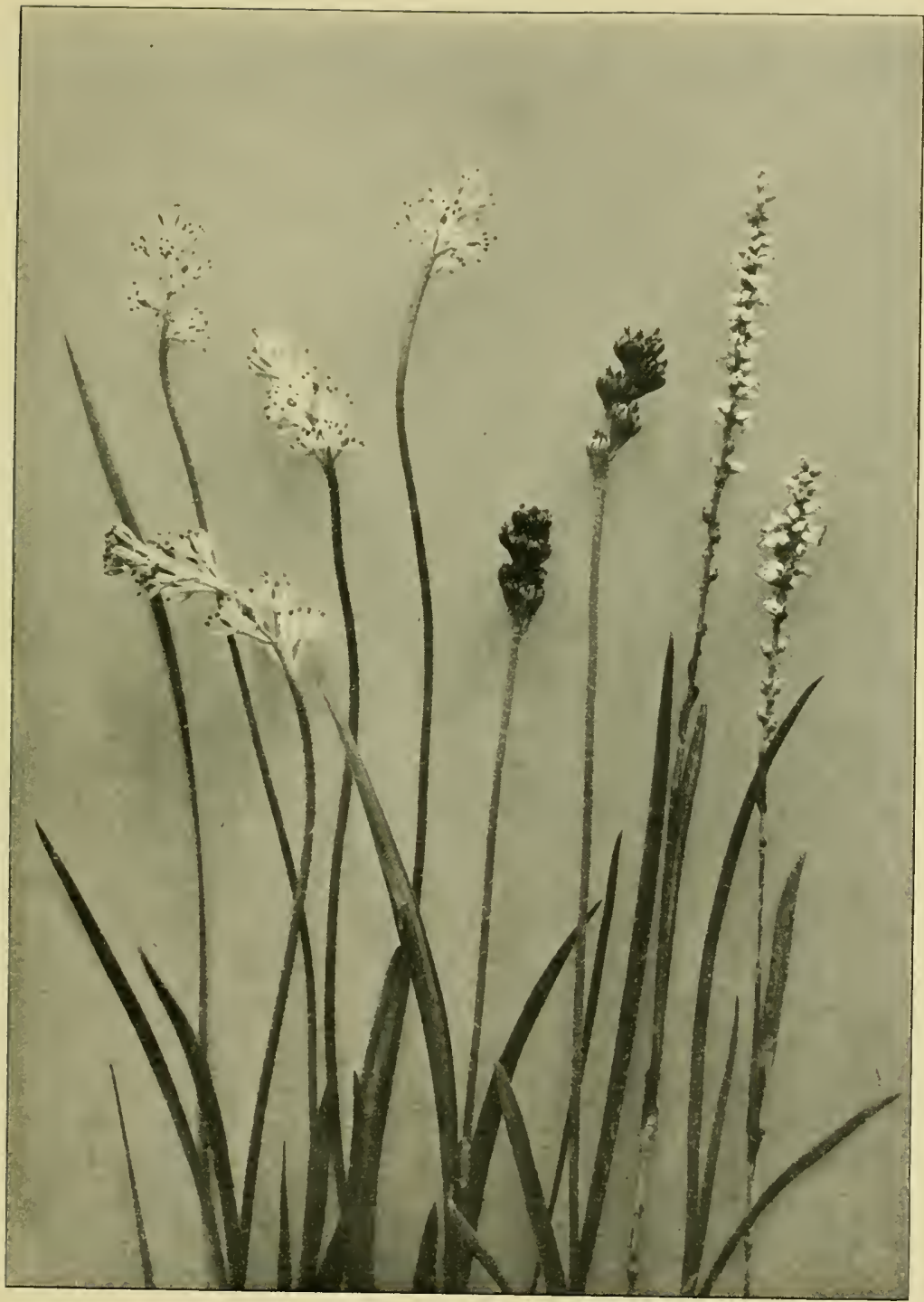

ALPINE BISTORT (Polygonum zivifarum)

ASPHODEL (Tofieldia glutinosa) 

stems, which are sheathed by the stalks of the long-shaped leaves. The flowers are very numerous in the mountains, are white to rose colour, and grow in dense narrow spikes, which have several little bulbs below the full-blown blossoms. The seeds are red. See Ilate XXXII.

A description of Polygonum amphibinm, or Water Persicaria, will be found in the Miscellaneous Section.

\section{WHITE COMANDRA}

Comandra pallida. Sandalwood Family

Stems: glaucous, slender, simple, very leafy. Leaves: linear, acute, sessile. Flowers: cymes several-flowered, corymbose, clustered at the summit, peduncles short.

The Comandra is parasitic on the roots of other plants. It has pretty little whitish-green flowers, which grow in clusters and are bulb-shaped at the base, spreading out into five lobes at the top. The leaves are very narrow and grow close to and all the way up the stalk, and the fruit is a nut-like berry, which retains at its tip the upper short part of the calyx.

C. livida, or Swamp Comandra, differs from the foregoing species in that it has wider leaves, each one growing on its own tiny stalk attached to the main stem; and whereas the flowers of the White Comandra grow in clusters at the top of the stems, those of the Swamp Comandra grow in the axils of the leaves lower down on the stems, and its fruit is a roundish red and edible berry.

\section{CORAL-ROOT}

Corallorhiza innata. Orchid Family

Root coralloid, branching. Stems: glabrous, clothed with closely sheathing scales. Flowers: in long racemes on short minutely bracted pedicels; sepals and petals narrow, lip short; spur a sac adnate to the summit of the ovary. Fruit : capsule oblong. 
A plant impossible to mistake, for its roots are exactly like branches of coral, composed of thick, white, blunt fibres, and may be found in moist shady places. The flowers grow in a raceme on single, thick, fleshy stems, that are clothed with closely sheathed bracts and are of a queer purplish-green colour, frequently marked with white. It has no leaves.

The Coral-root is a saprophyte; that is to say, it lives upon the dead and decomposing forms of other plants, and this explains why it is such a vegetable degenerate of the beautiful family of orchids. It has lost its leaves, also its chlorophyll, or honest green colouring matter, through its bad habits, and to-day belongs to that pirate tribe which feeds upon food already assimilated by another, and thereby incurs the clispleasure of Nature, whose laws demand honest conduct in her kingdom as sternly as do those of man; and so, when the Coral-root refused to manufacture its own upbuilding materials out of the carbon dioxide of the atmosphere, and proceeded to prey upon decaying matter, Nature took away its leaves and chlorophyll and only left it sufficient branching extensions at the base to secure it in the soil.

\section{HEART-LEAFED TWAYBLADE}

\section{Listera cordata. Orchid Family}

Root fleshy-fibrous. Stems: very slender. Leaves: sessile, cordate, ovate, mucronate. Flowers: in racemes, minute pedicels bracted; sepals and petals oblong-linear, lip narrow, the segments setaceous and ciliolate.

A small orchid with two large leaves growing midway up its slender stem, by which it may always be readily recognized. The flowers are purplish-erreen, very tiny, and are set in a small raceme at the top of the stalk. It grows in the cool woods.

L. conirallarioides, or Broad-lipped Twayblade, also has the same two distinguishing stem-leaves, which, however, are rounder than in the foregoing species, while its flowers are 


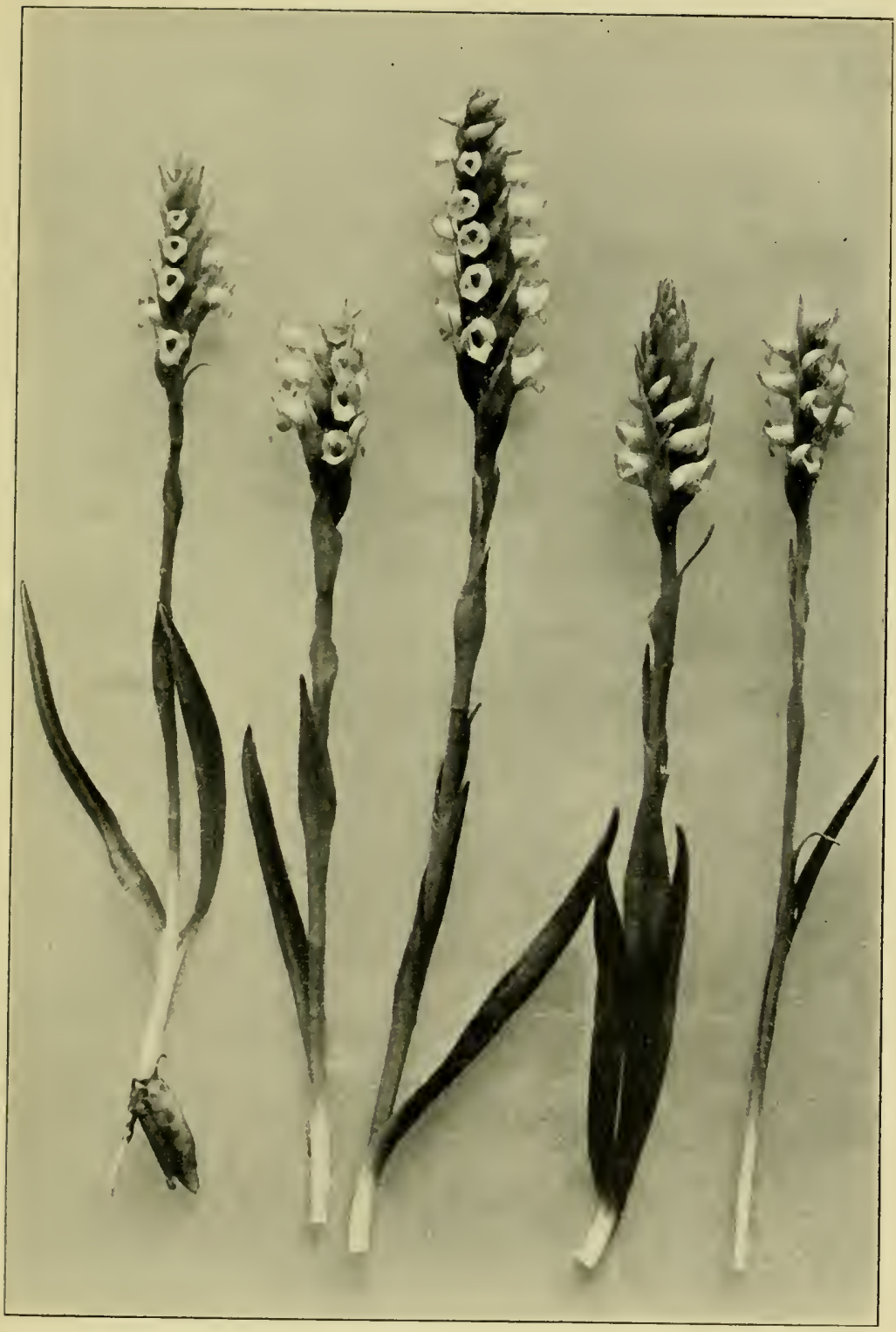

Ladies' Tresses

(Spiranthes Romanzoffuna) 105 

yellowish-green, fairly large, and possess a broad lip with two lobes at the delicate apex.

The Twayblades present a strong contrast to the Coralroot. They are conspicuously green and healthy of leaf.

\section{LADIES' TRESSES}

spiranthes Romansoffana. Orchid Family

Root tuberous. Stems: glabrous, leafy below, bracted above. Leaves: oblong-lanceolate. Flowers: spike dense, in three rows, conspicuously bracted; perianth white, the petals and sepals all connivent, lip recurved, ovate-oblong, contracted below the narrower wavy-crenulate summit.

This is the last orchid of the season, found chiefly in wet marshy places, just when the power of the summer sun begins to wane. It is a beautiful fragrant flower, growing in dense snowy spikes, and has long narrow leaves. Considering that orchids are reckoned as amongst the rarest and richest treasures of Nature, it is strange how many species of them grow wild in the mountains. Of course they are all terrestrial ones; we have none of the kinds which grow on trees and develop false bulbs.

\section{RATTLESNAKE PLANTAIN}

\section{Goodyera Menziesii. Orchid Family}

Stems: scape glandular pubescent. Leaves: blotched with white, ovate. Flowers: galea concave, ovate, with a short, spreading, recurved tip; anther ovate, pointed on the base of the stigma into a gland-bearing awlshaped beak.

This plant has a cluster of leaves at the base only; these are covered with a network of white veins and frequently also have white blotehes on them. The flowers grow in a bracted spike, are greenish-white, and have a very hairy stalk.

Goodycra repons, or Small Rattlesnake Plantain, has also peculiar white-veined leaves, but in this species they grow up the stalk as well as at its base. The whole plant is smaller than $G$. Mensicsii, and its insignificant flowers grow only on 
one sicle of the stem, which is much bracted and hairy. The name "Rattlesnake" applies to the resemblance between the curiously veined leaves and the body of a snake. This plant frequently grows in decaying wood.

\section{LONG-BRACTED ORCHIS}

\section{Habenaria bracteata. Orchid Family}

Stems: stout. Leaves: lanceolate, obtuse, the upper ones much smaller, the bracts two or three times longer than the ovaries. Flowers: green, the spike loosely flowered; petals very narrow; sepals ovate-lanceolate, dilated at the base; lip oblong-spatulate, three-toothed at the apex, and more than twice as long as the sac-like spur.

This is one of the conspicuous green orchids which grow in great profusion in the mountain regions. It has a stout juicy stem, broad leaves, and many long pointed bracts on its flowerspike. Usually found in wet places, this Orchis may always be distinguished by the long bracts, from which it derives its name.

\section{SMALL ORCHIS}

\section{Habenaria obtusata. Orchid Family}

Stems : slender, naked, four-angled. Leaves : leaf solitary, basal, obovate. Flowers: spike long, loosely flowered, green; petals short, dilated, connate with the base of the column; sepals upper one erect, green with white margins; lip entire, lanceolate, deflexed; spur as long as the lip, blunt; anther-sacs widely divergent; glands small and thick.

A delicate green and white Orchis that may always be known by its single basal leaf. It is very like a white and green Lily-of-the-Valley, and its flowers grow widely separated on the slender stalks.

\section{LEAFY ORCHIS}

\section{Habenaria hyperborea. Orchid Family}

Stems: stout. Leaves: lanceolate, acute. Flowers: small, green ; spike narrow, petals and sepals ovate, obtuse, lipper sepal crenulate at the apex: lip lanceolate, entire, olstuse; spur equalling the lip, glands small. 


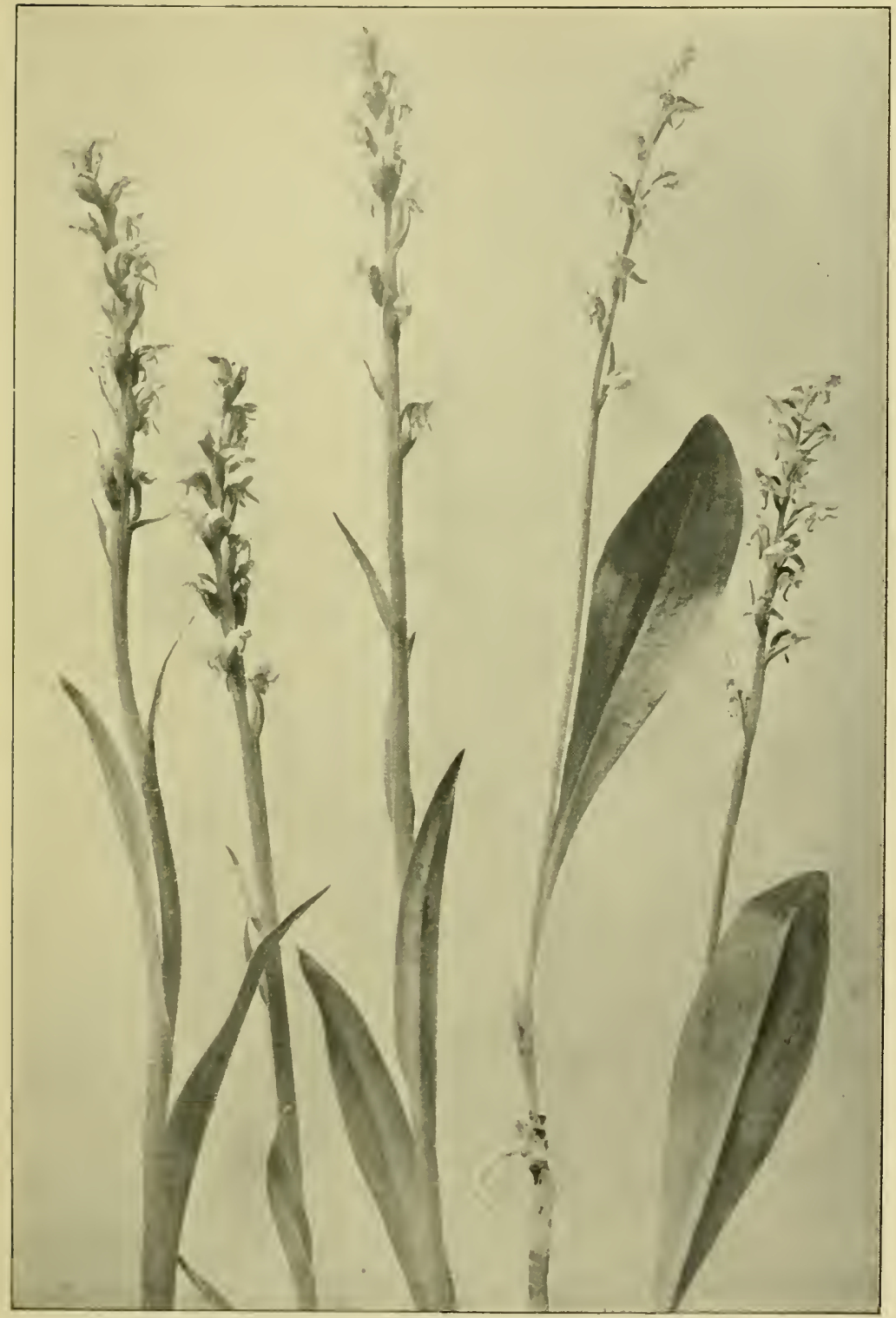

LEAFY ORChIS (Habenaria hyperborea)

Smald Orcins (Ilabenaria obtusata) 



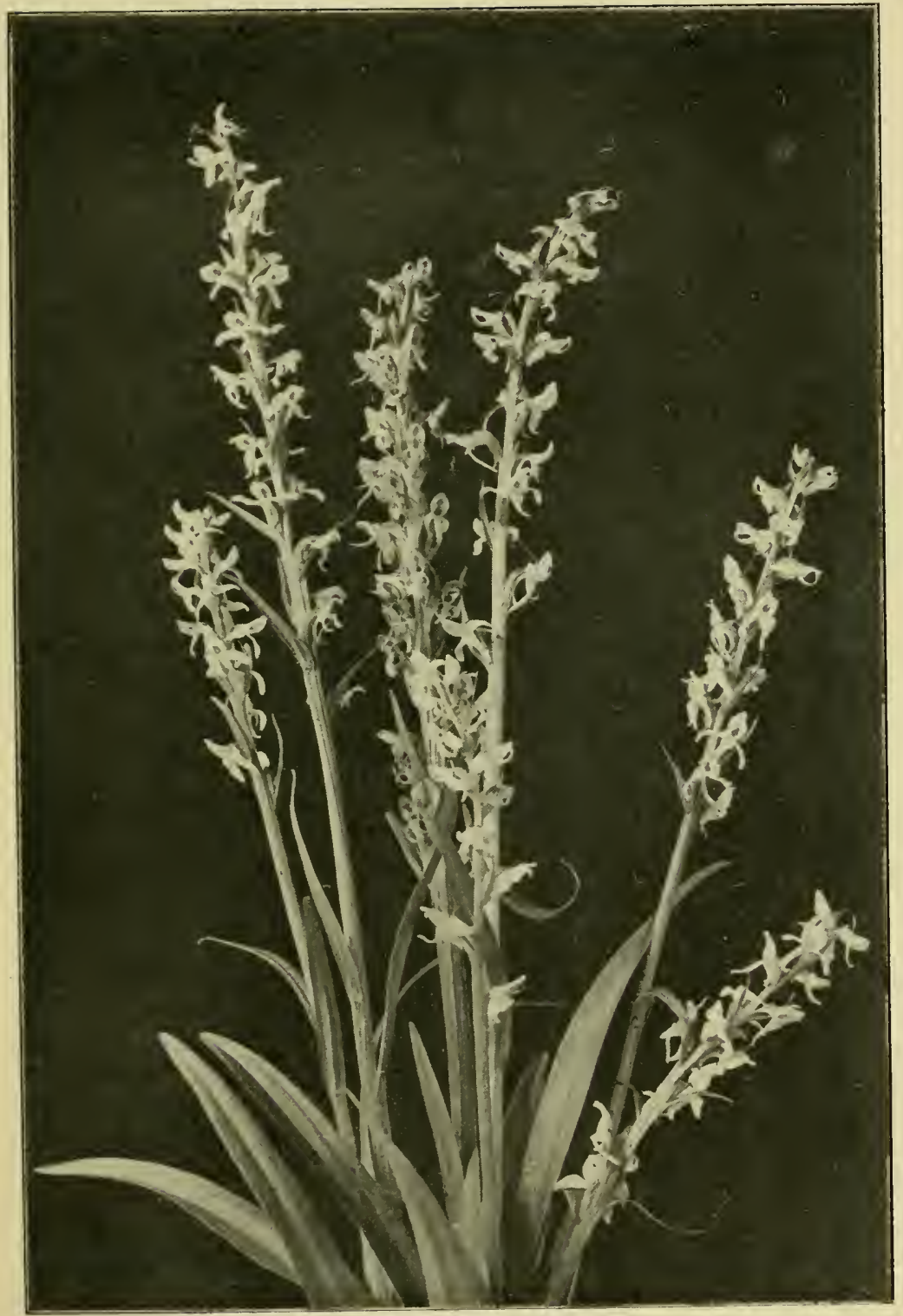

White BOG ORChis

(Habenaria dilatuta) 

This green Orchis somewhat resembles H. obtusata, but may easily be clistinguished by the fact that it has several leaves growing up on and clasping its stem, which is also decidedly stouter than the stem of the preceding species. The Leafy Orchis grows in the open woods, preferring a moist spot. It has many flowers on each stalk, and they grow closely set together.

\section{WHITE BOG ORCHIS}

\section{Habenaria dilatata. Orchid Family}

Stems: thick, fleshy, one to two feet high. Leaves: lanceolate, obtuse. Flowers: spike long, white, very fragrant, bracted; sepals ovate, obtuse ; lip entire, dilated; anther-sacs parallel; glands close together; stigma with a trowel-shaped beak.

To walk through the woods, deep and dark, where the trees and shrubs grow densely side by side and flowers are few and far between; and then to suddenly emerge into the open, where the sun's light is flooding across the marsh-lands, carpeted by myriads of tall White Bog Orchis, is a pleasure so dazzling that, once experienced, it will never be forgotten.

Fragrant as hyacinths, these exquisite snowy orchids grow to a great height in the mountain marshes, and so beautiful and wonderfully delicate are their blossoms that travellers long to transplant them to some lowland garden, in order to see their velvety spikes grow and grace civilization with a woodland loveliness. But as a rule this experiment is tried in vain, for few of the orchicls will flourish so far from their native soil.

Words fail to truly clescribe these plants of almost unearthly beauty. From their dainty petals

$$
\text { "Odours ascend, }
$$

Spreading themselves through the serener air

Where gentle breezes strive to bless,

And all God's world knows happiness."

Those who find them will always love and treasure them. 
There is another very large species of the same genus, much resembling $H$. dilaterta, but taller, and sometimes growing to the immense height of five feet. It is called H. lcucostachys, or Giant Orchis, and, like the Bog Orchis, has snow-white fragrant flowers.

\section{MOUNTAIN LADY'S SLIPPER}

\section{Cyprifudium pusserinum. Orchid Family}

Stems: stout, leafy. Leaves: ovate, acuminate. Flowers: solitary or two; petals and sepals pale green; lip dull white, veined, and with bright red spots; anther ovate-triangulate, yellow with red spots. Fruit: capsule drooping.

This is the small white Lady's Slipper, and its discovery in the mountains is of sufficiently rare occurrence to be quite an event in the history of the day to the ordinary traveller. It is usually in shady places, where the soil is moist and rich, that these little velvety orchids are found. The dull white sacs, hairy inside and spotted with bright red, are quite unmistakable; the stalks are leafy and usually bear only a single terminal flower, though occasionally two shell-like blooms aclorn the fat juicy stem, one at its apex and the other a couple of inches lower down.

There is a rich tropical beauty about orchids strongly suggestive of the Orient. They do not seem to be at home in the stern wild mountain fastnesses, but rather to belong to a world of cloudless skies and riotous foliage, where exotic flowers are set like jewels in the lavish luxuriance of the clement zone.

\section{WHITE TWISTED-STALK}

Streptopus amplexifolius. Lily Family

Rootstock short, stout, horizontal, covered with thick fibrous roots. Stems: glabrous, branching below the middle. Leaves: acuminate at the apex, cordalle-clasping at the base, glaucous beneath. Flowers: one to two, greenish-white. Fruit: recl oval berry, many-seeded. 
PLATE XXXVI

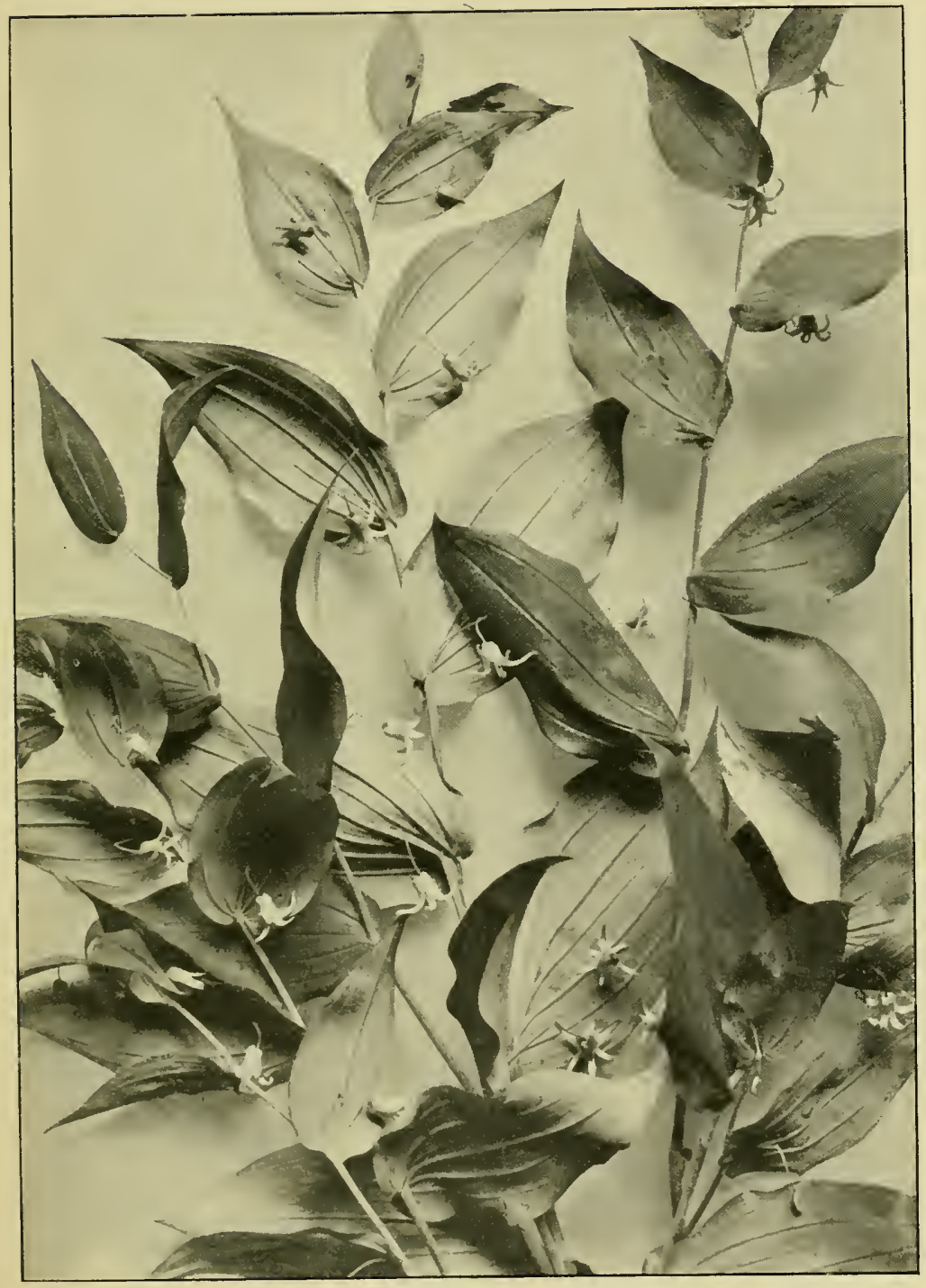

White TWISTED-STALK

(Streptopus amplexifolius) 



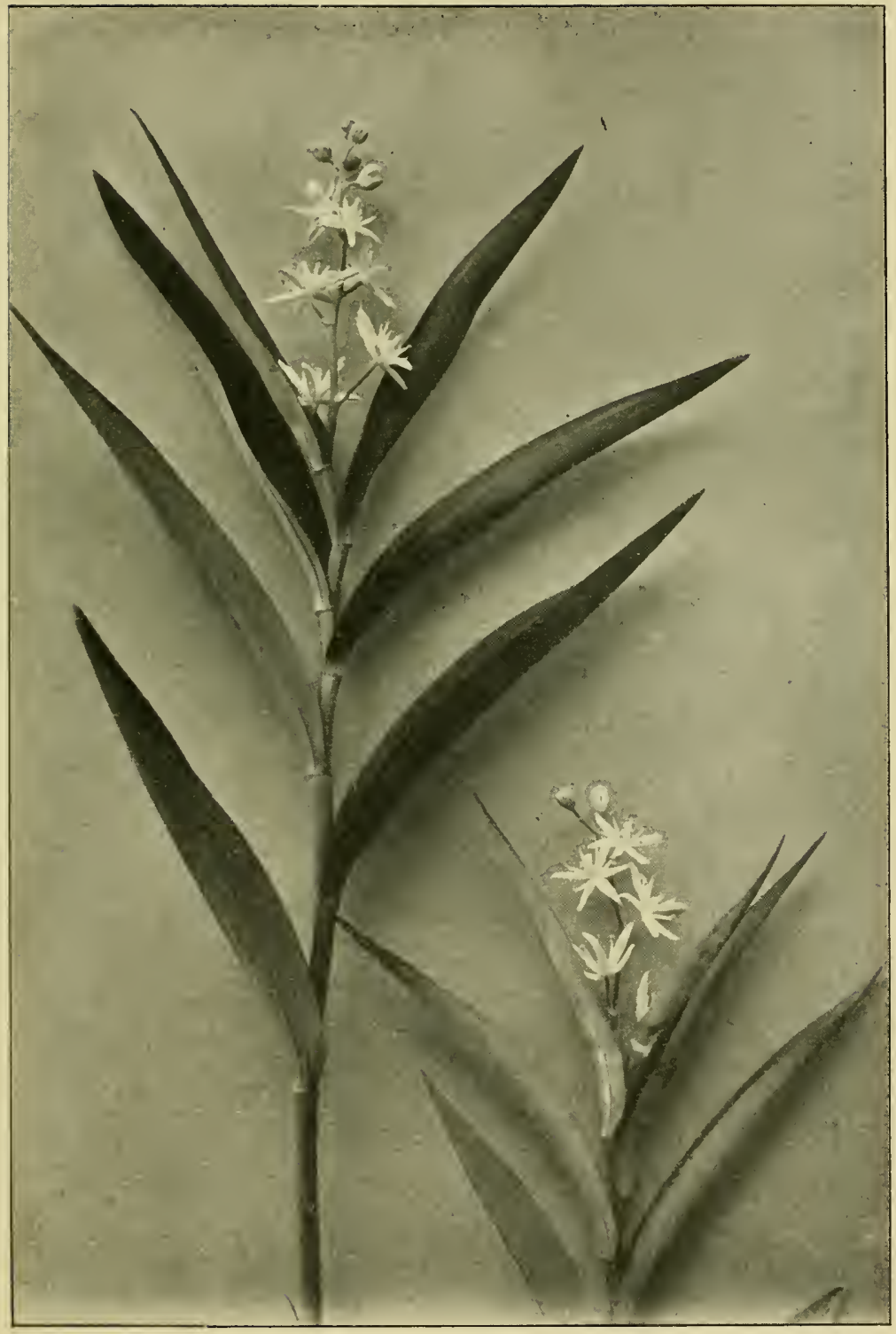

SPIKENARD

(Smilacina stellata) 

This Twisted-stalk is a large plant with many clasping, pointed leaves growing all the way up on both sides of its long branching stems, with one solitary leaf at the apex. These leaves are handsome, green and glossy on the top, with strongly marked veins, and are covered with a whitish bloom on the under side. Looking at the plant from above it appears to bear no flowers at all, but turn over its stems and you will find beneath each leaf one or two tiny greenish-white bells, hanging on sharply bent thread-like stalks that spring from the axils of the leaves; these flowers in time turn into bright red oval berries.

The name Twisted-stalk is derived from its abruptly bent flower stems.

For S. roscus, S. brevipes, and S. curvipes see the Pink to Red Section.

\section{SPIKENARD}

Smilacina stellata. Lily Family

Stems: stout, erect, or somewhat zigzag. Leaves: lanceolate, sessile, somewhat clasping, acute, acuminate at the apex, rather concave. Flowers: raceme sessile or short-peduncled, several-flowered. Fruit: bright red berry dotted with purple.

Large colonies of this pretty Spikenard, which to ordinary eyes looks like a wild Lily-of-the-Valley, grow near the banks of mountain streams and in the moist meadows. It is a lovely plant that grows up very stiff and straight out of the ground, and has stout stems which are leafy all the way from the base to the slender flower racemes. These racemes are composed of from five to fifteen little starry blossoms, each one having a white six-parted perianth. The leaves are of a whitish-green hue. 


\section{FALSE SOLOMON'S SEAL}

\section{Smilacina amplexicanlis. Lily Family}

Stems: stout, ascending, leafy: Leaves: oval, clasping, acuminate, their margins minutely ciliate. Flowers: panicle densely flowered; perianthsegments oblong. Fruit: red aromatic berry, flecked with purple.

The long leafy wands of the False Solomon's Seal are exceedingly attractive, with their handsome terminal clusters of little creamy blossoms that look like full feathery plumes as they wave gently to and fro in the soft summer breeze and cast their faint fragrance across the woods. Very handsome, too, are the leaves of this large plant. Why it is banned with such a base name as False Solomon's Seal I do not know. There is nothing "false" about it except its name; and while its luxuriant broad foliage resembles that of both the True Solomon's Seal and the Twisted-stalk, still its flowers are entirely different, growing in close terminal panicles, whereas those of the other plants mentioned grow in small individual bells from the axils of the leaves. However, False Solomon's Seal is its name, and by such it is known all over the world.

\section{QUEEN-CUP}

\section{Clintonia uniftora. Lily Family}

Stems: villous-pubescent. Leaves: few, lanceolate, acute, attenuate helow to a sheathing petiole. Flowers: solitary; peduncle scape-like, shorter than the leaves; perianth campanulate, of six segments, white; style equalling the stamens. Fruit: blue berry.

An exquisite six-parted white flower with a heart of gold, found growing in the shady wools. Its leaves fairly carpet the ground in the localities where it abounds; they are large and grossy and resemble those of the I ily-of-the-Valley. The stems, which usually bear only a single flower, are very hairy. Thoreau has complained bitterly that this beautiful dweller of 


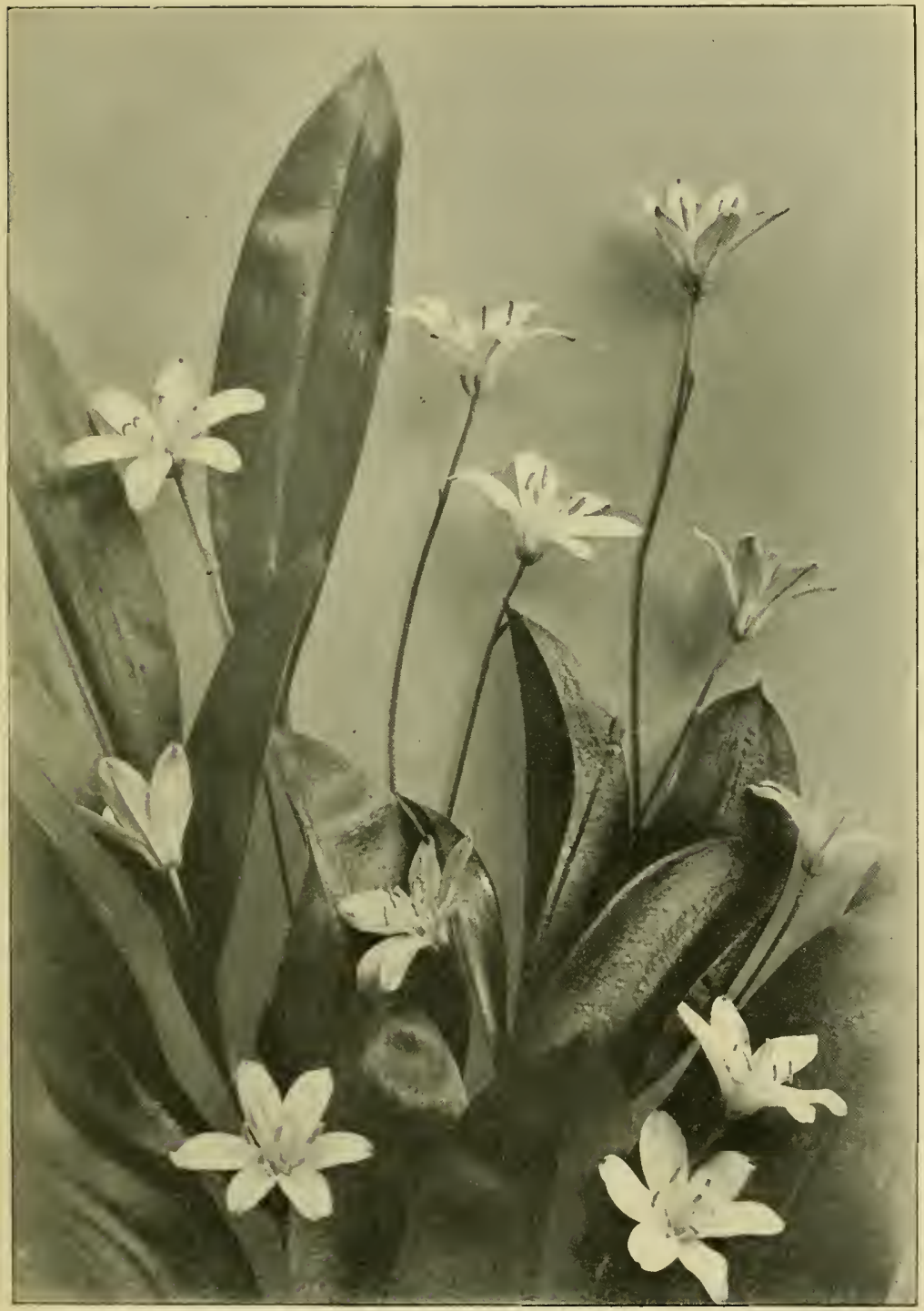

QuenN-CuP

(Clintonia uniflora) 

PLATE XXXIX

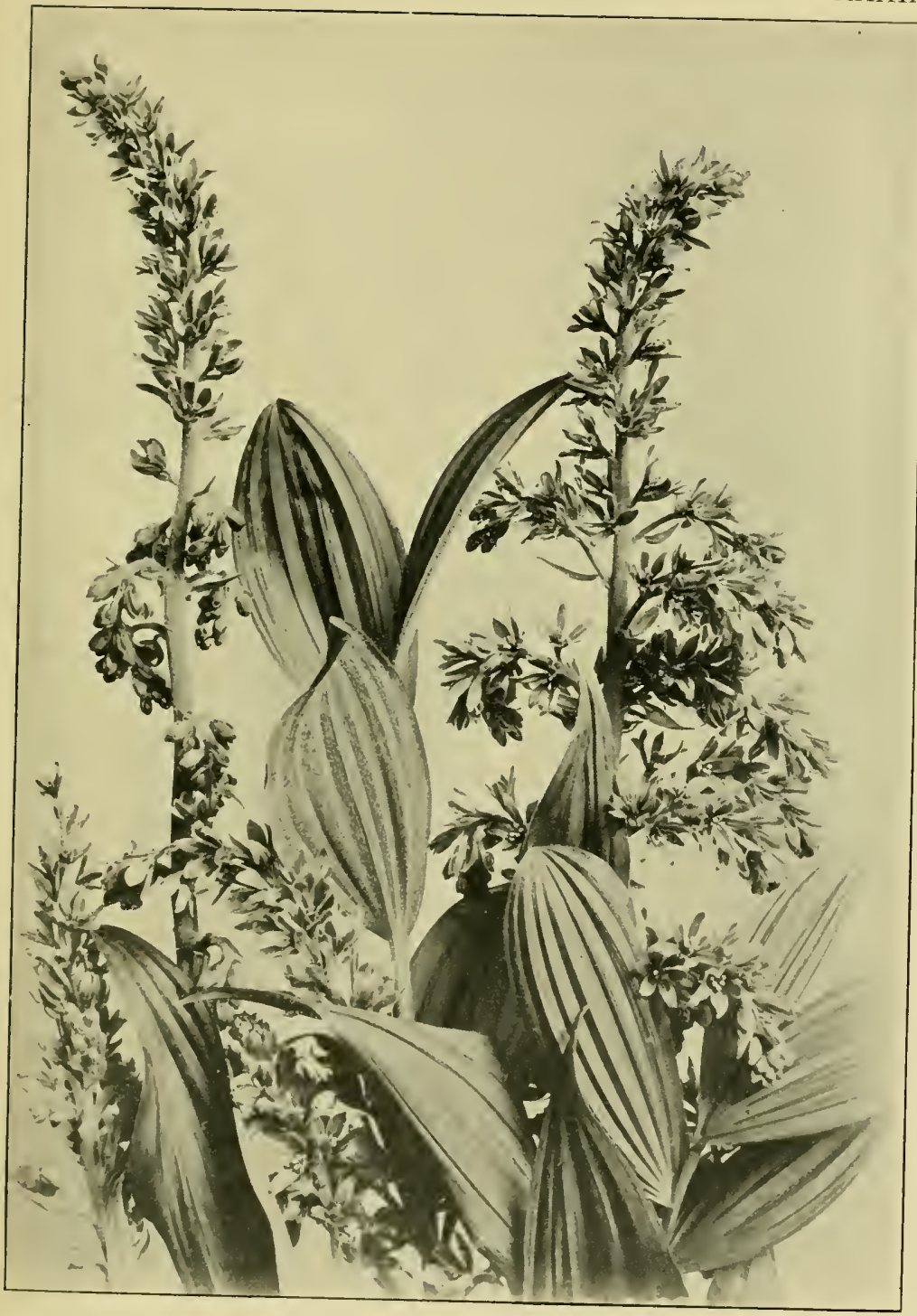

False Hellebore

(I'eratrum viride) 

the forest should be called after so prosaic an individual as the Governor of New York, and soundly berates Gray for the fault; but may not Clinton, the man of affairs, statecraft, and finance, have had an artistic side to his character? May he not have been a true lover of Nature and an ardent aclmirer of the splendid throng of amazing and mysterious beauties that enrich with the perfume of their presence the land of the alpine flower-fields?

I feel that a great honour has been conferred upon me in that I have been permitted to name this lovely plant - Queencup. Hitherto it has been nameless in the English language, and it seems to me that no more fitting title could be bestowed upon the Clintonia uniflora, with its great shining leaves, amongst which are set the pure white chalices of its blossoms, than Queen-cup, - the queen of all the snowy flower-cups of the alpine forests.

\section{ASPHODEL}

\section{Toficldia glutinosa. Lily Family}

Stems: viscid-pubescent with black glands, bearing two to four leaves near the base. Leaves: basal ones tufted. Flowers: terminal racemes oblong, the upper flowers opening first, becoming longer in fruit; involucral bracts minute, united at the apices, borne just below the flower; perianth-segments oblong, obtuse, membranous. Fruit: seeds tailed at each end.

A traveller cannot pick the long spikes of tiny white blossoms which belong to this plant without at once recognizing its name by the exceelingly sticky and hairy nature of the stems. The Iatin designation glutinosa exactly describes it. The Asphodel grows along the banks of streams and in wet places. See Plate XXXII. 


\section{FALSE HELLEBORE}

\section{Veratrum viride. Lily Family}

Stems: stout, tall, very leafy, Leaves: acute, strongly veined, shortpetioled, sheathing, the upper ones successively narrower, those of the inflorescence small. Flowers: panicles long, pubescent, densely manyflowered, its lower branches spreading.

This is by far the largest and handsomest green-flowered plant which grows in the mountains. Its foliage is immense in size, bright green, and the leaves have a peculiar plaited appearance. In the early spring the stout solid spears of the False Hellebore push their way up through the soil and soon begin to unfold with the increasing warmth of the sun's rays. Then the long stiff spikes and graceful pendent tassels of flowers commence to lengthen and unfold, yellowish at first, and later on becoming greener. The flowers are composed of six petals and have six whitish stamens.

Burton in his Anatomic of Mclancholy refers to the alleged curative properties of the Hellebore as an antidote for madness.

"Borage and hellebore fill two scenes,

Sovereign plants to purge the veins

Of melancholy, and cheer the heart

Of those black fumes which make it smart."

Yet according to the principle that those herbs which cure may also kill, the Hellebore is best known to us as a very poisonous plant.

\section{STENANTHIUM}

Stenanthium occidentale. Lily Family

Bulb oblong-ovoid, coated. Stems: slender, erect, glabrous. Leaves: few, linear, lanceolate, acuminate. Flowers: raceme simple, flowers campanulate, nodding, segments of the perianth brownish-green; loracts somewhat scarious; pedicels slender, spreading, longer than the bracts. Fruit: seeds linear, flat, wingeel. 


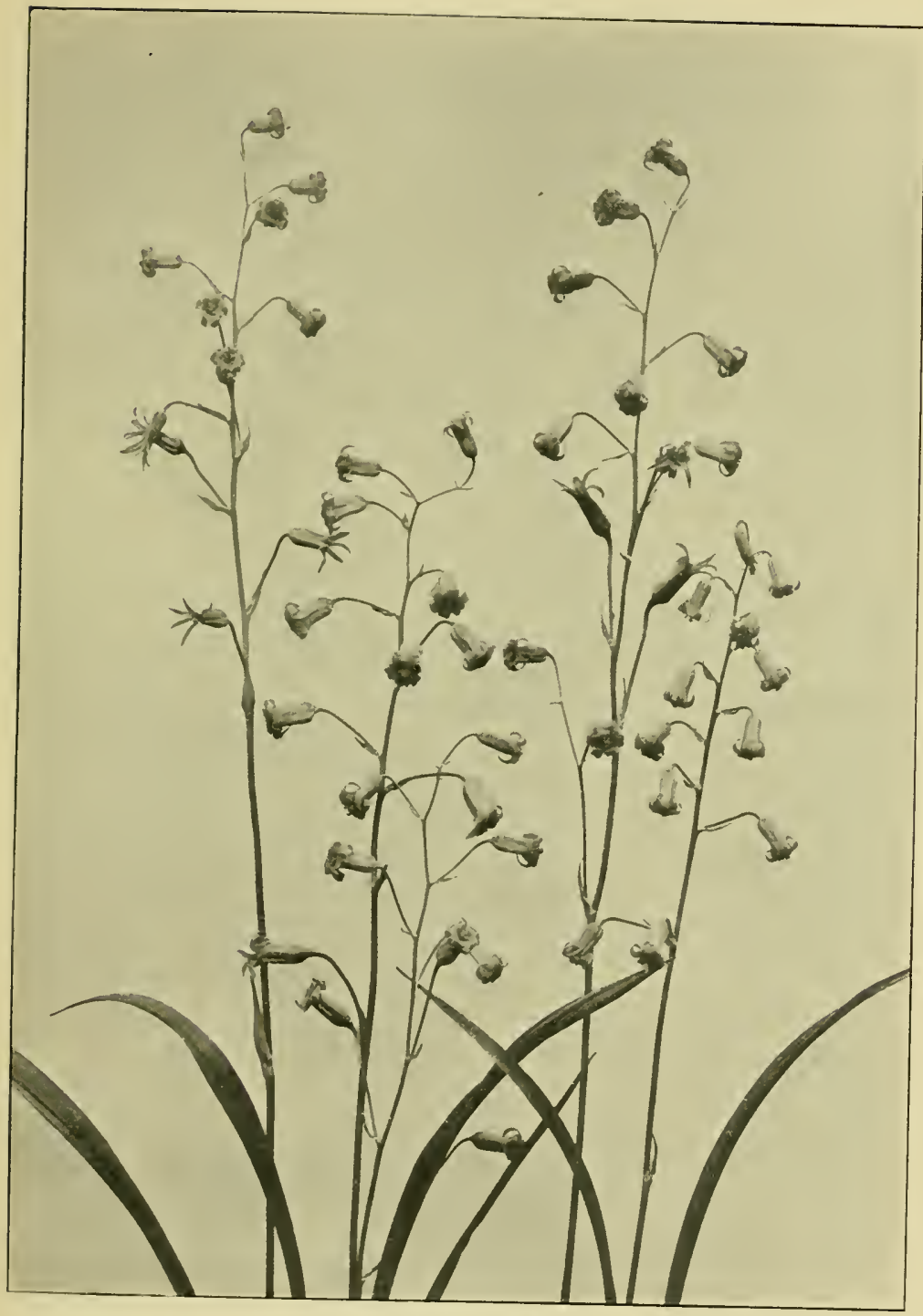

STENANTIIUM

(Stenanthinm occidentale) 



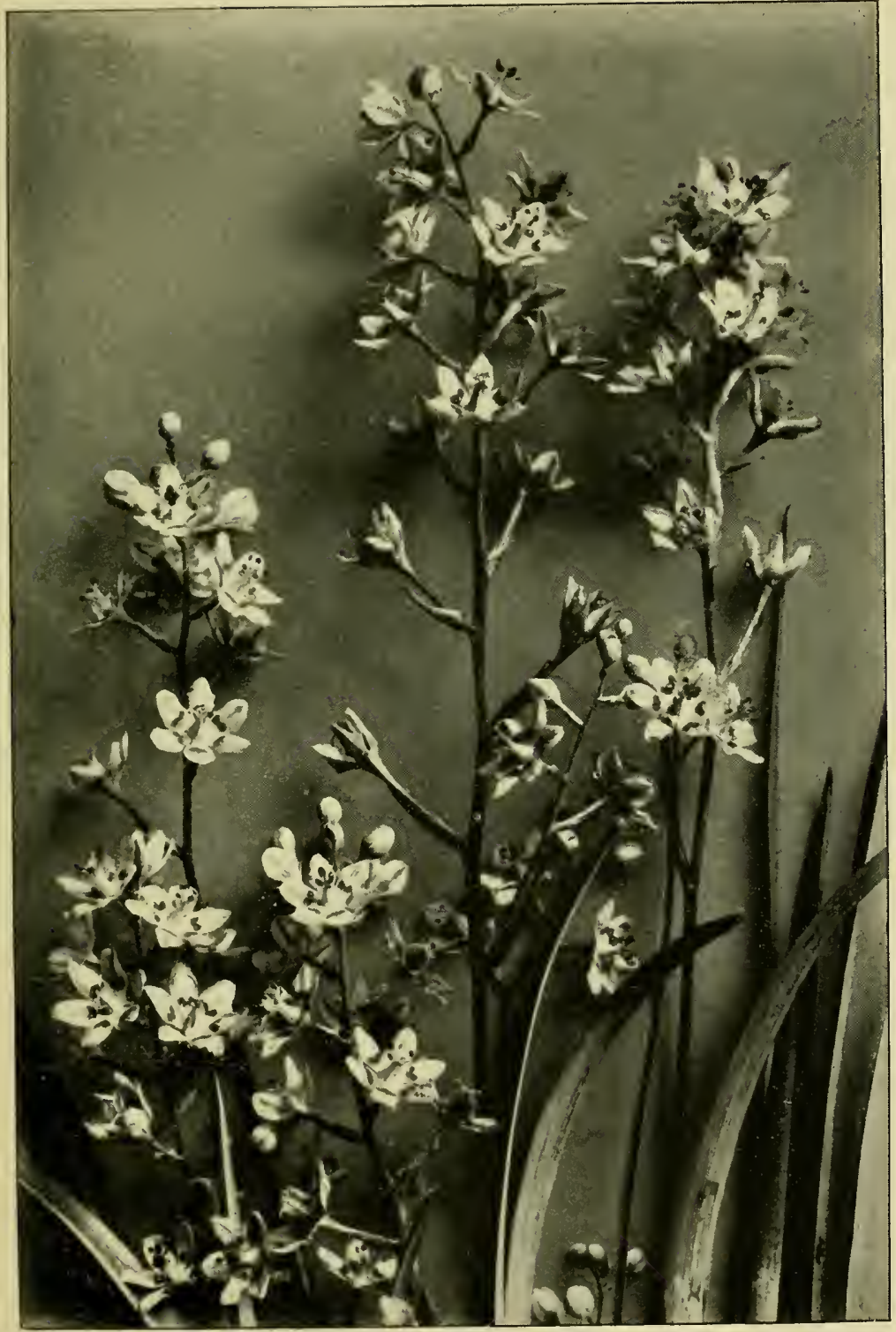

Tall Zygadene.

(Zygadenus elegans) 

This plant grows only in shady places and is tall, with many brownish-green bells nodding on its slender stalks. It has very narrow ribbon-like leaves growing from the base and also up the stems.

\section{TALL ZYGADENE}

\section{Zygadenus elegans. Lily Fanily}

Bulb ovoid, membranous, coated. Stems: slender. Leaves: very glaucous, narrow; bracts long-keeled, lanceolate, rather large. Flowers: in a single raceme, or a large panicle, its branches slender, ascending, the perianth adnate to the base of the ovary, its segments broadly oval, the inner abruptly contracted to a short claw, gland obcordate. Fruit: seeds oblong, angular.

A tall attractive plant whose branching stems are covered by many round creamy flowers splashed with green. These flowers are six-parted and have a number of brown-tipped stamens clustered about the large green base of the pistil. The capsule, or dry fruit, which develops as the floral leaves die and drop off, is three-lobed and very large. The leaves of the Tall Zygadene are long and narrow and are covered with a whitish bloom.

$Z$. acncnosus, or Poisonous Zygadene, is a slightly shorter, smaller species of this genus, also frequently found in the mountain regions. Its yellowish-green flowers grow closely together and it has roughish leaves. So poisonous is this plant that animals frequently die from the effects of eating it. 



\title{
MOUNTAIN WILD FLOWERS OF AMERICA
}

\author{
Section II \\ PINK TO RED FLOWERS
}





\title{
Section II
}

\section{PINK TO RED FLOWERS}

\author{
Flowers that are pink to red, or ociasionally so, but not \\ described in this Section
}

\begin{abstract}
$P_{A G E}$
Wind-flower . . . . Anemone multifida (White to Green Section) . . . 4 Stony Rock-cress. . . . Arabis Holbollii (White to Green Section) . . . . I5 Alpine Rock-cress . . Arabis confinis (White to Green Section) . . . I5 Drummond's Rock-cress . Arabis Drummondii (White to Green Section) . . I6 Spring Beauty . . . Claytonia scssilifolia (White to Green Section) . . 28 White Geranium . . . Geranium Richardsoni (White to Green Section) . . 3I Alsatian Clover . . . . Trifolium hybridum (White to Green Section). . . $3^{I}$ Tellima . . . . . . Tellima grandiftora (White to Green Section) . . . 50 Alpine Aster . . . . Aster alpinus (White to Green Section) . . . . . 68 Yarrow . . . . . Achillca lanulosa (White to Green Section) . . . 74 Sweet Androsace . . . Androsace Chamajasme (White to Green Section) - 90 Star-flower . . . . Tricntalis Americana (White to Green Section) . . 90 Buckbean . . . . . Menyanthes trifoliata (White to Green Section) . . 95 Tall Eriogonum . . . Eriogonum umbellatum (White to Green Section) . . Ioo Alpine Bistort . . . . . Polygonum vivifarum (White to Green Section) . . Ioo Mountain Larkspur. . . Delfhinium Broz'nii (Blue to Purple Section) . . . I9I Wavy-leaved Thistle . . Cnicus undulatus (Blue to Purple Section) . . . . 220 Large Purple Beard-tongue Penstemon Menzicsii (Blue to Purple Section) . . . 243 Wild Canada Mint . . Mentha Canadensis (Blue to Purple Section) . . . 248
\end{abstract}

\section{WESTERN COLUMBINE}

\section{- Aquilegia formosa. Crowfoot Family}

Stems: branching from a simple, fleshy, fusiform root. Leaves: lower ones triternate on long petioles, upper ones sessile or reduced to simple bracts; leaflets broadly cuneate, three-cleft. Flowers: red, pendulous in anthesis; sepals spreading or reflexed, abruptly narrowed to a short claw; spurs same length as sepals. 
A large gaudy flower of which it has been said:

"The graceful columbine, all blushing red,

Bends to the earth her crown

of honey-laden bells."

The Western Columbine does not seek the light dry soil amongst the rocks, as do its sisters, the Yellow and the Blue Columbines, but prefers a moist habitat, where its brilliant pendulous blossoms make the valleys gay.

It has five bright red and gold petals, growing alternately with its five red sepals. These petals, shaped like inverted cornucopias, are usually edged as well as lined with yellow, their upper ends being narrowed to terminal tubular spurs. Linnzeus gave this plant its generic name, derived from the Latin aquila, owing to the fancied resemblance of its spurs to the claws of an eagle; while Columbine is taken from columba, "a dove," and refers to the resemblance of its nectaries to a circle of cloves in a ring around a dish, which was a favourite device amongst sculptors and painters in ancient times. The numerous stamens and long slender styles of the pistils protrude like pretty golden tassels from each flower. The foliage of this tall plant, which usually grows from two to three feet high, is very abundant and fern-like; dark green on the top, and pale and whitish underneath. The larger leaves grow on long foot-stalks and are divided into three leaflets, which in their turn are three-to-five lobed and have unequally toothed edges.

There are not very many really red mountain wild flowers, and therefore the traveller takes an especial delight in finding the Western Columbine, since, like Eugene Field, he loves a blossom of "any colour at all so long as it's red." It is a plant extremely attractive to bees, butterflies, and bircls, which come to sip its sweets. 


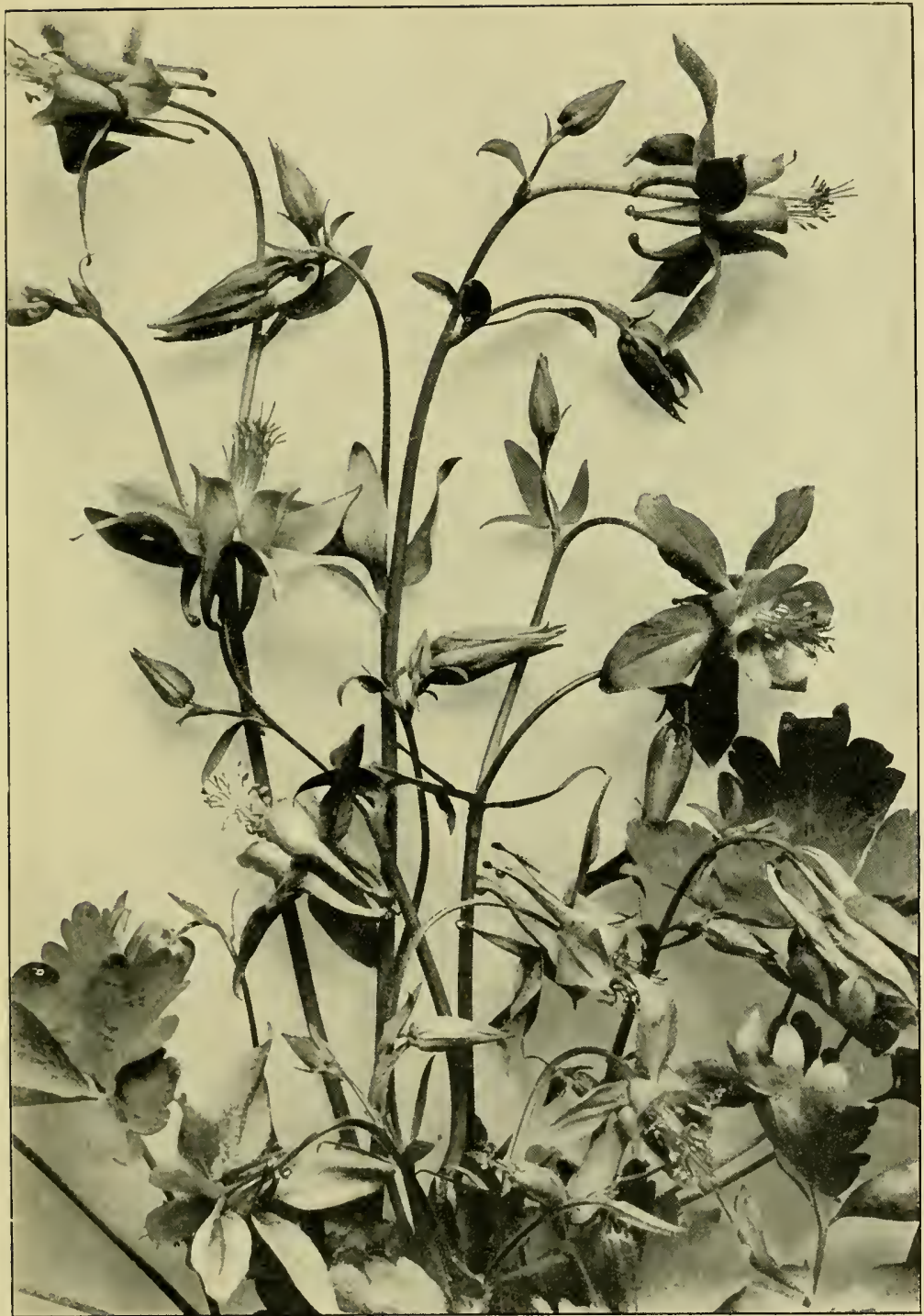

Western Columbine

(Aquilegia formosa) 



\section{WILD BLEEDING-HEART}

\section{Dicentra formosa. Fumitory Family}

Stems: from the apex of thick, almost naked, creeping rootstocks. Leaves: twice or thrice ternately compound, the ultimate divisions narrow and incisely pinnatifid. Flowers: pale magenta, in compound racemes at summit of scapes; corolla ovate-cordate, with connivent spurs; petals united up to and above the middle.

This plant resembles, in miniature, the lovely pink and white Bleeding-heart so popular in old-fashioned gardens; but its clull magenta-pink flowers are not nearly so attractive in appearance as those of its beautiful cultivated cousin. The only charm of the wild species lies in the grace of its slender stems, which bear numerous pendent heart-shaped blossoms along their clrooping lengths, and its finely dissected foliage.

\section{CAROLINA CRANE'S-BILL}

\section{Geranium Carolinianum. Geranium Family}

Stems: erect, much branched from the base. Leaves: petioled, reniformorbicular in outline, deeply cleft into five to nine oblong, cuneate, lobed segments. Flowers: in compact clusters; petals pink, obcordate, equalling the awned sepals.

This wild Geranium is very like the Herb Robert, and has the same dull pink flowers veined with deep rose. The Greek name of the plant means "a crane," and the common name Crane's-bill denotes the long grooved beak composed of five styles that cohere at the top. The calyx is formed of five pointed sepals, and the corolla of five indented petals. The whole plant is covered with fine gray hairs and has an extremely strong smell, caused by a resinous secretion. Its leaves are roundish in form and deeply cleft; the long stalks are brittle and quite red where exposed to the sunlight. Sometimes the flowers are white. 


\section{RED CLOVER}

Trifolium pratense. Pea Family

Stems: ascending, somewhat hairy; pistules broadly lanceolate, membranaceous, nerved, setaceously acuminate. Leaves: leaflets obcordate, nearly entire. Flowers: heads orate, dense, nearly sessile, bracteate; teeth of the calyx setaceous, hairy, the lower one much longer than the other four; petals purple-red, all united into a tube at the base. Not indigenous.

Thoreau speaks of the fields blushing with Red Clover "as the western sky at evening." Every one knows the Clover. Every one has walked ankle-deep in meadows rich with its red flowers. Some of us are even fortunate enough to "live in clover," — but not all! It is a quaint conceit of the Red Clover to fold its leaves in sleep each night, the two side leaflets drooping downwards together and the terminal one bowed over them.

The name Clover probably comes from the Latin clase, meaning "club," and refers to the possible resemblance between the trefoil leaf and the three-headed club of Hercules. The "clubs" on playing cards are, no doubt, also an initation of the clover leaf.

\section{MACKENZIE'S HEDYSARUM}

\section{Hedyarum dackenzii. P'ea Family:}

Stems: suberect, simple or branched, minutely pubescent. Leaves: five to eight pairs, oblong. Flowers: seven to thirty, loosely flowered; bracts subulate; teeth of the calyx as long as the tube.

A bright rose-magenta wild Pea that grows to a height of two feet in the mountain meadows. It is a large, spreading, handsome plant. 
PLATE XLIH

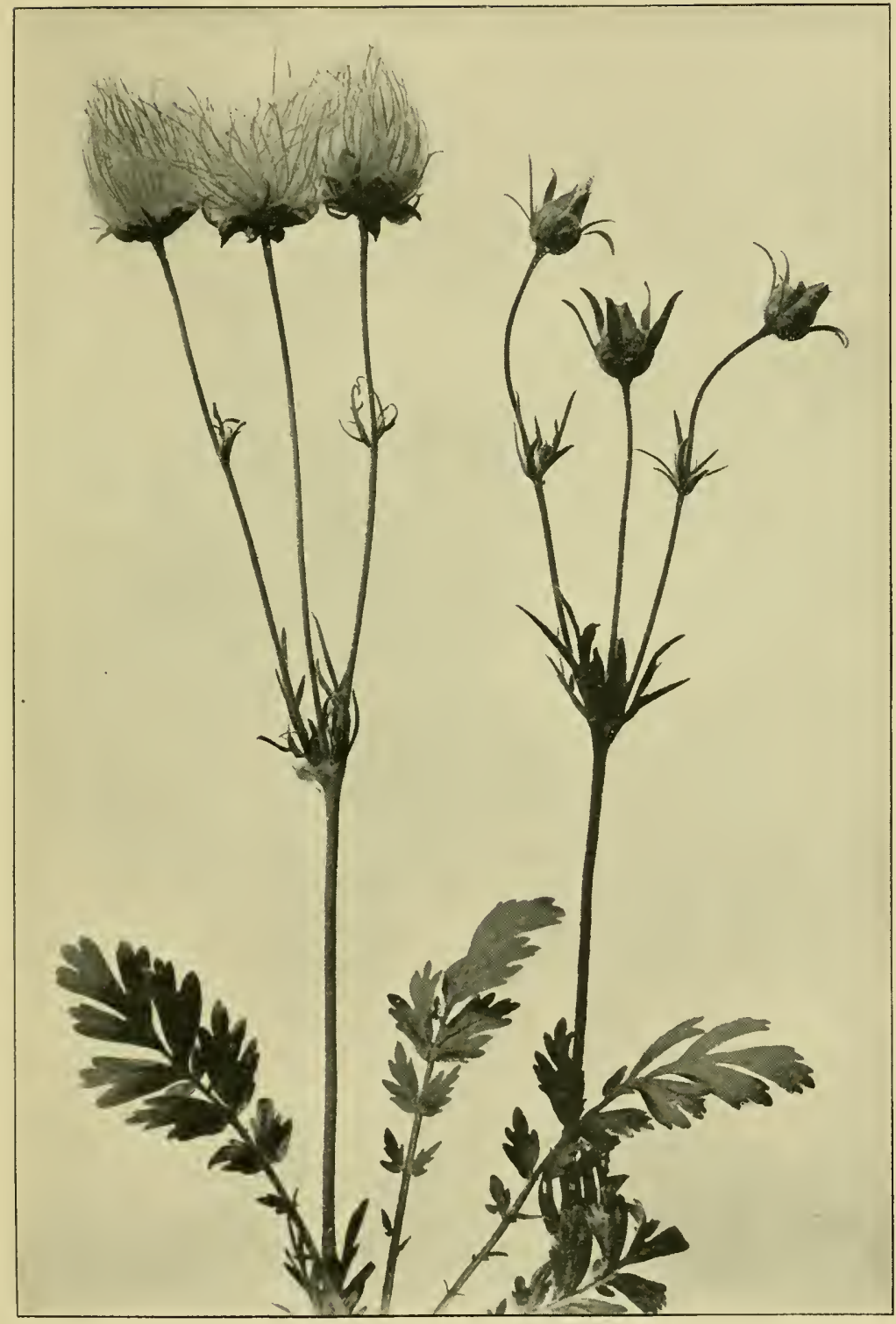

Long-Plumed Avens

(Geum triflorum) 



\section{ARCTIC RASPBERRY}

\section{Rubus arcticus. Rose Family}

Stems: erect, branched at base. Leaves: trifoliolate; leaflets sessile, rhombic-ovate, unequally serrate. Flowers: solitary; sepals acute, equalling the obovate entire petals. Fruit: light red, of several drupelets, edible.

A dwarf alpine Raspberry, about six inches high, that grows at an altitude of $S 000$ feet. It has a few large threeparted leaves and one or two rose-pink flowers composed of six long, widely separated petals. The long thin roots strike straight down into the earth, and therefore when you attempt to pick one of these little plants it usually comes up altogether out of the ground in your hand. The Arctic Raspberry has no prickles.

\section{LONG-PLUMED AVENS}

\section{Geum triflorum. Rose Family}

Stems: scape simple, three-flowered at the summit. Leaves: basal ones tufted, petioled, interruptedly pinnate, with many small leaflets interspersed among the numerous obovate larger ones; leaves of the scape two opposite, small, sessile pairs. Flowers : of five pale purplish-pink petals surrounded by a persistent red calyx, five-bracteolate and five-lobed; bractlets linear, slightly longer than the lanceolate, acute, erect lobes. Fruit: head sessile; style filiform and strongly plumose.

A very curious plant. Its general appearance is that of bearing three large dull red buds on a three-branched red stem, with a number of little red bracts clustered at the fork; for the pale pink or yellowish petals are so snugly hidden away within the calyx that you do not observe them at a casual glance. The closed calyx forms these fat buds, which have five slender reflexed bracts set between their lobes, and from their pointed tips protrude a number of yellow stamens.

When the petals and sepals fall off the long plumose tails that adorn the ripened heads of the Avens are exceedingly attractive.

Many long finely cut leaves grow at the base of this plant. 


\section{ROSEWORT}

Sedum frigidum. Orpine Family

Stems: erect, simple, glabrous. Leaves: oval, obtuse at the apex, dentate. Flowers: cyme terminal, dense; petals longer than the oblong narrow sepals; staminate flowers with eight stamens, the pistillate ones with four carpels.

The small purplish-red flowers of this short thick plant are set in a cluster at the top of the stems, which are covered with many small leaves. It grows in the crannies between the rocks and on stony slopes.

\section{GREAT WILLOW-HERB}

Epilobium angustifolium. Evening Primrose Family

Stems: erect, simple or branched, glabrous. Leaves: alternate, lanceolate, entire, pale beneath, acute at the apex, narrowed at the base, thin. Flowers: magenta, in terminal spike-like racemes; petals four, entire, spreading.

The tall strong stems of this striking plant rise to an average height of three feet, though frequently taller, and terminate in long racemes of bright purplish flowers, in which the number four is conspicuous, each one having a very long calyx-tube divided into four segments and four large, rounded, wicle-open petals. The four-cleft stigma at the apex of the long style is extremely prominent. The micl-ribs of the leares, the stems, the buds, and the calyx-tubes are all a clull red; and when the seed ripens the long narrow vessels burst open lengthwise and send afloat in the air clouds of white silly tufts, to each of which is attached a seed that ultimately falls to earth secking some new spot favourable to its development.

The name Efilobimm signifies "upon a pod," and probably refers to the fact that the flowers grow on the ends of the long pods. Willow-herb refers to the fact that the leaves resemble those of the Willow. 
PLATE XLIV

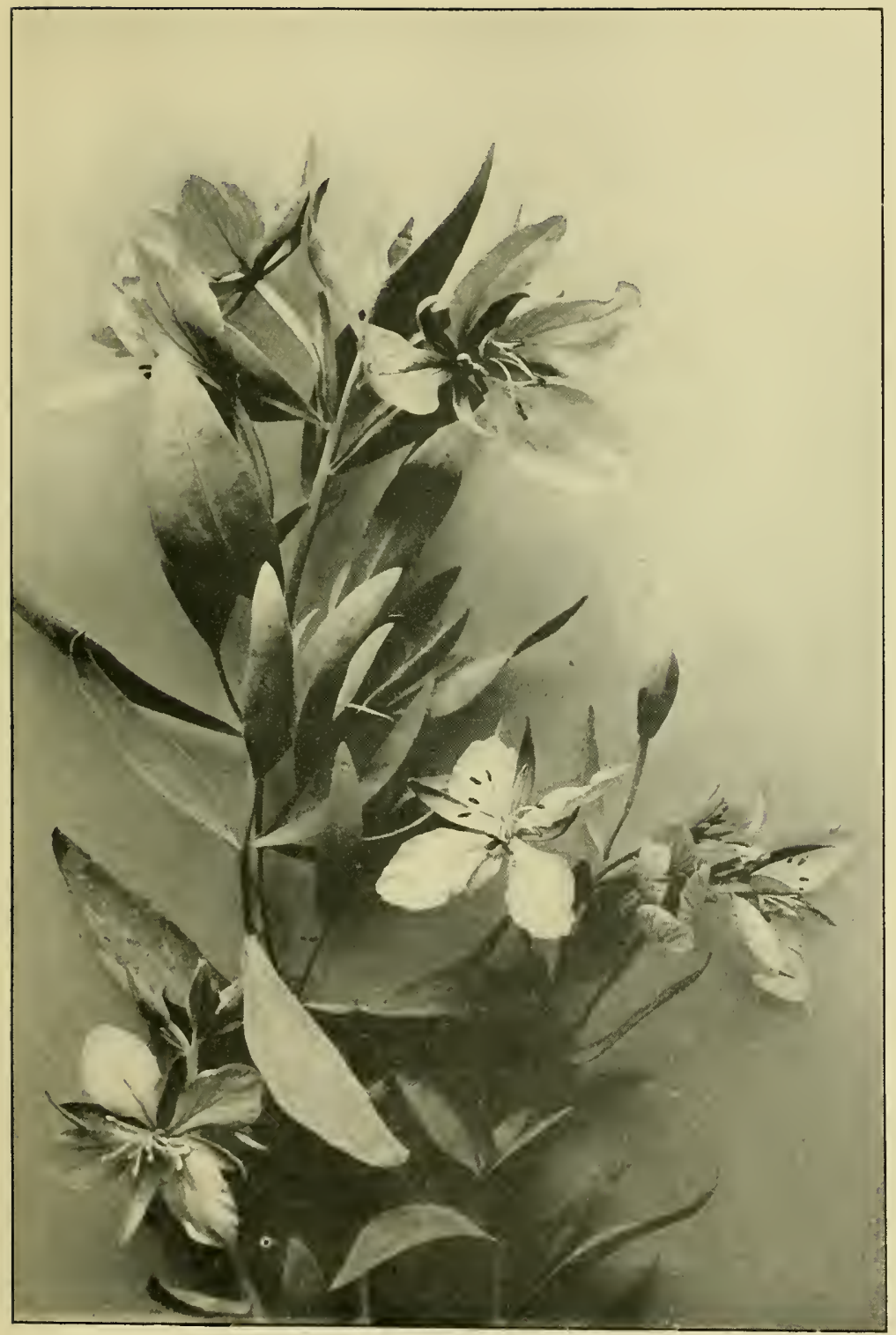

WATER WILLOW-HERB

(Epilobium latifolium) 

Wild Fire, or Fire Weed, is another common name for this plant, and a very appropriate one, too, for it is marvellous how quickly these stately, handsome flowers will cover over and beautify those tracts of country that have been charred and desolated by forest fires.

"Strange flower, thy purple making haste

To glorify each blackened waste

Of fire-swept land

Is with a blessed meaning fraught,

And we - when pain hath fully wrought -

Shall understand."

E. angustifolium i'ar. cancsccns, or Pink Willow-herb, is another species resembling the foregoing one, but having lovely pale pink flowers marked by rose-coloured veins.

\section{WATER WILLOW-HERB}

Epilobium latifolium. Evening Primrose Family

Stems: erect, branching. Leaves: sessile, entire, lanceolate, acutish at both ends, thick. Flowers: magenta, in leafly-bracted racemes; petals entire; stigma four-lobed.

A very handsome species of Willow-herb, which grows in wet places and marshes, or near water. It may always be recognized by its large bright magenta flowers and the glaucous appearance of the stems and leaves, - that is to say, by the whitish bloom which covers them. The leaves are also thick and very soft.

\section{ALPINE WILLOW-HERB}

Epilobium anagallidifolium. Evening Primrose Family

Stems: low, tufted, nodding at the apex. Leaves: oblong, entire, obtuse at the apex. Flowers: few, axillary, clustered at the apex, nodding; stigma entire. Fruit: seeds smooth, short-beaked, coma dingy white.

A tiny dwarf plant, from two to six inches high, growing on lofty summits. It has small magenta or sometimes white 
flowers, which nod at the top of the slender single stems, up which a few pairs of little oblong leaves grow. It has been found at the immense altitude of 10,000 feet.

\section{HORNEMANN'S WILLOW-HERB}

Epilobium Hornomanni. Evening Primrose Family

Stems: erect, simple or nearly so. Leaves: short-petioled, ovate, broadly obtuse at the apex, narrowed at the base, entire or remotely denticulate, thin. Flowers: few in the upper axils; stigma entire. Fruit: capsules long; seeds papillose, nearly beakless.

A common species of Willow-herb that grows about eight inches high, bears small purplish-pink or white flowers that are strongly veined, and has very long slender capsules, or seed vessels, on its reddish stalks. The pretty little blossoms are surrounded by a green calyx and surmount the narrow capsules, which are usually from an inch to two inches long.

\section{NORTHERN TWIN-FLOWER}

\section{Linna borealis. Honeysuckle Family}

Branches slender, trailing. Leaves: obscurely crenate, thick, sometimes wider than long. Flowers: two-flowered, nodding: peduncles slender, erect, two-bracted at the summit; calyx-tube five-lobed; corolla tubularcampanulate, five-lobed.

This lovely fragrant plant, called after the great Linneus, the Father of Botany, is a

"Monument of the Man of Flowers,"

who loved its exquisite pink bells above all else in Nature, and who sealed his preference by adopting it as his crest.

There is no more charming spot in the mountains than some sequestered nook or shady bank carpeted and adorned by the delicate trailing branches of the Northern Twin-flower, its glossy green leaves mingling with the moss, and its pale pink pairs of bells, veined and lined with rose colour, growing 


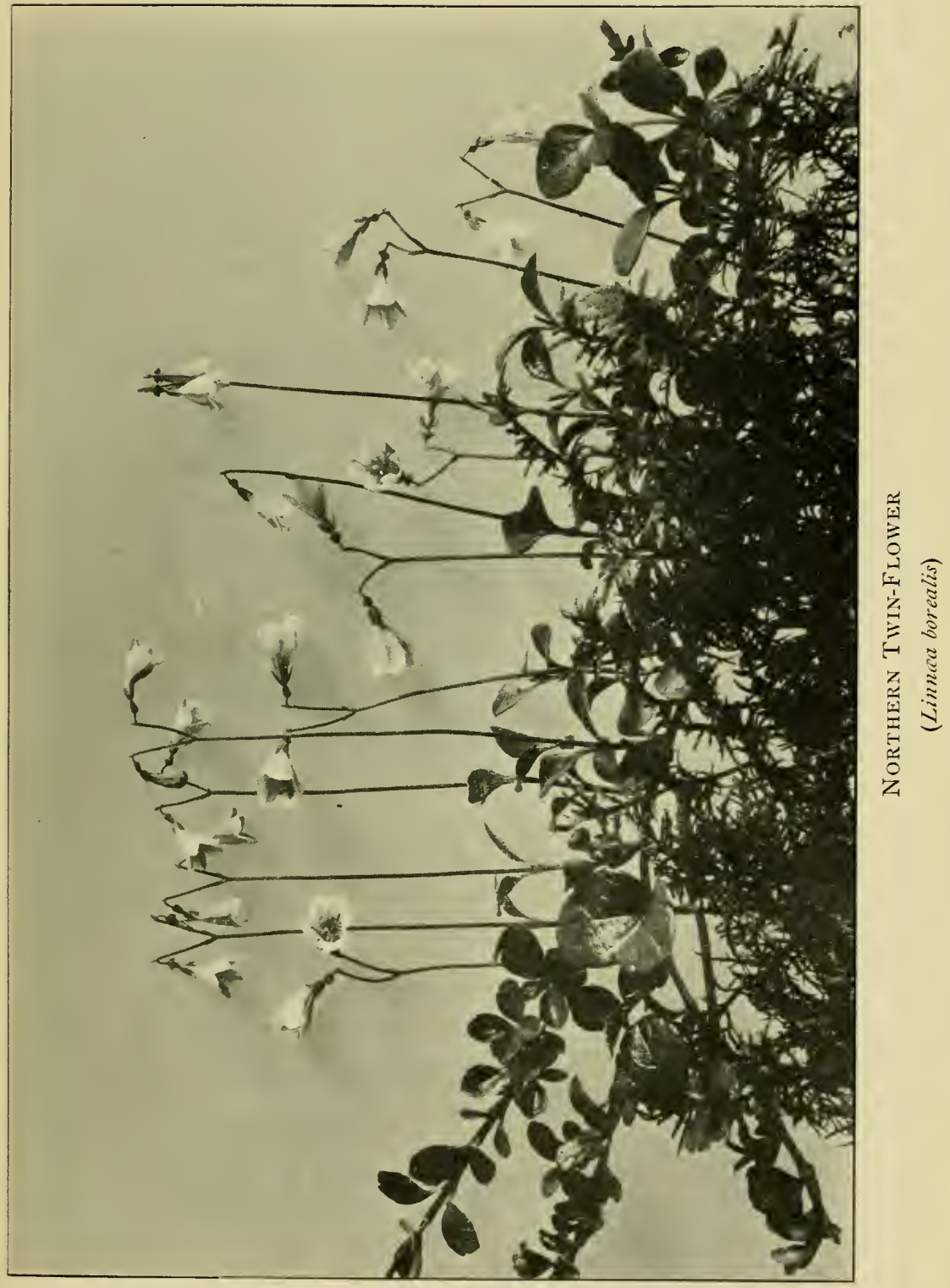



in lavish profusion and "gently to the passing breeze diffusing fragrance." The slender stalks of this vine stand up erect, and, forking near the summit, bear on either side twin-born pendent blossoms of rare loveliness.

Seeking the shade and moisture, this plant avoids exposed or sunny places, for

"Beneath dim aisles, in odorous beds,

The slight Linnæa hangs its twin-born heads,"

and reminds us as we gather its graceful perfumed bells that "sweetest of all things is wild-flower air."

It is widlely distributed throughout most northern countries, and is found even within the limits of the Arctic Circle.

\section{SMOOTH-LEAVED HONEYSUCKLE}

\section{Lonicera glancescens. Honeysuckle Family}

Twining, the branches glabrous. Leaves: chartaceous-margined, not ciliate, only the upper pair connate-perfoliate. Flowers: verticillate in a short, terminal, interrupted spike; corolla yellow changing to red, the tube strongly gibbous at the base, the two-lipped limb shorter than the tube; stamens and style exserted.

A climbing vine, with pairs of smooth leaves covered with a delicate bloom growing along its branches, only the upper ones joined together round the stem, which bears at its apex a cluster of red and gold flowers. These blossoms are trumpet-shaped, and the five stamens and style project beyond the corolla, which is vermilion outside and yellow within. The berry is soft and juicy. Sometimes this vine is called Woodbine, and Shakespeare in his exquisite romance of A Hidsummer-Night's Dream refers to this fact when he makes Queen Titania say to Bottom the Weaver, with whom the Fairy King Oberon has caused her by means of a love philter to fall in love :

"Sleep thou, and I will wind thee in my arms.

So doth the woodbine the sweet honeysuckle

Gently entwist." 
Milton in Lycidas speaks of "the well-attir'd woodbine," and truly, for no "gaclding vine "was ever graced with finer or more fragrant flowers.

Spenser calls it by the older name of Caprifole, or Goat-leaf, because, like the mountain goat, it climbs over almost inaccessible crags; the French and Italian names are also similar, being respectively Chicure-fcuillo and Caprifoglio.

\section{ROUGH FLEABANE}

Erigeron glabellus. Composite Family

Perennial by a woody root. Stems: simple or branched above, sometimes hirsute. Leaves: pubescent, entire, the basal ones spatulate; stemleaves oblong-lanceolate, obtuse or acute. Flowers: heads several or solitary, involucre hemispheric, hirsute; rays very narrow, about one hundred or more.

This charming Fleabane grows in dry soil and bears flowers of many hues, - pink, mauve, cream, and white. It has long narrow leaves, which, together with the stalks, are hairy.

\section{PINK EVERLASTING}

Antennaria parrifolia r'ar. rosea. Composite Family

Floccose-woolly, surculose, forming broad patches. Leaves: basal ones spatulate or obovate, white-canescent on both sides; stem-leaves linear, sessile. Flowers: heads in a terminal capitate or corymbose cluster.

The Pink Everlasting is so conspicuous by reason of its rosy crackling flowers, with their white silky centres and white woolly stems and leares, that it requires little definite description for identification. It has a tuft of procumbent foliage at the base, and all the way up the stem there cling many tiny narrow leaves. Growing from two to twelve inches high, this plant will be found in the same localities as the white species. 


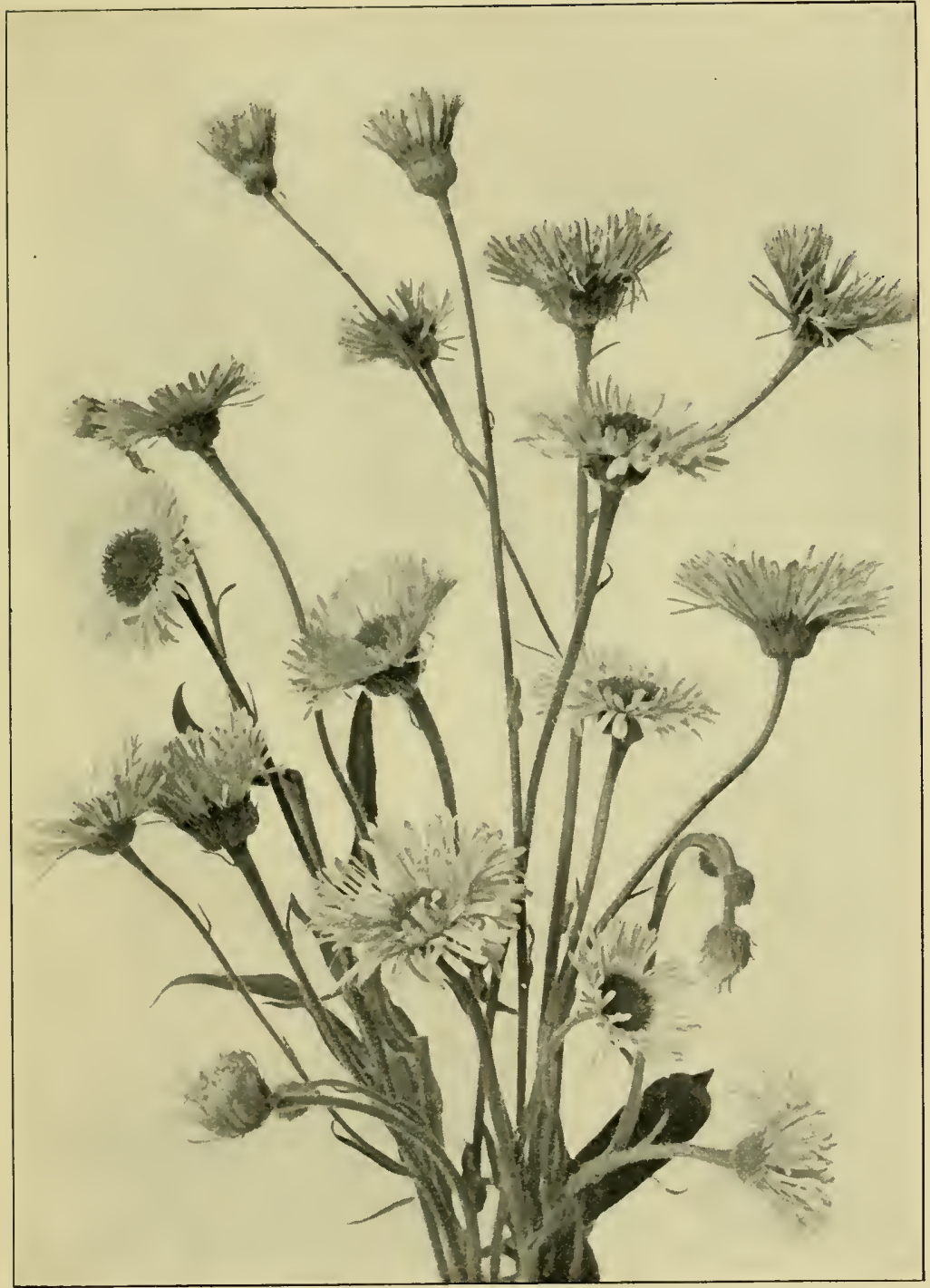

ROUgH FLEABANE

(Erigeron glabellus) 



\section{DWARF BILBERRY}

Vaccinium caspitosum. Huckleberry Family

Stems: much branched. Leaves: obovate to cuneate-oblong, obtuse, thickly serrulate, reticulate-veiny. Flowers: corolla ovate. Fruit: large, sweet, blue berry, with a bloom.

The Dwarf Bilberry is really a tiny shrub, but is placed in this Section, as it is so small that few people would think of looking for it in the Flowering Shrubs Section.

It grows only from three to seven inches high, and has many little fine branches thickly covered with leaves, which are bright green on both sicles. These stem-branches bear numerous tiny, bell-shaped, pinkish or white flowers, with the calyx five-toothed and about ten stamens. These in time turn to sweet blue berries, covered with a rich bloom, and so large as to be out of all proportion to the plant.

$I$. Myrtillus, or Alpine Bilberry, closely resembles the preceding species, but grows slightly taller and has a very prominent mid-rib in its leaves, which latter are extremely shiny. It also has pale pink or white bells. The berry is black and nodding.

\section{MOUNTAIN CRANBERRY}

\section{Vaccinium Vitis-Idaa. Huckleberry Family}

Branches tufted from creeping stems. Leaves: crowded, oval, emarginate, shining above, pale bristly and dark-dotted beneath. Flowers: crowded in a short terminal secund and nodding bracteate raceme.

The most remarkable feature of this low, creeping, evergreen shrub is that it has numerous black bristly dots beneath the leaves. The clusters of tiny, waxen, pink bells grow on erect branches, which spring from the creeping stems and attain to a height of about eight inches. The berries are dark red and very acid 
Though in reality a shrub, - which means that it is a woody plant whose stems do not die down to the ground in the winter, - the little Mountain Cramberry is placed in this Section, where most readers will look for it.

\section{SMALL CRANBERRY}

\section{Oxycoccus anlgaris. Huckleberry Family}

Branches ascending. Stems: very slender, creeping, rooting at the nodes. Leaves: thick, evergreen, ovate, entire, the margins revolute. Flowers: umbellate, nodding on erect filiform pedicels; corolla pink. Fruit : berry globose, acid.

A creeping shrub, with alternate leaves that are dark green above and white beneath. It is very delicately formed and resembles a slender trailing vine far more than a shrub, which latter word we are accustomed by common usage to apply only to tall, stout, or bushy plants. The four or five tiny, narrow, pink divisions of the corolla are spread wide open and reveal the anthers converging into a cone, which is extremely prominent when the flower is expanded. The fruit is a round, red, juicy, many-seeded berry. This Cranberry grows chiefly in marshy places and swamps, also along the margins of lakes and pools.

\section{RED BEARBERRY}

\section{Arctostaphylos Uita-ursi. Heath Family}

Diffusely much branched, and rooting at the nodes. Leaves: oblongspatulate, obtuse, tapering into a short petiole. Flowers: few, in short racemes; corolla ovoid, constricted at the throat. Fruit: globose, drupe red, ghabrous, containing five coalescent nutlets.

Another trailing shrub which is exceedingly handsome; it srows in depressed patches several feet in cliameter, from a single main root. It is usually found creeping over dry gravelly places, and covering the rocks with its bright little evergreen leaves. In the attumn these leaves turn bronze, and lovely scarlet, dry, berry-like fruits gem the sprealing branches. 
PLATE XLVII

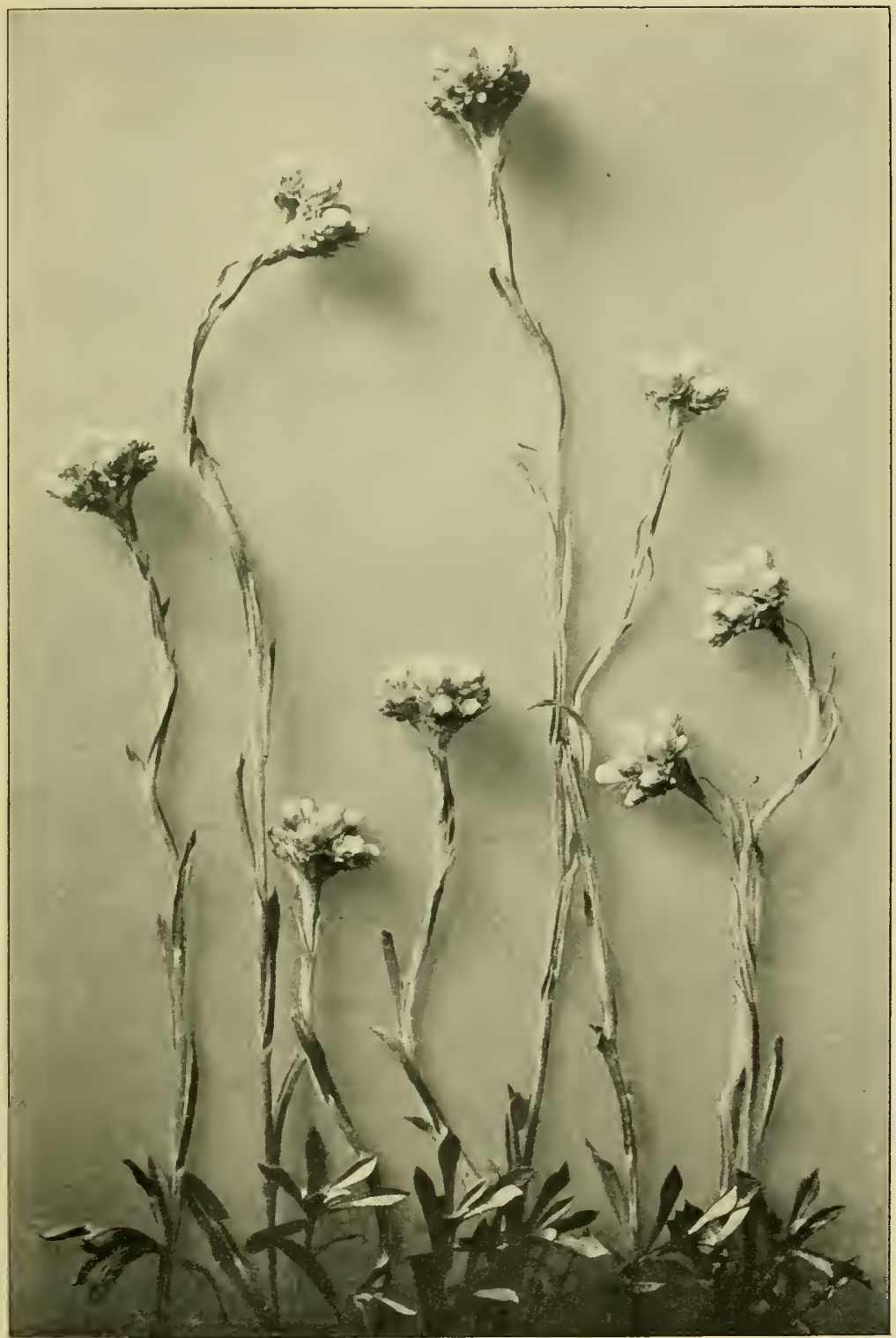

Pink Ererlasting

(Antennaria parvifolia var. rosea) 

White flushed with rose colour are these tiny rounded flowers, constricted at the throat, and giving forth a faint sweet odour.

"Oh! to be friends with the lichens, the low, creeping vines and the mosses,

There close to lie;

Gazing aloft at each pine-plume that airily, playfully tosses

"Neath the blue sky."

Doubtless the name Bearberry is derived from the fact that Bruin is very fond of the fruit of the Arctostaphylos, though with small game birds, and especially grouse, it is also a favourite article of food. The Indians call it Kinnikinic and prize it for its astringent properties, using it as a medicine and also in the "curing" of animal skins.

A. alpina, or Alpine Bearberry, is a very tiny species, from two to four inches long, and is found growing on mountain summits as high as 7000 feet. It is usually prostrate, with thin, conspicuously veined leaves, a few pale pink or white flowers, and bright red juicy berries. This is also a shrub and in spite of its small size has shreddy bark.

\section{RED FALSE HEATHER}

\section{Bryanthus cmpetriformis. Heath Family}

Densely much branched from the base. Leaves: strongly revolute, thickened and rough margins. Flowers: umbellate, subtended by foliaceous and rigid bracts ; corolla deep rose colour, campanulate, five-lobed.

The False Heathers - there are no true Heathers indigenous to this continent - are also low branching shrubs, but are placed in this Section for the same reason as are the small Vacciniums and the Arctostaphylos, namely, because it is here that the traveller will expect to find them, deeming them ordinary flowers and not flowering shrubs.

The Bryanthus cmpetriformis grows abundantly in the mountains, and at very high altitudes. It is a wonderful sight 
to see acre upon acre covered with its beautiful bells, until the slopes of the hills and the alpine meadows seem to be literally clothed with a glorious robe of rose-red Heather, whose border is embroidered with the White False Heather and White Heath, the blue Speedwell and the yellow Arnica.

Many a traveller knows how true are the lines:

"When summer comes, the heather bell Shall tempt thy feet to rove";

and many a man has echoed in his heart:

"Here's to the heath, the hill, and the heather, The bonnet, the plaidie, the kilt, and the feather;

Here's to the heroes that Scotland can boast, May their names never die - that 's a Highlandman's toast!"

Truly a love for the Heath and the Heather is common to all nations, and is the especial trait of all mountain climbers.

B. intermedius, or Pink False Heather, is a much rarer plant and is found in comparatively few localities. I first reported it from the Selkirk Mountains in I90 I, though it had previously been reported from the Rockies by Macoun, Drummond, and Dawson.

It is easily known to travellers by means of its lovely pale pink bells. The foliage is precisely similar to that of B.cmpetriformis, but the flower differs in a few very minor particulars.

\section{SWAMP LAUREL}

\section{Kalmia glauca. Heath Family}

Branches glabrous, ascending. Leaves: opposite, nearly sessile, linearoblong, margins strongly revolute. Flowers: in simple terminal umbels; bracts large; sepals ovate, much imbricated, persistent.

Yet another little shrub placed in this Section. Growing usually about a foot high, though frequently only a few inches tall, it bears at the ends of its slender branches large clusters of bright rose-red or magenta flowers, which have a five-lobed 


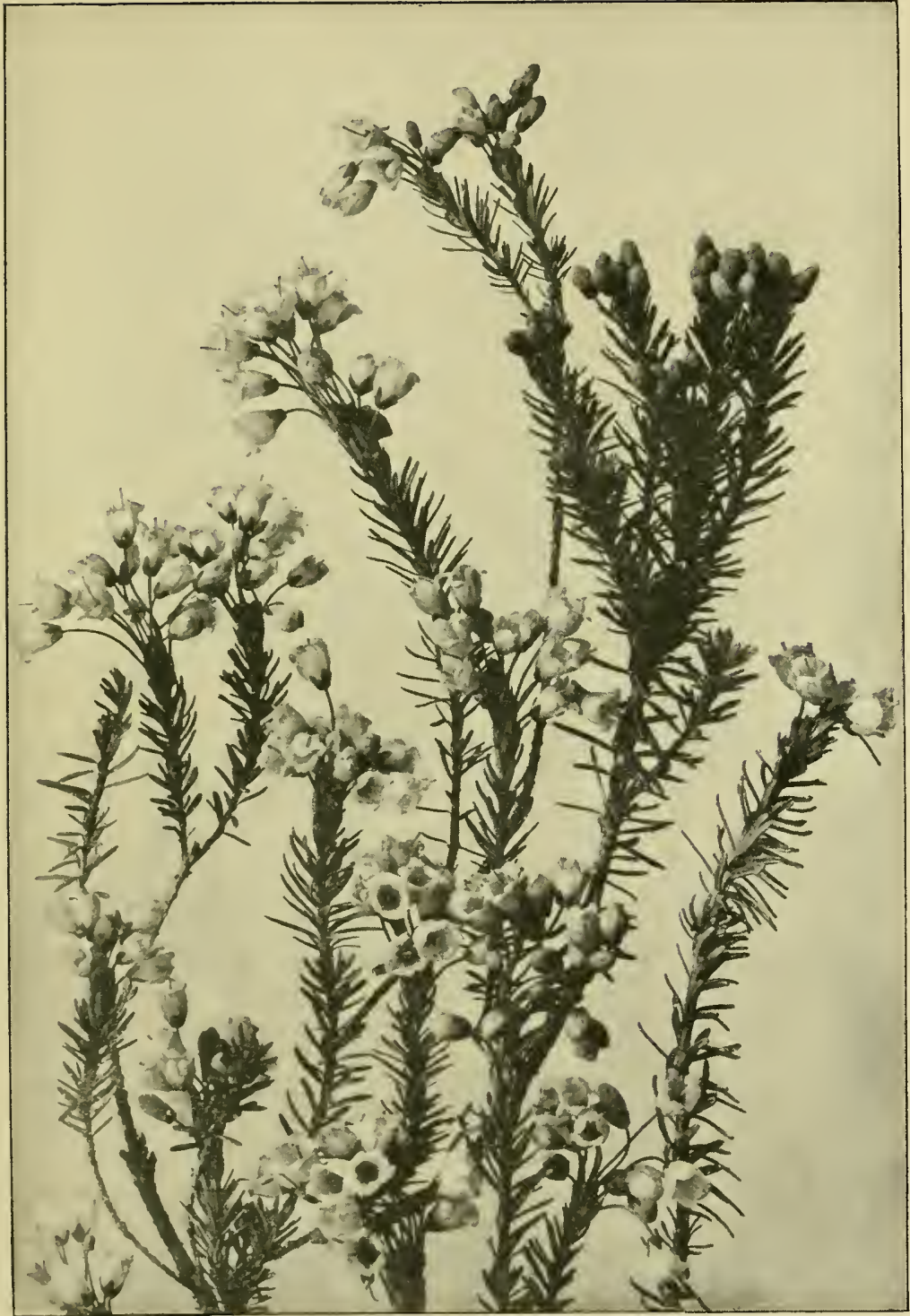

RED FALSE HEATHER

(Bryanthus empetriformis) 

corolla and ten stamens, whose filaments are slightly curved, by reason of the red-brown anthers being caught in the ten pouches which are placed below the limbs, or expanded lobes of the corolla. If you flip the outer edge of the Swamp Laurel gently with your finger, you will see the little stamens spring upright, sending forth a shower of pollen from their anthers in the process. The heart of the flower is usually pale green. Its evergreen foliage is dark green above and covered with a white bloom beneath, which latter characteristic gives it the distinguishing title of glauca.

The Swamp Laurel, as its common name implies, grows in marshy ground.

\section{RED WINTERGREEN}

\section{Pyrola asarifolia. Heath Family}

Stems: scape six-to-twelve flowered. Leaves: coriaceous, shining above, reniform, wider than long, crenulate. Flowers: racemose, nodding; petals five, obtuse; calyx five-parted, persistent, the lobes triangularlanceolate; stamens declined; style declined and exserted.

The tall red stalk of this Wintergreen, with its numerous nodding rosy blossoms, is exceedingly attractive, especially as it grows in the deep moist woods, where few flowers flourish owing to the absence of all sunlight. Very fragrant also is this quaint plant, to which the name of Wintergreen has been given on account of its evergreen foliage. The long outcurved style, which protrudes far beyond the floral cup, is green, and has a dull red stigma, while the ten stamens are tipped by dark, slightly beaked anther-sacs. The calyx is entirely of a deep red hue, and the petals are bright coloured at the outer edges, shading into palest pink in the centre. The leaves grow in a cluster at the base and are thick, tough, and glossy. A few narrow little bracts cling to the flower-stalks.

Sheltered from the wind and the sun, half hidden by mosses and tangled undergrowth, but always preferring a damp spot 
to a dry one, the Red Wintergreen grows in close companionship with the lovely One-flowered Wintergreen, the Longbracted Orchis, and the Butterwort; and if you know the "Secret paths that thread the forest land,"

you may find them in profusion, mingled at your feet by happy chances, - a gay holiday throng.

\section{BIRD'S-EYE PRIMROSE}

\section{Primula farinosa. P'rimrose Family}

Leaves: oblong, obluse at the apex, narrowed at the base, tapering into petioles, the margins crenulate. Flowers: umbellate; bracts of the involucre acute; calyx-lobes acute, often mealy; corolla salver-form, fivecleft; stamens five included filaments; anthers very short, oblong, obtuse.

A tall species of Primrose, with pink, lilac, or very occasionally white flowers, which grow in a cluster at the top of the long stalks and are salver-shaped; that is to say, the divisions of the corolla spread out flat at the top of the tube and disclose a yellow eye with five stamens forming a dark "pupil" in the centre of it. Hence the name of Bird's-eye. The leaves are long-shaped, being usually mealy white beneath, as denoted in the term farinosa, and all grow in a tuft at the base of the plant, surrounding the long bare flower-stalk, on the top of which a few small bracts will be found just below the blossoms.

$P$. Mistassinica, or Dwarf Canadian Primrose, is similar to the preceding species, but much smaller, growing only to an average height of four inches, whereas $I$ ? farinosa is usually about ten inches tall. The tiny leares are all set in a tuft close to the ground, and are rarely mealy underneath; while the flowers are pale mauvish-pink in colour. Both these l'rimroses grow in very wet places. The generic name, I'rimuler, refers to their carly season of blossoming, for, as the poet says :

"Primroses, the spring may love them,

summer knows but little of them." 


\section{SHOOTING STAR}

Dodecatheon pauciflorum. Primrose Family

Stems: scape glabrous. Leaves: lanceolate, entire. Flowers: segments of the corolla rich purple-pink, the undivided part yellow, with a scalloped ring of deep purple midway between the base of the segments and the stamen-tube; stamen-tube yellow; anthers purple.

From two to eight of these quaint purple-pink flowers, each one on its own individual tiny stem, grow at the ends of the stout main stalks of the plant. Several of these stalks grow up from every root. With their reflexed petals, resembling those of the Cyclamen (which also belongs to the Primrose Family), and their queer little pointed noses, the Shooting Stars are rather remarkable-looking flowers. They remind one of some bright-winged butterfly poised on the apex of a scape. The leaves all grow in a cluster at the foot of the plant and are long-shaped and tapering towards the base. Very occasionally the flowers are white. The scientific name is derived from the Greek dodcka, "twelve," and theos, "god," thus signifying "twelve gods." I ts application is not very clear, though Linnæus imagined he saw in its umbels of bright crowned flowers a little congress of divinities, and hence named it for an Olympian gathering of the gods.

\section{RED MONKEY-FLOWER}

\section{Mimulus Lewisii. Figwort Family}

Stems: numerous, pubescent, viscid. Leaves: oblong-ovate to lanceolate, denticulate, acute. Flowers: peduncles longer than the leaves; calyx long, campanulate, its triangular teeth very acute; corolla with broad throat and bilabiate limb, lobes of the upper lip obcordate, of the lower lip obovate.

A tall handsome plant, with ample foliage. The leaves are sharply toothed at the edges and very pointed at the apex; they grow in pairs, clasping the stem, and from their axils 
spring the slencler flower-stalks bearing brilliant magenta blossoms. Each of these blossoms has a long green calyx, from out of which comes the richly coloured tube, that spreads open into two lips, the upper one being reflexed and two-lobed and the lower one spreading and three-lobed. The throat has two yellow patches inside and is covered with white hairs; indeed, the whole plant is extremely hairy and sticky, and has a sweet sickly smell.

The favourite haunt of the Red Monkey-flower is some damp hollow, either in marshy ground or on the banks of an alpine stream. Though never actually growing in the water, it may frequently be found flourishing luxuriantly on those little islands so common in the midst of mountain rivers, where, sheltered by other large moisture-loving herbs, it attains a height of from one to two feet.

Mimulus is the climinutive of the Latin mimus, meaning "a mimic actor," and alludes to the laughing face of the flower, which appears to shoot out its ripe red lips in mockery at the traveller as he passes by, opening its mouth in a droll grimace that displays its yellow throat. Hence also the common name Monkey-flower, given in allusion to the ape-like pertness of the plant's appearance. Thus man has set a "cap and bells" upon the Mimulus and appointed it buffoon to the Court of Nature.

\section{RED INDIAN PAINT-BRUSH}

\section{Castilleia septentrionalis. Figwort Family}

Stems: simple. Leaves: alternate sessile, undulate or crenate, the lower ones linear, the upper ones lanceolate, acuminate; bracts oblong, oval, obtuse, as long as the sessile flowers. Flowers: in dense, terminal, leafly-bracted spikes: corolla tubular, very irregular, not longer than the calyx, its limb bilabiate; calyx tubular, cleft on both sides to about the middle, usually again two-cleft.

This flower, though actually of a pale greenish-yellow colour, is almost entirely enfolded in a long, tubular, greenish calyx, so 
PLATE XLIX

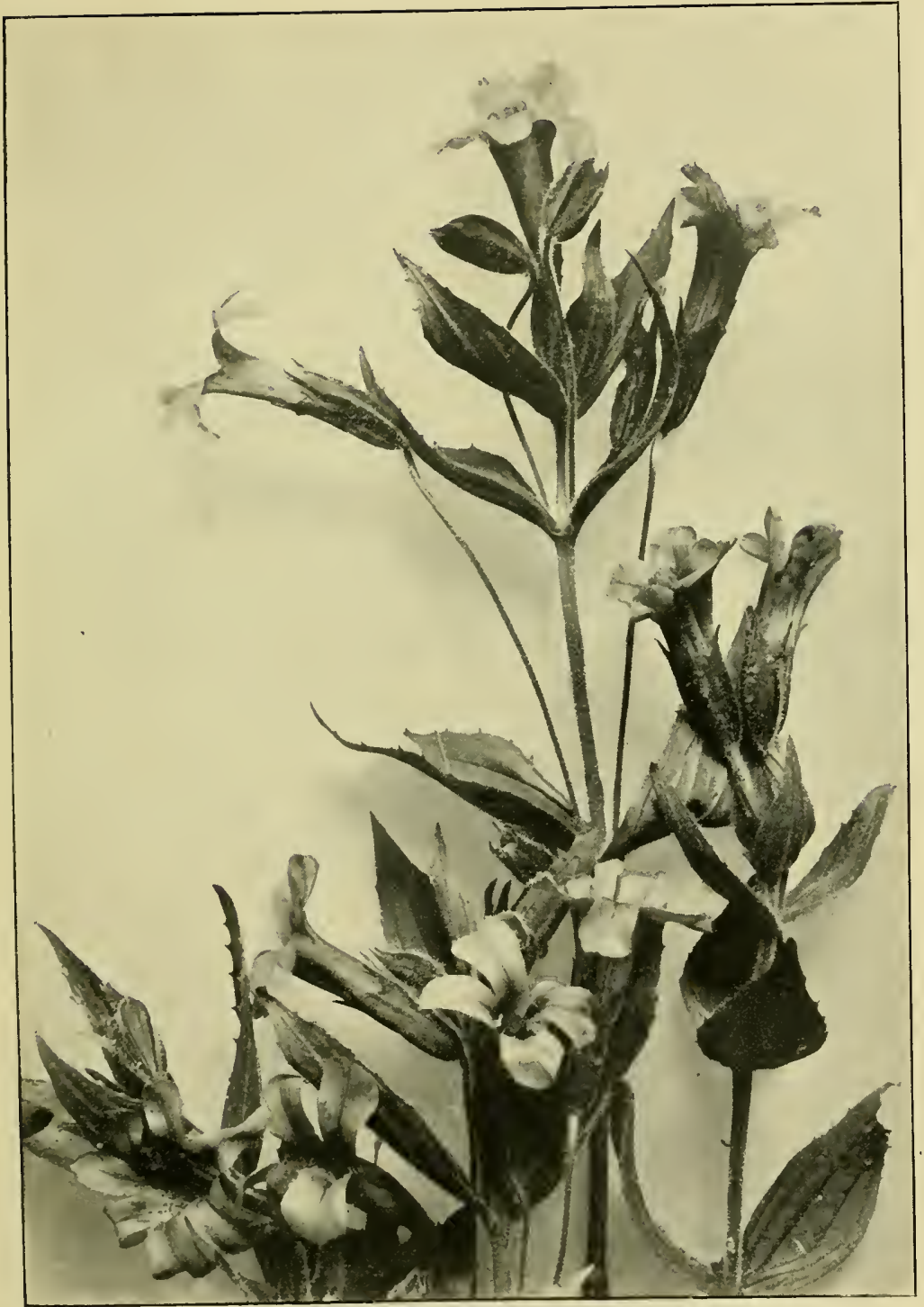

Red Monkey-Flower

(Mimulus Lewisii) 
that it is chiefly conspicuous by reason of its large gorgeously coloured bracts of pink, rose, scarlet, crimson, or orange (and sometimes white), and therefore I have placed it in the Pink to Red Section, for it is here that most people will look for it, as only botanists are ever likely to guess that it is not in reality a gaudy flower.

The Red Indian Paint-brush is the only alpine wild flower that really rivals the scarlet geranium of our cultivated gardens, and no grander sight may be seen by travellers than where from "tree-line," close to the edge of the eternal snows that enfold the towering mountain tops, down into the deep green heart of the valleys, the slopes and steeps are clothed with a marvellous mantle of vermilion and golden Castilleias. As the sunlight flames across these royal-robed hills every blossom blooms and burns with effulgent glory, until

" Earth 's crammed with Heaven, And every common bush afire with God."

No words can describe the brilliant beauty of such a scene, far from uncommon at the higher altitules, where many species of Castilleia thrive abundantly, and you may walk for miles across meadows and banks whereon the Paint-brushes and Painted-cups (or Flame-flowers, as they are sometimes called) run riot in magnificent profusion. Every colour, every shade from coral pink to cardinal, from canary tint to tangerine, is growing and blowing on either hand, with here and there a single snowy spike to emphasize the splendid conflagration of colour.

It is wonderful to note that all this carmine and gold is not lavished on the corolla of the flower at all, but only on the bracts, which are set below each insignificant blossom, from whose cleft tube the long pistil protrudes. The plant grows from six inches to two feet high and the leaves have wavy or scalloped margins.

The Castilleias are parasitic on the roots of other plants: that is to say, they sometimes fasten their roots upon those 
of their neighbours and thus prey upon juices already partially assimilated. They have not, however, as yet become harclened thieves; if they had, they would have lost their leaves and green colouring matter (chlorophyll), for every plant that turns pirate is punished by Nature, and branded for all the world to see, by being sractually eleprived of its foliage and its honest hue. But the Castillaia is only gruilty of petty larceny, being but a partial parasite, and so far it is the botanist, and not Nature, who has denounced its backsliding.

C. pallida, or White Indian I'aint-brush, much resembles the preceling species, but its flowers and bracts are always greenish-white, cream colour, or palest ycllow. It is a small short plant, with slender stems and tiny narrow leaves, and it only grows at very high altitudes.

Though this species properly belongs in the White to Green Section, it is placed here for greater convenience.

\section{BRIGHT PAINTED-CUP}

\section{Castillcid miniuta. Figwort Family}

Stems: numerous and tufted on a short rootstock, mostly simple and strict. Leaves: lanccolate or ovate-lanceolate, acute, entire. Flowers: spikes short and dense; corolla long; galea exserted, longer than the tube, the short lower lip protuberant and callous with short, ovate, involute teeth.

The leaves of the Bright Painted-cup are entire; that is to say; their margins form an unbroken line and are not wavy, nor have they uncven rounded teeth like those of $C$. siptentrionalis. The corolla is very pale in colour, but the bracts are nearly always red or magenta.

Thoreau speaks thus of the prairic species:

"The Painted-cup is in its prime, It reddens the mcadow, - Paintedcup meadow. It is a splendicl show of brilliant scarlet, the colour of the Cardinal Flower, and surpassing it in mass and profusion. I do not like the name. It does not remind me of a cup, rather of a flame when it first appears. It might be called Flame-flower, or Scarlet-tip. Here is a large meadow full of it, and yet very few in the town have 
PLATE L

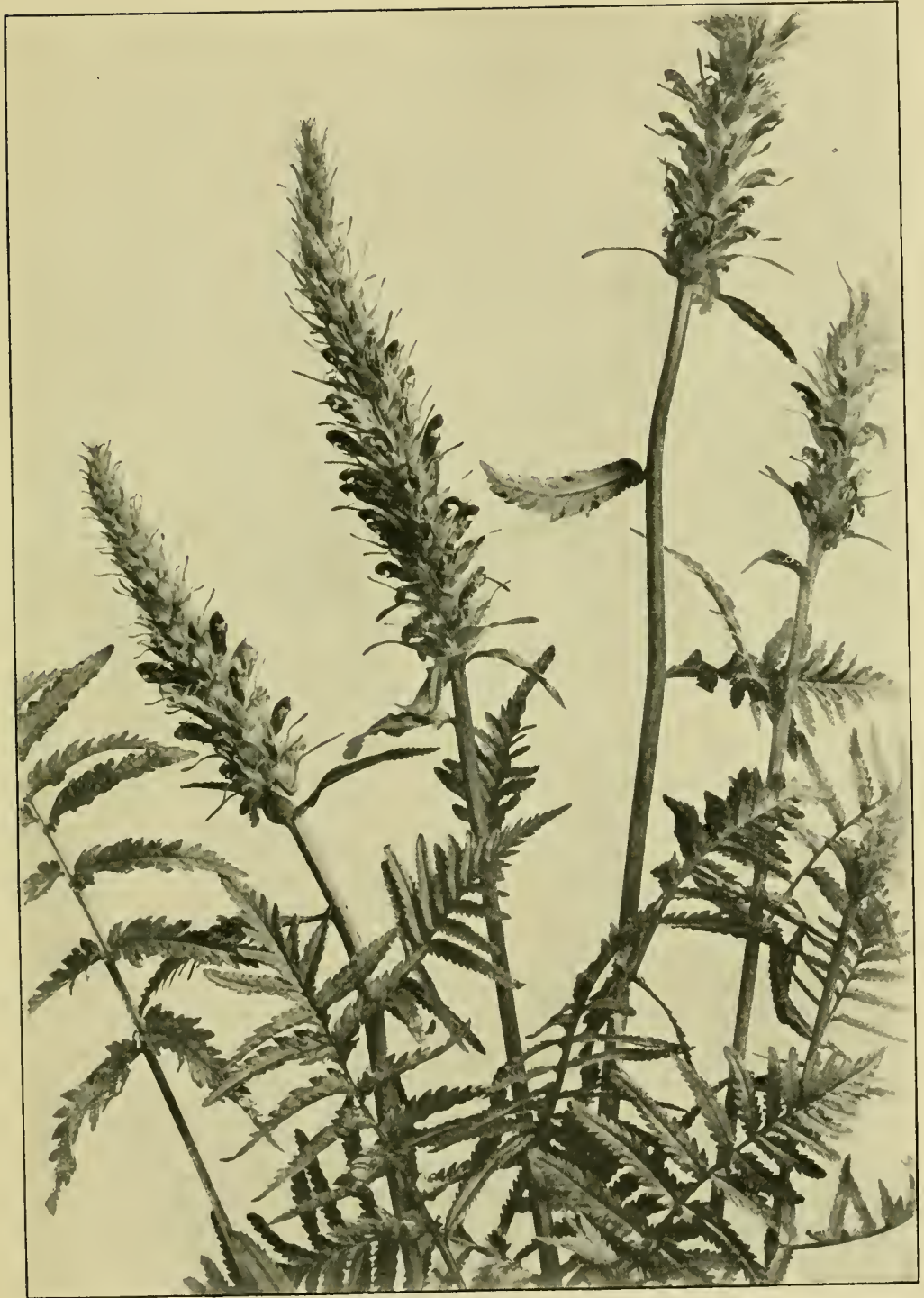

WOOD BETONY

(P'edicularis bracteosa) 

ever seen it. It is startling to see a leaf thus brilliantly painted, as if its tip were dipped into some scarlet tincture surpassing most flowers in intensity of colour."

These words are equally applicable to the mountain Castilliass. Truly the glorious flower-spikes of the Paint-brushes and Painted-cups are like tongues of flame that run burning through the herbage of the hillsicles.

\section{"Scarlet tufts}

Are glowing in the green like flakes of fire."

And when we see them in their royal radiance we remember how the ancients once worshipped the God of Fire - and understand.

C. Bradburii, or Bradbury's Painted-cup, may be recognized by its leaves, which are large and cleft above the middle into three or five unequal lobes, the centre one being oblong and rounded at the apex, and the lateral ones narrower.

"Flowers that with one scarlet gleam

Cover a hundred leagues, and seem

To set the hills on fire."

\section{LONG-BEAKED PEDICULARIS}

\section{Pedicularis Groulandica. Figwort Family}

Stems: simple, erect. Leaves: alternate, lanceolate in outline, acute, pinnately parted into lanceolate incised segments, the lower petioled, the upper sessile. Flowers: spike very deise, long; calyx five-toothed; corolla the galea produced into a filiform beak.

This Pidicularis has slender, rather brittle, red stalks, which are clothed with many small, fern-like, reddish leaves, and a group of tall fringed foliage grows up about it from the ground. It is a tall plant, often attaining a height of eighteen inches, and its terminal spikes are long and densely flowered with tiny dull red blossoms, which have a toothed calyx that is nearly as long as the tooth of the corolla. The corolla is twolipped, the upper lip, or galea, being concave and having a long thread-like beak, while the lower one is three-lobed. 


\section{WOOD BETONY}

\section{Pedicularis bracteosa. Figwort Family}

Stems: stout, high, erect, simple. Leaves: linear in outline, the radical ones petioled, pinnate, the oblong leaflets pinnately parted, the segments incisely dentate, cauline broader in outline; bracts orate, shorter than the flowers. Flowers: spike cylindrical, very dense; calyx sparsely pillose; corolla ochroleucous, the tube equalling the calyx; galea longer and larger than the lower lip, its cucullate summit slightly produced at the entire edentulate orifice, but not beaked.

A tall coarse plant, with handsome, green, fern-like foliage, but clumsy uninteresting flowers. On the top of the stout reddish stems grow large, hairy, bracted spikes, with many small dull red flowers, which resemble a parrot's beak, with their raised hooded upper lips and small lower ones. These flowers are subtended by conspicuous bracts, hence the name bractcosa.

The Romans had a proverb, "Sell your coat and buy Betony," and another old saying was, "May you have more virtues than Betony." Antoninus Musa, physician to the Emperor Augustus, wrote in high praise of its powers, stating that it would cure forty-seven of the ills to which human flesh is heir.

Franzins, in his History of Brutes, allucles to its healing virtues for animals. He says of the stag, "When he is wounded with a clart, the only cure he hath is to eate some of the herbe called Betony, which helpeth both to draw out the dart and to heale the wound."

Sir WVilliam Hooker is our authority for saying that the common name is a corruption of bentonic, ben meaning "head," and ton "grood " or "tonic." 


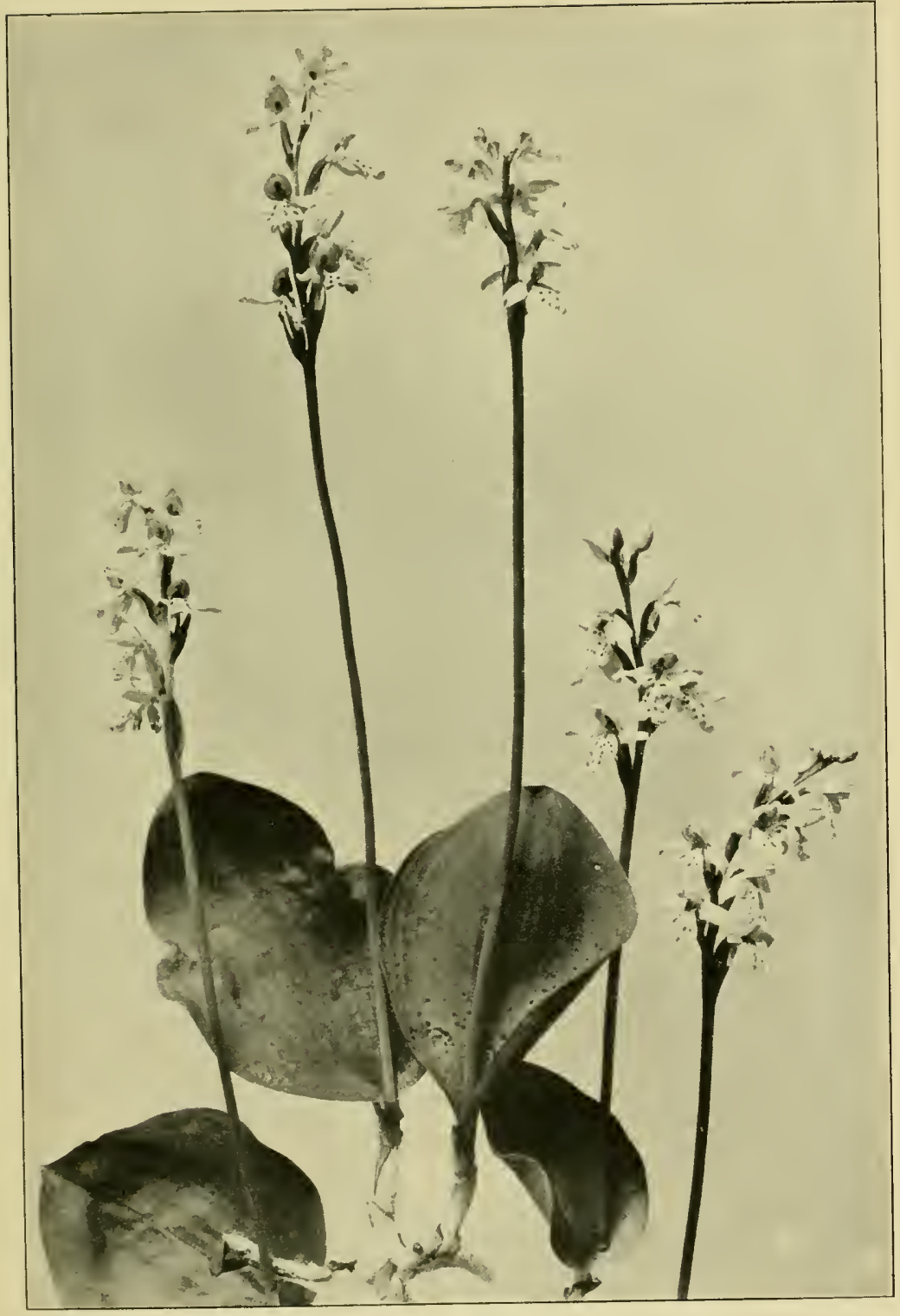

Fly-Spotted Orchis

(Orchis rotundifolia) 



\section{CALYPSO}

\section{Calypso borealis. Orchid Family}

Stems: with two or three membranaceous sheaths, and a linear bract at the summit. Leaves: leaf solitary, broadly ovate, petioled. Flowers: drooping, pedicelled: sepals and petals lanceolate, acuminate, long lip inflated, saccate, with two short spurs below the apex.

A solid bulb and coralloid roots, a single stem sheathed by two or three loose brownish-green scales and surmounted by a single narrow bract, a solitary broad leaf at the base, and a single lovely mauvish-pink orchid blooming at the summit, such is the Calypso.

The sepals and petals of this dainty flower are like fairy wings, its large sac, striped and mottled with deep rose colour and variegated with yellow spots, tufted by fine white hairs, resembling the body of some gay insect; thus the blossom appears to be poised lightly upon its stem like a beautiful butterfly ready to flutter away at our approach. This effect is heightened by the fact that it grows in the deep cool forests, where its exquisite fragrant flowers form the only spots of vivid colour and where it is sheltered by the vines and mosses that cluster together in those damp shady places that are the favourite haunts of this orchicl.

IVhen Mrs. Hemans wrote

"There's not a flower but shows some touch,

In freckle, freck, or stain,

Of His unrivalled pencil,"

she must have had in mind the marvellous painted slipper of the Calypso, for its delicate veinings in finely pencilled pattern are surely the wonderful work of the Great Master-hand.

The name Calypso denotes that the plant is dedicated to the ancient goddess of that name. 


\section{FLY-SPOTTED ORCHIS}

Orchis rotundifolia. Orchid Family

Stems: slender. Leaves: leaf solitary, orbicular to oval, with one or two sheathing scales below it. Flowers: spike two-to-ten flowered, subtended by small bracts; sepals lateral ones spreading; petals similar to the sepals; lip longer than the petals, three-lobed, the middle lobe larger, dilated, notched at the apex; spur slender, shorter than the lip.

A lovely pale pink orchis, with a single roundish leaf growing at the base and roots composed of fleshy fibres. The clusters of flowers are slightly fragrant. Each blossom has a large, protruding, flat lip of palest pink, spotted with rose or purple, and divided into three lobes, the centre one being notched. A wing-like sepal stands out on either side, and the small petals and sepals are all pink, the arched petal that is bent down orer the stamens being spotted with rose-purple like the lip. It is found in moist places and grows to full perfection where very wet ground combined with a full exposure to the sun is possible.

\section{PINK LADY'S SLIPPER}

\section{Cypripedium acaule. Orchid Family}

Stems: scape pubescent. Leaves: two large basal ones elliptic, thick, one small leaf on scape. Flowers: solitary; sepals lance-shaped, spreading, the two lateral ones united under the lip; lip very large inflated sac, pink with rose veins, the upper interior crested with long white hairs.

A rare treasure, so beautiful in hue, so very fragrant! Only a single chrooping flower grows at the top of each scape, havincr a large pink sac that is split open in front and merely folded close together, in which particular it differs from the yellow and the white species. A long narrow sepal spreads out on either side of the lip, and both the sepals and petals are greenish or purplish.

"Graceful and tall, the slender drooping stem,

With two broad leaves below,

Shapely the flower so lightly poised between,

And warm her rosy glow." 
PLATE LII

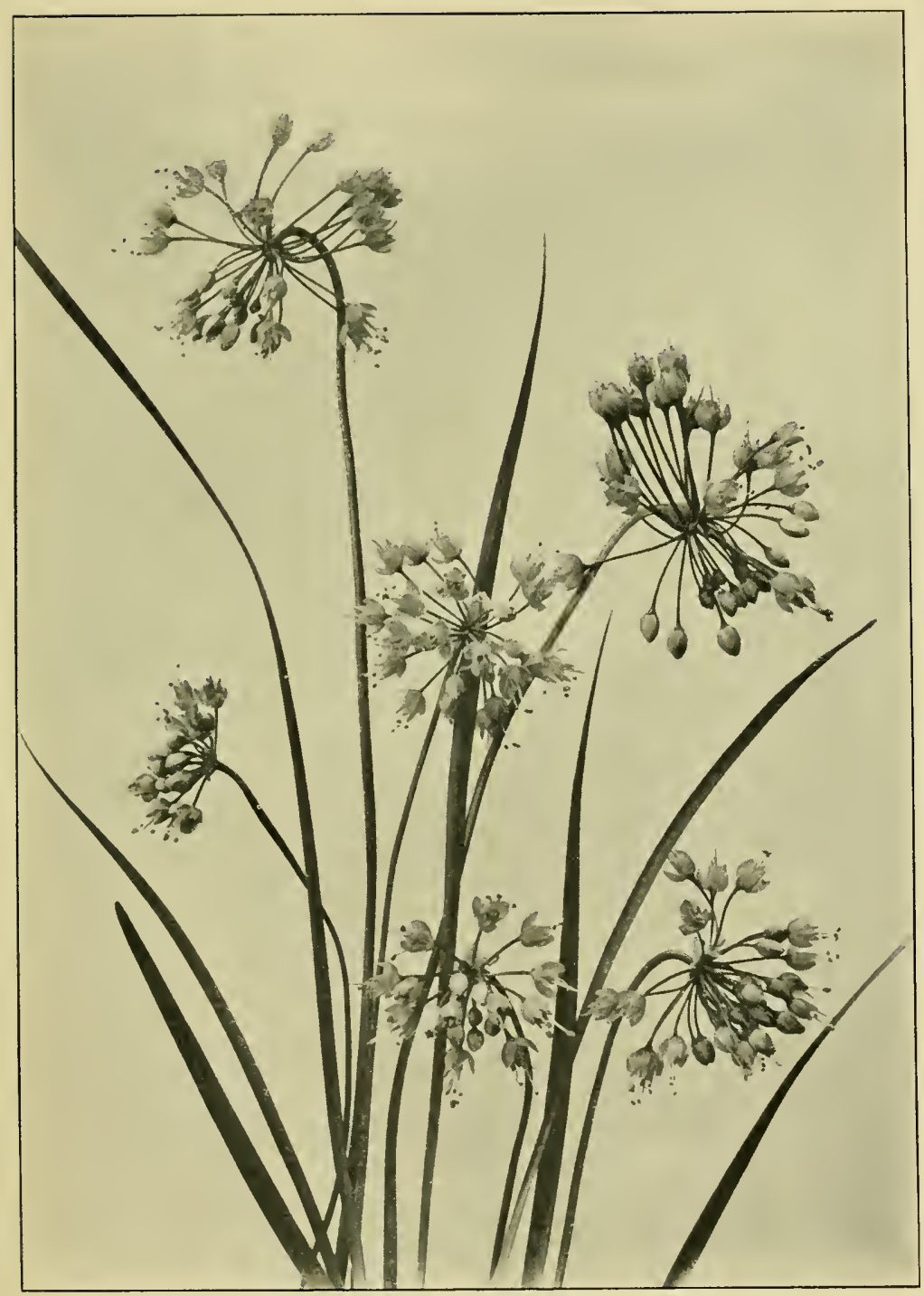

PINK GARLIC

(Allium recurvatum) 

This verse aptly clescribes the fragrant Pink Lady's Slipper, or Moccasin Flower, as it is often called, - a rare species which is absolutely unmistakable, if only by reason of its sweet odour and rich and lovely hue. The stamens are united in a declined column, carrying an anther on either side, and there is a long, triangular, dilated, sterile stamen arching over the summit of the broad three-lobed stigna.

The name Cypripedium comes from the Greek, and means Venus's sock or buskin. Truly this lovely pink slipper is fit to adorn the foot of the Queen of Beauty.

\section{PINK TWISTED-STALK}

Streptopus roseus. Lily Family

Stems: from a short stout rootstock covered with fibrous roots, simple or sparingly branched. Leaves: lanceolate to ovate, abruptly acuminate, sessile by a broad, rounded, clasping base, the margins finely ciliate. Flowers: peduncled, segments of the perianth lanceolate. the tips spreading. Fruit: a red oval berry.

This plant is a near relation of $S$. amplerifolius described in the White to Green Section. It differs from the foregoing, however, in several essential particulars. In the first place, it is a smaller plant, has dull purple-pink pendent bells, and is nearly always one-flowered. Then, too, the tiny pecluncles are not sharply twisted as in S. amplcxifolius, but bend downwards in a graceful curve. The rosy-hued bells are quite hidden beneath the leaves and may be seen only when the long stems are turned over. These bells are streaked outside and lined inside with deep rose colour.

There are two other species of Pink Twisted-stalk in the mountains, - one called S. curaipes, or Curved Twisted-stalk, and the other S. brevipes, or Short-stemmed Twisted-stalk, a very small plant which commonly grows far west. 


\section{PINK GARLIC}

\section{Allium recuratum. Lily Family}

Bulbs clustered on a short rootstock, narrowly ovoid, with a long neck. Stems: scape slender. Leaves: linear, channelled, or nearly flat. Flowers: umbel many-flowered, nodding, subtended by two short deciduous bracts; perianth segments ovate, acute; stamens and style exserted.

These clusters of tiny pink flowers, which grow on long slender stalks that bend over abruptly at the top (hence the name recurvatum), are characteristically odorous, as may be readily understood, since allium is the Latin for "garlic." From ten to forty flowers form the umbel upon each stalk, and both the awl-shaped stamens and the style protrude far beyond the segments of the perianth.

The leaves are long and extremely narrow, in fact grasslike, being channelled or flat and terminating either in a blunt or a fine point. 


\title{
MOUNTAIN WILD FLOWERS
}

\author{
OF AMERICA
}

\author{
Section III
}

BLUE TO PURPLE FLOWERS 



\section{Section III \\ BLUE TO PURPLE FLOWERS}

Flowers that are bluc to purple, or occasionally so, but not described in this Section

PAge

Wild Heliotrope . . . . Faleriana sylzatica (White to Green Section) . . . 67

White Heliotrope . . . Valcriana sitchcnsis (White to Green Section) . . . 67

\section{WILD CLEMATIS}

Clematis Columbiana. Crowfoot Family

A trailing and partly climbing vine. Leaves: trifoliolate; leaflets thin, ovate, acute, more or less cordate, slightly toothed or entire: petioles slencler. Flowers: solitary; sepals thin and translucent, strongly veined, silky along the margins and the veins; petals spatulate; styles persistent, plumose throughout.

The large lovely flowers of the Wild Clematis are attractive by reason of their four or five big purple-blue sepals, for their petals are very small and inconspicuous, surrounding the numerous yellow stamens. When in fruit this plant is also interesting, as the fine feathery styles form silvery heads, the long plumes of which are delicately entwined.

Its slender leaf-stalks are the means by which the Clematis climbs and clings to bushes, trees, and rocks, festooning with graceful garlands everything that comes in its way and delighting the traveller's eye with its wide-spread, semi-transparent, prominently veined flowers. The leaves are formed of three small, deeply veined leaflets, which grow on slim, rather woody stems. 
This plant is a constant ornament to the alpine woods during the summer months, for when its true flowering season is past the pretty green foliage and large tufts of feathery seeds still render it an object of admiration.

\section{PASQUE FLOWER}

\section{Anemone Nuttalliana. Crowfoot Family}

Stems: erect, villous with long silky hairs. Leaves : ternately divided, the lateral divisions two-parted, the middle one stalked and three-parted, the segments deeply cleft into linear acute lobes. Flowers: developed before the leaves; sepals five to seven; petals none. Fruit: achenes compressed, pointed, ending in long feathery tails.

The most remarkable feature of this large purple Anemone is that it blossoms before its foliage is dereloped. Frequently you will find lovely specimens of these flowers in full bloom, standing up very straight on their thick downy stalks, while the leaves, which are finely dissected, are still folded up in soft silkiness about the base of the plant. The five to seven sepals are pale purple outside, but almost white inside, and are extremely soft and silky, while below them on the stalk grows a circle of very hairy leaflets. Inside the floral cup are numerous yellow stamens clustered close together round the green carpels.

As time passes the stalks elongate, the purple flowers fall off, and the seeds are formed. Then the heads present a lovely plumose appearance, for to each seed is attached a long silky tail, the whole forming a pretty feathery tuft. 
PLATE LIII

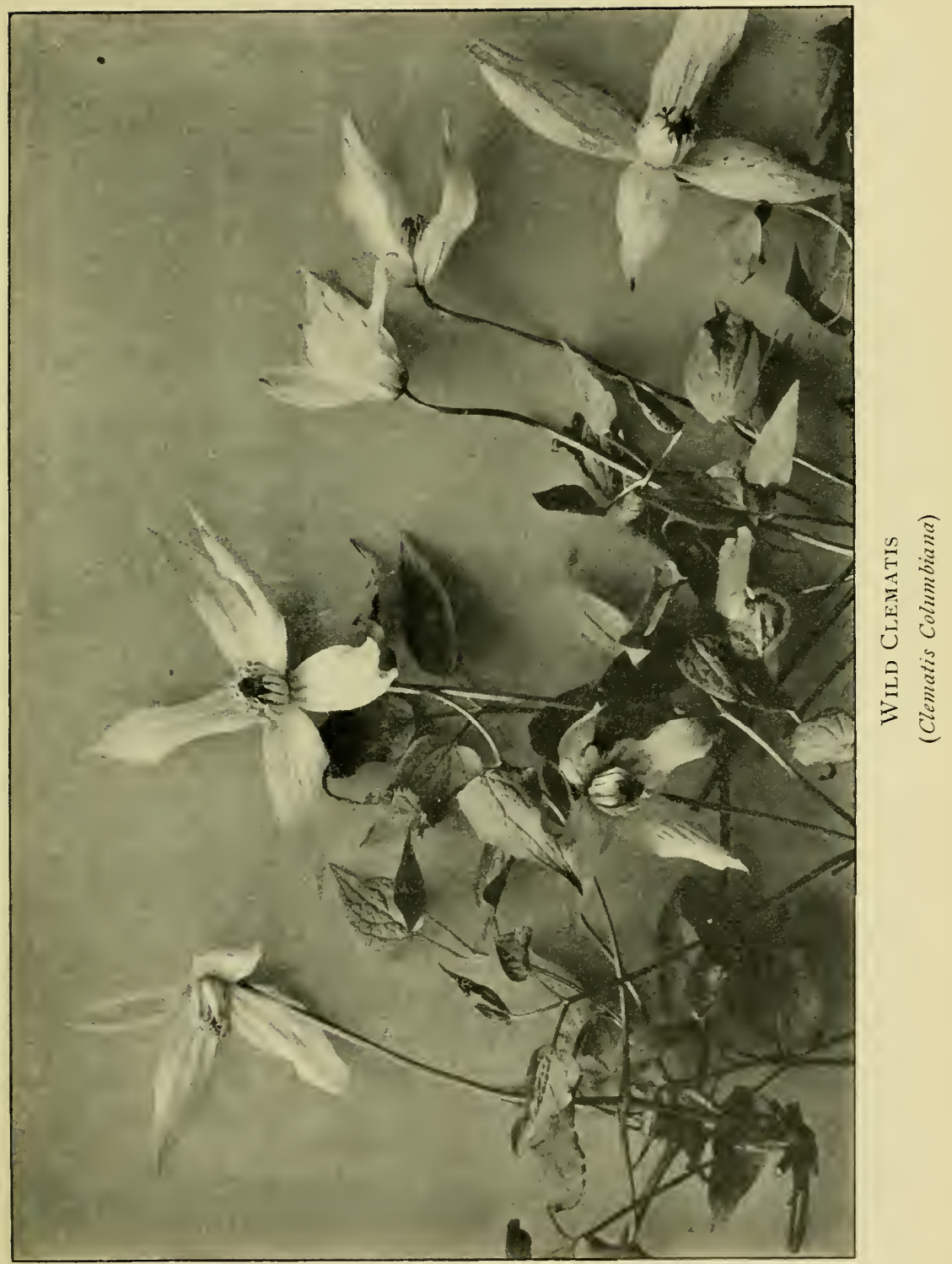



PLATE: LIV

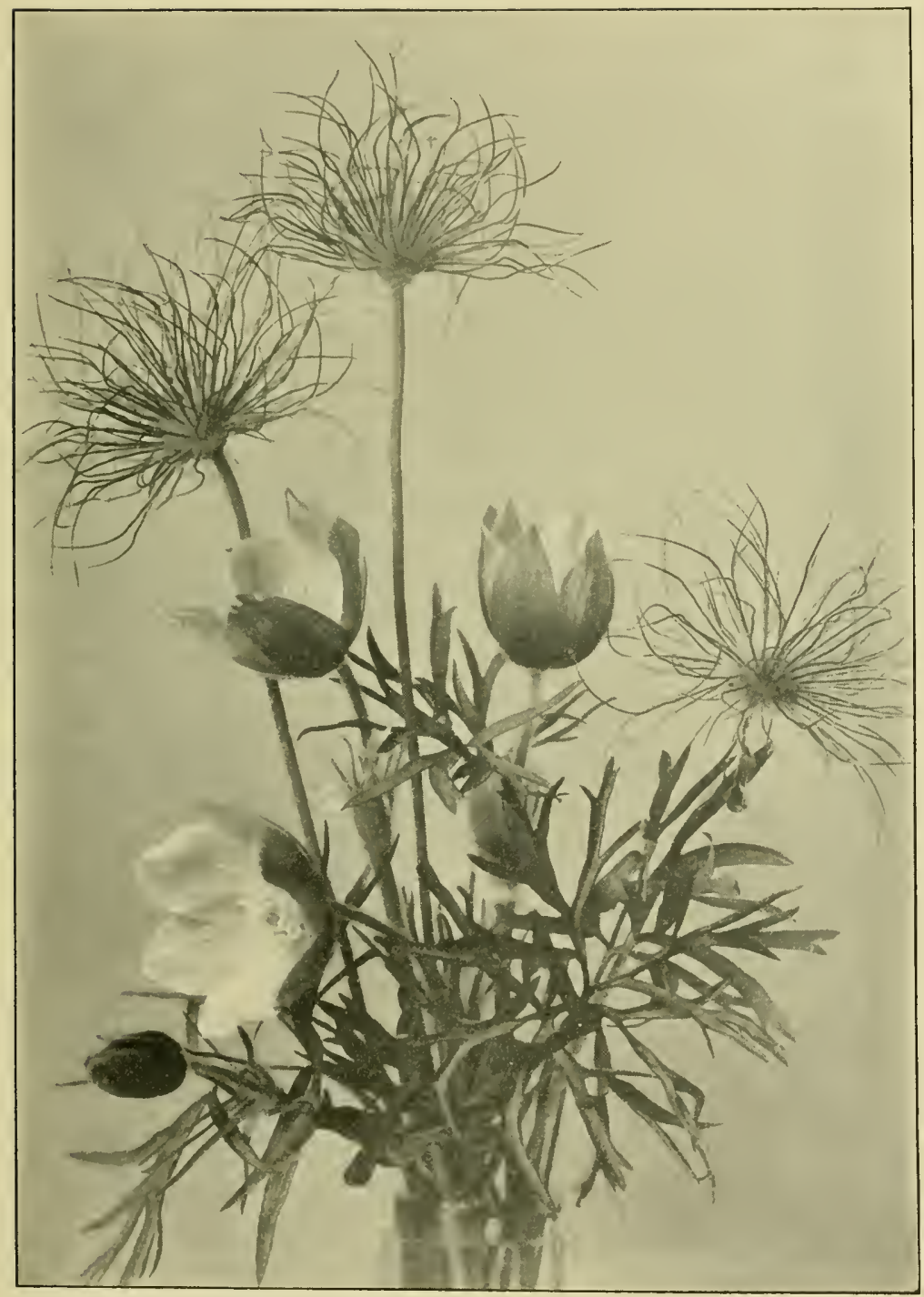

PASQUE FLOWER

(Anemone Nittulliana) 



\section{BLUE COLUMBINE}

Aquilegia brevistyla. Crowfoot Family

Stems: slender, erect, branching. Leaves : basal ones biternate, lobed and crenate; stem-leaves few, nearly sessile. Flowers: small, nodding, blue and white; spurs short.

The smallest of the mountain Columbines, it may easily be recognized by its mauvish-blue and creamy blossoms and its very short styles. It is a more compact and therefore less graceful flower than $A$. formosa or A. flavescens.

The Columbine was first introduced into England from the Virginia Colony in the reign of Charles I, when a young botanist sent it as a gift to the great Tradescant, gardener and herbalist to the King.

\section{MOUNTAIN LARKSPUR}

\section{Delphinium Brownii. Crowfoot Family}

Stems: tall from a fascicle of thick roots. Leaves: numerous, mostly orbicular in outline, five-to-seven parted, the lower into cuneate and the upper into narrower-cleft and laciniate divisions, petioled. Flowers: racemes many-flowered on short erect pedicels.

The tall Mountain Larkspur is a very handsome plant. It is nearly always a rich purple hue, but very occasionally it bears white or pinkish-mauve blossoms. Standing from one to six feet high, these Dclphiniums (so called from their fancied resemblance to a dolphin) may be found in immense quantities in the high alpine meadows, their long flower racemes towering up above a mass of deeply cleft dark green foliage. Each flower grows on a tiny upright stalk attached to the main stem, and has four small whitish petals, the upper pair smooth and developed backwards, and enclosed in the spur of the calyx, and the two lower ones deeply notehed and very hairy. The sepals are five in number and of a lovely intense blue colour; the top one is prolonged at the back into a hollow spur, and the others are plain. 
This plant is also called Monkshood, the reason wherefor may readily be seen.

D. Columbianm, or Blue Larkspur, is a smaller species growing only from six to eighteen inches high and having few leaves and fewer flowers on its hairy stems. Though usually

"Ilue as the hearen it gazes at,"

this Larkspur has sometimes white blossoms marked with purple veins.

\section{EARLY BLUE VIOLET}

Viola cognata. Violet Family

Acaulescent. Rootstocks short and thick. Leaves: long-petioled, cordate, with a broad sinus, the early ones reniform, the later ones acute or acuminate, crenately toothed. Flowers: large; petals villous at base; spur saccate.

This large Early Violet is really of a true violet colour, though it is commonly called "Blue"; it grows most luxuriantly in very moist ground, usually on the low banks of streams or in the marshes, for it is there that

"The purple violets lurk,

With all the lovely children of the shade."

Poets have ever loved and praised the Violet. The Bard of Aron sang of how

"Violets blue,

And lady-smocks all silver white,

And cuckoo-buds of yellow hue

Do paint the meadows with delight";

later causing Oberon to relate:

"I know a bank whereon the wild thyme blows, Where ox-lips and the nodding violet grows."

Milton tolel of the

"Vinlet embroiclered vale"; 
PLATE LV

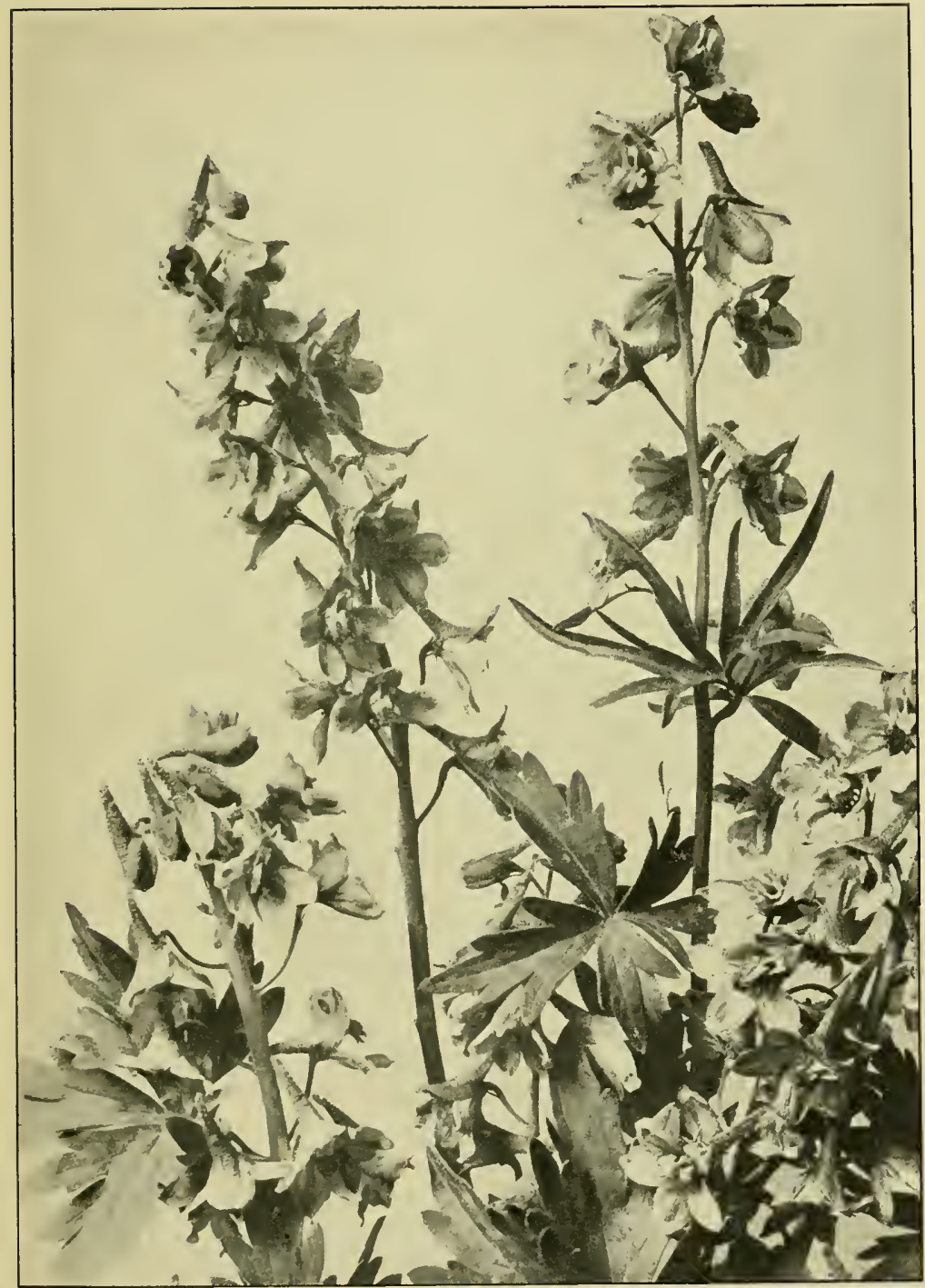

Mountain LaRkspur

(Delphinium Brownii) 

PLATE LVI

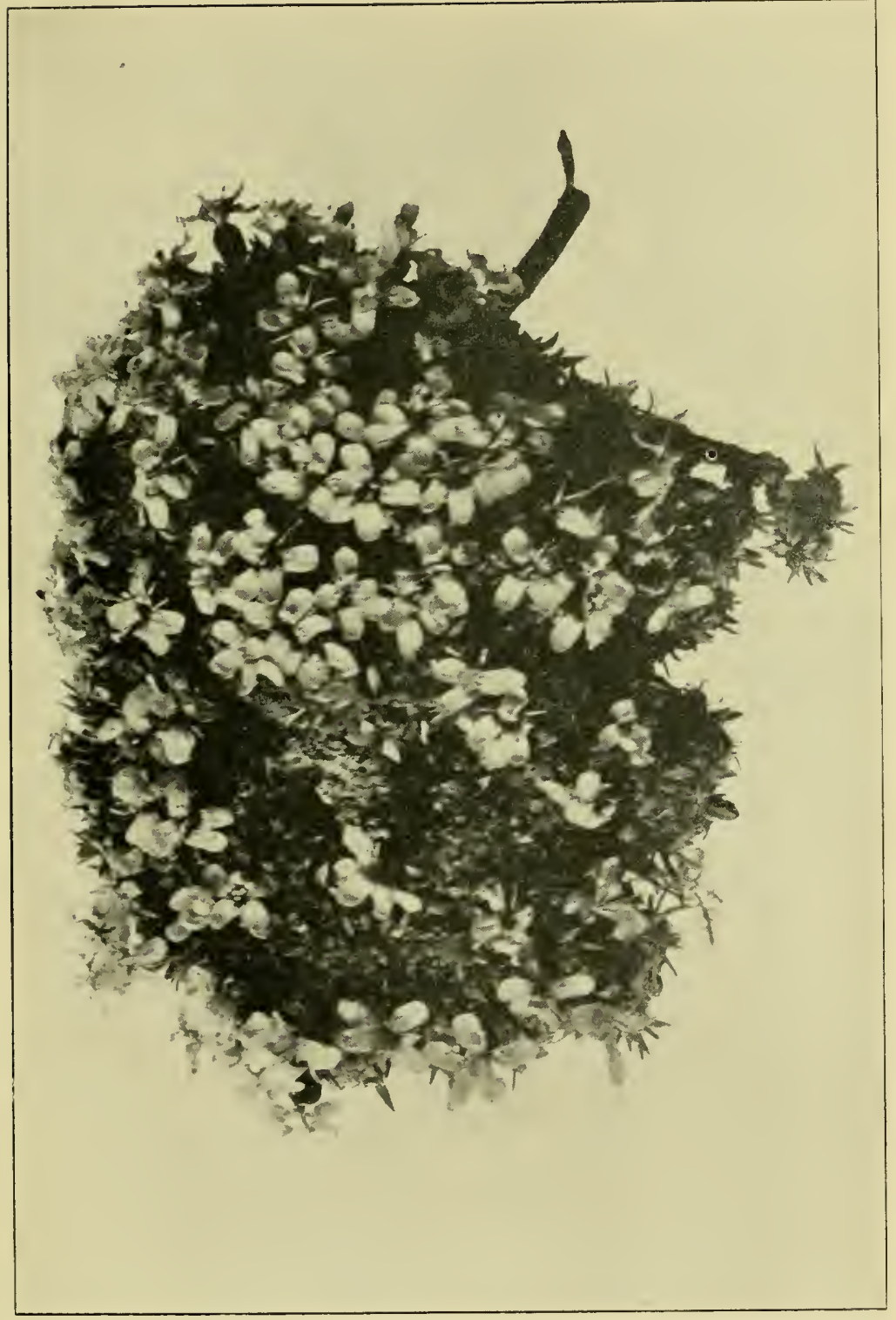

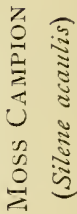



and Scott claimed that

"The violet in her greenwood bower,

Where birchen boughs with hazel mingle,

May boast herself the fairest flower

In forest glade or copsewood dingle."

Long before Shakespeare's day, however, the ancient Arabians sang its praise. It was the favourite flower of Mahomet, just as it was that of Napoleon in modern times, and has since become the emblem of the Bonapartists, who still wear it as a token of their devotion to a lost cause, remembering, perhaps, Shakespeare's proverb that

"Violet is for faithfulness."

No legitimist in France will ever wear these flowers.

The Early Blue Violet has five large petals that are hairy at the base, the lower one being marked with a tiny, darkveined yellowish-white patch on its face, and protruding at the back into a small rounded spur. The leaves are broad and conspicuously veined, many of them being folded inwards when young.

$V$. adunca, or Dog Violet, is a smaller dark purple or white species which grows on dry ground and sends out runners that bear many blossoms.

\section{MOSS CAMPION}

\section{Silene acaulis. Pink Family}

Closely cespitose, one to two inches high. Leaves: linear, crowded. Flowers: small, solitary, subsessile or slightly raised on naked curved peduncles; calyx narrowly campanulate; petals purple or white, obcordate.

The Moss Campion will only be found by those who climb to great altitudes, for it always grows near the highest summits of the mountains and has been discovered at the immense elevation of 10,000 feet. It is a dwarf arctic-alpine plant. 
The tiny leaves, which are very numerous and extremely narrow and pointed, distinguish it from Saxifraga oppositifolia, or Mountain Saxifrage (see page 2 I 3), which has similar flowers but distinctly broader leares.

Close to the eternal snows, where the last line of vegetation grows prostrate upon the earth, so rare the air, so scarce and poor the soil,

"There, cleaving to the ground, it lies

With multitude of purple eyes

Spangling a cushion green like moss."

Surcly Vordsworth must have found the Moss Campion amongst his beloved Grasmere Hills, otherwise he could not have penned so perfect a description of its starry flowers with their five purple or very occasionally white petals wide-blown by the mountain breeze.

The Moss Campion has a very large tap-root, and springing from it are the slender branching stems, which form dense tufts from six to twenty inches in diameter and resemble a coarse moss. Down into these tufts the flowers are closely set.

\section{WILD FLAX}

\section{Linum Lequisii. Flax Family}

Stems: slender, erect. Leaves: crowded, sessile, oval-linear, acute. Flowers: on long pedicels; sepals oval, obtuse: petals five, large, blue, fugacious.

A slender dainty plant, which bends and bows to every passing breeze, and bears terminal clusters as well as racemes of Jovely cerulean flowers.

"Blue were her cyes as the fairy flax,"

wrote I ongfellow, and if you once see the wonderful blue of these blossoms you will well understand the compliment intended, for they are a marvellous colour, and so frail and translucent that they wither at a single touch, while the delicately veined petals fall almost as soon as they develop into 
PLATE LVII

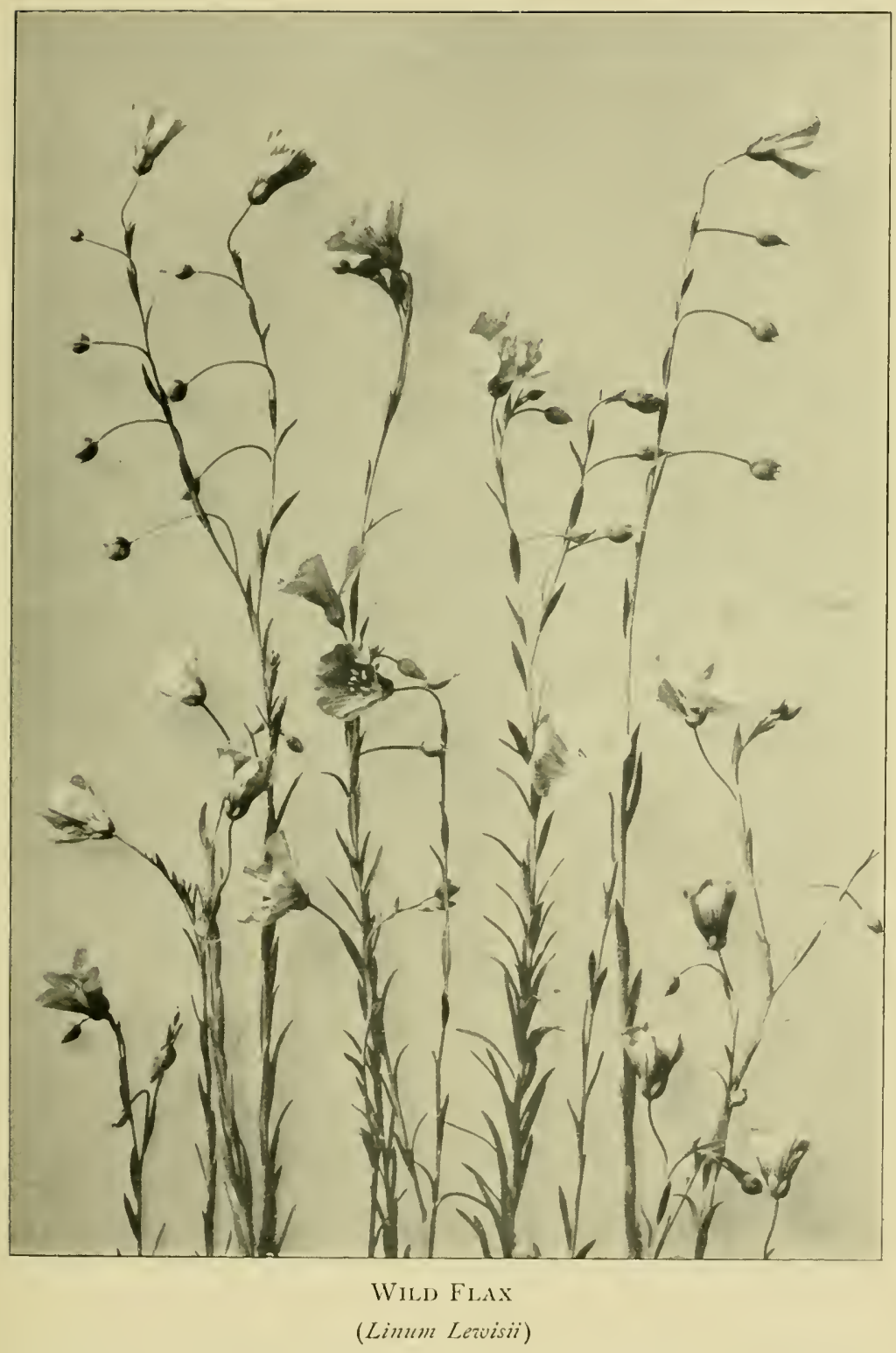





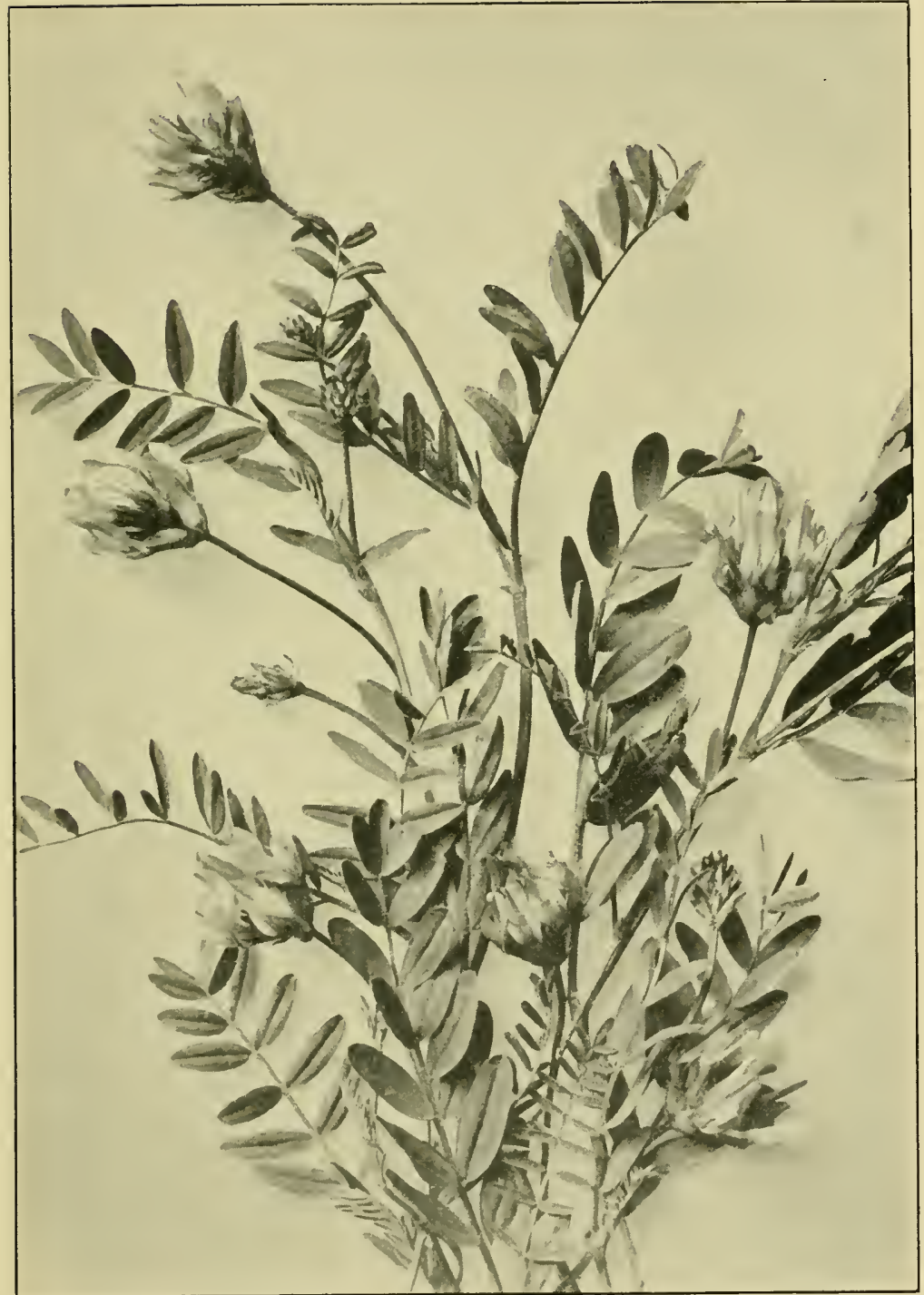

Ascending Vetch

(Astragalus adsurgens) 

the perfect flowers; the stems, on the contrary, though slim, are remarkably tough. A really blue flower is a rarity in the mountains. There are many mauves, heliotropes, violets, purples, and lilacs, but few true blues.

The word linum comes from the Celtic word lin, meaning "thread," and from it also is derived the English word "linen," together with all its variations. The seeds of the Flax contain oil.

\section{ASCENDING VETCH}

\section{Astragalus adsurgens. Pea Family}

Stems: rather stout, ascending or decumbent. Leaves: odd-pinnate; leaflets oval to linear-oblong, obtuse, fifteen to twenty-five, peduncles exceeding the leaves. Flowers: erect, in short dense spikes; tube of the calyx long-campanulate, twice as long as the setaceous teeth, subvillous with partly black hairs; petals clawed; standard erect, ovate; wings oblong; keel obtuse. Fruit: pods erect, sessile, coriaceous.

This is a common species of purple Vetch in the mountain regions. It has much foliage, composed of from fifteen to twenty-five tiny oblong leaflets borne on each of the leaf-stalks, which branch from the main stems. The flowers grow in dense roundish heads, and the little leaflets are rounded and entire at the apex.

Each incliviclual flower, like many of those of the Pea Family, is composed of five irregular petals, the large upper one, called the standard, being turned backwards when in full bloom, and the two sicle ones forming wings, while the two lower ones are united to form a kind of pouch, called the keel, which encloses the stamens and style.

The traveller will note that an easy way to distinguish Astragalus adsurgens from Orytropis viscida (which it much resembles) is by observing two things. In the first place, the flower-stalks of the Astragalus branch out from all parts of the main stems of the plant, together with the leaf-stalks; whereas the flower-stalks of the Oxytropis are naked and grow directly 
up from the base of the plant. In the second place, the keel of the Astragalus flower is rounded, whereas that of the Oxytropis is very pointed.

A. leypoglottis, or Purple Vetch, rery closely resembles the preceding species, but may be distinguished from it by the fact that its leaflets are indented or notched at the tips, whereas those of the Ascending Vetch are slightly rounded and perfectly entire.

A. alfinus, or Alpine Vetch, is a dainty pale mauve species, with small loosely flowered heads and delicate foliage. It is frequently found at very high altitudes.

A. Macounii, or Macom's Vetch, is a tall plant with sparse foliage and a few long loosely flowered heads of pale manve, or white tinged and edged with mauve. The stems grow very erect and are quite slender. It usually is found in rocky places.

A. convallarius, or Slender Vetch, is a lovely fragile species, quite unmistakable by reason of its very fine grass-like stems, tiny, narrow, silky leaflets, and little, scanty, pinkish-mauve blossoms, that grow far apart in long slender racemes, giving the plant a beautiful feathery appearance.

\section{INFLATED OXYTROPE}

\section{Oxytropis podocarpa. Pea Family}

Acaulescent, or nearly so, villous-pubescent. Leaves: pinnate; leaflets linear, obtuse. Flowers: peduncles one-to-two flowered, scarcely exceeding the leaves: calyx densely dark-pubescent: petals clawed; standard erect; wings oblong; keel erect, its apex mucronate. Fruit: pods much inflated, oroid, sessile in the calyx.

An arctic and alpine plant, which grows only from one to four inches high and has violet flowers and tiny very hairy stalks and leaves. The main stems grow partly underground and are imbricated, - that is to say, they are covered with numerous small overlapping leaves; but the pods are the most noticeable feature, being abnormally large and inflated. This plant is frequently found growing flat upon the ground. 
PLATE LIX

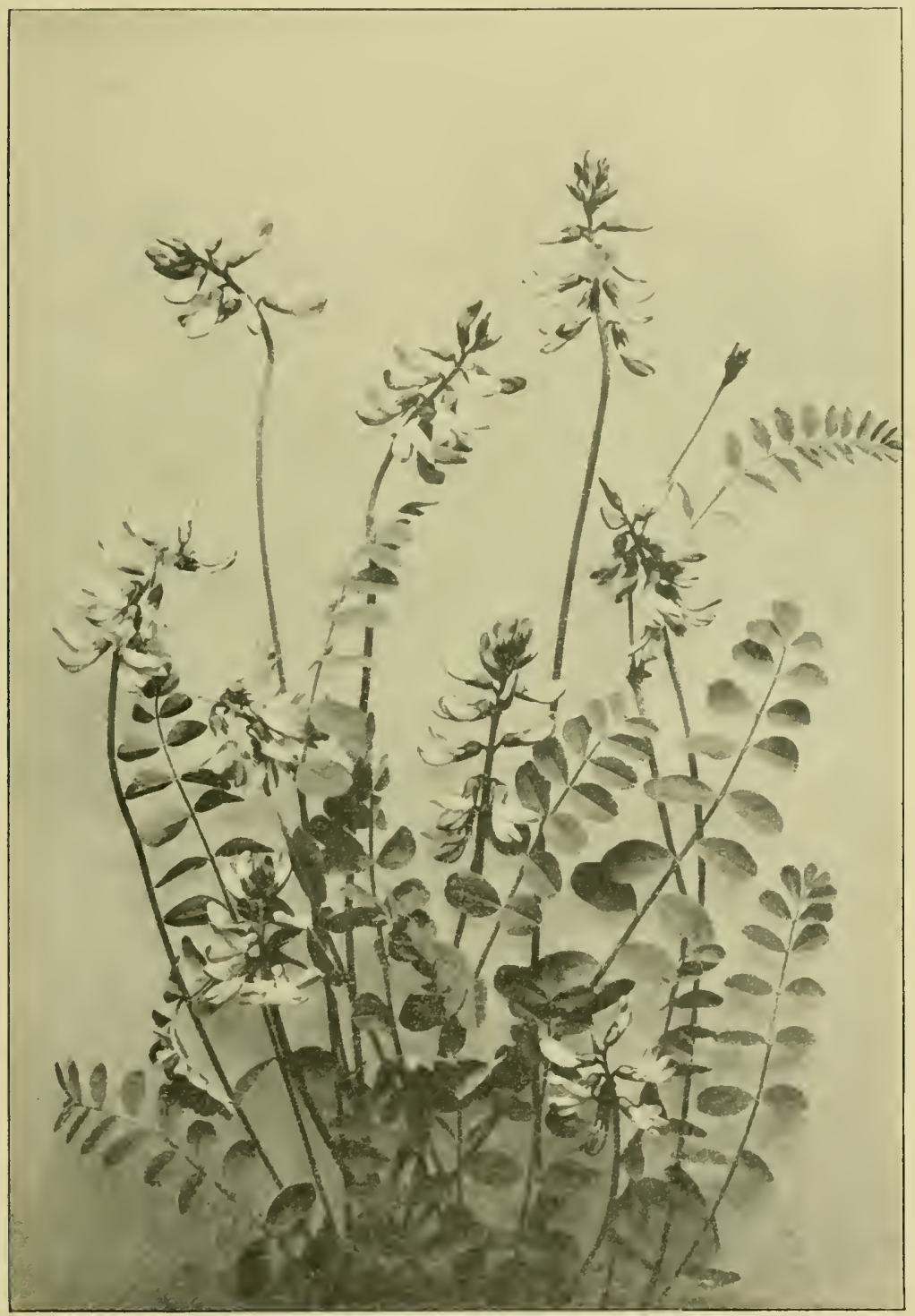

AIPINE VI:TCH

(Astragalus alpinus) 



\section{ALPINE OXYTROPE}

Orytropis riscida. Pea Family

Stems: viscid-pubescent. Leaves: odd-pinnate; leaflets in numerous pairs, oblong-lanceolate, somewhat acute. Flowers: peduncles longer than the leaves; spikes subcylindrical; teeth of the calyx subulate, about the length of the tube; legumes short, terete, acuminate.

As remarked before, Oxytropis differs from Astragalus in having flowers with very pointed keels and long naked flower-stalks that grow up directly from the base of the plant; also its flower-spikes are more elongated than those of the Ascending and Purple Vetches, which are roundish. The Alpine Oxytrope is a hairy, rather sticky plant, and bears blossoms of many shades of gray-blue, violet, mauve, purple, and creamy white.

\section{SHOWY OXYTROPE}

\section{Oxytropis splendens. Pea Family}

Densely silvery, silky villous, acaulescent, tufted. Leaves: long, erect; leaflets very numerous. Flowers: in dense spikes; peduncles exceeding the leaves. Fruit: pods ovoid, erect.

This plant is rightly named the Showy Oxytrope, for its handsome bright purple-blue or purple-pink flowers, growing in dense spikes on the top of the long straight stalks, and its quantity of silvery silky foliage render it a remarkably handsome member of the Pea Family. The whole plant, inclucling the stalks, leaves, and calyx, is extremely woolly.

\section{PURPLE HEDYSARUM}

\section{Hedysarum boreale. Pea Family}

Stems: erect, glabrous, generally simple. Leaves: odd-pinnate, shortpetioled; leaflets oblong, obtuse, and often mucronate at the apex. Flowers: in long loose racemes, deflexed.

A tall purple species of Hedysarum with very narrow loosely flowered racemes and rather large leaflets. The white species, 
H. boreale var: albiflomm, referred to in the White to Green Section, bears rather finer blossoms, its racemes being more closely flowered. In Plate LX the tall flower in the centre is the White IIedysarm, the one to the left being a specimen of the I'urple Hedysarum.

\section{COW VETCH}

Iicia Cracur. Pea Family

Stems: tufted, slender, weak, climbing or trailing. Leaves: pinnate, tendril-bearing, nearly sessile; leaflets cighteen to twenty-four, linear, obtuse, mucronate; peduncles axillary. Flowers: in spike-like dense racemes, reflexed. Not indigenous.

A lorely climbing or trailing Vetch, with dense spike-like racemes of deep purple-blue flowers and quantities of delicate foliage; the leaves, which are pinnately divided into numerous tiny leaflets, having thread-like tencrils at their tips.

I: Amcricana, or American Vetch, has the same nearly sessile pinnate leaves and slender weak stems as the preceding species. It also climbs and trails over every bush and shrub in its vicinity, clinging to them by means of its tiny tendrils; but it differs entirely from $V$. Craced in its flowers, which are larger, more maure in hue, and grow in a scanty, very loose fashion, as opposed to the dense spike-like racemes of the Cow Vetch.

To see the mountain woods blued by these two graceful plants recalls Emerson's reference to how

"The million-handed Painter pours

Opal hues and purple dye"

out upon the flowers of the forest.

The Astrugalus, Orytropis, Hedysarmm, and Ficie all belong to the l'ea Family, and therefore their Howers are all papilionaccons; that is to saly, they have irregular butterfly-shaped blossoms. 
PLATE LX

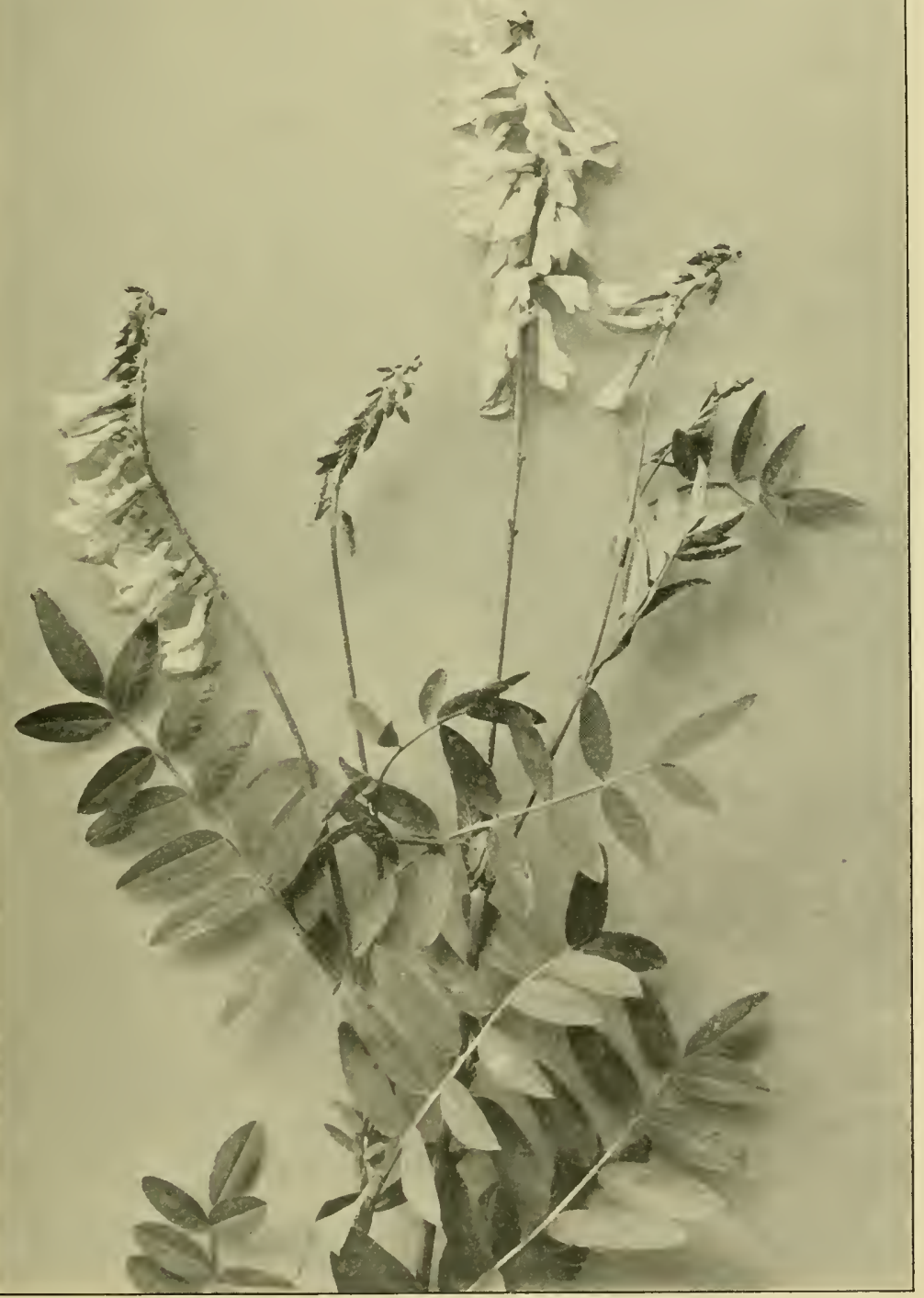

PURPLe Hedrsarun (hedysarum boreale)

WHITE HED'SARUM (Hed'sarnm boreale a'ar. albifornm) 

PLATE LXI

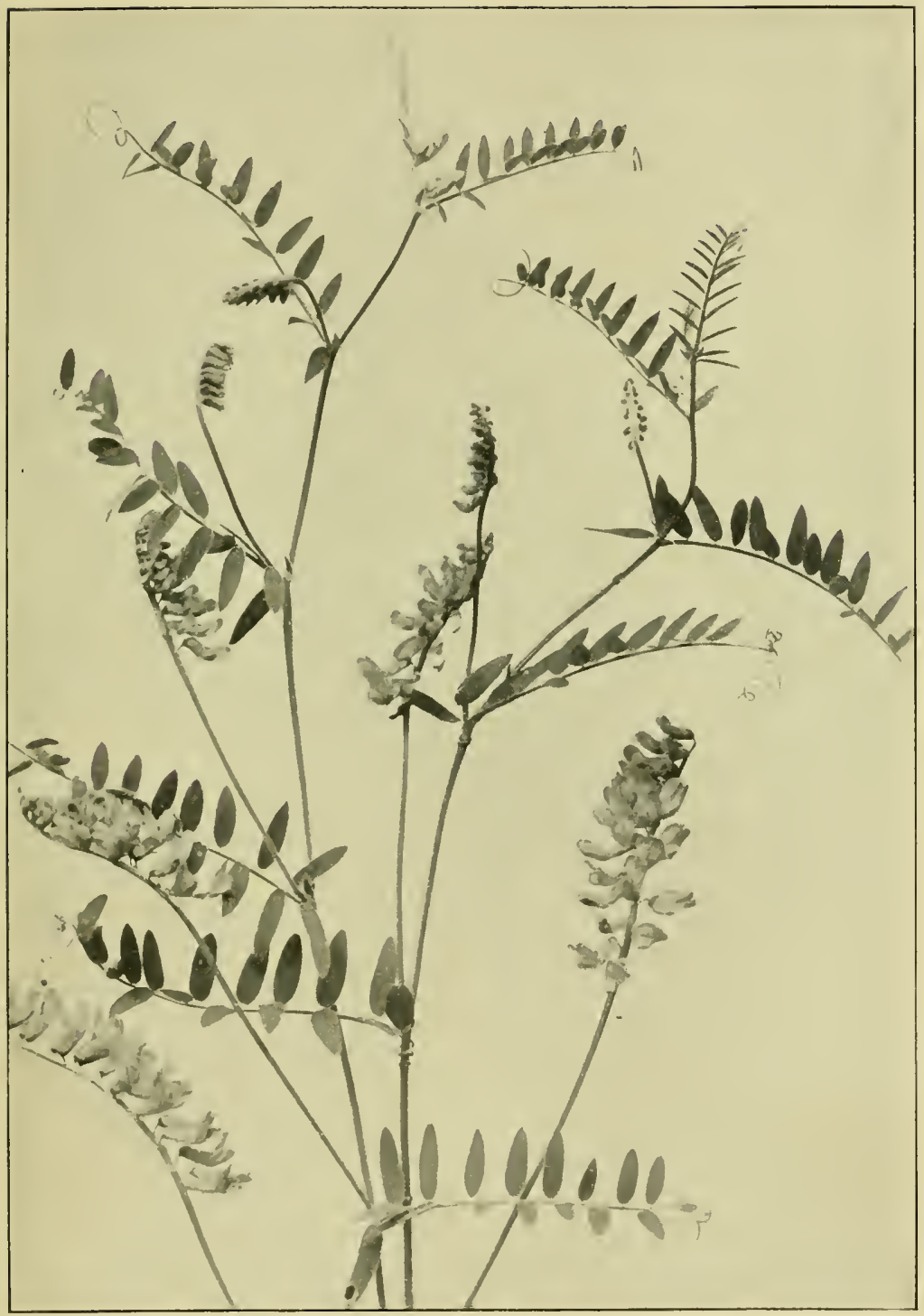

C()W VetCH

(Iricia Craca) 



\section{MOUNTAIN SAXIFRAGE}

Saxifraga oppositifolia. Saxifrage Family

Stems: prostrate, densely leafy. Leaves: sessile, ovate, nearly orbicular, persistent, keeled, fleshy, opposite or imbricated in four rows, the margins ciliate. Flowers: solitary, nearly sessile; calyx-lobes obtuse, much shorter than the obovate purple petals.

The simple description of Silene acaulis, or Moss Campion, given on page I97, is applicable in several particulars to this Mountain Saxifrage, which is also a dwarf arctic-alpine flower and only grows at great altitudes. The chief difference between the two plants lies in the leaves, which in the Campion are extremely fine and narrow and in the Saxifrage are egg-shaped and thickish, with a strongly marked keel and hairy margins. The stems of the Saxifrage are prostrate and very leafy, and the flowers are purple and grow almost flat upon the ground.

It was John Keble who first drew our attention to the fact that they are

"The loveliest flowers that closest cling to earth."

It was also evidently to some such prostrate alpine plant as the Mountain Saxifrage that he referred when he wrote:

"Bloom on then in your shade, contented bloom, Sweet flowers, nor deem yourselves to all unknown.

Heaven knows you, by whose gales and dews ye thrive;

They know, who one day for their altered doom

Shall thank you, taught by you to abase themselves and live."

\section{LARGE PURPLE ASTER}

Aster conspicuus. Composite Family

Stems : stout, rigid. Leaves: ovate, oblong, acute, serrate, veiny. Flowers: in numerous corymbosely cymose heads; involucre broadly campanulate, its bracts in several series; rays in a single series, not very numerous; disk-flowers tubular, perfect. 
In August or September the mountain meadows and forests teem with many of these flowers, for then

"Everywhere the purple asters nod,

And bend, and wave, and tlit."

They are the pretty heralds of Autumn, some of them tall, handsome, and stately, like the Large Purple Aster; some quite small, some big and branching, and others again straight and slender, but all tending to glorify the earth. The Aster conspicums is the largest and handsomest of all its tribe, as its name suggests. It is very branching and has large leares that are sharply toothed; while the involucre, or green cup which holds the flower, is curiously formed by several series of tiny narrow-pointed bracts, which stand out horizontally and give it a fringed appearance. The rays of this Aster are a lovely bright purple, and the disk-flowers in the centre are golden yellow.

A. Fremonti, or Fremont's Aster, is a very common species. It also has purple rays, but rather brownish-yellow diskflowers. All the Asters consist of numerous, tiny, tubular disk-flowers crowded together in a close cluster and surrounded by the rays, or ray-flowers, which are strap-shaped, the whole being held together in a green cup, or involucre, of bracts. The leaves of Fremont's Aster are quite smooth at the edges.

The Asters are much-prized flowers, because they come to us at a season when the whole world is walking in russet garb along a penitential pathway that leads to winter's frosty prison. Only the Golden-rods and Asters are left to linger through the soft gray days of late autumn, and what could be more beautiful than these blossoms of purple and gold, which, where the sun strikes light with his ruddy lanees, bejewel the burnished lustre of bare branches and brown fallen leaves?

A. foliaceus, or Leafy-bracted Aster, is a stout-stemmed erect species, with violet, purple, or white rays. It has many 


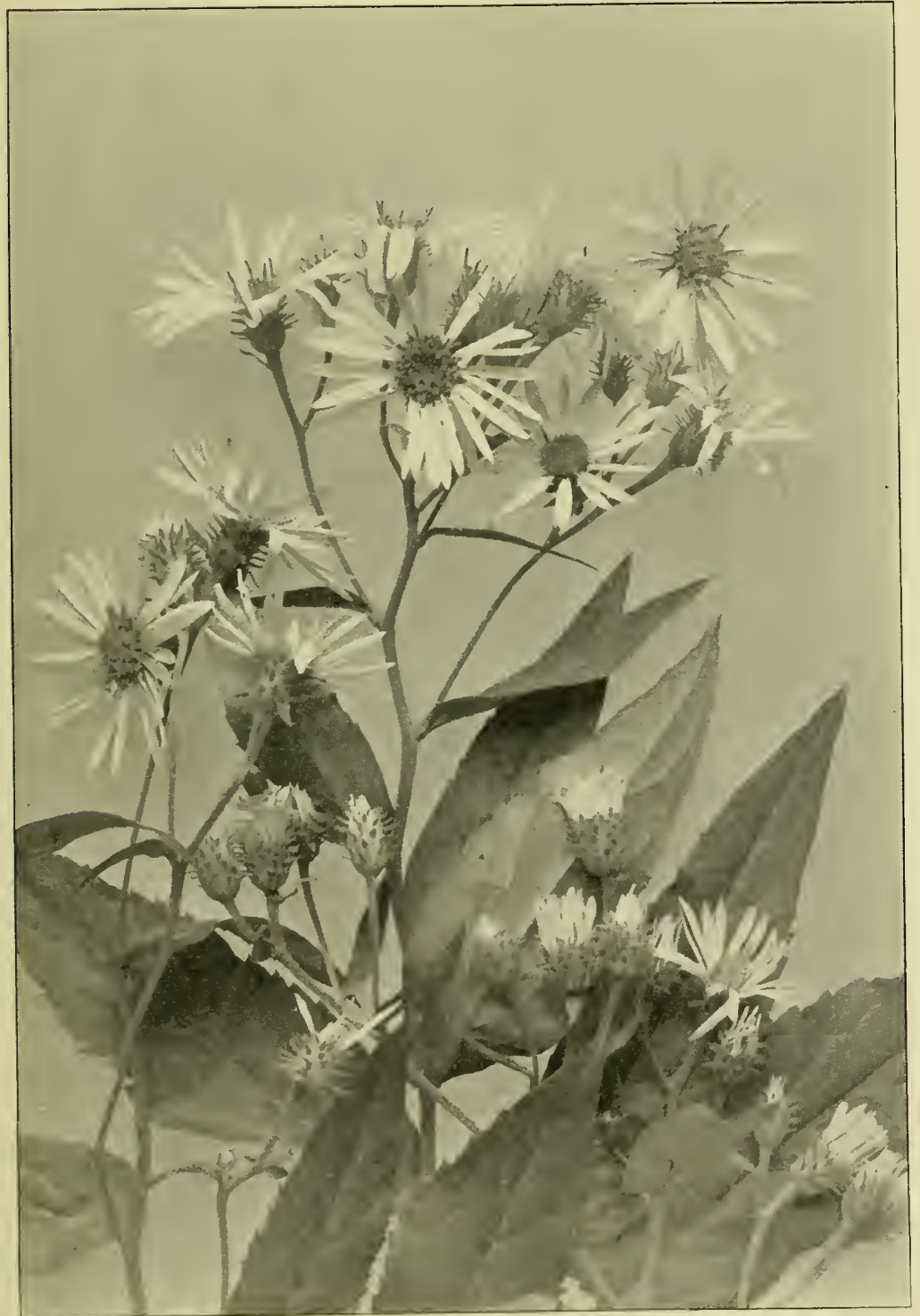

Latrae purple Aster

(Aster conspicuus) 

PLATE LXIII

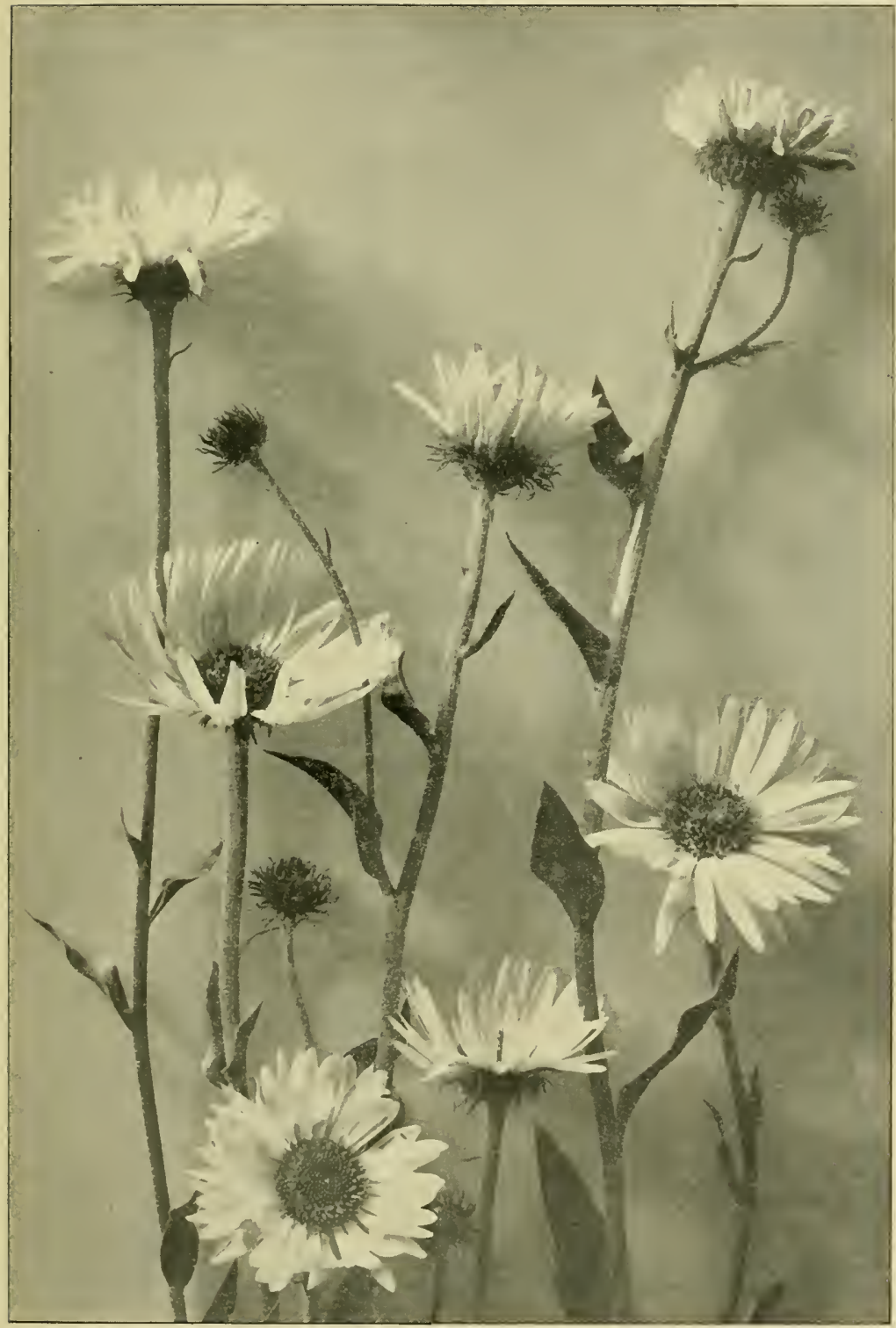

Large Purple Fleabane

(Enigeron salsuginosus) 

flowers growing on short stalks, which spring out at intervals from the axils of the clasping smooth-edged leaves, all the way up the long main stems; and the bracts of the green involucre are very conspicuous, especially the outer and lower series, which spread forth horizontally and are almost like tiny leaves. This Aster usually grows near water.

A. Engclmannii, or Engelmann's Aster, is a rather tall robust plant, of coarse appearance, with clusters of purple flowers, each one growing on its own individual axillary stalk, or else in a terminal cyme.

A common English name for Asters is Michaelmas Daisies, because they bloom at the feast of Saint Michael, according to

"The calendar,

Faithful through a thousand years,

Of the painted race of flowers,

Exact to days, exact to hours."

\section{BLUE FLEABANE}

\section{Erigeron acris. Composite Family}

Stems: hirsute-pubescent, slender, simple or branched. Leaves: pubescent, entire, the lower ones spatulate, the upper ones oblong, sessile; involucre hemispheric, its bracts linear, hirsute. Flowers: rays numerous, tubular; pistillate flowers filiform; pappus simple, copious.

A very common species of Fleabane, which has numerous small flowers growing in a cluster at the top of each slender stem, and also a few solitary axillary blossoms lower down. The whole plant is hairy, the lower leaves being spatulate and the upper ones oblong, all with smooth perfect margins.

The Fleabanes differ from the Asters in one very essential particular, namely, that the rays of the former are much narrower and very much more numerous than those of the latter, forming a thick fine fringe round the edge of the flowers. Also the Fleabanes bloom earlier in the season. They are extremely prolific. 
E. Plitaddplicus, or Lavender Fleabane, has a thick, finely cut lavender fringe encircling its yellow disk of tiny tubular florets. The leaves are very clasping and toothed, and the rays often number one hundred and twenty.

E. unifloms, or Arctic Fleabane, is a very tiny dwarf plant. growing from one to six inches high, and found only on the loftiest mountain summits. It has a single slender stem, which is clothed at the base by a small cluster of smoothmargined hairy leaves; a few little narrow leaves also grow higher up. At the top is a solitary purplish flower. The whole plant is very hairy and woolly.

E. lanatus, or Alpine Fleabane, is also a species which grows at great elevations. It has both purple and white flowers, and is covered with a soft, whitish, woolly coating.

E. salsuginosus, or Large Purple Fleabane, is the king of its tribe. It has very large and lovely purple flowers, with big yellow disks and a few small, thick, smooth leaves clinging to its stout downy stems. The rays number from fifty to seventy, and the bracts of the involucre are narrow and spreading. This particular Fleabane is quite unmistakable, for it is much larger and handsomer than any of the other mountain species, and makes the alpine meadows and slopes quite gay during its flowering season, which is in the early autumn.

\section{WAVY-LEAVED THISTLE}

\section{Cnicus undulatus. Composite Family}

Persistently white-tomentose throughout. Stems: stout, leafy. Leaves: lanceolate in outline, acute, sessile, undulate, lobed, the lobes dentate, triangular, very prickly. Flowers: solitary at the ends of the branches.

This redelish-purple Thistle grows from one to three feet high and is a fine handsome plant with large long leaves, whose edges are wavy and triangularly lobed, the lobes being sharply toothed and rery prickly. The big flower-heads grow 
PLATE LKIV

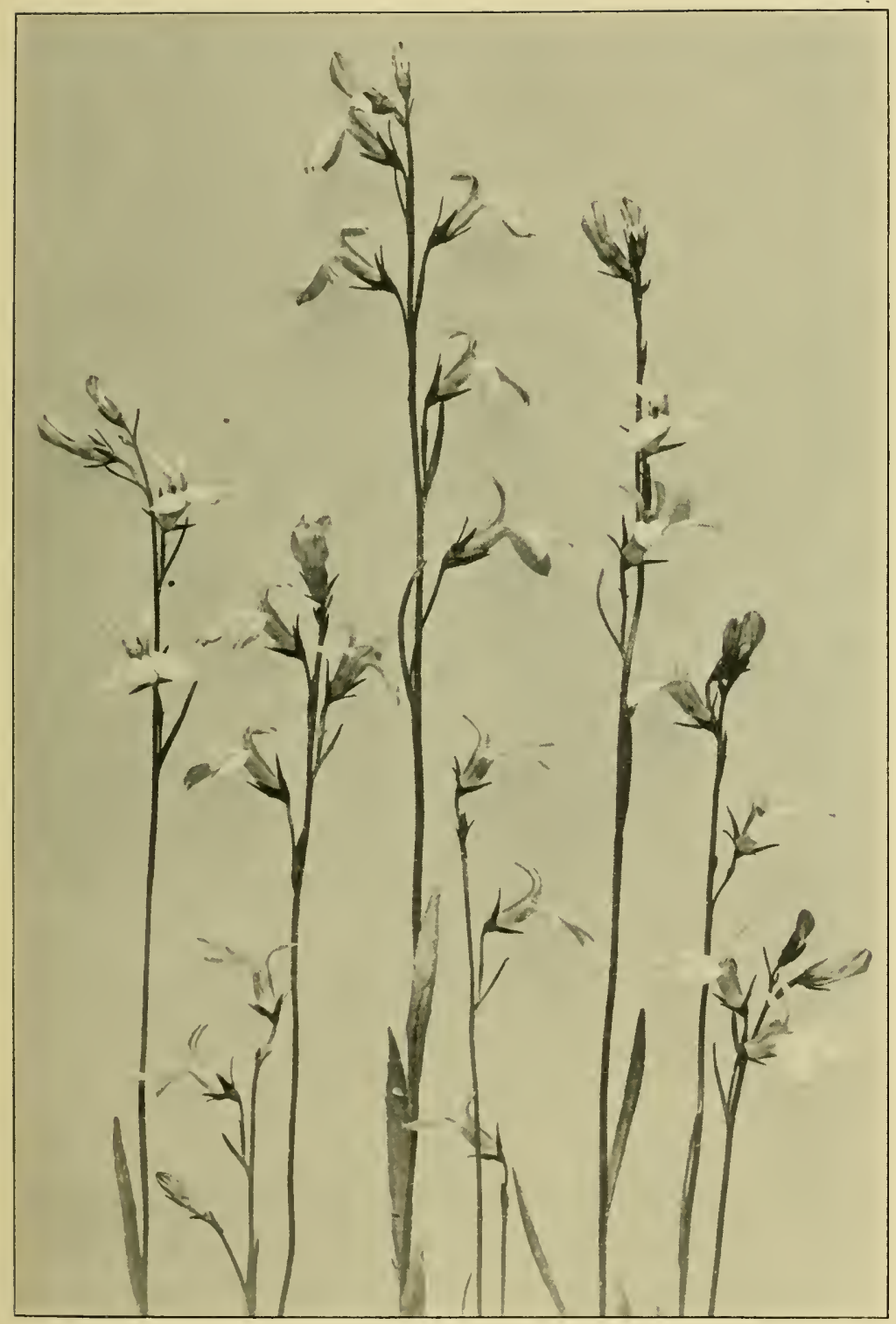

BROOK LOBELIA

(Lobelac Kialmii) 

at the ends of the branches and are surrounded by large involucres of prickly bracts.

Every traveller knows that the Thistle is the national floral emblem of Scotland, and has been ever since that day when a barefoot Danish soldier, stepping inadvertently upon its spines, gave a cry of pain which aroused the sleeping Scottish camp and saved Scotland. The motto which Scotsmen affix to this flower is "Icmo me impune lacessit" (No one touches me with impunity), or in the vernacular, "Ye maun't meddle wi' me." And assuredly we are quite content to leave it alone in its prickly glory, only pausing a moment in passing to admire its fine richly coloured flowers.

\section{BROOK LOBELIA}

\section{Lobelia Kalmii. Lobelia Family}

Stems: leafy, glabrous. paniculately branched. Leaves: lower ones spatulate, obtuse, almost entire; upper ones sessile, linear, acute. Flowers: in loose racemes; caly $x$-tube turbinate, hemispheric, lobes lanceolate; corolla-tube straight, oblique, divided to the base on one side, two-lipped, irregularly five-lobed.

Those who are familiar with the cultivated garden species of Lobelia will easily recognize the mountain Brook Lobelia, which usually grows at the extreme edge of a stream, or half immersed in some warm wet swamp, where its grass-like stems, bearing their racemes of sky-blue blossoms, spring up in little companies amongst the water-weeds, the Butterworts, and the Fly-spotted Orchis.

\section{HAREBELL}

\section{Campanula rotundifolia. Campanula Family}

Stems: slender, erect, simple or branched. Leaves: basal ones orbicular or broadly ovate to cordate; cauline ones sessile, linear. Flowers: buds erect on slender pedicels, flowers drooping or spreading; corolla campanulate, five-lobed. 
These bells of brilliant purple-blue are familiar to every traveller in the temperate zone, for from "Bonnie Scotland" to the Pacific Slope the Harebell graces many a hill and dale.

Poets in every age have sung of this flower, which is the real Bluebell of Scotland, the favourite floral emblem of the "Land o' cakes and brither Scots," for, as the old song says :

"Let the proud Indian boast of his jessamine bowers, His pastures of perfume, and rose-coloured dells, While humbly I sing of those wild little flowers,

The bluebells of Scotland, the Scottish bluebells."

The name rotundifolia refers to the roundish heart-shaped basal leaves of the plant, which wither carly, while the stemleaves, which are numerous, narrow, and pointed, remain. A marked characteristic of these flowers is that, although the buds grow erect on their slender stalks, the full-blown blossoms droop or are horizontal in order to protect their pollen from the rain. The name Harebell refers to the hair-like stems of the plant, and the common term Bluebell is usually reserved for the Wild Hyacinth, which is a very different flower, having thick juicy stalks and resembling the garden species.

The Harebell is extremely hardy and may be found in the crevices of the cliffs, defying the fierce alpine storms or growing on dry wind-swept meadows, or striking its roots into the tiniest patch of soil, so as to gain a foothold on the edge of some terrific precipice, where its delicate bells, so "darkly, deeply, beautifully blue," bend but never break before the blustering gale. This wonderful vitality of the Componula is commemorated by Sir Walter Scott when, describing Ellen in The Lady of the Lake, he say's:

"I: en the light harebell raised its head Elastic from her airy treal." 
PLATE LXV

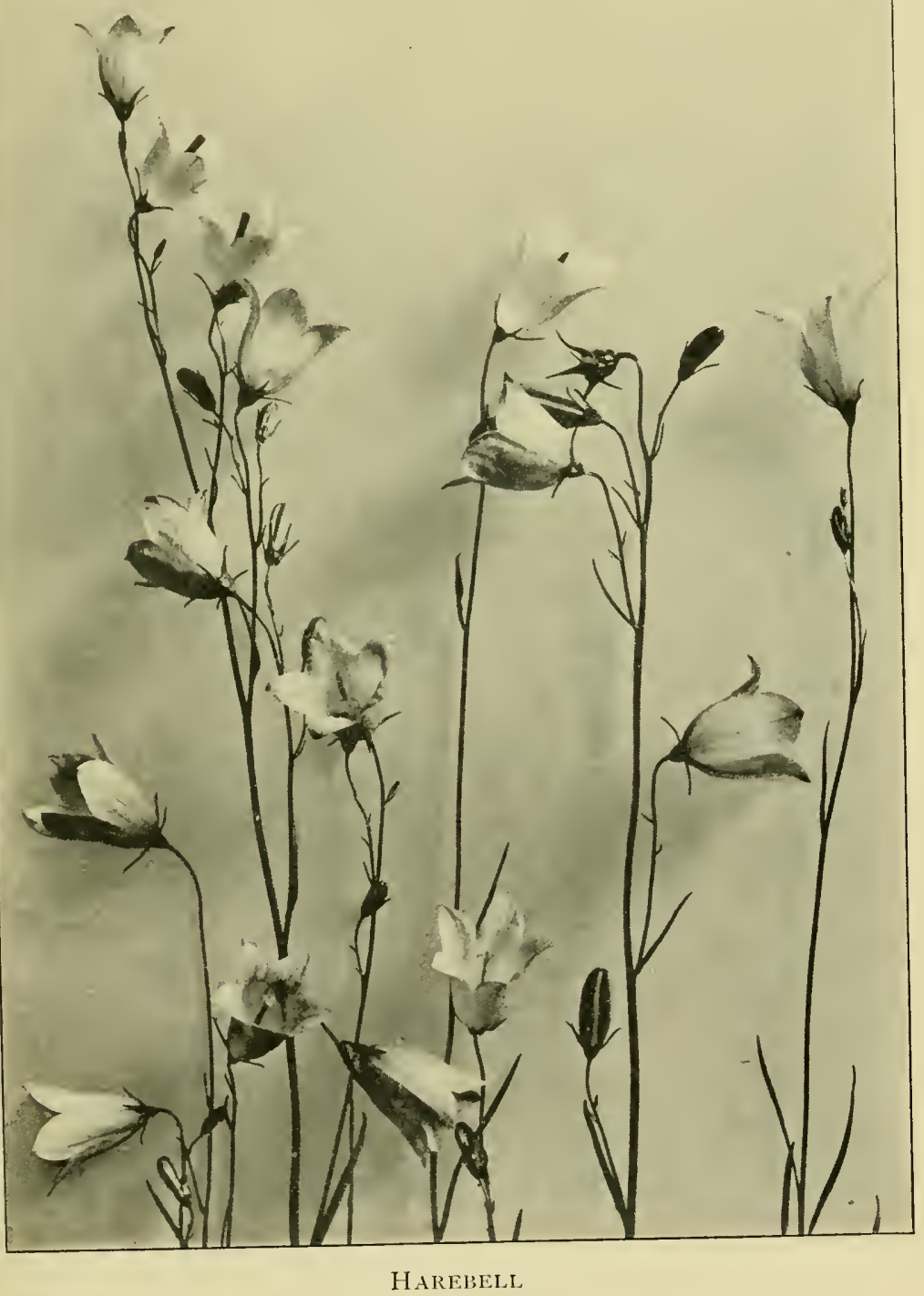

(Campanula rotundifolia) 



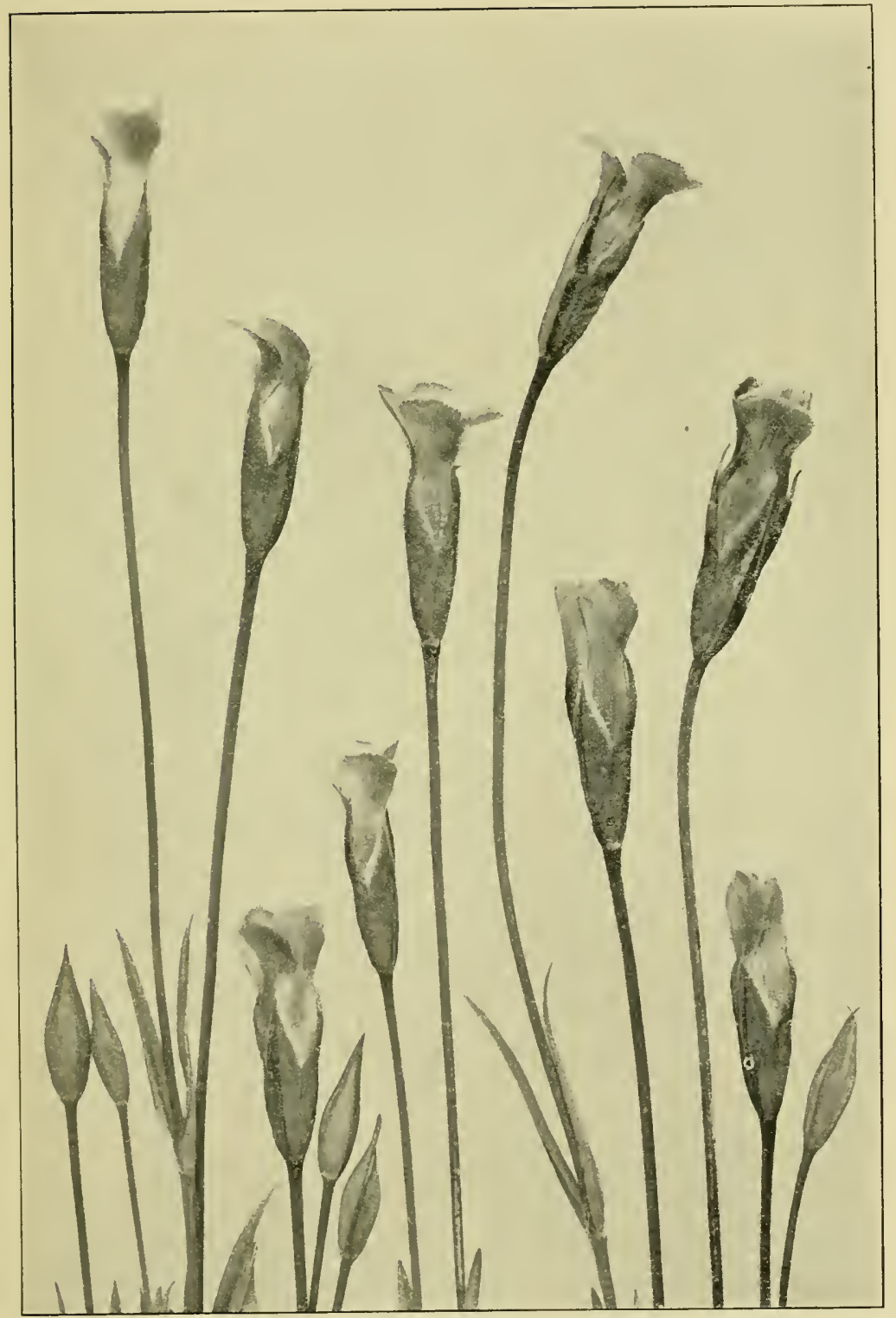

MACOUN'S GENTIAN

(Gentiana Macounii) 



\section{MACOUN'S GENTIAN}

\section{Gentiana Macounii. Gentian Family}

Stems: slender, simple. Leaves: linear. Flowers: solitary at the ends of elongated erect peduncles; calyx-lobes lanceolate, acuminate, their mid-ribs decurrent on the tube; corolla narrowly-campanulate, its lobes spatulate-oblong, fringed on both sides, and almost toothed around the apex.

A lovely deep blue Gentian, found in moist places, but not very common. When the days begin to shorten and the earth is flooded with the final glory of those scarlets and yellows that precede and presage decay, then like a beautiful solemn benediction the Gentians, "coloured with Hearen's own blue," are spread abroad, opening their petals for a while to the sumshine at midday and closing them again suddenly at the first touch of the chill winds that blow off the ice-fields.

In the early fall of the year,

" Then doth thy sweet and quiet eye Look through its fringes to the sky, Blue, blue, as if that sky let fall

A flower from its cerulean wall."

There lies at all times a curious silvery tinge upon the exterior of the four large fringed lobes of the corolla, which are delicately and darkly veined. The two outer calyx-lobes are longer and narrower than the two inner ones, and the buds are very long and pointed. Whenever you try to pick one of these Gentians, you will find that the whole plant comes up out of the ground at the slightest pull. They are extremely elusive flowers, seldom reappearing in the same place for two consecutive years, since, being annuals, and therefore perpetuated by seed alone, their reappearance the following season depends altogether upon the direction of the wind which blows the little hairy scales hither and thither, and by good fortune deposits a few where the moist earth enables them to germinate. 


\section{NORTHERN GENTIAN}

\section{Gentiana acuta. Gentian Family}

Stems: leafy, slightly wing-angled, simple or branched. Leaves: lower ones obovate, obtuse, the upper ones lanceolate, acute at the apex, subcordate at the base, sessile or somewhat clasping. Flowers: numerous, racemose-spicate, pedicelled, leafy-bracted at base: calyx five-parted, the lobes linear; corolla five-lobed, the lobes lanceolate, acute, each with a fimbriate crown at the base.

A very common Gentian is this little Northern species, and it may readily be distinguished by the fringed crown set within the throat of the corolla-tube. The flowers are quite numerous, growing in clusters on short stiff stalks that spring out of the main stem; they are usually pinkish-purple, but sometimes white. The traveller should specially note that the corolla is divided into five lobes at the top, and that the tiny roots grow close to the surface of the soil and are very easily pulled up.

G. propinqua, or Four-parted Gentian, is somewhat like the prececling species, but has larger, brighter blue flowers, which are not nearly so closely clustered together; and it is a much morc graceful plant. The corolla is four-parted, or cut into four lobes, as the name implies, and the calyx is also fourcleft. These Gentians are occasionally white.

G. arctoplizla, or Alpine Gentian, is a tiny clwarf species rescmbling $G$. propinque. It is found at immense altitudes.

G. prostrata, or Dwarf Gentian, has very weak and often procumbent stems. The leaves are covered with a soft white bloom and have white hairy margins, while the flowers arc solitary and of a lovely azure-blue colour, also very occasionally white. It is an exceclingly tiny plant, and has been found at an elevation of 10,000 feet. 


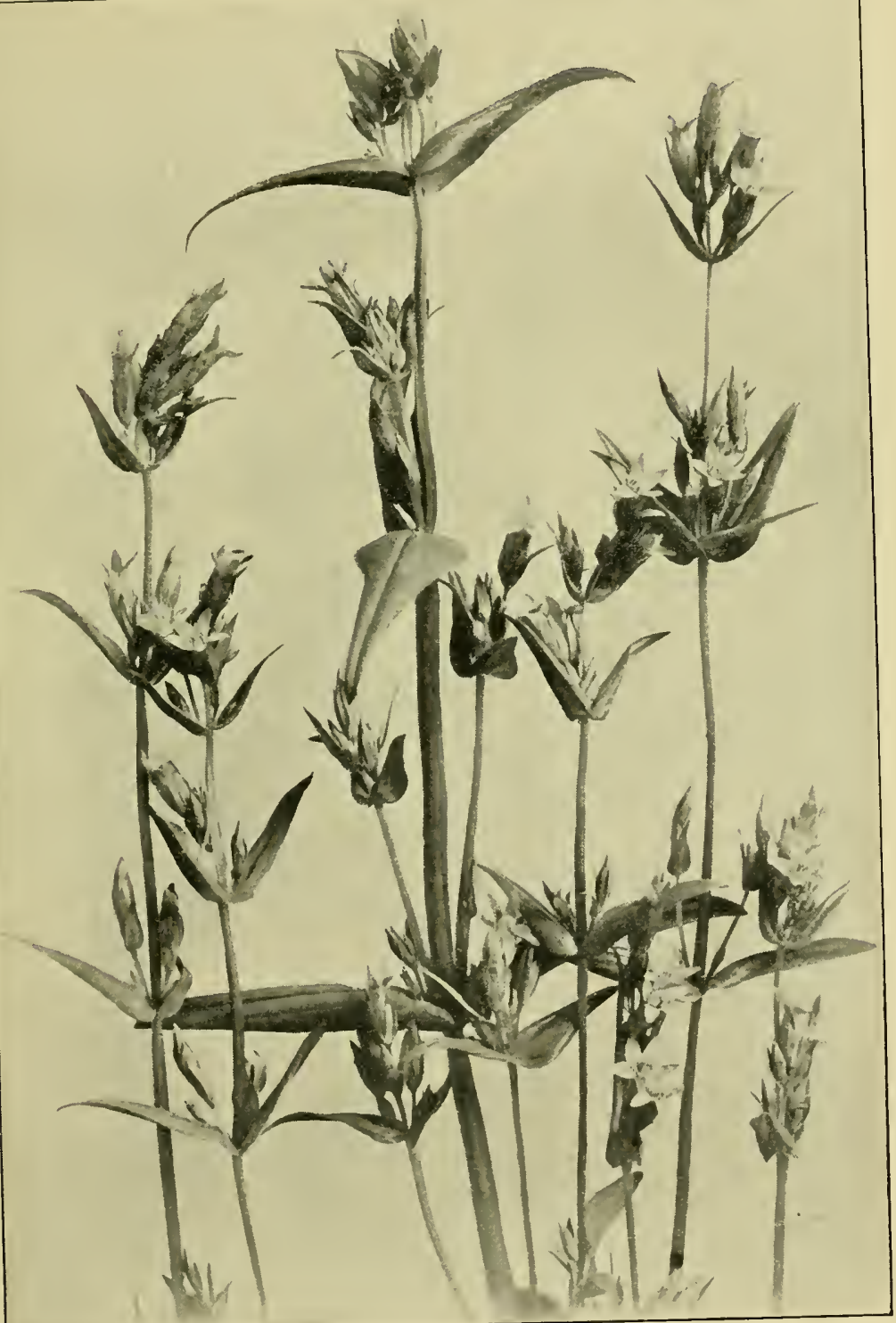

Northern Gextian

(Gentiana acula) 



\section{LARGE GENTIAN}

Gentiana affinis. Gentian Family

Stems: clustered from deep roots. Leaves: oblong, obtuse. Flowers: clustered in the axils of the upper leaves; calyx-lobes linear, unequal; corolla long, narrowly funnel-form, its lobes ovate, entire, acute or mucronate, spreading.

In this tall handsome Gentian there is a very beautiful contrast between the rich green foliage and the azure-blue flowers. These flowers grow in clense clusters among the leaves on the top of the stems; each one has a large, gray, greenish-blue corolla, divicled into five spreading lobes, which are of a wonderful cerulean hue inside, marked and spotted with white. The tips of these lobes are very pointed, and sometimes the green calyx-lobes equal them in length, showing between their divisions, while at other times they are quite minute.

G. Forwoodii, or Blue Gentian, resembles the preceding species, but has a decidedly smaller corolla, with shorter, rounder lobes, and, most remarkable of all, the green calyx has no vestige of any lobes or teeth whatsoever, but is perfectly bellshaped. The lobes of the corolla are entirely blue and have no white spots or marks on them. It is a handsome massive plant.

\section{MOUNTAIN PHACELIA}

\section{Phacelia sericea. Water-leaf Family}

Stems: simple, virgate, canescent, leafy to the top. Leaves: pinnately parted into numerous linear and again pinnatifid divisions, silky-canescent. Flowers: in short spikes, crowded in a naked spike-like thyrsus; calyx-lobes linear; corolla very open-campanulate, cleft to the middle; stamens long exserted.

A glorious plant, with rich purple-blue flowers clustered in huge long spike-like panicles, and handsome deeply cleft foliage, which is covered with a soft white down. The long protruding stamens give a feathery appearance to the open bell-shaped 
blossoms, and as it grows at extremely high altitudes, where flowers of any kind are rather rare and large showy ones almost unknown, the Mountain Phacelia is a real treasure-trove to the traveller. It has a very strong disagreeable odour.

\section{FALSE FORGET-ME-NOT}

Echinospermum floribundum. Borage Family

Stems: soft-hirsute, rather strict. Leaves: oblong to linear, entire, sessile. Flowers: in numerous racemes, nearly erect, densely flowered; corolla funnel-form, five-lobed. Fruit: nutlets keeled, papillose-tuberculate on the back, the margins armed with a single row of flat subulate prickles.

There have probably been more arguments between travellers over these flowers than over any other plant that grows in the mountain regions. Ninety-nine persons out of every hundred will gather the lovely sky-blue blossoms, delighting in their beauty and inhaling with joy the delicate fragrance of their perfume, under the firm conviction that it is the True Forget-me-not they are picking; whereas - alas for the shattering of a pretty romance! - it is only the sweetscented blossoms of the False Forget-me-not they are gathcring, which have as usual practised a successful deception upon the unwary.

The False Forget-me-not may, in reality, be easily distinguished from the True species by a very simple fact, which, once understood and noted, will never again be overlooked. When in fruit the False species bears numerous nutlets covered with prickles, in fact tiny burs, which give it the common name of Stickseed, and certainly these little sceds do stick, and stick very fast incleed, to the clothing of persons and the fur of passing animals. The True Forgetme-not has no burs.

The stems and long narrow leaves of the Eithinospommm floribundum are covered with a slight soft down. It grows 


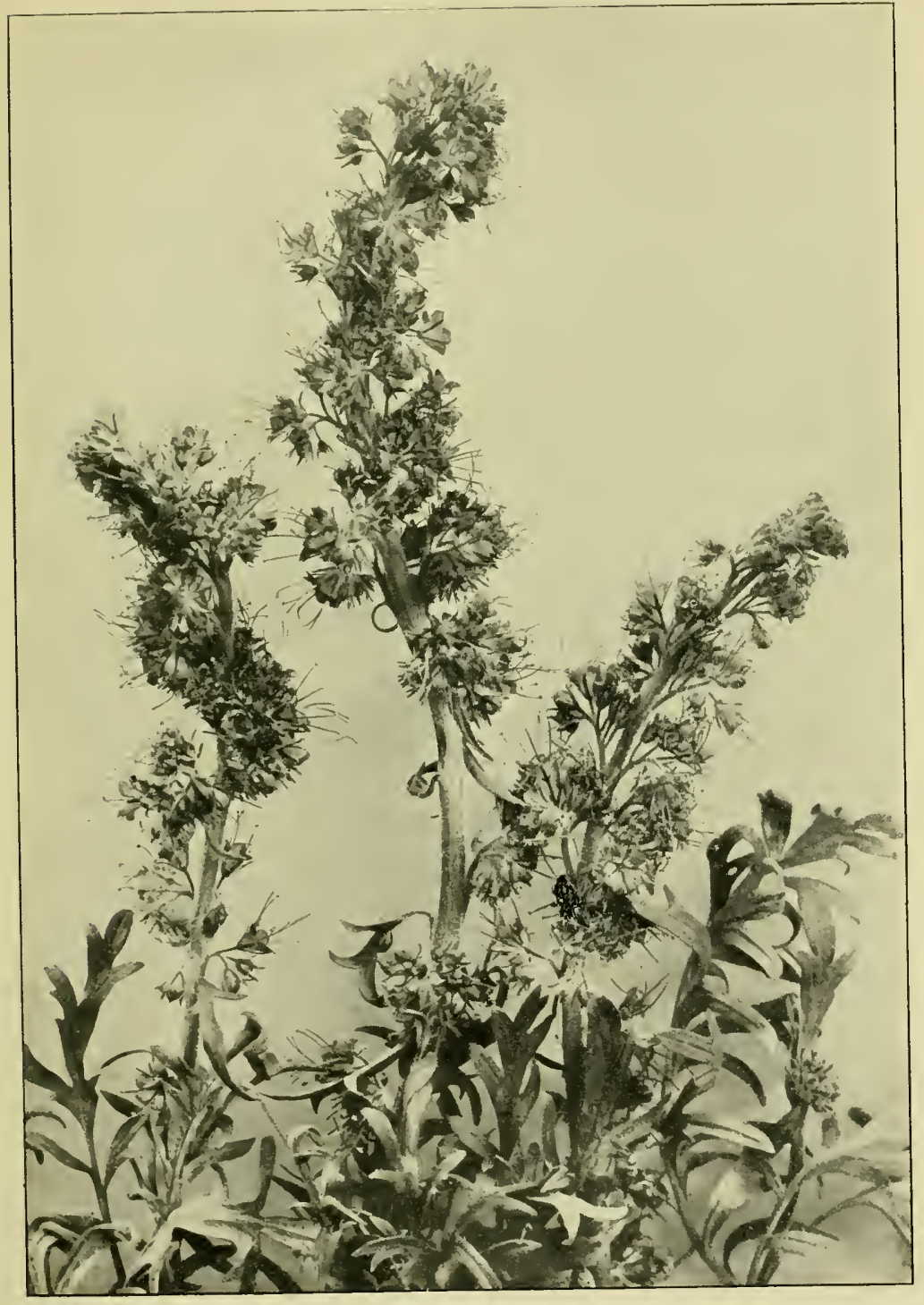

Mountain Phacelia

(Phacelia sericea) 

PLATE LXIX

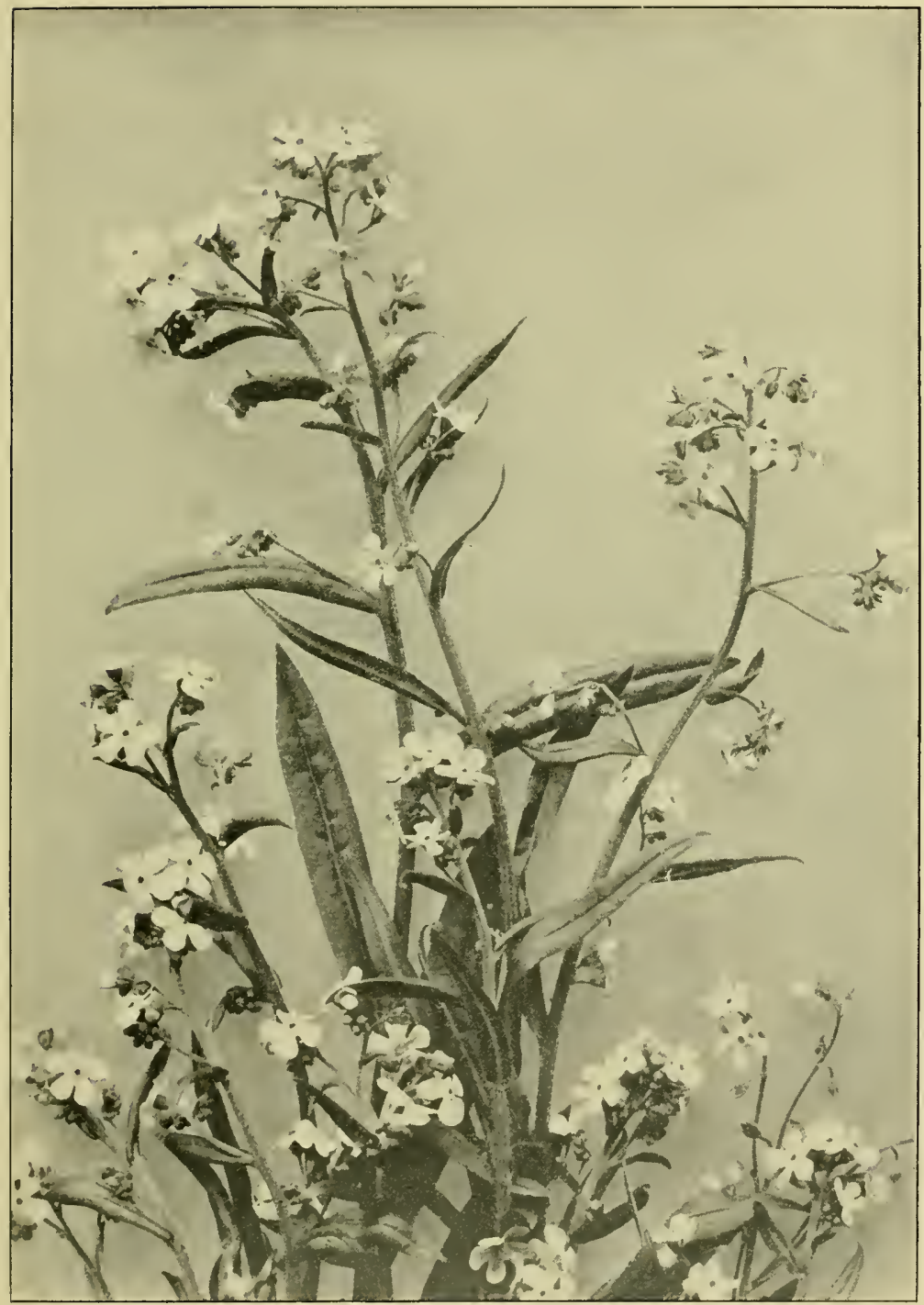

FALSE FORGET-ME-NOT

(Echinospermum floribundum) 

very tall under favourable circumstances, such as near water and on the open sunshiny slopes, and its flowers, blue as hearen itself, or very occasionally white, are funnel-form, the tube being very short and having its throat nearly closed by five flat lobes, which form a circular arching crest in the centre. The tiny stamens, and the style with its minute capitate stigma, are set inside this bright yellow circle, or "eye."

It matters little, after all, whether these flowers are False or True; they are beautiful to look upon, and very fragrant, as they hold their

"Festival

Of breaking bud and scented breath"

high up in some alpine meadow, where the air is fresh and wholesome and where the whole world seems full of wonderful possibilities.

E. Lappula, or Stickseed, has much smaller leaves and very tiny bright blue flowers, each individual blossom being little larger than a pin's head. These flowers grow in close leafybracted racemes, which are more or less one-sided, and when in fruit it bears innumerable tiny burs. It is not indigenous.

\section{TALL LUNGWORT}

\section{Mertensia paniculata. Borage Family}

Rough-pubescent. Stems: erect, branched above, the branches slender. Leaves: thin, pinnately veined, those of the stem ovate-lanceolate, acuminate; basal leaves ovate, rounded. Flowers. several-flowered in loose terminal panicles; calyx-lobes acute; corolla funnel-form, crested in the throat.

The Tall Lungwort grows from one to three feet high, and is one of the handsomest members of a family of coarse and hairy plants. It has very showy blue flowers, their tubes crested in the throat and the lobes only slightly spreading. These grow in loose terminal clusters.

Probably it is because there are so few really blue mountain wild flowers that we specially prize this striking plant. On 
every hand we see various shades of purple, mauve, violet, and heliotrope, - but very rarely of blue.

"Blue! 'T is the life of heaven, the domain

Of Cynthia, the wide palace of the sun, The tent of Hesperus, and all his train,

The bosomer of clouds, gold, gray, and

Blue! ' $T$ is the life of waters, ocean

And all its basal streams.

Blue! Gentle cousin of the forest green,

Married to green in all the sweetest flowers."

\section{TRUE FORGET-ME-NOT}

ITyosotis sylatica z'ar. alpestris. Borage Family:

Stems: erect, tufted. Leaves:- oblong, linear. Flowers: in dense racemes; calyx five-parted, hirsute; corolla salver-form, the throat with small blunt crests at the base of the rounded lobes.

This is the real True Forget-me-not. It grows from about fou to six inches high and is found only at high altitudes. Its tiny turquoise flowers are very fragrant. Unlike the prickly burs of the False species, the nutlets of the True Forget-me-not are quite smooth.

There are innumerable stories told concerning these blueeyed flowers, which are the emblems of undying love and are identified with our most romantic sentiments. One of the most charming legends about them rums thus :

"When to the flowers so beautiful

The Fatloer gave a name,

There came a little blue-eyed one

(All timidly it came).

And, standing at the Father's feet,

And gazing in His face,

It said, in low and trembling tones,

l'et wit's a gentle grace:

'Dear Lord, the name Thou gavest me,

Alas! I have forgot';

Kindly the liather looked Hin down

Ancl said, "Forget He not." 
PLATE LXX

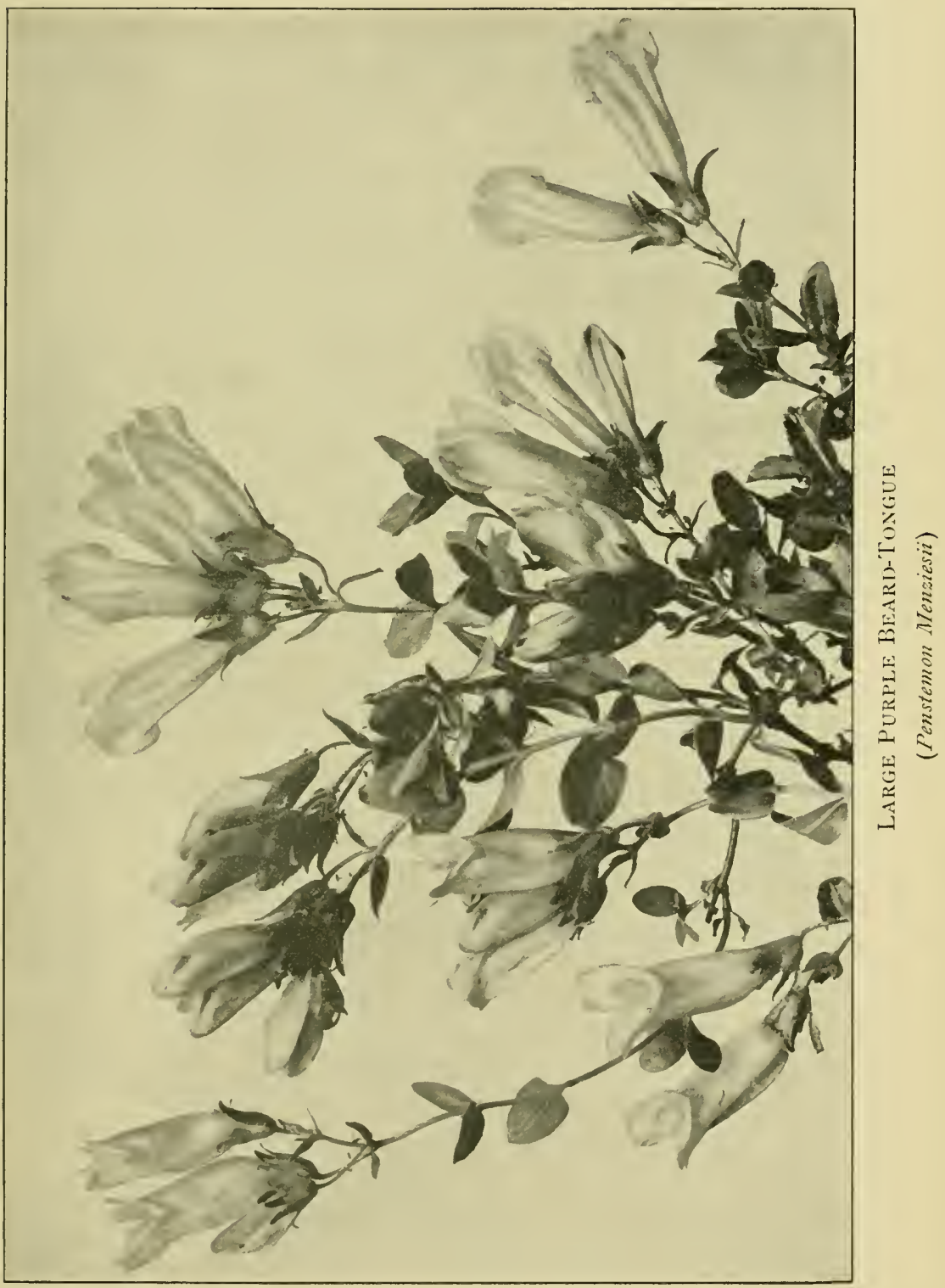





\section{SMALL-FLOWERED COLLINSIA}

\section{Collinsiu paraiflora. Figwort Family}

Stems: very slender and weak. Leaves: oblong or lanceolate, mostly obtuse at the apex and narrowed at the base, entire or sparingly toothed, the lower ones opposite, the upper ones in whorls. Flowers: on long pedicels: corolla variegated blue and white, the throat longer than the limb, which is two-lipped, the upper lip two-cleft, its lobes recurved, the lower lip larger and three-lobed.

A pretty, fragile, little plant, with numerous variegated blue and white blossoms. It grows thickly in moist places, selclom attaining more than eight inches in height. It is not unlike a very tiny Lobelia.

\section{LARGE PURPLE BEARD-TONGUE}

\section{Penstemon Menziesii. Figwort Family}

Low, densely matted, prostrate, with lateral leafy branches, which bear erect flowering shoots two to six inches high. Leaves: thick, long, obovate, dentate, the flowering stems bearing several pairs of orbicular leaf-like bracts. Flowers: calyx five-parted; corolla tubular, moderately bilabiate, the upper lip two-lobed, the lower lip three-lobed and bearded within.

These handsome purple and pinkish flowers are an inch or more in length and form large mats of brilliant colour upon the rocks at very high elevations. The plant grows prostrate upon the ground and has numerous short erect shoots, bearing the blossoms, which are tubular in shape and have two lips, the lower one being thickly bearded with soft white hairs. Penstemon comes from the Greek pente, "five," and stcmon, "a stamen," and refers to the large fifth sterile stamen, which is simply a filament without an anther and is densely hairy like the lower lip. It is to this pert little bearded tongue, which projects far beyond the other four fertile stamens, that the flower owes its common name. 
P. confortus atar. cerulco-purpurens, or Blue Beard-tongue, is very like $P$. confertus, or Yellow Beard-tongue, described in the Yellow to Orange Section.

Its flowers are bright blue or violet, and are usually set in two dense circles round the stem, though there is also a lowgrowing form of this species found in the mountains which has blue flowers growing in a simple terminal cluster.

\section{ALPINE SPEEDWELL}

leronica alpina. Figwort Family

Stems: crect, slender, usually simple. Leaves: oblong, ovate, sessile. mostly rounded at both ends, nearly entire. Flowers: in a short narrow raceme; corolla rotate, its tube very short, deeply four-lobed, the lower lobe the narrowest.

These small azure-blue blossoms win the love of many a traveller by reason of the fact that they are among the last flowers he sees growing in the crevices of the great moraines that fringe the glaciers, and are frequently the first ones to meet his eyes as he comes off the snowy ice-fields after making some arduous ascent.

"The little speedwell's darling blue"

renders it conspicuous, though its flowers are very small indeed, being clustered together at the tops of the stems. One marked peculiarity of the Speedwells is that the blossoms, which are cleft into four lobes, usually have the lower segment narrower than the rest. The Dutch call this plant "Honour and Praise," because it was once upon a time believed to contain valuable medicinal propertics. Many claimed it to be an excellent remedy for scrofula, and it was the great Linnecus himself who grouped it, together with all its relatives, uncler the family name of Scrophulariacea, or Figwort.

The erm lironica suggests far more beautiful associations. Here the plant is named after Saint Veronica, who in her 
PIATH LXXI

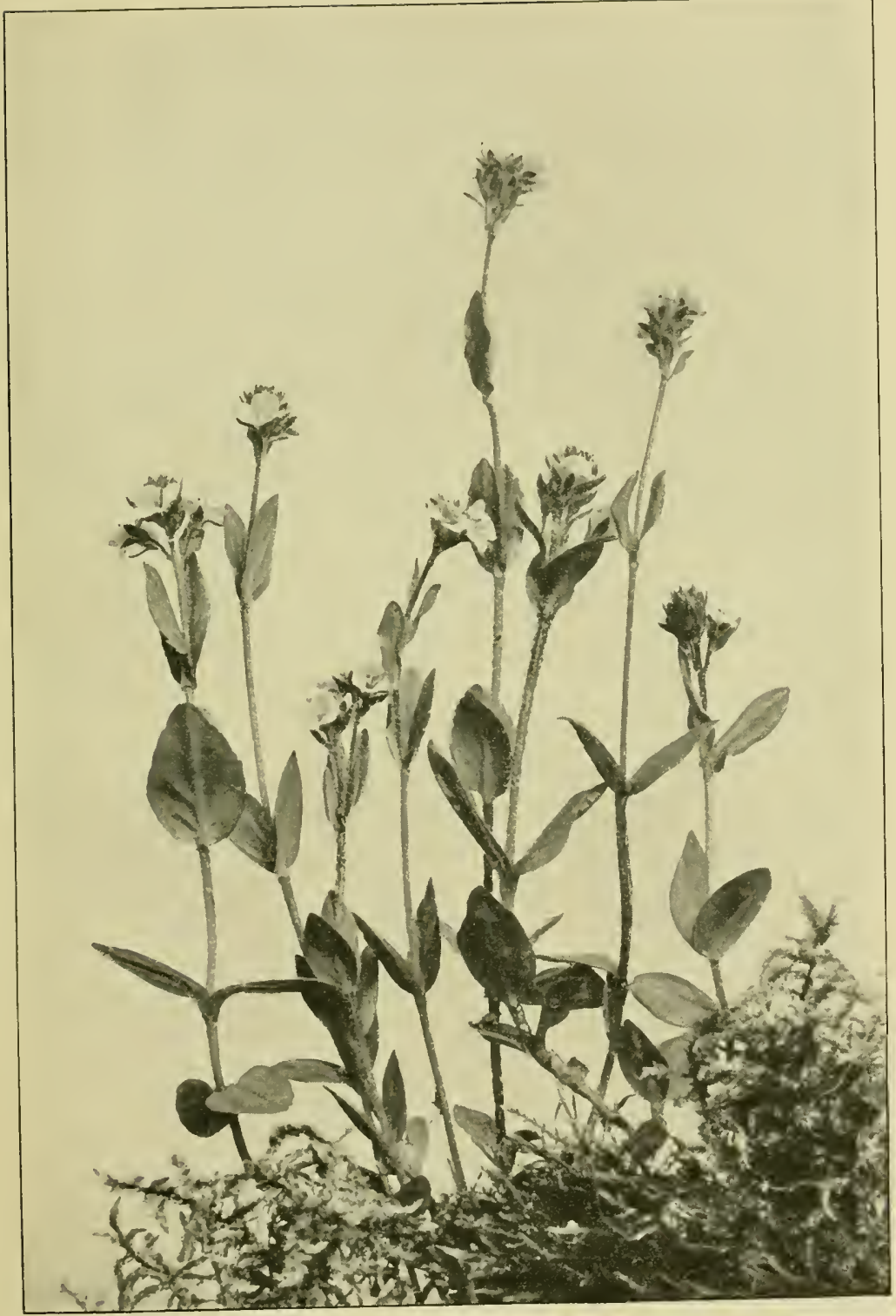

Alpine Speedivell

(Veronica alpina) 

turn was thus canonized because, according to an ancient tradition, she wiped the drops of agony from our Saviour's face when on His way to Calvary, and ever afterwards her kerchief bore the acra iconica, "the true likeness," of His sacred features.

$V$. serpyllifolia, or Thyme-leaved Speedwell, may be recognized by its decumbent branching stems; that is to say, the stems are curved near the base and lie partly on the ground, rooting where the joints touch the earth. Usually these stems grow in pairs and bear at their upper ends spikes of pale gray-blue blossoms striped with dark blue, the tiny flowers also growing at close intervals lower down on the stalks. The small oblong leaves grow in opposite pairs. Occasionally the flowers are white.

\section{BUTTERWORT}

Pinguicula anlgaris. Bladderwort Family

Stems: scape glabrous, tall. Leaves: from three to seven in a rosette at the base of the scape, entire, ovate, obtuse. Flowers: one-flowered; calyx five-parted; corolla bilabiate, the upper lip two-cleft, the lower one three-cleft, base of the corolla saccate and contracted into a nectariferous, acute, nearly straight spur.

At first sight the Butterwort looks like a lovely large purple violet, but a second glance reveals its rosette of very pale green leaves, with their involute margins, and the traveller at once recognizes the Pinguicula, its name being derived from the Latin pinguis, "fat," and referring to the horrible slimy greasy secretion with which its leaves are coated, and which renders them most repulsive to the touch.

The flowers are of a rich purple colour, and are two-lipped, the upper lip being cleft into two and the lower lip into three lobes. These lobes are delicately veined and the lower ones are covered with white hairs. The corolla terminates behind in a long straight spur. The Butterwort always grows near water, and usually in swamps or other very moist places. 


\section{WILD CANADA MINT}

\section{Mentha Canadensis. Mint Family}

Stems: erect, simple or brancined. Leaves: oblong, acute, sharply serrate. Flowers: all in short and dense, sessile, axillary glomerules; calyx oblong-campanulate, pubescent, five-toothed; corolla irregularly four-cleft.

The traveller has only to pick a spray of this plant to know its name, Mint, from Minthe, a lovely nymph whom the jealous Proserpine changed into a flower so that she might not win the admiration of Pluto, her lord and master. At least the memory of the ill-fated beauty is kept forever green and fragrant, for the leaves of the Mint contain numerous tiny glancls in which is secreted a volatile oil that has an excessively strong odour and flavour.

The flowers, which are either pinkish-purple or purplish-pink, and very occasionally white, grow in clense little clusters in the axils of the leaves.

\section{BRUNELLA}

\section{Brunella aulgaris. Mint Family}

Stems: numerous, slender, erect or procumbent, usually simple. Leaves: thin, ovate or oblong, obtuse, entire or crenate. Flowers: in dense, bracted, terminal and axillary spikes: calyx cylindraceous, with hirsute tecth; corolla-tube inflated, bilabiate, the upper lip entire, arched, the lower lip spreading, three-lobed.

The dense purple spilies of the Brunella, or Self-heal, are very common beside alpine streams and in the grassy meadows. This plant, which was called I'runclla by I innacus, is more significantly named Brunclla, because it is supposed to contain a remedy for dic Brämne, or the quinsy, and hence some ancient German botanist originally called it Bruncllen.

It is not an attractive flower, for its clongated spilies, covcred with dark reclelish bracts, have usually only a few scattered blossoms on them, and cren these are insignificant. The leaves grour in pairs up) the stems, and are frequently marked with reclelish patches. 


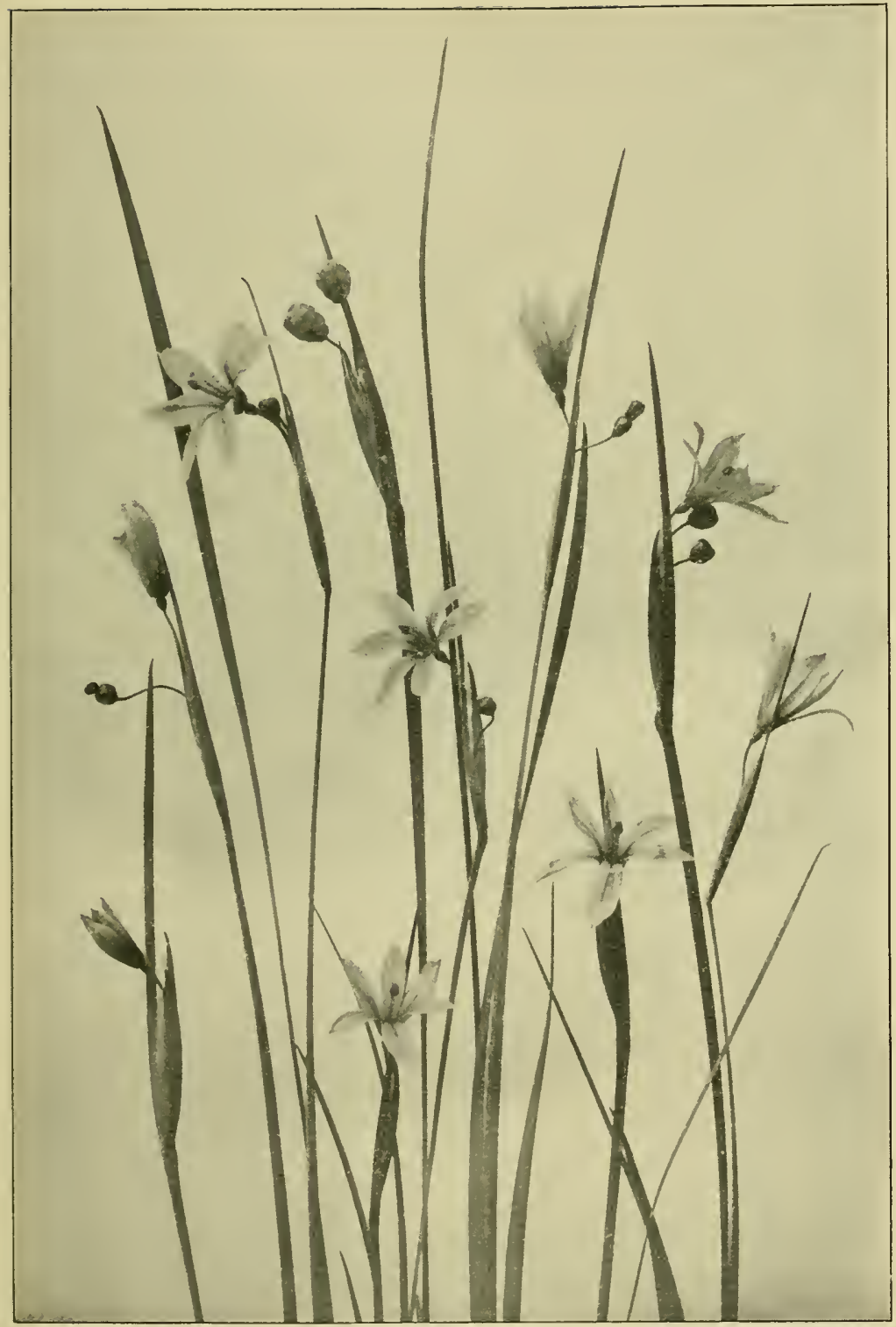

BLUE-EIED GRASS

(Sisyrinchium angustifolium) 



\section{HEDGE NETTLE}

Stachys palustris. Mint Family

Stems : erect, strict, simple, retrorse-hispid on the angles. Leaves: firm, lanceolate, oblong, almost sessile, acute at the apex, subcordate at the base, dentate. Flowers : in clusters, forming an elongated interrupted spike.

The Hedge Nettle has from six to ten reddish-purple flowers in each of the whorls that encircle its stem at intervals, and also bears a terminal cluster at the top. Stachys means "a spike," and refers to its elongated flower-spikes, while palustris signifies "growing in swamps," and is therefore peculiarly appropriate to this plant, which frequents very moist places. Probably it was called Hedge Nettle because the leaves resemble those of the true Nettle, but without the stinging properties of the latter. The Hedge Nettle is a very hairy plant, its leaves and stems being all covered with quantities of fine hairs.

\section{BLUE-EYED GRASS}

Sisyrinchium angustifolium. Iris Family

Stems: two-edged, slender, erect, rigid. Leaves: commonly all basal, linear, rigid, almost setaceous; bracts two, very unequal, erect, the lower one twice as long as the upper one. Flowers: six segments of the perianth spreading, aristulate.

"For the sun is no sooner risen with a burning heat,

But it withereth the grass,

And the flower thereof falleth,

And the grace of the fashion of it perisheth."

Was it of this tiny yet brilliant purple-blue flower that the Apostle Saint James wrote the above verse? Did he espy it, as he walked abroad, nestling amongst the sedges that fringed the streams? It is a very fragile little blossom, and as it resents being picked to the extent of immediately shrivelling up and clying, travellers had better be content to admire it where it flourishes in the moist low-lying meadows, and 
refrain from all attempts to gather it. This "little sister of the stately blue Flag" only blooms for a single clay, and each morning new bucls open to replace the fallen petals of yesterclay. Its flowers consist of six translucent purplish-blue segments, veined with a darker hue and tipped by a bristle from a notch. These grow on thread-like stalks between two very long narrow bracts, the lower one of which is usually twice as long as the upper one. In the centre of each blossom is a small patch of yellow, and the style, which is long and protrucling, is tipped by a conspicuous three-cleft stigma.

The name Blue-eyed Grass is most appropriate to this plant, for its leaves are certainly quite grass-like, being long and slender, and nearly all spring up from the densely tufted base, together with the stems, which latter are flattened on both sicles. The flowers are very like soft purplish-blue eyes with their dilated yellow "pupils," as they

"Gently gaze toward the sky,

Answering the azure blue on high."

Another poet sings thus of the Blue-eyed Grass :

"Blue-eyed grass in the meadow, And yarrow blooms on the hill, Cat-tails that rustle and whisper, And winds that are never still;

"Blue-eyed grass in the meadow,

A linnet's nest near by, Blackbirds carolling clearly

Somewhere between earth and sky.

" Blue-eyed grass in the meadow,

And the laden bee's low hum, Milkweeds all by the roadside,

To tell us summer is come." 


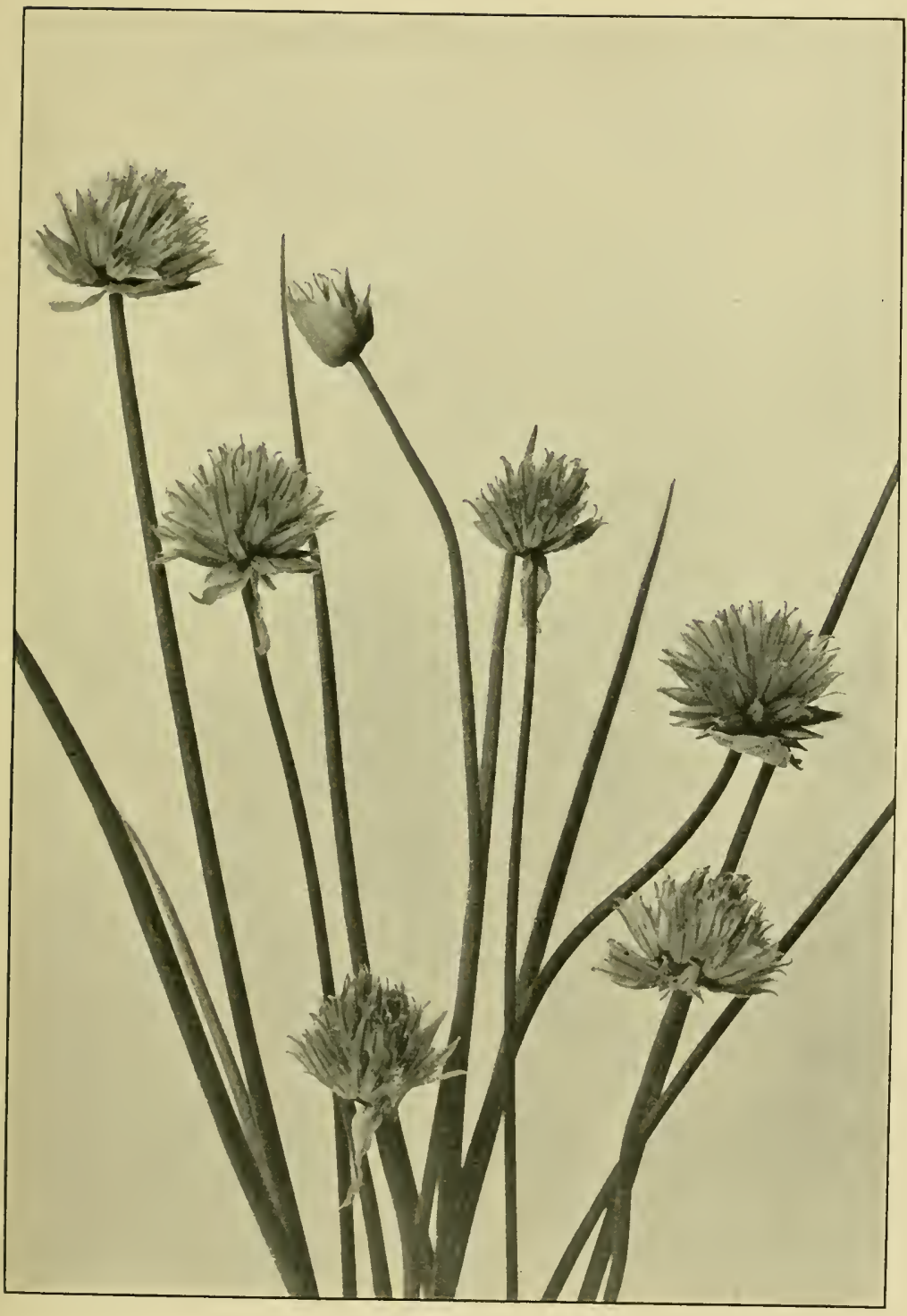

Purple Garlic

(Allium Schenoprasum) 



\section{PURPLE GARLIC}

\section{Allium Schanoprasum: Lily Family}

Bulbs narrowly ovoid, clustered. Stems: scape rather stout, bearing below the middle one or two elongated, linear, terete, hollow leaves; other leaves basal; bracts of the umbel two, broadly ovate. Flowers: in umbels, capitate; perianth of six equal, distinct, lanceolate, one-nerved segments.

This handsome Purple Garlic with its large dense flowerheads and long hollow leares is not at all common in the mountains, but is frequently cultivated in cottage-gardens for the sake of its beautifully coloured blossoms. Like all the Garlics, it has a very pungent odour. 

MOUNTAIN WILD FLOWERS

OF AMERICA

\author{
Section IV
}

YELLOW TO ORANGE FLOWERS 



\section{Section IV \\ YELLOIV TO ORANGE FLOIVERS}

\section{MEADOW BUTTERCUP}

\section{Ranunculus acris. Crowfoot Family}

Stems: erect, liairy, branched above, roots fibrous. Leaves: basal ones tufted, petioled, three-to-seven parted, the divisions sessile and cleft into numerous narrow acute lobes; upper leaves three-parted. Flowers: numerous; petals five, yellow, conspicuous. Not indigenous.

Every child knows and loves the bright yellow flowers of the common Buttercup. Every child has sung of

"Buttercups and daisies, And all the pretty flowers, Growing in the sunshine To tell of happy hours."

Yet the Ranunculus acris is the enemy of the farmer. Cattle will not eat of its acrid leaves, and even the hands of man are frequently scarred and blistered by the caustic juices contained in the stalks and leaves of this plant. Iligh up in the mountains, however, where the

\section{"Buds of yellow hue}

Do paint the meadows with delight,"

we welcome these brilliant Buttercups; there they can harm no one, but only please the eye with their finely dissected foliage and tall-stemmed golden flowers.

If you cut vertically through the middle of this Ranunculus, you will find that its receptacle is a long cone, from which the five green sepals, the five yellow petals, the numerous stamens, 
and the carpels all spread out successively. Care must be taken not to confuse the Ramunculi with the Potcntillas, which latter belong to the Rose Family and are also described in this Section, for the blossoms of the two plants somewhat resemble each other, though a close inspection and comparison of them, together with their stems and leaves, will always serve to plainly demonstrate at once the differences which exist between them. One point of variance which may be specially noted is that the Remunculus usually has simple lobed, or divided or dissected leaves, whereas the Potcntilla usually has compound leaves; that is to say, the Ranunculus has, in most cases, leaves that are much cut up and lobed, but the l'otcutilla, as a rule, has leaves formed of several entirely separate leaflets. This distinction is, however, not arbitrary, though it exists in the majority of cases. Also each petal of the Ramunculus has a tiny pit, or spot, covered by a scale, on the insicle of the claw, near the base. This spot is absent in all the Potcntillas. The Meadow Buttercup has fibrous roots.

R. Macounii, or Macoun's Buttercup, is an erect, very hairy plant, growing from one to two feet high, and has yellow flowers.

\section{SNOW BUTTERCUP}

Ranunculus Eschscholtzii. Crowfoot Family

Stems: ascending, one-to-three flowered. Leaves: roundish in outline, three-to-five parted, or deeply cleft, the obovate divisions lobed or incised. Flowers: yellow, the calyx covered with brownish hairs.

This alpine Buttercup grows at very high altitules, close to the snow and always near water. A cluster of much-rlivided leaves grows up from the base of the plant on long slencler stems, and half-way up the flower-stalk there is a circle of narrowly lobed leaves, and also, frequently, a single bud. The large yellowish calys, which is covered with brown hairs on the outsicle, gives the flower almost a double appearance. The head of the fruit is oblong. 


\section{CREEPING CROWFOOT}

Ranunculus Cymbalaria. Crowfoot Family

Stems : one-to-seven flowered. Leaves : broadly ovate, coarsely crenate, clustered at the base and joints of the long, filiform, rooting runners. Flowers : petals yellow, longer than the sepals. Fruit: the mature achenes striate-veined on the sides, apex blunt with a short oblique beak, heads oblong.

As its name denotes, this is a small creeping plant, having numerous runners which root at the joints, whence spring up little clusters of leaves. The flowers are yellow and very tiny.

R. aquatilis i'ar. stagnatilis, or Water Crowfoot, has tiny white and yellow flowers. The fine thread-like leaves are entirely submerged uncler the surface of the alpine lakes and pools, where the plant grows abundantly, while the broader three-lobed leaves float upon the face of the waters. These thread-like leaves are common to several kinds of aquatic plants, and such minute division enables them without a large expenditure of material to expose a large surface to the carbonic acid gas dissolved in the water.

R. reptans, or Creeping Spearwort, has small yellow flowers with from four to seven petals, trailing stems that root at the joints, and extremely narrow grass-like leaves. The flowers are borne in the axils of the prostrate creeping stems.

R. repens, or Yellow Crowfoot, is a hairy plant, which spreads by means of its runners and forms large patches upon the ground; it has leaves which are divided into three parts, each one of which is lobed and toothed. The flowerstalk is grooved, the sepals are widely spread, and the petals are half-erect. 


\section{MARSH-MARIGOLD}

Caltha palustris. Crowfoot Family

Stems: erect, one-to-two flowered, the lower flower subtended by a petaloid lanceolate bract. Leaves: roundish to oblong-cordate, longer than wide, irregularly crenate-toothed. Flowers: yellow; sepals petaloid, lanceolate, acute; petals none; stamens and pistils numerous.

This is a splendid-looking marsh plant, with large roundish glossy leaves of a deep bright green, and fine yellow blossoms that are tinged with purple on the outside. It resembles a large Buttercup. The name Marigold is a corruption of "Mary's gold," for this flower was dedicated to the Holy Virgin in the Middle Ages, a fact to which Shakespeare refers in $C_{y}$ mbline, when he causes the musicians to sing:

"Hark, hark! the lark at heaven's gate sings,

And Phœbus 'gins arise,

His steeds to water at those springs

On chalic'd flowers that lies;

And winking Mary-buds begin

'To ope their golden eyes."

The Marsh-marigold has no petals, but its five or more petaloid sepals do duty instead. The leaves of this extremely succulent plant are mostly heart-shaped at the base, and just below the flower is borne a petal-like long-shaped bract.

Oftimes amid the mountains you will see flat moist meadows literally ablaze with these showy shining blossoms, which tum the huge marshes into a veritable Field of the Cloth of Gold.

\section{YELLOW COLUMBINE}

Aquiligin flarescens. Crowfoot Family

Stems: smooth. Leaves: ternate; leaflets round-cordate, three-parted, the segments coarsely toothed. Flowers: yellow, pendulous; petals five, with short spreading lips, and produced backwards into long tubular spurs; sepals reflexed, longer than the spurs. 


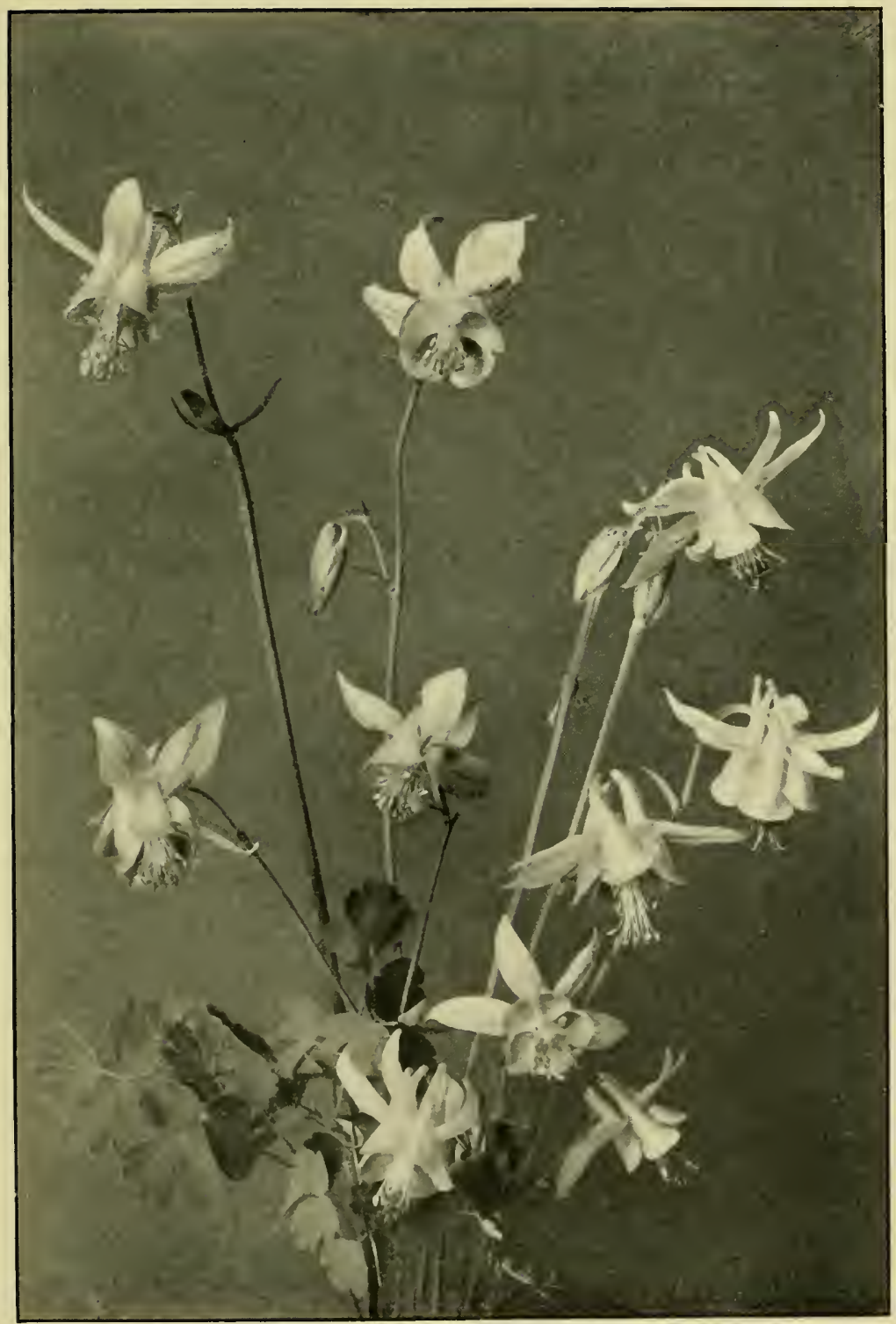

Yellow Columbine

(Aquileyia flavescens) 263 

This Columbine grows at great altitudes, and may be found amongst the rocks at a height of $\$ 000$ feet, where the soil is so light and sparse that there seems to be no foothold for any vegetation at all, much less for such tall and graceful plants as these Aquilegias, which stand from one to three feet high and bear abundant blossoms of palest purest yellow, pendent on their brittle stalks.

The foliage of the Yellow Columbine is much smaller and more delicate than that of $A$. formosa; but it is equally dark green above and pale green beneath. No prettier sight can be seen than clusters of these wild elfin flowers growing at the elge of some great barren cliff, their fragile loveliness shining against a sombre background of stony walls, from the height of whose overhanging ledges the drooping blossoms nod down at the traveller, as they sway and swing at the bidding of the breeze.

\section{YELLOW POND LILY}

Nuphar polysepalum. Water-lily Family

Leaves: all floating, eight to fourteen inches in diameter, broad-ovate, thick, deeply cordate, on stout half-cylindrical petioles. Flowers: two to five inches in diameter; sepals eight to twelve, unequal, concave and roundish; petals eleven to eighteen, dilated, truncate, shorter than the stamens. Fruit: globose, indehiscent.

This Pond Lily has numerous rounded concave sepals, which are of a deep orange-yellow colour inside and usually streaked and blotched with purple-red on the outside, and assume the functions of petals; for the real petals of this plant, though very numerous, are inconspicuous and rescmble the stamens, being thick, short, and fleshy.

The Yellow Pond Lily is not so beautiful as its cousin, the White Water-lily, yet the golden-hued mountain species is very fragrant; it has handsome floating foliage, and flowers which poets have not disclained to praise. 
Longfellow described Hiawatha's canoe as floating "Upon the river

Like a yellow leaf in autumn,

Like a yellow water-lily."

This Nuphar, whose name comes from the Greek word nouphur, signifying "Pond Lily," grows in still waters and slow streams, where, springing from thick, horizontal, deeply submerged rootstocks, the long stalks, which are flattened on the inner side and rounded on the outer side, uphold the gleaming floral cups. In many an alpine lake

"The bright Nymphaca loves to lave,

And spreads her golden orbs along the dimpling wave."

Nymphae signifies "a water-nymph," and the botanical family to which this Yellow Pond Lily belongs is called in the Latin Nymphaacea, or Water-lily Family.

\section{ARCTIC POPPY}

Papaver mudicaule. Poppy Family

Stems: scape erect, hirsute. Leaves: all basal, pinnately lobed or cleft, the lobes linear, acute. Flowers: solitary. Fruit: capsule obovoid, densely beset with erect bristly hairs.

This is quite an alpine-arctic plant and grows only on the highest summits. It has a flower varying in colour from yellow to reddish-orange, which grows on the top of a slender, very erect stalk, and is formed like a common l'oppy, but has only four petals. All the leaves grow at the base of the plant and are long-shaped and lobed.

\section{GOLDEN CORYDALIS}

Corydalis aurea arar. occidenalis. Fumitory Family

Commonly low and spreading. Leaves: finely dissected into oblongobovate segments. Flowers: in short spicate racemes; corolla tubular, irregular; petals four, one of the outer pair spurred at the base, the interior ones narrow, keeled on the back; spur half the length of the body of the corolla. Fruit: pods spreading. 
This plant generally grows low upon the ground, the very finely dissected foliage spreading out into large patches that are gemmed by the clusters of golden-yellow flowers, whose form at once suggests that of the WVild Bleeding-heart. When the ripe pods split open they disclose and scatter numerous bright shining seeds.

\section{TREACLE MUSTARD}

Erysimum paraiflorum. Mustard Family

Stems: erect, simple. Leaves: oblanceolate or linear, obtuse, entire, or dentate, the upper sessile, the lower slender-petioled. Flowers : pale yellow. Fruit: the siliques elongated, linear, four-angled, valves strongly keeled by a prominent mid-vein.

This common Treacle Mustard has very small pale yellow flowers and rather whitish leaves, which latter grow in a tuft at the base of the plant and also alternately all the way up the stiff erect stems. The flowers have four tiny green sepals and four yellow petals, which latter are cruciate, or set in the form of a cross. The Treacle Mustard belongs to the Crucifere, or Mustard Family, all of whose members have four cruciform petals.

\section{HEDGE MUSTARD}

Sisymbrium Hartwegianum. Mustard Family

Stems: slender. Leaves: pinnate ; leaflets lanceolate, obtuse and acutely toothed. Flowers: small, yellow. Fruit: the siliques erect on ascending pedicels, linear, elongated.

A coarse uninteresting plant, with pinnately cut leaves, the tiny leaflets being sharply toothed. The flowers are small and yellow and the pods long and narrow. 


\section{WILD MUSTARD}

Brassica Sinapistrum. Mustard Family

Stems: erect, hispid, with scattered stiff hairs. Leaves: oval, coarsely dentate, the basal ones pinnatifid. Flowers: showy, yellow, in elongated racemes. Fruit: the siliques elongated, sessile, tipped with a flattened conic beak. Not indigenous.

A handsome species bearing showy yellow flowers in terminal racemes, and having large oval leaves that are very coarsely toothed, rough to the touch, and conspicuously veined. The basal leaves are lobed. Like all the Mustards, it has four cruciform petals.

\section{GOLDEN WHITLOW-GRASS}

\section{Draba aurea. Mustard Family}

Stems: branching, pubescent, leafy to the inflorescence. Leaves: basal ones in tufts, spatulate, obtuse, slightly dentate; stem-leaves oblong, acute. Flowers: yellow, petals twice the length of the calyx, entire. Fruit: pods acute, at length slightly twisted.

A plant that resembles a Treacle Mustard, but is much smaller and has a rosulate tuft of leaves at the base. Tiny single leaves also grow up on the branching stems, and the little deep yellow flowers grow in close clusters.

D. alpina, or Alpine Whitlow-grass, is a tiny species found at extremely high altitudes. The leares are all basal and grow in a dense tuft, while the tiny clusters of little yellow flowers are set on the top of short naked stalks. The whole plant is hairy and scldom exceeds four inches in height.

\section{BLADDER-POD}

Physaria didymocarpa. Mustard Family

Stems: decumbent or ascencling, slender, simple. Leaves: spatulate, the basal ones obtuse, entire, narrowed into margined petioles; stemleaves nearly sessile, acute, much smaller. Flowers: yellow, in terminal racemes. Fruit: pods didymous, variable, with large, strongly inflated cavitics, emarginate at base and summit. 


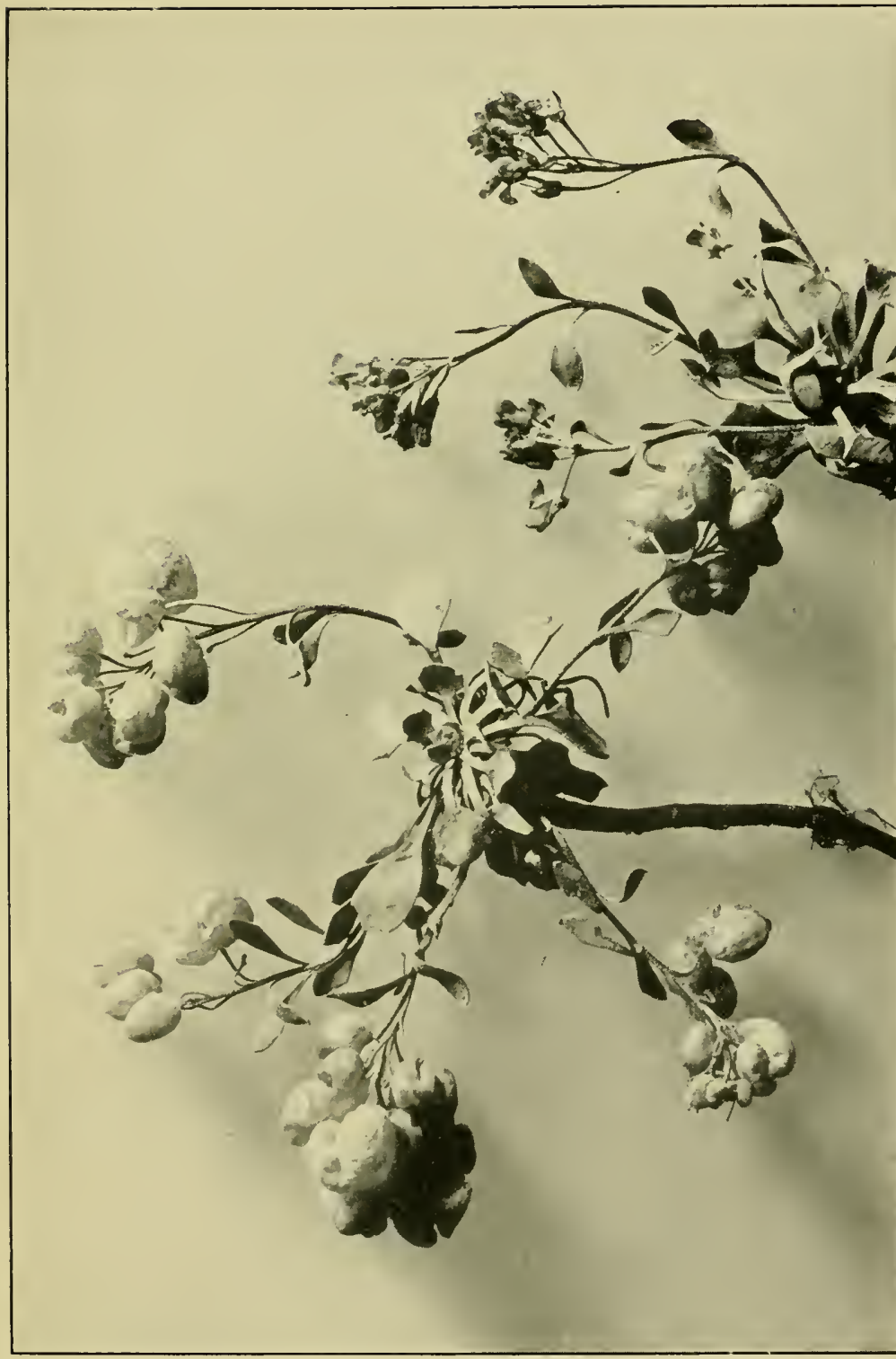

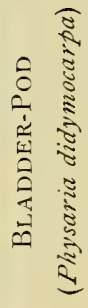



A most curious and interesting plant, which grows on high rocky slopes and forms patches upon the ground by means of its rosettes of pale green leaves and decumbent stems. The little yellow flowers are cruciform and inconspicuous, and grow in clusters at the ends of the long slender stalks which spring out from below the central rosettes of leaves, while an irregular circle of outer leaves grows beyond them again. It is the large inflated pods, of a delicate gray-green hue, which give this plant its common name and constitute its greatest attraction. They are really exquisitely quaint, and so unusual as to always attract the notice of the passing traveller. The leaves are spatulate and small. The name Physaria is derived from the Greek, signifying "bellows," and refers to the inflated fruit.

\section{YELLOW VIOLET}

Viola glabella. Violet Family

Stems: glabrous, slender, from a short fleshy horizontal rhizome. Leaves: radical ones on long petioles, the upper short-petioled, reniformcordate, crenately toothed. Flowers: bright yellow.

This is a small plant which blooms close to the ground, and is found chiefly at high altitudes.

"When beechen buds begin to swell,

And woods the bluebird's warble know,

The yellow violet's modest bell

Peeps from the last year's leaves below."

Its bright golden flowers are finely pencilled in the centre with black lines, and grow on short slender stalks amid a mass of small roundish leaves.

\section{YELLOW MELILOT}

\section{Melilotus officinalis. Pea Family}

Stems: ascending, one to four feet high, branching. Leaves: trifoliolate, petioled, rather distant; leaflets oblong, serrate, narrowed at the base, rounded at the apex. Flowers: in slender racemes; standard equalling the wings and keel. Not indigenous. 
The Yellow Melilot, or Sweet Clover, closely resembles the White Sweet Clover. It has spike-like racemes of tiny clustered flowers, which are very fragrant and extremely delicate both in shape and hue, and are borne on tall branching stems, which frequently attain a height of three or even four feet. The leaves are trifoliolate and smell very sweet when dried. They droop in a peculiar fashion at night-time, the upper leaflet and one side leaflet closing together, until the vertical surface of each comes in contact with that of the other, while the third leaflet is left alone, exposed to the chills and rains of the hours of darkness. The Yellow Melilot was introduced into this country from Europe.

\section{LOCO-WEED}

\section{Oxytropis Lamberti. Pea Family}

Silky-pubescent with appressed hairs, acaulescent, tufted. Leaves: odd-pinnate; leaflets linear, oblong, acute; peduncles longer than the leaves. Flowers : in large dense heads, or spikes. Fruit: pods incompletely two-celled, coriaceous, sessile, erect, ovoid-cylindric, long-acuminate.

A handsome rich cream-coloured or yellowish species of Orytropis, with soft whitish silky foliage and icry fine large flower-spikes. It usually grows on the dry alpire meadows.

\section{DRUMMOND'S DRYAS}

\section{Dryas Drummondii. Rose Family}

Low, tufted, herbaccous shrubs. Stems: woody at the base. Leaves: oval, crenate-dentate, green and glabrous above, white-canescent beneath. Flowers: yellow, solitary; calyx persistent, its tule concave, hirsute lobed; petals numerous; style elongated and plumose in fruit.

This insignificant little yellow flower, which meekly droops its head as if conscious of its lack of good looks, has the most lovely plumose seed-heads imaginable; and there are few pretticr sights in the mountains than that of some low-lying 


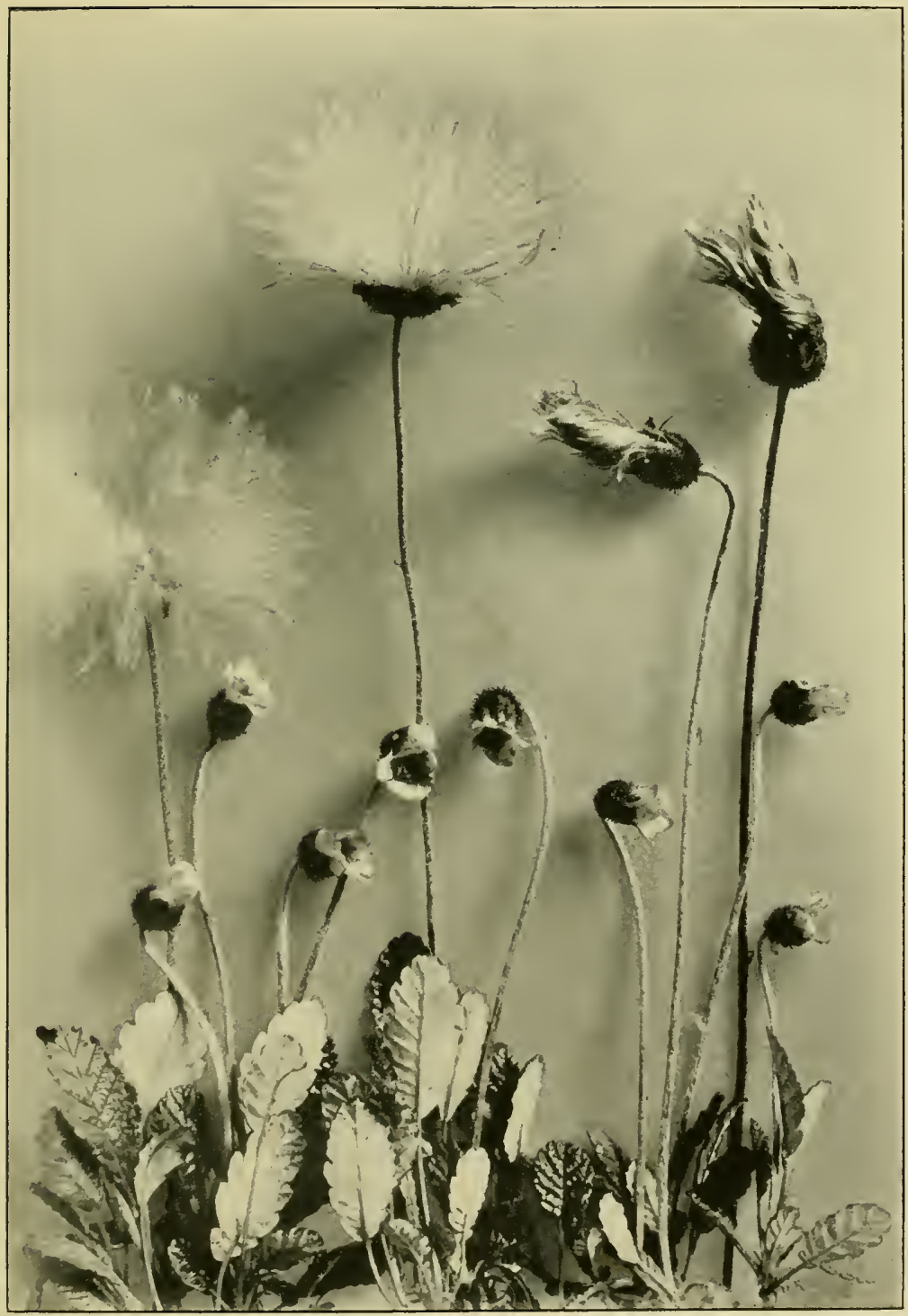

DRUMMOND'S DRYAS

(Dryas Drummondii) 

alpine meadow literally covered with these frail feathery tufts, rising up on their long, slender, wooly stems several inches above the prostrate foliage, half of which is curled over to show its silvery lining; for all the leaves of Drummond's Dryas are green and shining on the top and white and silky underneath. The flower consists of numerous small yellow petals enclosed in a short, hairy, green calyx; but as soon as these die and fall off, the stalk elongates and the seed-head quickly develops. This plant will grow in the poorest soil, and is most frequently found on arid gravel beds and in the gravelly battures of the alpine streams.

\section{YELLOW AVENS}

Geum strictum. Rose Family

Stems: ascending, pubescent, branched above. Leaves: basal ones lyrate-pinnate; leaflets five to seven, obovate, cuneate, dentate, with a few smaller ones interspersed, the terminal one largest; stem-leaves sessile, with three to five ovate acute segments. Flowers: several, terminal, of five petals.

This is a common plant, with bright yellow five-petalled flowers and large foliage. Each leaf is pinnately divided and has one big terminal segment and from four to six smaller leaflets, interspersed with some very tiny ones. The most noticeable feature is the fruit, which consists of a ball of seeds, each one terminating in an elongated barbed style.

G. macrophyllum, or Large-leaved Avens, is very like the prececting species, but it has much larger, coarser foliage. It also has bright yellow flowers and a bur-like head of seeds, each one of which terminates in the same slender, jointed, hooked style which is a distinguishing characteristic of this genus of plants.

Both the Yellow Avens and the Large-leaved Avens have lobed and toothed leaves and small clove-scented flowers. They are rough hairy plants and resemble weeds. 
Unattractive as is the coarse foliage of the Geums, yet their primrose-tinted blossoms gleam like jewels of pale gold amidst the dark green leaves, and these redeem the plants from utter ugliness.

\section{COMMON CINQUEFOIL}

\section{Potentilla dissecta. Rose Family}

Stems: decumbent or ascending. Leaves: pinnate; leaflets five to seven, the upper one incisely pinnatifid, dentate. Flowers: few, in an open cyme.

This is a low alpine plant, more or less silky and hairy, and has a yellow flower with a five-lobed calyx and five roundish petals. It resembles a miniature rose. The foliage consists of from five to seven toothed leaflets on each stem, the terminal leaflet being three-lobed at the apex.

There are several varieties of this species: $P$. dissecta war. glaucophylla has smooth green leaves; $P$. dissccta iar. multisecta has whitish silky foliage, each leaflet being long and narrow; and $P$. dissceta a'ar. pinnatisecta has more numerous leaflets and a one-flowered stem, which grows only about three inches high, the whole plant being smooth, with the exception of the hairy calyx and tufted apices of the leaves.

Many of the Cinquefoils (cinquc, "five" ; feuilles, "leaves") have five-parted leaves, hence their common name.

P. Auscrina, or Silver-weed, is a tufted plant, with elongated pinnate leaves composed of from seven to seventeen leaflets, which are sharply toothed, green, and smooth on the top), and very silky and whitish underneath. A characteristic feature of the Silver-weed is the minute pairs of leaflets which grow between the real leaflets, but are merely tiny pointed growths. The yellow flowers, which are typical of the whole genus and have five bracts, five sepals, five petals, and numerous stamens, grow on slender naked stalks that spring from the axils of the 
PLATE LXXVII

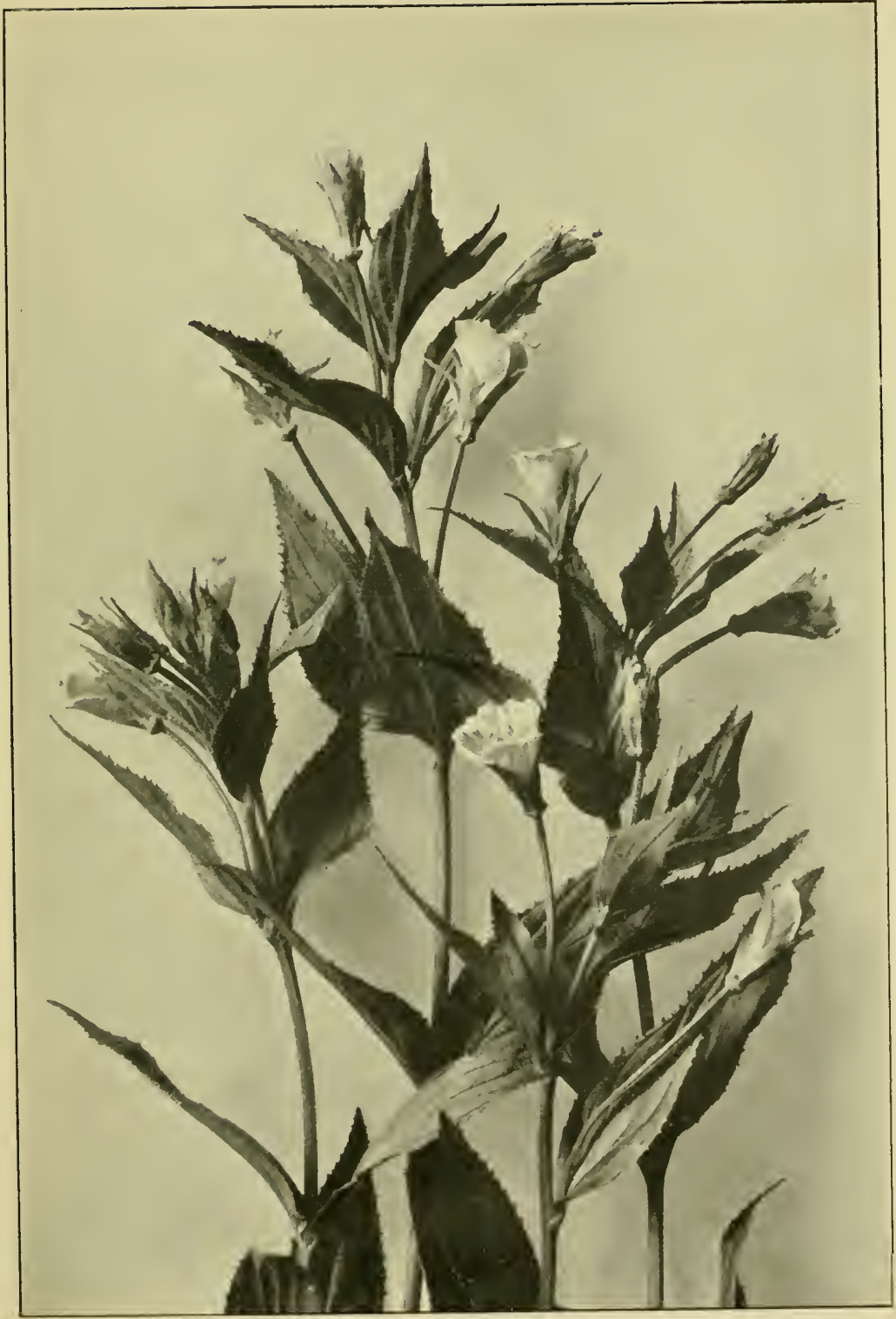

Yellow Willow-HeRB

(Epilobium luterm) 

leaves. The flowers are very pretty and velvety, and commonly grow in the moist meadows, for there

"The silver-weed with yellow flowers,

Half hidden by the leaf of gray,

Blooms on the bank of that clear brook

Whose music cheers my lonely way."

The Silver-weed creeps along the ground by means of slender many-jointed runners, and its stems are usually curved and winding. When the fruit ripens it consists of a head formed of several little achenes, or nutlets. The Potcntillas are very numerous in the mountain regions.

$P$. arguta, or Tall Cinquefoil, is a handsome plant, with coarse pinnate leaves, the terminal one being wedge-shaped and three-cleft at the top, and has small white flowers growing abundantly in loose clusters.

P. Norvegica, or Rough Cinquefoil, is a coarse weed-like plant, with leaves that are divided into three leaflets, and yellow flowers that grow in rather close leafy clusters.

P. Hippiana, or Woolly Cinquefoil, is a stout plant, with quantities of densely floccose and silky foliage. The leaflets are whitish and woolly on both sides, and deeply dentated. The flowers are bright yellow, and grow in graceful terminal clusters.

P. gracilis, or Small Cinquefoil, has very small leaves, heart-shaped in outline and composed of from three to seven leaflets, which are white and woolly beneath and green and silky on the top. The little flowers are yellow.

$P$. nivea, or Alpine Cinquefoil, grows at great altitudes and is found at 8500 feet. It is a tiny plant, with small trifoliate white and woolly leaves and wee terminal yellow flowers.

In studying the Potentillas it is wise to refer to the Ranunculi, also recorded in this Section, and note the close resemblance yet distinct variations which exist between the two genera. The clifferences between the foliage of the 
Potcutillas and that of the Ramunculi have already been referred to in the description of the latter plants, but it may be further noted here that the stamens of the Ranunculi are hypogynous, or borne at the base or below the ovary, while those of the Potentillas are perigynous, or borne on the perianth around the ovary.

\section{YELLOW SAXIFRAGE}

Saxifraga aizoides. Saxifrage Family

Stems: leafy. Leaves: alternate, linear, thick, fleshy, mucronatetipped, narrowed at the base, sessile, the margins sparingly ciliate. Flowers: several, corymbose; petals five, oblong, yellow, usually spotted with orange; calyx five-lobed, base of the capsule adnate to the calyx; stamens ten, inserted with the petals. Fruit: ovary two-celled, twolobed at the summit; styles short; stigmas capitate.

This Yellow Saxifrage grows among the wet rocks at very high altitudes. It has slender stems, adorned with alternate leaves, which are long and narrow and edged with a few fine hairs. The flowers grow ereet and open out very wide, their petals being usually spotted with orange. The ten stamens are conspicuous, and so is the large two-celled ovary, while the styles are short and tipped with roundish stigmas. This plant grows in dense tufted clusters from two to six inches high, and may be found in the most sun-forsaken crannies, where the icy breezes blow across the snow-ficlds.

\section{STONECROP}

Sedum stenopetalum. Orpine Family

Flowering branches erect. Leaves: alternate, crowded, but scarcely imbricated except on the sterile shoots, sessile, linear, entire. Flowers: in a three-to-seven forked cyme, compact; petals narrowly lanceolate, very acute, much exceding the calyx-lobes.

This plant is well named Sctum, from sedere "to sit," for it sits very happily, and in lowly fashion, upon the bleak 
bald hills at high altitudes. It is a most uncanny plant. The tiny, pale green, juicy leaves, crowded on the thick short stems, are, like human flesh, easily bruised; and each of the bright yellow flowers, which grow in dense clusters, has four or five narrow pointed petals. There are ten stamens, the alternate ones being attached to the petals. The five erect carpels are tipped with long conspicuous and divergent styles, crowned by fat stigmas.

The smooth clammy foliage of the Stonecrop reminds the traveller forcibly of the narrow gap which lies between the Animal and the Vegetable Kingloms, for the touch of its fleshy leaves is most repulsive, resembling that of some cold moist body. Fortunately, however, it is redeemed from being entirely objectionable by the twinkling little golden blossoms, which are as healthy and natural in their appearance as the foliage is the very reverse.

"Flower in the crannied wall,

I pluck you out of the crannies.

I hold you here, root and all, in my hand, Little flower - but if I could understand What you are, root and all, and all in all, I should know what God and man is."

"No deeper thought was ever uttered by poet," says John Fiske, in his beautiful work, Through Nature to God; "for in this world of plants, which, with its magician, chlorophyll, conjuring with sunbeams, is ccaselessly at work bringing life out of death - in this quiet vegetable world we may find the clementary principles of all life in almost visible operation."

Care must be taken not to confuse the Yellow Saxifrage with the Stonecrop. The former has tiny, thin, ordinary leaves, while the latter has leaves that are thick, fleshy, and very juicy. This peculiar foliage of the Stonecrop enables it to retain a quantity of moisture during the dry scason, an attribute which proves extremely useful, since it grows in crevices 
and crannies between the rocks, where the sparse dry soil affords little or no sustenance to the roots; hence its ability to imbibe and retain moisture through its leaves renders it fit to flourish on these sandy and stony slopes.

\section{YELLOW WILLOW-HERB}

\section{Epilobium luteum. Evening Primrose Family}

Stems: slender, nearly simple. Leaves: ovate, acute, sinuate-toothed, sessile. Flowers: from the axils of the upper somewhat crowded leaves; corolla funnel-form, rarely expanding, the lobes deeply notched; calyx short and deeply cleft.

The pale lemon-coloured flowers of the Yellow IVillow-herb grow in quantities near running water, or in the leep moist valleys where the rushes whisper in their husky throats and the moss weaves lace-like patterns to cover the ground. The plant stands from six inches to two feet high, and has large, conspicuously veined leaves, with wavy margins, which are very sharply toothed. The flowers are extremely pretty and delicate in hue; their four petals, folded in funnel-form, rarely expand, and are held up in green calyx-cups, which in their turn are cleft into four narrow slender divisions.

\section{EVENING PRIMROSE}

Enothera biennis. Evening Primrose Family

Stems: erect, stout, wand-like. Leaves: lanceolate, acute, narrowed and sessile at the base, repand-denticulate. Flowers: spicate, terminal, leafy-bracted; calyx-tube slender, the lobes linear, reflexed.

The Evening Primrose, whose bright yellow blossoms open in the twilight, somewhat resembles the Yellow IVillow-herb, whose paler flowers bloom at the bickling of the sunshine. Seen in the daytime, the Evening Primrose appears faded and uninteresting; but vicwed at night, its fragrant flowers are exceedingly attractive. The plant grows to an average height 


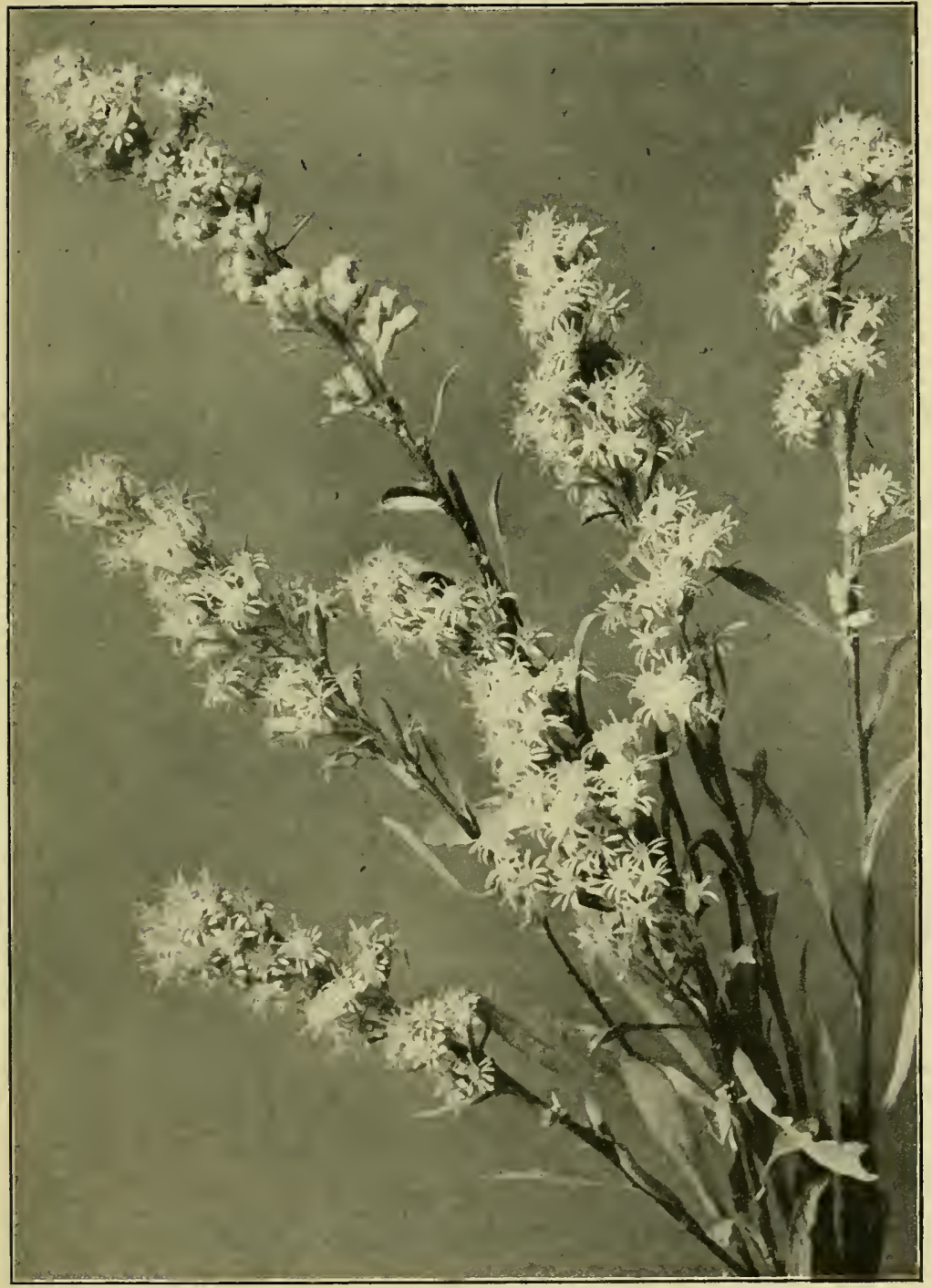

Field Golden-Rod

(Solidago decumbens) 

of three feet, and has alternate lance-shaped leaves and erect bucls. No sooner has the sun set than the buds begin to expand, the closely closed calyx suddenly bursting open with a loud pop, and then one by one the petals slowly unfold, until the whole sulphur-coloured flower is wide-blown and sends forth its sweet fragrance to scent the evening air.

"A tuft of evening primroses

O'er which the mind might hover till it dozes,

But that it's ever startled by the leap

Of buds into ripe flowers."

A single summer night suffices to consume the vitality and beauty of this flower, which at evening is fresh and fair and newly blown, and by noon looks faded and most dejected. It is strange how very fragrant and lovely are many of these "flowers that blow when the heat of the day is o'er," such, for instance, as the Night-blooming Jessamine, the Nightblooming Cereus, and the Night-blooming Cactus. The yellow petals of the Evening Primrose shine so luminously in the dusk that they easily attract the crepuscular moths, which fertilize the plants by carrying the abundant sticky pollen from one flower to another. The number four is conspicuous in this flower, which has four petals, a four-parted calyx, eight stamens, a four-celled ovary, and a four-cleft stigma. When the corolla fades, after its single night of revelry, it soon shrivels and drops off, and then the oblong capsule containing the seeds quickly matures.

\section{MEADOW PARSNIP}

\section{Thaspium cordatum. Parsley Family}

Stems: erect, branched. Leaves: upper stem-leaves compound, shortpetioled, ternate, the segments ovate, crenate-dentate; basal leaves longpetioled, sometimes undivided. Flowers: in umbels, eight-to-twelve rayed. Fruit: globose-ovoid. 
The bright shining green leaves of this Parsnip and its brilliant golden umbels of minute flowers combine to render it one of the many handsome plants that deck the damp alpine meadows. It has stout hollow stalks and very glossy foliage, the leaves being ternate, or arranged in threes, with broad, wavy-margined, sharply toothed leaflets. It has a most disagrecable odour.

\section{HAIRY GOLDEN ASTER}

Chrysopsis rillosa. Composite Family

Stems: villous. Leaves: alternate, oblong, obtuse, the upper ones sessile, the lower ones narrowed into a petiole, pale, canescent with appressed hairs. Flowers: heads few, terminating the short branches; rays oblong-linear; involucre hemispheric. Fruit: achenes obovate.

The yellow Aster is a very hairy plant, as denoted by its common name; it affects dry or sandy soil, and grows from six to eighteen inches high. The stems are simple, and near the summit short branches spread out, terminating in the solitary heads, which are composed of both tubular and radiate flowers. These bright golden flowers are enclosed in an involucre, which is formed of several series of tiny green bracts. The name Chry'sopsis, from chry'sos, "gold," and opsis, "aspect," is peculiarly applicable to these gay yellow blossoms, which glorify the dry waste places with their shining splendour.

\section{APLOPAPPUS}

\section{Aplopappus Brandegci. Composite Family}

Stems: from a tufted caudex, cinereous-pubescent, the involucre lanuginose-tomentose. Leaves: radical ones obovate or spatulate, contracted into a slender petiole; cauline ones few, sparse, small. Flowers: in heads of radiate and disk-flowers; rays eight to twelve, ligulate, pistillate, oblong; disk corollas perfect, dilated towards the summit, deeply fivetoothed. Fruit: achenes oblong-turbinate, densely silky villous.

This is a dwarf herbaceous plant, with a tuft of tiny green leaves at the base and one or two minute ones clinging to its 


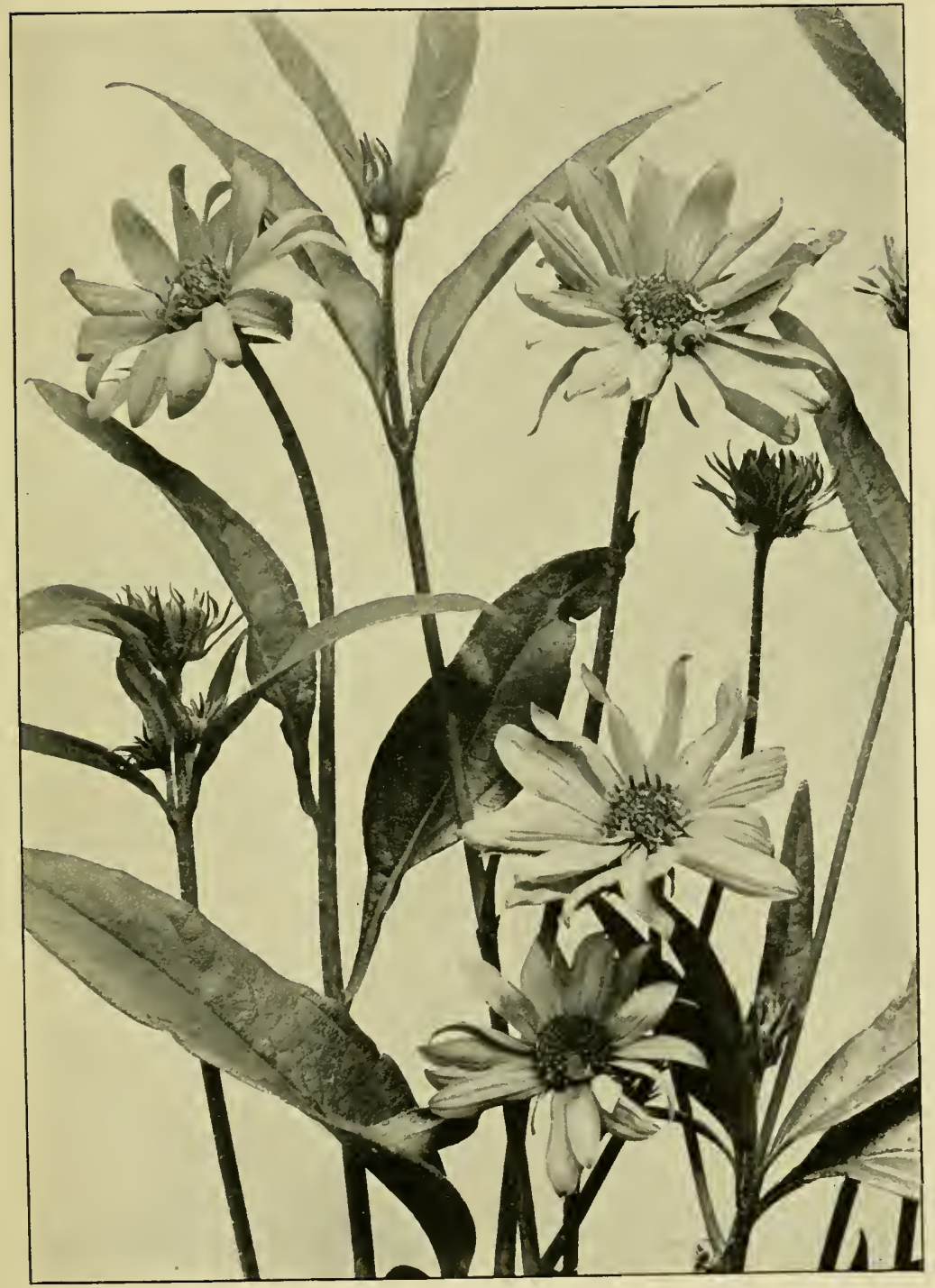

Giant Sunflower

(Helianthus giganteus) 

stems. It grows only from three to six inches high, and is found on lofty summits at 8000 and 9000 feet. The flowers resemble bright yellow daisies, and are rather ragged looking. At times, as the traveller stands upon the crest of some mountain top, where the earth seems very close to the sky of perfect blue, the gamboge blossoms of the Aplopappus, covering the ground with a torrent of bloom, seem to surge across the alpine plateaus in a succession of golden waves.

\section{CANADA GOLDEN-ROD}

\section{Solidago Canadensis. Composite Family}

Stems : stout, little branched, puberulent. Leaves: alternate, lanceolate, triple-nerved, acute at each end, the lower ones sharply serrate and petioled, the upper ones smaller, entire, sessile. Flowers: heads numerous, of both tubular and radiate flowers, on the spreading or recurving branches of the large and dense panicles; involucre campanulate, the bracts linear, imbricated in several series; rays in one series, pistillate; disk-flowers nearly all perfect ; corolla tubular, five-cleft.

The Golden-rods, many species of which grow abundantly in the mountain districts, are, together with the Asters, the handsomest of the late autumn flowers. Retaining the rich glow of the summer sun in their ripe yellow blossoms, they brighten the slopes and borcler the trails with a reflected glory. For the Golden-rod is at home in all kinds of places : by the dusty wayside and in the deep green forests; close to the borclers of the ice-born streams, and out in the open meadows, where the rays of light at noontide shine strongest. In each of these localities the tall wands, bearing their wealth of golden florets, wave gently to and fro, and never can we mistake the feathery plumes of the larger species, or the straight woody stems of the smaller ones, which are so thickly crowned by the tiny radiant flowers of this queen of Nature's garden.

It is a more difficult matter, however, to differentiate between the many species of Golden-rod that grow at high 
altitudes. The Canada Golden-rod is perhaps the easiest one to recognize, since it is the largest as well as the handsomest of its tribe, and has big branching panicles of close-clustered blossoms, very long, narrow, pointed leaves of a dull grayishgreen hue, and stout woody stems, which have a cottony appearance and attain an average height of three feet.

So numerous are the Golden-rods on this continent that it is possible to note only a few of the more conspicuous species which the traveller is likely to find and gather in the course of his wanderings amid the great hills, where

"Along the roadside, like the flowers of gold

That tawny Incas for their gardens wrought,

Heavy with sunshine droops the golden-rod."

S. dccumbcns, or Field Golden-rod, has tall, stiff, wand-like stems, which terminate in dense compact panicles of flowers, and sparse, long, narrow leaves, with even margins. It is very beautiful to walk across the alpine fields, where

"The golden-rod lights slowly

Its torch for the Autumn blaze,"

and where the other fall flowers unite to celebrate the passing of summer in a riotous splendour of scarlet, purple, and gold, and there revel in the sun-like smiles of these gay blossoms that illumine the landscape.

S. multiradiata iar. scopulomm, or Northern Golden-rod, is a coarser species with small loose clusters of rather large deep yellow flowers, which terminate the leafy downy stems.

"How deepening bright, like mounting flame, doth burn The golden-rod upon a thousand hills.

This is the Autumn's flower, and to my soul

A token fresh of beauty and of life, And life's supreme delight."

S. Missonricusis, or Mountain Golden-rod, has a perfectly smooth slender stem and short, broad, branching panicles of yellow flowers. The leaves are thick and lance-shaped, 
PLATE IXXX

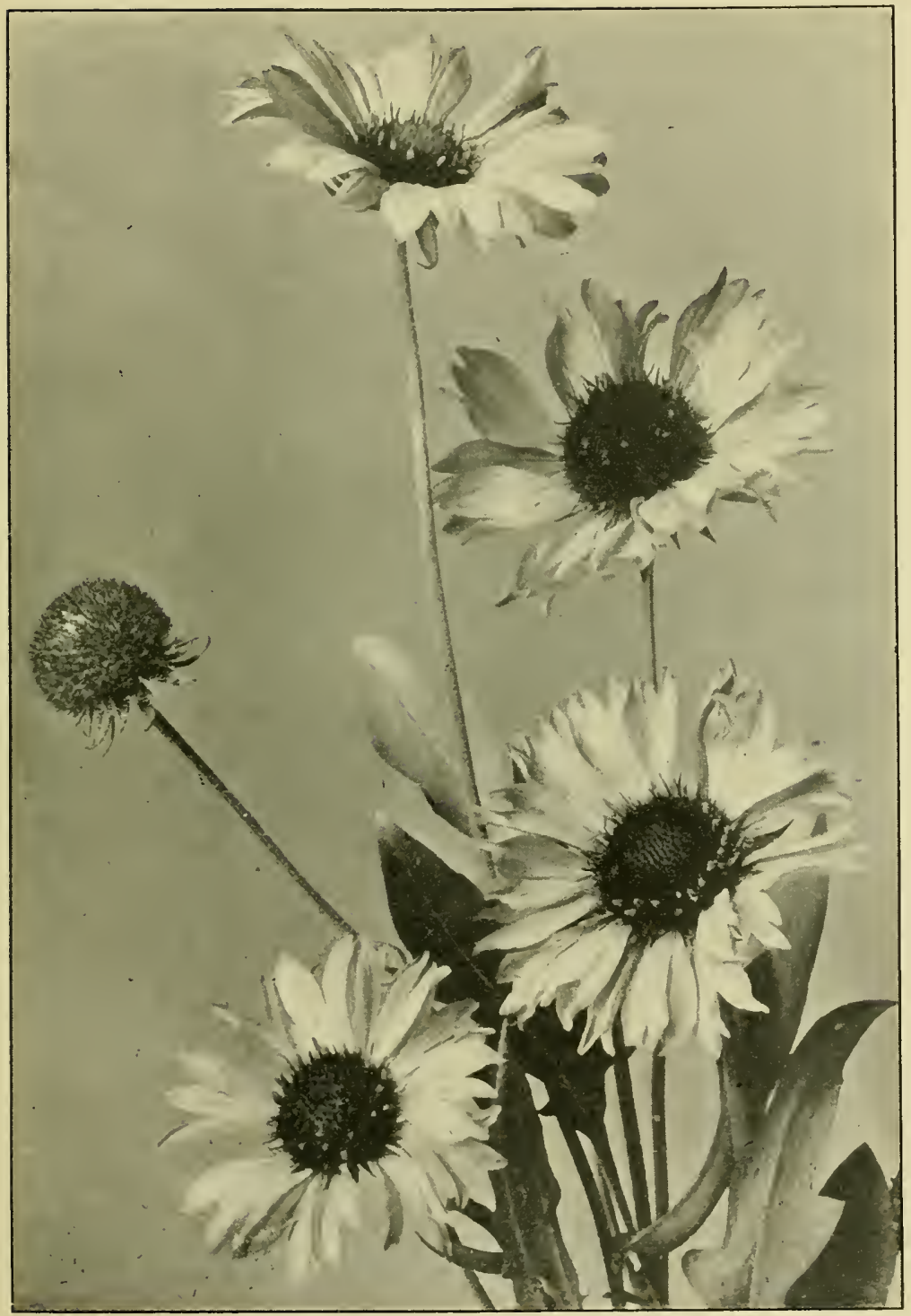

Great-Flowered Gaillardia

(Gaillardia aristata) 

with entire rough margins. It grows in dry soil and rears its clusters of golden bloom where the sunlight and shade interlace at the edge of the forests.

S. momoralis, or Gray Golden-rod, is so called on account of its gray-green cottony stems and leaves. The latter are lance-shaped and sharply toothed.

Thus we see that the Golden-rods grow everywhere, from the high hill-crests to the deep sweet valleys; that some species attain to a height of six feet under certain very favourable conditions, while others grow in dwarf alpine forms, wellnigh prostrate upon the ground; some are slender-stemmed, some have stout woody support; some bear big branching panicles of abundant bloom, while others again have but few blossoms closely clustered about their erect stalks. Yet in spite of all these many differences between the various species, the Golden-rods are quite unmistakable as a genus.

\section{GIANT SUNFLOWER}

Helianthus giganteus. Composite Family

Perennial by fleshy roots and creeping rootstocks. Stems: erect, hispid, branched near the summit. Leaves: lanceolate, very rough above, pubescent beneath, serrate, acuminate at the apex, narrowed at the base. Flowers : rays spreading, entire; disk-flowers perfect, fertile; corolla tubular, the tube short, the limb five-lobed; involucre hemispheric, hirsute.

What the cultivated Sunflower is to the other dwellers in old-fashioned gardens the wild Giant Sunflower is to the other dwellers in the woodlands. It is the gorgeous ornament and lord of the locality, one of the most conspicuous of all the many flowers that might fairly be designated by the term hclios, "the sun," and anthos, "a flower"; for the yellow Asters, Aplopappi, Gaillardias, Arnicas, and Ragworts are really all equally amenable to this title.

The Giant Sunflower has five large blossoms, composed of numerous bright yellow rays and a disk of perfect fertile florets. The leaves are lance-shaped and very rough to the touch. 
The Irish poet, Moore, referring to this flower as an emblem of constancy, has sung that

"The sunflower turns on her god when he sets

The same look which she turn'd when he rose."

But fact, unfortunately, refuses to corroborate his romantic fancy, for alas! the Helianthus does not turn its big golden flower-face from east to west to follow the course of the sun god, but, on the contrary, remains in the same position all day long.

In olden days, in Peru and Mexico, this flower occupied an important place both in the mythology and in the sculpture of the country, and also was employed as a mystic and sacred emblem by the inhabitants. The maidens who waited upon the sun god in the temple wore on their breasts representations of it executed in beaten gold, and it also was extensively cultivated in the gardens of the priests.

The ancient Greeks believed that the Helianthus was the incarnation of the nymph Clytic, who by reason of her great love for Apollo sat for nine days upon the ground intently gazing at the orb of day, until at length she became rooted to the earth and her face was transformed into the shining disk of the Sunflower.

All these legends tend, perhaps, to increase our interest in this handsome plant, whose brilliant-hued blossoms burn with a golden light in the mountain thickets and whose leaves make a waving of slight shadows across the land.

\section{GREAT-FLOWERED GAILLARDIA}

Gaillardia aristah. Composite Family

Stems : simple, or little branched, hirsute with jointed hairs. Leaves: firm, densely pubescent, the lower and basal ones petioled, oblong, laciniate, pinnatific or entire; upper leaves sessile, lanceolate, entire or dentate. Flowers: large-peduncled, heads of tubular and radiate flowers; rays cuneate, three-toothed; bracts of the involucre hirsute. 
PLATE IXXXI

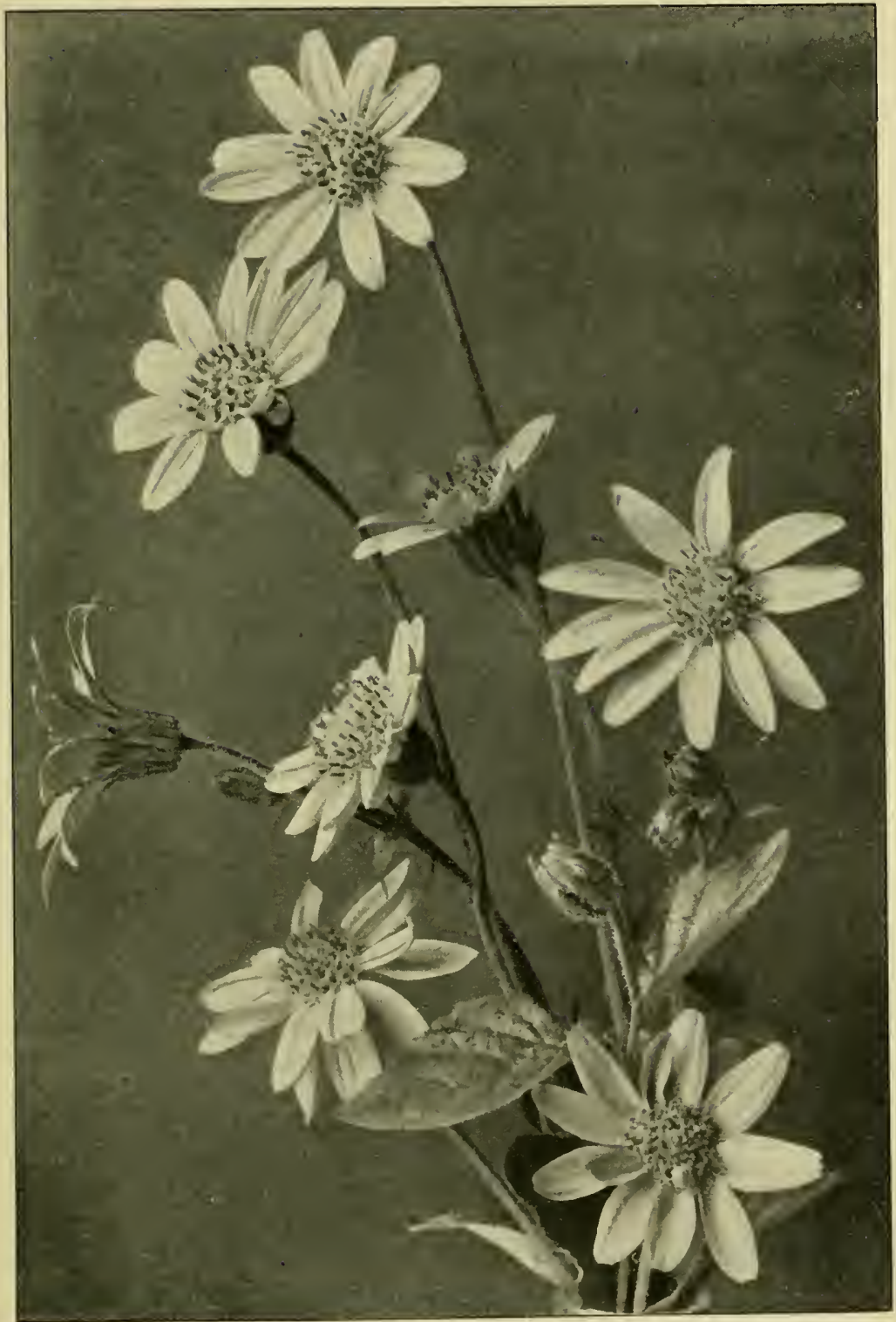

HEART-LEAF ARNiCA

(Arnica cordifolia) 

A gorgeous radiant blossom, with numerous bright golden rays, which are three-lobed at the apex, and having also a big, fringed, globose, reddish-brown centre, composed of many minute disk-flowers. The leaves are coarse, the larger ones being toothed half-way in the middle.

There are meadows in the mountains rendered more beautiful than any others by reason of these great showy Gaillardias.

Gaillardia Land! It lies far from the busy marts of men. Blue heavens above, and golden flowers about your feet, and all the -world full of a very abandon of colour. Here

"A thousand odours rise,

Breathed up from blossoms of a thousand dyes."

Ways of peace lead over the fields of rest, and whosoever wanders therein finds sweet food for dreams, and gladness all the way.

"Blue of a burning, boundless sky,

Gold of a boundless, splendid sod;

Prodigal noontide, far and nigh,

Blue and gold on the plains of God."

\section{HEART-LEAF ARNICA}

Arnica cordifolia. Composite Family

Stems : simple, or sparingly branched. Leaves: basal and lower ones ovate, obtuse and deeply cordate at the base, dentate; stem-leaves in pairs, ovate, sessile, small. Flowers : large long-peduncled heads of both tubular and radiate flowers; receptacle flat; rays slightly toothed at the apex.

This is the most common species of Arnica in the mountains, and is a handsome plant, standing from one to two feet high. It has pale green hairy leaves, which are markedly heart-shaped at the base, and many attractive blossoms composed of light golden rays, their deep yellow centres consisting of numerous disk-flowers. These blossoms, which are 
enclosed in a hairy involucre, formed by a series of narrow green bracts, grow singly or in pairs at the ends of the long slender stalks.

A. Chamissonis, or Chamisso's Arnica, is an extremely hairy species, usually found near water. The leaves are very long and narrow, and slightly toothed; the flowers are smaller than those of the Heart-leaf Arnica, and grow in clusters.

A. alpina, or Alpine Arnica, is a graceful delicately formed plant, with long, narrow, toothed leaves, and a single flower terminating each stem. It also frequently has two additional flowers springing from the axils of the upper leaves. Several pairs of leaves grow on the stems, and altogether the plant presents a more slender, refined appearance than do either of the two preceding species.

A. Parryi, or Parry's Arnica, bears a curious flower with no rays at all, but only a receptacle of disk-flowers enclosed in a green involucre. These flower-heads usually grow in threes at the summit of the three short-branched stems. They appear to have simply lost their rays in the early stage of decomposition, but such is not the case; they never had any.

\section{GOLDEN RAGWORT}

Senecio Balsamitce. Composite Family

Perennial, often tufted. Stems : slender, woolly at the base and in the axils of the lower leaves. Leaves: basal ones slender-petioled, oblong, very obtuse, crenate; stem-leaves pinnatifid, sessile, small. Flowers: in corymbose many-flowered heads of both tubular and ray-flowers.

This is a very common plant in the mountains. It has bright yellow flowers, which when in seed resemble small thistles. The rich loose clusters of the Golclen Ragrort grow to an average height of eighteen inches. The basal leaves have long stalks ant are rounded or oblong, with scalloped edges, while the stem-leaves are long, narrow, and slender, and very deeply cut. The name Scnecio is from sener, 


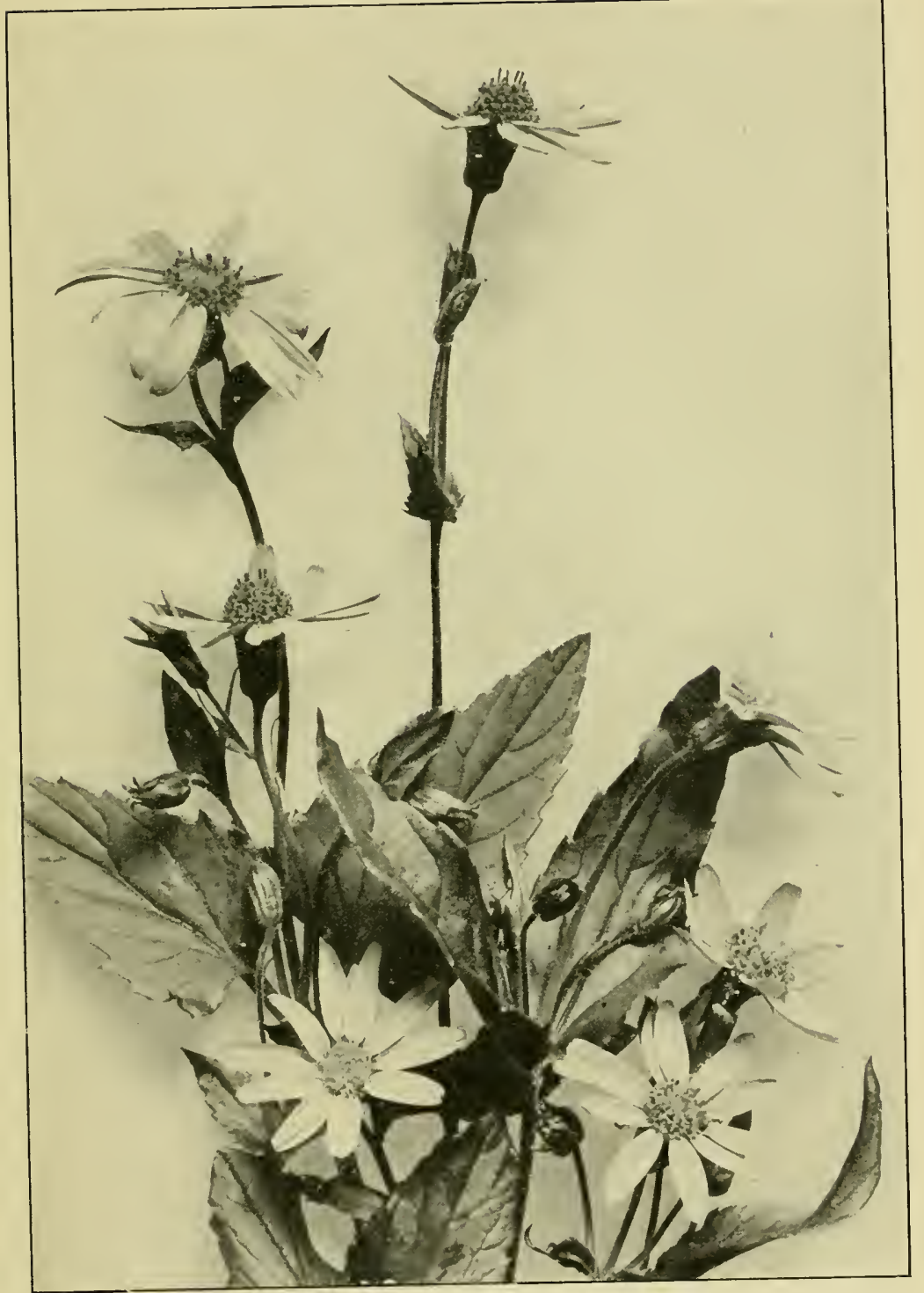

Alpine ARNiCA

(Arnica alpina) 

"an old man," and refers to the hoary-headed appearance of the plant when in seed, which is supposed to resemble the silky white hair of the patriarch.

Different species of Ragworts are quite numerous at high altitudes. They all have yellow flowers of various hues, shading from primrose to amber and orange; but the Golden Ragwort is the most abundant of them all. It is principally by their widely diverse foliage that the Senccios must be distinguished.

So bright and gay are these flowers, and all their fellows of golden mean, that we are compelled to wonder what caused Wordsworth, gentlest of poets and truest of Nature lovers, to write :

"Ill befall the yellow flowers, Children of the flaring hours."

What would the meadows be without the Dandelions, the Sunflowers, the Golden-rods, and the Arnicas? The land would lose much of its charm in Autumn did not these brilliant blossoms blazon back the beams of the declining sun.

S. triangularis, or Giant Ragwort, is a large coarse species with closely set flower-heads and numerous long triangular leaves, strongly veined, and sharply toothed at the edges.

S. canus, or Silvery Groundsel, is exactly described by its name, for it has white silky stems and leaves and pale yellow flowers. It is a small plant and grows on the dry open meadows. The basal leaves are oblong and have even margins, while the tiny stem-leaves are slightly toothed.

S. lugens, or Black-tipped Groundsel, is so called on account of the conspicuous little black tips distinguishing the bracts of its involucres, or green cups, which hold up the decp amber-coloured flowers. The basal leaves are very long and toothed; the upper leaves cling closely to the stem, and are small, bract-like, and smooth. 


\section{MANY-FLOWERED HAWKSBEARD}

Crepis clegans. Composite Family

Stems: many from a tap-root, diffusely branched. Leaves: entire, or nearly so, radical ones spatulate, cauline ones lanceolate to linear. Flowers: in small numerous-clustered heads. Fruit: achenes linear-fusiform, minutely scabrous on equal narrow ribs, attenuate into a short slender beak; pappus copious of very slender white bristles.

The Hawksbeards are all yellow, and their rays are squared and finely toothed at the tips, a characteristic which enables the traveller to at once clistinguish them from the Arnicas, to which they bear a strong resemblance.

The IIawksbeards are not very pretty or very interesting flowers, yet they contribute their share of golden strands to Nature's summer carpet.

C. nana, or Alpine Hawksbeard, is a small alpine species that grows at an altitucle of $\$ 000$ feet, on barren rocky ground. It is a tiny plant, forming tufts and bearing many clusters of small flowers.

C. muncinata, or Naked-stemmed Iawksbeard, has a cluster of long-shaped leaves at the base, and slim, almost leafless stems, terminating in single yellow flowers. It grows in moist soil.

\section{HAIRY HAWKWEED}

Hicracium Scouleri. Composite Fanily

Pubescent with long crisp hairs, pale green. Stems: one to two feet high, very leafy. Leaves : lanceolate, sessile. Flowers : in a loose irregular panicle; involucral bracts imbricated in two or three series; rays truncate, five-toothed at the apex.

A lovely plant! The pale green stems, leaves, and buds, thickly clothed with fine silvery hairs, and the brilliant golden flowers form an expuisite contrast, delighting the eye of the traveller. 'This Hawkweel is comparatively rare in the mountains. 


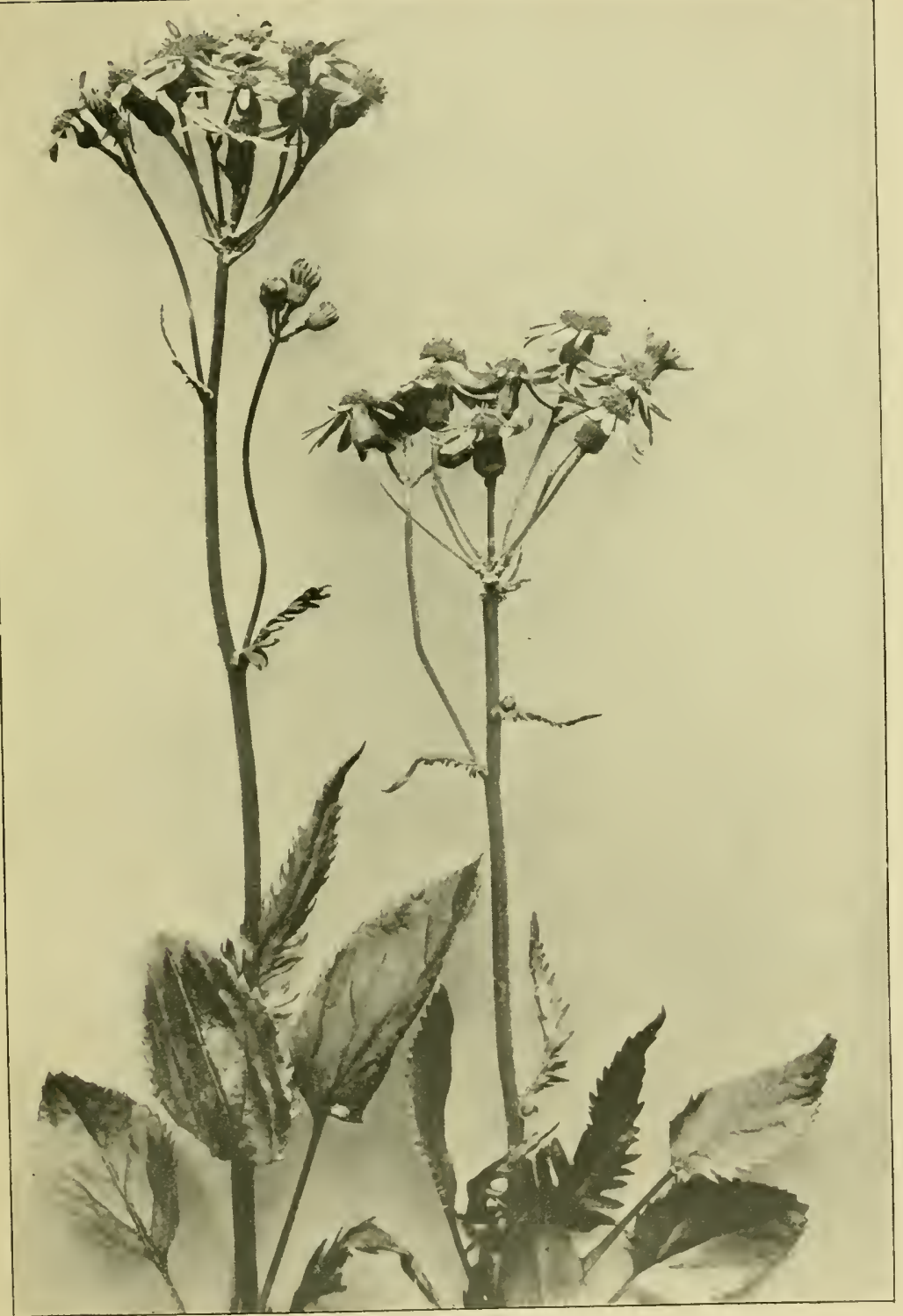

GOLDEN RAgwort

(Sencio Balsamite) 

H. gracile, or Small Hawkweed, has tiny yellow or white flowers borne at the end of the long, slender, branching stems. They resemble miniature Dandelions and are very abundant. Like the Hawksbeards, the rays of the Hawkweeds are truncate, or cut off squarely at the ends, and finely toothed.

\section{LARGE-FLOWERED FALSE DANDELION}

Troximon glaucum. Composite Family

Stems: scape naked, slender, pubescent. Leaves: all basal, linear, lanceolate, crenulate, acuminate at the apex. Flowers: heads solitary, yellow; rays truncate, five-toothed.

A flower very like a real Dandelion, but with totally different foliage. The False Dandelion may always be distinguished by its long ribbon-like leaves, which grow up from the base of the plant and have slightly wavy margins.

T. aurantiacum, or Copper False Dandelion, has deep orange or copper-coloured flowers, or very occasionally purplish flowers.

\section{COMMON DANDELION}

Taraxacum officinale var: lividum. Composite Family

Scapes and leaves from the crown of a thick vertical root. Leaves: lanceolate in outline, and from irregularly dentate to runcinate-pinnatifid. Flowers: in solitary heads at the summit of the hollow scapes; rays numerous; involucre a single series of nearly equal narrow bracts, and several calyculate ones, the outer reflexed, all acute.

"Common" as this Dandelion is named, and common as it is in all the mountain regions, yet it is far from being an ingly or even an uninteresting plant. On the contrary, its gorgeous golden blossoms render it extremely attractive. These blossoms consist of from one to two hundred strapshaped rays, their blunt tips notched into five teeth, which remind us that each ray-flower was once composed of five petals. The leaves are boldly cut into jagged lobes (supposed to resemble the teeth of a lion, hence the common 
name Dandelion, derived from the French Dent-dc-lion), and these lobes are again cut into secondary points.

As the Dandelion grows old the rays fall off, and it bends downwards until the seed matures; then, elevating its head once more, it expands into a beautiful, snow-ivhite, airy scedball, whose plumes blow away at the slightest puff and float off to find a new resting-place.

T. rupestre, or Alpine Dandelion, is a tiny slender plant with finely cut leaves and small flowers, which seldom grows more than four or five inches high. From the lowlands to the highest levels this

"Dear common flower that grows beside the way, Fringing the dusty road with harmless gold,"

is to be found.

\section{SOW THISTLE}

Sonchus areensis. Composite Family

Perennial by deep roots and creeping rootstocks. Stems : leafy below, paniculately branched and nearly naked above. Leaves: lower and hasal runcinate-pinnatificl, spinulose-dentate. Flowers: heads several, corymbose-paniculate, bright yellow, very showy. Fruit: achenes oblong, compressed, with about ten rugose longitudinal ribs. Not indigenous.

Every traveller will easily recognize this common Sow Thistle, with its yellow or yellowish flowers and its very prickly leaves. Sometimes it is called Milk Thistle, on account of the milky juices contained in the stems. I.ike many of the members of the great family of Composites, the Sow 'Thistle has an involucre of green bracts, a flat naked receptacle, and numerous strap-shaped rays, which are truncate and finely toothed. It is a coarse showy weed, and opens its flowers early in the day, closing them again soon after noon. 


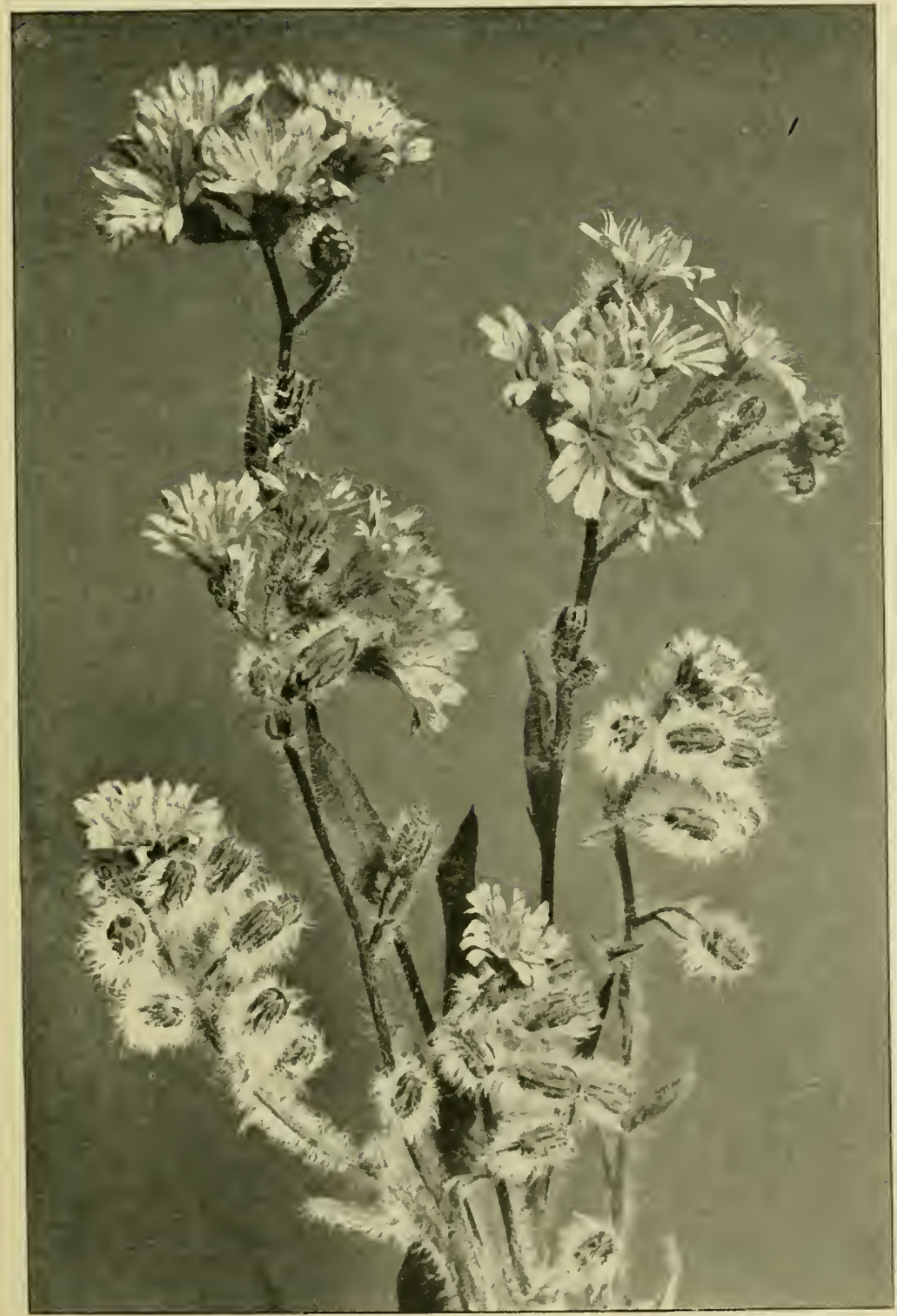

HAIRY HAWKWEED

(Hieracium Scouleri) 



\section{NARROW-LEAVED PUCCOON}

Lithospermum angustifolium. Borage Family

Stems : branched, erect or ascending. Leaves: linear, sessile, acute. Flowers : of two kinds, in terminal leafy racemes; corolla of the earlier ones salver-form, bright yellow, five-lobed, the lobes erose-denticulate, the throat crested; later flowers much smaller and pale yellow, cleistogamous, abundantly fertile, their pedicels recurved in fruit. Fruit: nutlets white, smooth, shining, ovoid, more or less pitted, keeled on the inner side.

The French call this Puccoon Plante aux Perles, because of the hard stony seeds that mature in the calyx, and which, though at first soft and green, gradually become hard, white, and shining. It is on account of these nutlets that the plant is named from the Greek lithos, "a stone," and sperm, "a seed." The flowers are a pretty lemon colour, the earlier ones being of a much deeper shade and larger in size than those which appear later in the summer. They grow in close leafy clusters, and have a long, salver-form, five-cleft corolla. The stems and leaves are quite downy. This Puccoon grows in small tufts or mats, from six to ten inches high, and is usually found on the dry open lands, where its

"Leaves and branches, crossed and linked, Cling like children and embrace."

\section{YELLOW BEARD-TONGUE}

\section{Penstemon confertus. Figwort Family}

Stems: slender. Leaves: lower ones lanceolate, attenuate below to narrow petioles, mostly entire, the cauline sessile by a broad base. Flowers: thyrsus spiciform, interrupted, dense, many-flowered clusters; corolla very narrow, lower lip conspicuously bearded within.

The Yellow Beard-tongue grows high up on the mountains. The flowers, which vary in hue from yellow to cream colour, are set in several dense clusters round about the stem, encircling it at intervals. For further information regarding the Penstemons see page 243 in the Blue to Purple Section. 


\section{YELLOW MONKEY-FLOWER}

\section{Mimulus Langsdorfii. Figwort Family}

Stems: erect. Leaves: ovate, sessile, denticulate. Flowers: terminal; calyx ventricose-campanulate; corolla-tube cylindric, its limb bilabiate, the upper lip erect, two-lobed, the lower lip spreading, three-lobed.

A small plant bearing abnormally large quaint flowers, bright yellow in colour and usually spotted with brownishred inside the corolla. The lower three-cleft lip is heavily bearded within by soft fine hairs, and so tiny are the little roundish leaves, and so slim the short stems, that the big bright blossoms appear rather top-heavy for so small a plant. Not actually growing in the water, but rather on those low marshy islands so frequently set in the middle of the alpine streams, you will find myriads of these Yellow Monkey-flowers nestling amid the mosses and reeds which spring up so luxuriantly between the stones by the river's brink.

\section{YELLOW ORTHOCARPUS}

\section{Orthocarpus luteus. Figwort Family}

Stems : strict, erect, branched above, densely leafy. Leaves : ascending, linear, entire or sometimes three-cleft, sessile, long-acuminate; bracts of the dense spike lanceolate. Flowers: in clense spikes, yellow; calyx tubular, with acute teeth; corolla-tube slender, the limb two-lipped, the upper lip ovate, obtuse, the lower lip saccate, three-toothed.

An uninteresting member of the numerous Figwort Family. It has very dense, slender, erect spikes, covered with tiny leaves and bracts and numerous bright yellow flowers. These flowers have a single upper lip and a three-toothed lower lip. The Yellow Orthocarpus usually grows in dry soil. 


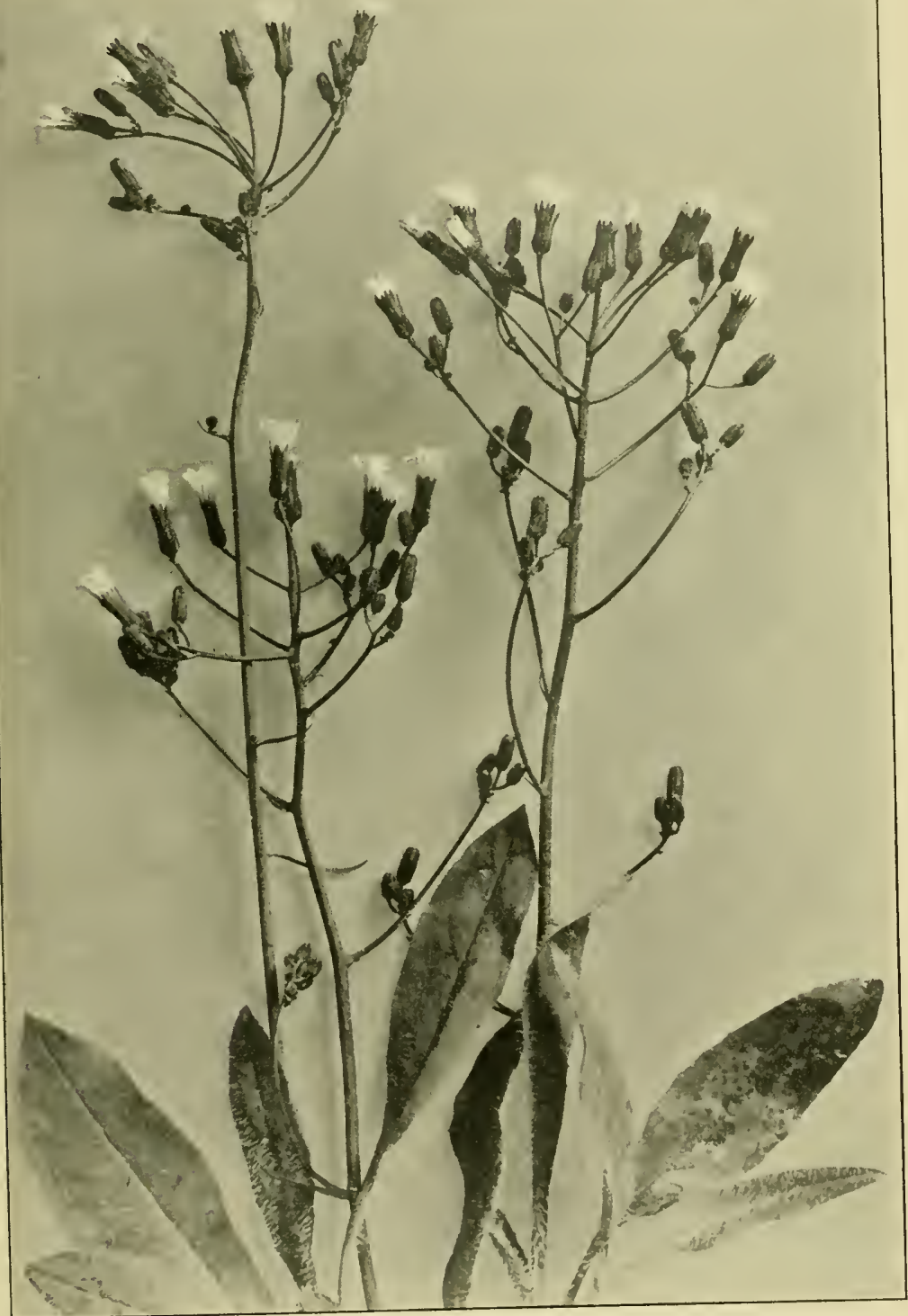

SMALL HAWKWEED

(Hieracium gracile) 



\section{YELLOW RATTLE}

Rhinanthus Crista-galli. Figwort Family

Stems: slender. Leaves: lanceolate, sessile, coarsely serrate-dentate, acute; bracts ovate, incised-dentate, the teeth acuminate. Flowers: in terminal, one-sided, leafy-bracted spikes, and solitary in the upper axils; calyx much inflated, conspicuously veiny in fruit; corolla very irregular, two-lipped; the galea compressed, arched, minutely two-toothed below the entire apex, the lower lip three-lobed, spreading.

The name Yellow Rattle has been given to this plant on account of the way in which the ripened seeds, which lie loose in the capsules, rattle whenever the wind shakes them to and fro. It is a firm erect plant, usually growing from six to ten inches high, and chiefly conspicuous by reason of its inflated green flower-cups and bright yellow blossoms, the lips of which frequently are spotted with purple.

\section{LARGE YELLOW LADY'S SLIPPER}

Cypripedium pubescens. Orchid Family

Stems: leafy. Leaves: oval or elliptic, acute. Flowers: sepals ovatelanceolate, longer than the lip, yellowish-green striped with purple; petals very narrow and twisted, lip much inflated, bright yellow with greenish-purple lines, a tuft of white jointed hairs at the top of the interior; stamen sterile, triangular; stigma thick, incurved.

In the dry sun-warmed forests, where the birds trill their sweet antiphons and the smooth surface of the pools reflects with steadfast truth the cone-laden branches of fir and pine and the fleecy clouds that float across the azure sky, - there, unafraicl, rejoicing in its weird, almost unearthly beauty, the Large Yellow Lady's Slipper flaunts its gaudy flowers.

At the first sight of these exquisite orchicls, which also grow on the open arid moraines close to the immense glaciers, you catch your breath, and a thrill runs through all your veins; there they stand, golden-bright, surrounded by a halo of romance and mystery. 
There is little need to describe this Cypripedium, for its showy inflated sac, flanked by long spiral petals and purplishgreen sepals, distinguishes it at once, even to the unpractised eye. The leaves of the Large Yellow Lady's Slipper grow alternately on the slender hairy stems, and are large, longshaped, pointed, many-nerved, and plaited. The name $C_{y^{\prime}}$ pripadium is derived from the Greek, and means Venus's sock or buskin.

C. parviflorum, or Small Yellow Lady's Slipper, much resembles the preceding species, but may be easily distinguished by means of its smaller flowers, the inflated sacs of which are of a much cleeper, richer shade of yellow, and are often marked with reddish-purple spots and lines, and also by its wider oval-shaped leaves and thicker stems.

In July, that exquisite month which lies within the very heart of summer, should you wander amid the mountains when dawn trumpets forth the glittering rise of day, then pause besicle some sluggish alpine stream, which lonely lies coiled in sleepy curves, for there, far removed from the haunts of men, you may be fortunate enough to find the fragrant little Cypripedium pariflomm.

Unlike the Large species, this Small Yellow Lady's Slipper always seeks the seclusion of the hazy hollows and the moist misty woods. Rightly have these lovely sweet-scented flowers been proclaimed

"Golden slippers meet for fairies' feet."

\section{PHILADELPHIA LILY}

\section{Lilium Philadelphicum. Lily Family}

Bulb composed of narrow, jointed, fleshy scales. Stems: tall, leafy. Leaves: lanceolate, acute at both ends, all verticillate, the margins finely roughened. Flowers: erect; perianth redclish-orange, of six spreading segments, each one gradually narrowed into a claw, purple-spotted below. 
PLATE LXXXYI

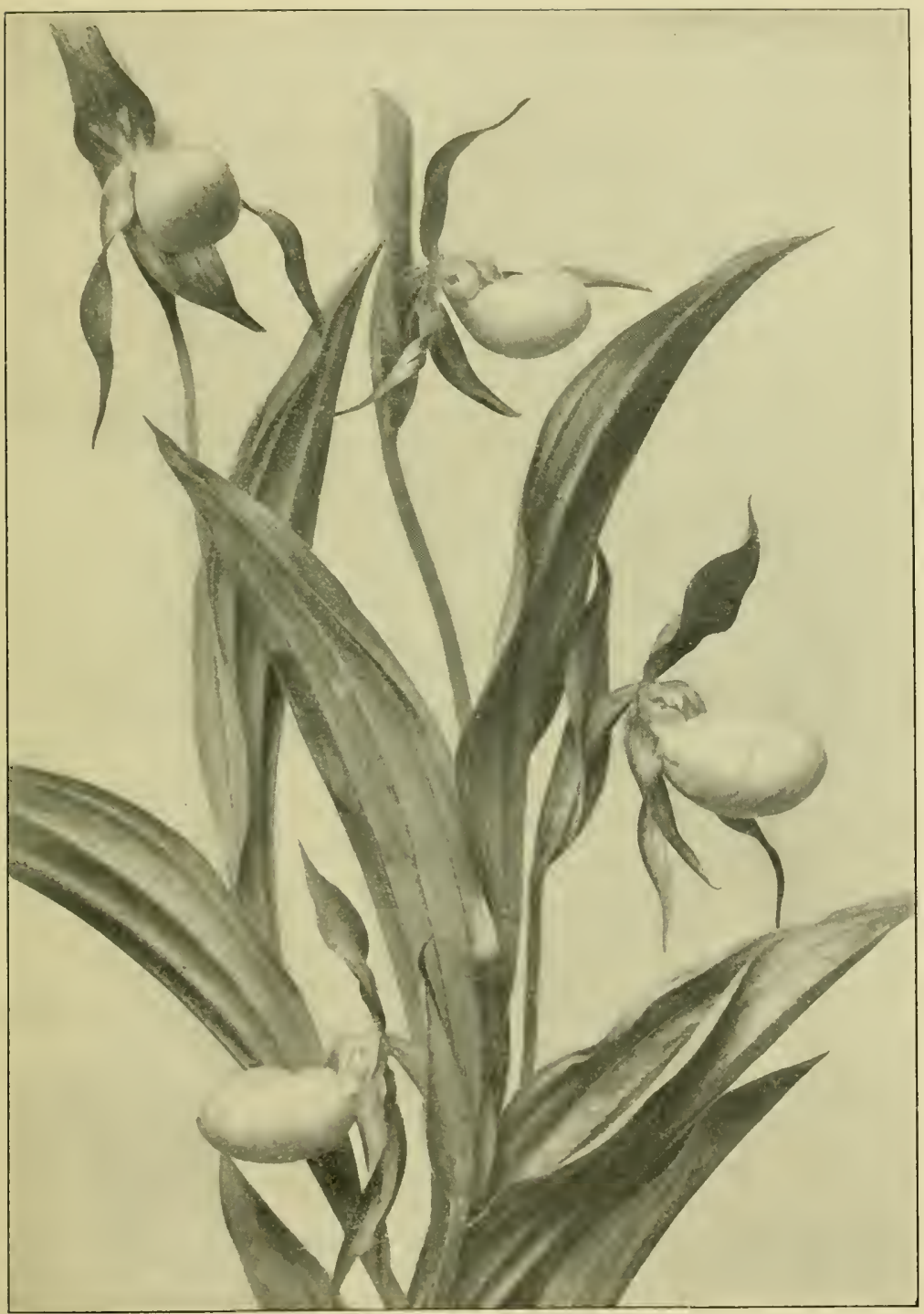

LaRge Yellow Lady's Slipper

(Cypripedium pubescens) 

Lilies grow in many climes and are of divers hues. White and yellow, orange and red, tall and stately, they flourish conspicuously in the valleys and on the mountain tops, beneath blazing tropical suns and close beside the eternal snows.

The Philadelphia Lily is one of the handsomest of the alpine flowers, and early in July its red-tinted tawny bells render the woods attractively gay. As if conscious of their glory, the large bright blossoms grow erect on tall stems, round which circling clusters of clark green narrow-pointed leaves are set at intervals; the outer surface of the segments is pale orange, while the open bells are of a vivid reddish hue within, and spotted with purplish-brown. Large anthers crown the six long stamens, and the stigma is three-lobed.

This Lily does not fear the drought of long summer days, but grows in stately splendour in the driest thickets. It has assumed a gorgeous garb of flaming orange in order to attract those insects that pollenize its flowers; for while the brilliant colour quickly attracts the bees, the purplish spots and lines unerringly point out to them the most direct route to their desired goal, namely, those nectar grooves which lie at the base of each segment.

Truly was it said that "even Solomon in all his glory was not arrayed like one of these "; for the wild orange-red Philadelphia Lilies shine with a beauty unequalled in the alpine forests.

\section{WESTERN LILY}

\section{Lilium Columbianum. Lily Family}

Bulb, with lanceolate, acute, closely appressed scales. Stems : slender. Leaves: in whorls, scattered above and below, narrowly lanceolate, sharply acuminate, thin, glabrous. Flowers: racemose, or in whorls on stout pedicels, six segments of the perianth revolute.

This Western Lily somewhat resembles the Turk's-cap Lily, for its head is drooped and its floral leaves are revolute, or 
rolled backwards, being bright orange in colour and thickly spotted with purple on the inside. It has six very long stamens, which terminate in large, oblong, yellow anthers; the segments of the perianth are not clawed, as in the Philadelphia Lily, but are joined together at the base, forming a perfect bell.

As in all the species of Lilium, the bulb consists of a large number of overlapping scales, which are merely thickened, undeveloped leaves, serving as storehouses for the starchy wealth of the plant. Any one of these scales, if separated from the mass, will develop into a tiny bulb.

Very radiant are these clustered Western Lilies, which burn like torches in the green alpine meadows at

"The time when lilies blow,

And clouds are highest in the air."

\section{YELLOW ADDER'S TONGUE}

\section{Erythronium giganteum. Lily Family}

Stems: scape stout. Leaves: broadly lanceolate, acute, pale green. Flowers: one to several in a terminal raceme; perianth broadly funnelform, of six distinct segments : outer ones lanceolate, obtuse ; inner ones narrower, acuminate, with four stout hyaline teeth at base, all strongly revolute.

A lovely yellow flower, frequently called "Snow Lily," from the fact that it grows in such close proximity to the great alpine névés. "Dog-tooth Violet" is yet another name for this plant, and refers more particularly to the white bulb, which is supposed to resemble the canine teeth of a dog.

Adder's Tongue probably refers to the pointed anthers, which are six in number and extremely conspicuous; but "Snow Lily" is by far the more appropriate designation for a blossom which appears at the edge of the avalanches and follows the retreating line of the snow when the warm spring sunshine melts the great white masses in the valleys and 
sets the flowers free. At high altitudes you will often see numbers of pale green pointed leaves forcing their way up through the soft covering, and myriads of bright yellow blossoms rising but a few inches above the thin carpet of frozen crystals. From between two or three of these large leaves (somewhat like those of the Lily-of-the-Valley) springs the slender stalk, which terminates in a single bud, or occasionally in a small raceme of drooping golden bells. Soon the six pointed segments of the perianth unfold and expand, gradually rolling backwards until they become completely recurved, leaving the whole length of the stamens exposed. These segments, or floral leaves, are an exquisite shade of yellow, softening to cream colour at the base in the centre. The style bears at its summit a deeply three-cleft stigma, each division thereof being also recurved.

Great colonies of Yellow Adder's Tongues grow in the mountains, where their faint fragrance scents the air with a delicious perfume. Late at evening, when beneath the starsown purple of the sky you return from making some alpine ascent, the pure flames of these wild Lilies gleam in their leafy setting with a pale golden light, and illuminate the green brink of your path; and when the noonday is glorified, and the flag of the sun floats top-masted in the skies, then

"You see gems in yellow

Nodding, each one, to his fellow,

Strewing all the country lanes

With divinely builded fanes,

Where the benisons are breathed but never spoken." 

MOUNTAIN WILD FLOWERS

OF AMERICA

Section V

FLOWERING SHRUBS 



\section{Section V \\ FLOWERING SHRUBS}

\section{RED BANEBERRY}

Actac spicata viar. arguta. Crowfoot Family

Stems : one to six feet high from a fascicle of short branching roots. Leaves: ternate, the divisions pinnate, with the lower ultimate leaflets sometimes again compound, ovate, sometimes obscurely three-lobed, toothed. Flowers : in oblong terminal racemes, sometimes divided towards the base, loose; petals oblong, obtuse. Fruit: berries red, oval, manyseeded.

The Red Baneberry is a perennial herb, not a shrub; but since it grows to the height of six feet, and is a very large bushy plant, it has been placed in this Section for greater convenience. The foliage is abundant and coarsely veined, and the tiny flowers, which grow in oblong, close-set, terminal racemes, are feathery and delicate in appearance. This plant usually flourishes in the dense forest glades, where the dainty white blossoms and clusters of bright red berries adorning its slender stalks render it both attractive and conspicuous.

\section{ROCKY MOUNTAIN GRAPE}

\section{Berberis repens. Barberry Family}

A low glabrous shrub. Leaves: petioled, pinnate, the leaflets three to seven, ovate, obtuse, truncate at the base, sessile, thick, finely reticulated, dentate with spine-bearing teeth. Flowers: in short racemes, the clusters terminal and axillary, many-flowered, yellow. Fruit: a globose dark blue berry. 
This shrub, which is exceedingly ornamental, has yellow wood and bright green foliage, which turns to a lovely reddish colour in the autumn. The tiny vivid yellow flowers grow in short thick clusters; they have six bracted sepals, with six petals opposite them, also six stamens.

\section{CHOKE CHERRY}

\section{Prunus Tirginiana. Rose Family}

A shrub two to ten feet high, or very rarely a small tree, with gray bark. Leaves: thin, obovate, abruptly acute, rounded at the base, sharply serrulate with slender teeth. Flowers: white, in erect or spreading, mainly loosely-flowered racemes terminating the leafy branches of the season; calyx five-cleft; corolla of five suborbicular spreading petals. Fruit: a dark red drupe, globose, very astringent, stone globular.

This tall shrub, or tree, bears abundant white blossoms, which grow in long graceful racemes amid the dark green leaves. These leaves are broadly oval in outline and finely edged with numerous tiny sharp teeth. It is in this latter characteristic that the Prunus differs materially from Amelanchicr alnifolia, or Service-berry, with which it is sometimes confused. The Service-berry has smaller roundish leaves, edged above the middle with marked teeth, and its blossoms are larger and fewer in number.

The Choke Cherry grows from 1000 to 3000 feet above sea level, and the profusion of its snowy sweet-scented flowerclusters, which are followed in due comse by the dark red semi-transparent fruit, renders it a great ormament to the alpine mountain sides. This fruit is edible, but very astringent, and contains a tiny round stone. 


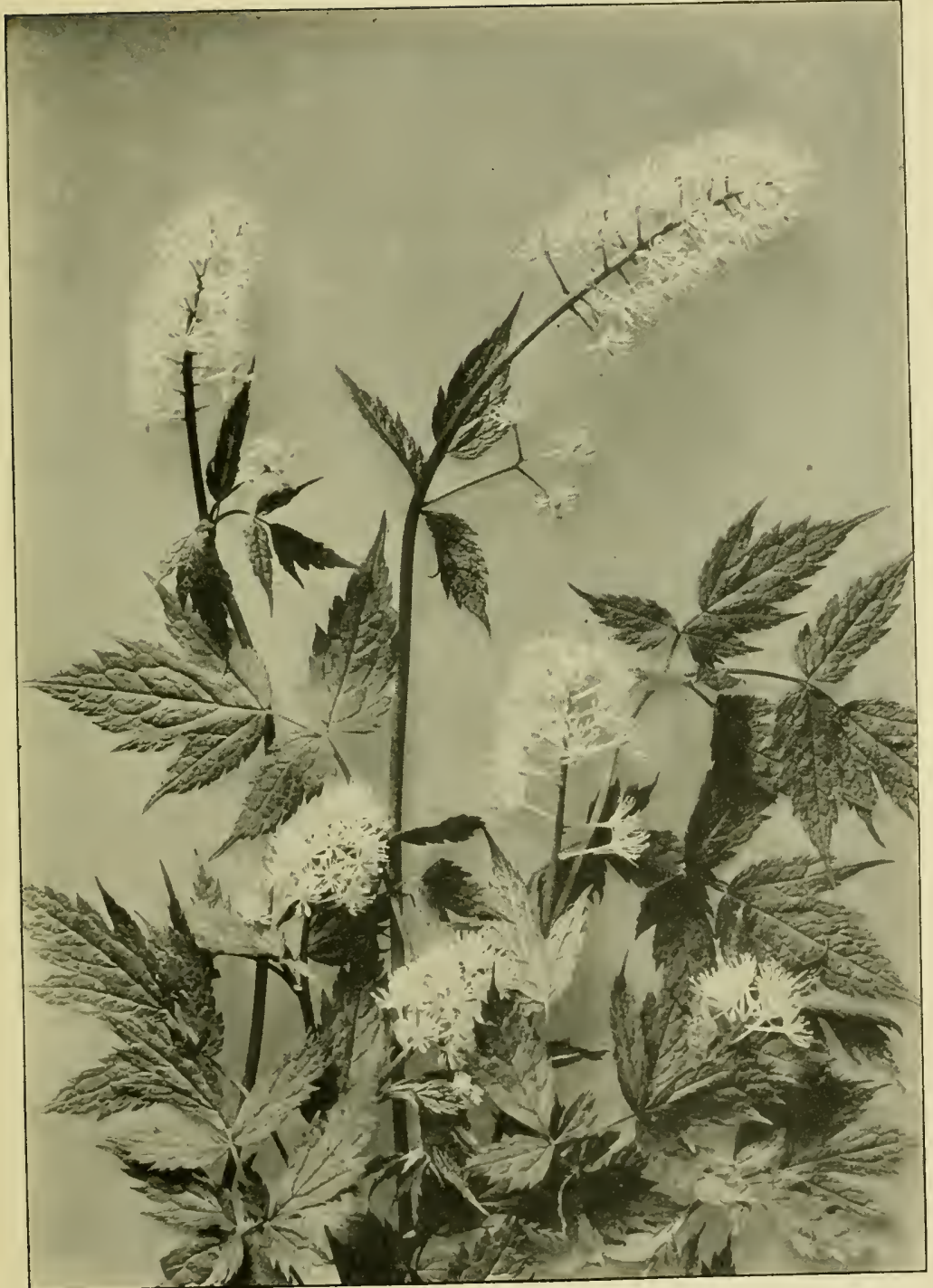

RED BANEBERRY

(Actaa spicata var. arguta) 



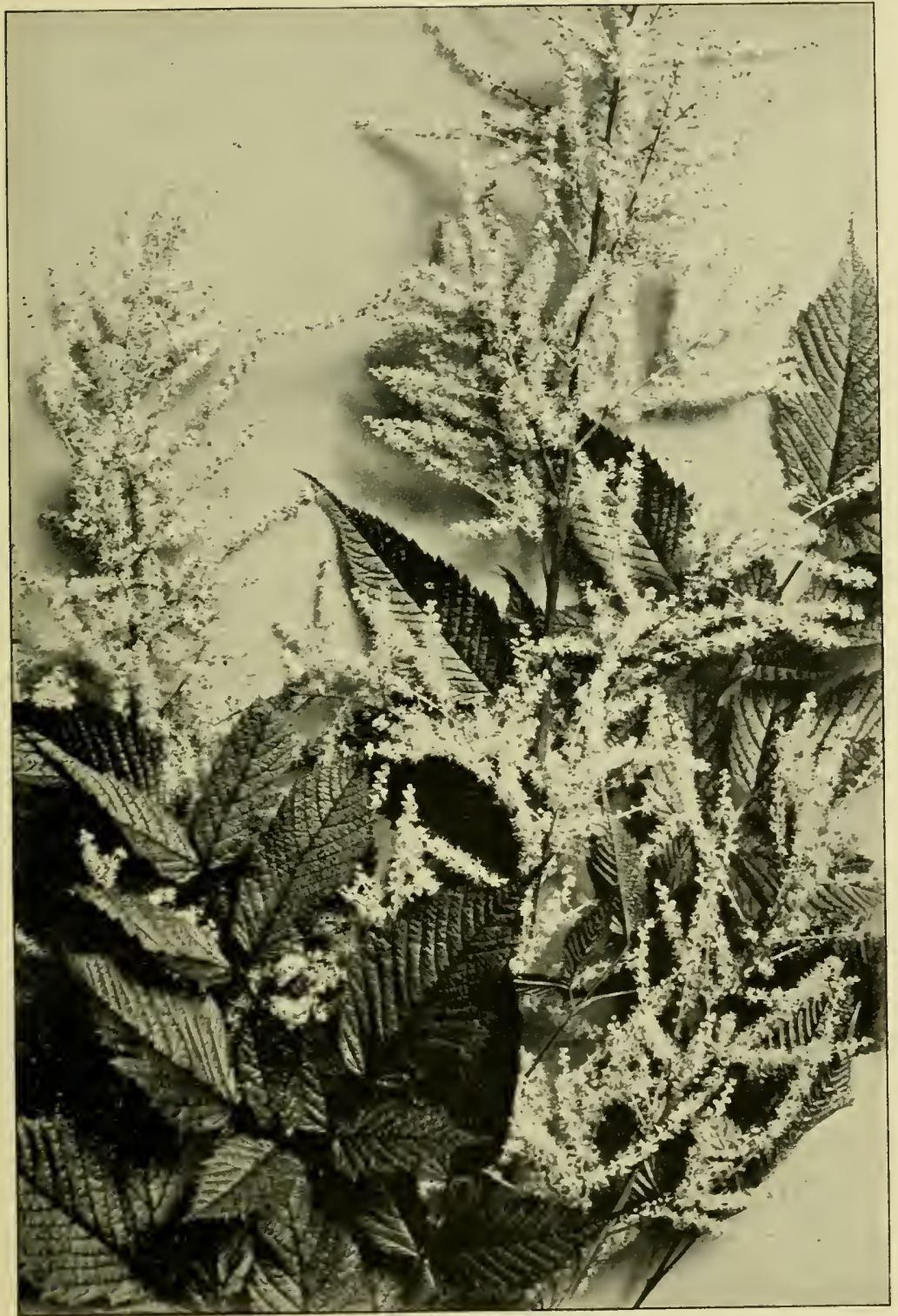

GOAT'S BEARD

(Spirca.Aruncus) 



\section{GOAT'S BEARD}

Spirad Aruncus. Rose Family

Stems : erect, bracted. Leaves: long-petioled, pinnate, three-to-seven foliolate; leaflets ovate, lanceolate, thin, acute at the apex, rounded at the base, sharply doubly serrate. Flowers: in long, slender, panicled spikes, erect or spreading.

This is another tall, shrub-like, perennial herb, placed in this Section for greater convenience. It is quite unmistakable, as it grows from three to ten feet high in the rich soil of the wet valleys, and bears numerous long showy plumes of closely clustered, minute, creamy flowers rising above its masses of luxuriant strongly veined foliage. Thus the Goat's Beard is both decorative and conspicuous. The tiny flowers are formed of a five-lobed calyx and five petals, and the seeds are very small and shining.

\section{SALMON-BERRY}

Rubus Nutkanus. Rose Family

Erect, branched, very slightly bristly. Leaves : petioled, simple, cordate at the base, threc-to-five lobed, the lobes acute, the middle one slightly longer than the others, all coarsely and unequally serrate. Flowers: white, few, corymbose, terminal ; calyx-lobes tipped with a long slender appendage. Fruit: depressed-hemispheric, edible, red when ripe.

The five snow-white crinkled petals of the Salmon-berry look very frail and pretty when seen amid the dense coarse foliage of this large bushy shrub. The flower is formed like a miniature white rose, and has numerous tiny stamens set around the convex receptacle in which are inserted the carpels that ultimately ripen into drupelets and form an agrgregate red fruit.

The Salmon-berry grows abundantly in the

" High-wooded hollows, where serenely rest

The lazy clouds, like giants in repose." 


\section{SHRUBBY CINQUEFOIL}

\section{Potentilla fruticosa. Rose Family}

Stems: erect or ascending, much branched, very leafy, the bark shreddy. Leaves : pinnate; leaflets five to seven, oblong, acute at each end, silky-pubescent, the margins revolute. Flowers : terminal, densely cymose or solitary, bright yellow; petals five, nearly orbicular in outline, exceeding the five ovate calyx-lobes and five bractlets.

In July and August the dry sunny alpine meadows are rendered gay by these lovely bright yellow Cinquefoils, which resemble large buttercups and grow on low bushy shrubs, amid much silvery foliage, composed of tiny compound leaves covered with a soft silky down. The bark on the slender stems is extremely shreddy.

\section{PRICKLY ROSE}

\section{Rosa acicularis. Rose Family}

Stems : densely prickly. Leaves : pinnate; leaflets large, five to seven, oval-lanceolate, coarsely toothed. Flowers : solitary; petals pink, broadly obovate; sepals entire, acuminate, persistent and erect upon the fruit. Fruit: globose, glabrous.

The bush on which this Rose grows is about three feet high and bears lovely, fragrant, pale pink flowers. The leaves are large and very dark green, and the stems are covered with many tiny, fine, straight prickles. All the wild Roses display a preference for the number five, having five petals and five sepals.

No flower in the world has been so famous in poetry and song as the Rose. Its beauty and fragrance have won for it an honoured place in the annals of history, in classic lore, and in the glowing pages of romance.

"Was ever blossom lovelier than the rose?"

Surely not. Nor can we agree with Juliet when she says:

"That which we call a rose

By any other name would smell as sweet." 
PLATE LXXXIX

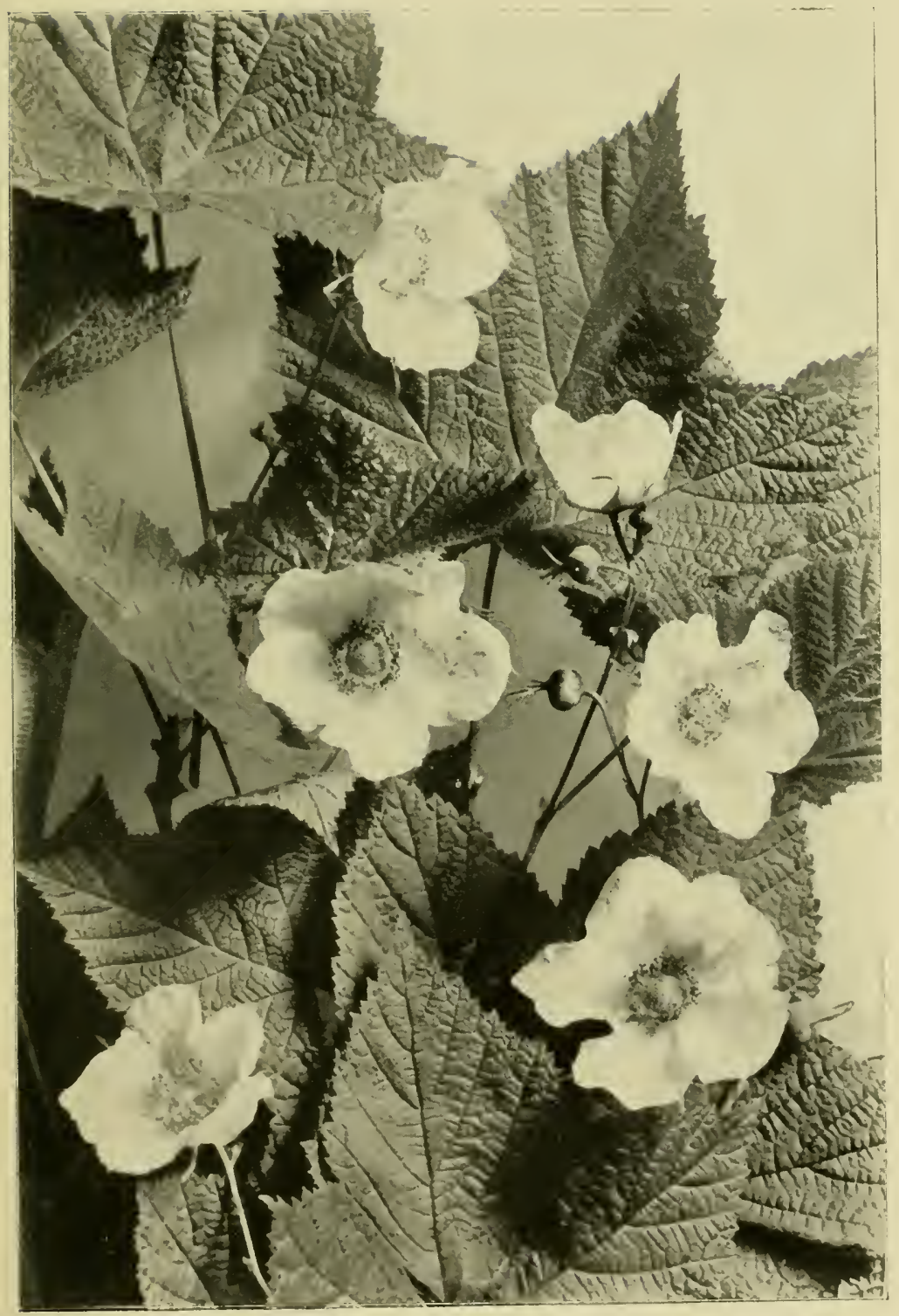

SALMON-BERRY

(Rubus Nutkanus) 

PLATE XC

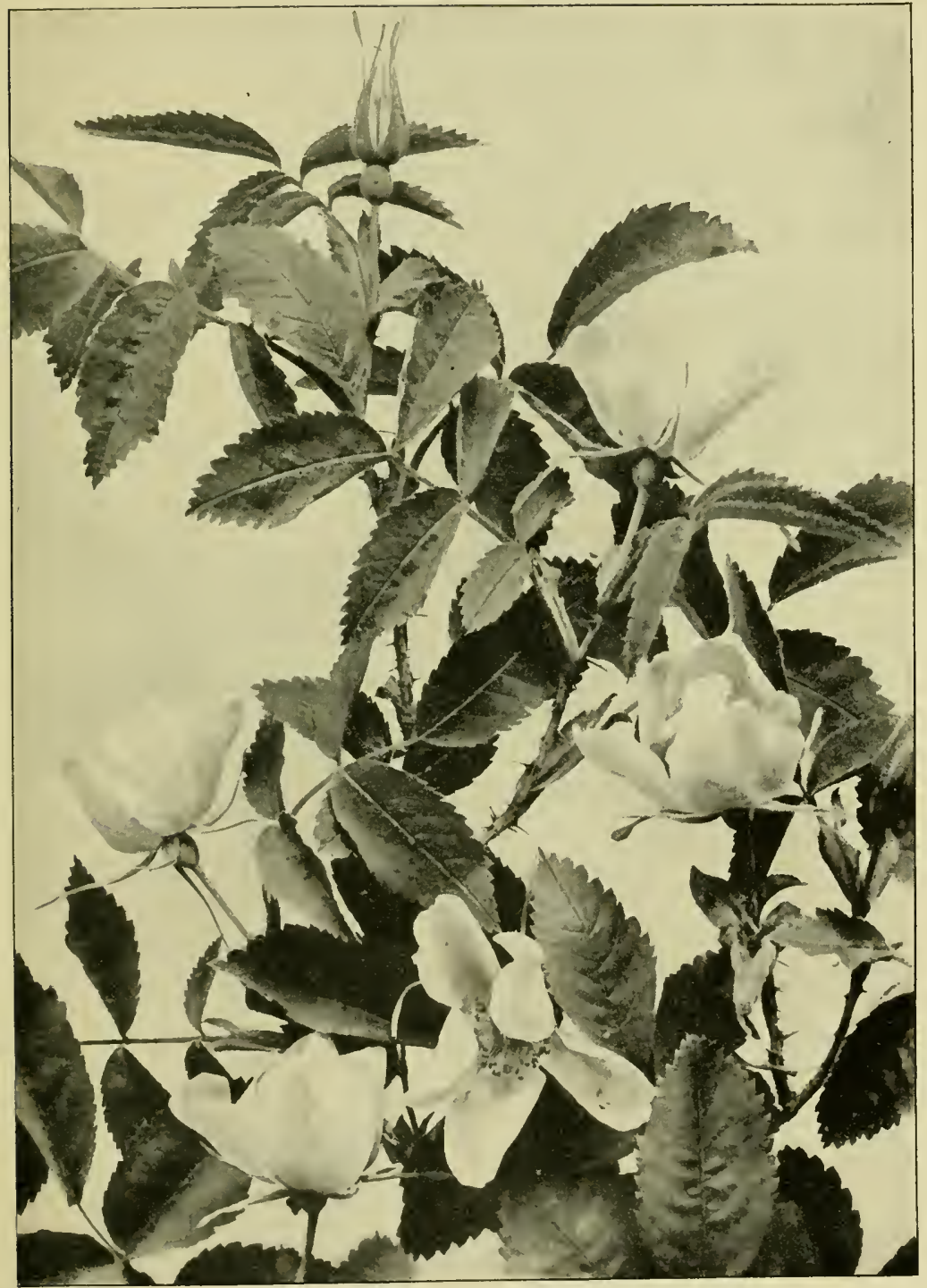

PRICKLY ROSE.

(Rosa acicularis) 

For to us the Rose symbolizes those things which are tender and exquisite in life, and the sweet wild dweller in the forest is the fairest flower of them all.

"If June were mine, I'd weave for you -

Of roses red and slies of blue,

Of golden sun and orchard sheen,

Of blossom-fretted damascene -

$A$ veil of every petal-hue.

"And from the morning mists of dew

Distil a fairy stream, that through

The woods should wend a way serene,

If June were mine.

"And, ere the purple dusk anew

The curtains of the sunset drew,

Adown the river's dream demesne,

I'd paint a path incarnadine, And drift in to the dawn with you, If June were mine."

R. Macomizi, or Macoun's Rose, is another species which grows among the mountains. Note that it has small leaves, and that on its stems grow a few large, widely separated, hooked thorns. Otherwise it resembles R. acicularis, and the flowers of the two bushes are almost identically alike. When

"The last rose of summer, Left blooming alone,"

hangs on the bush surrounded by the fallen petals of her companions, then

"Scarlet berries tell where bloomed the sweet wild rose."

and Nature spreads a feast of ripe red fruit for the birds of the air. 
I cannot refrain from closing this brief mention of the Rose with a quotation from a poem by Isabella Valancy Crawford, the sweetest singer of songs Canada ever knew :

"The rose was given to Man for this:

$\mathrm{He}$, sudden seeing it in later years,

Should swift remember Love's first lingering kiss,

And Grief's last lingering tears.

"Or, being blind, should feel its yearning soul

Knit all its piercing perfume round his own,

Till he should see on Memory's ample scroll

All roses he had known."

\section{WESTERN MOUNTAIN ASH}

Pyrus sambucifolia. Rose Family

Leaves: alternate, pinnate ; leaflets seven to fifteen, lanceolate, shortpointed at the apex, sharply serrate, glabrous and dark green above, pale and more or less pubescent beneath. Flowers : white, in terminal compound cymes; calyx-tube urn-shaped, five-lobed, not bracteolate; petals five, spreading, short-clawed. Fruit: a small, red, berry-like pome, bitter.

This is the Rowan Tree of the mountain regions, and a very handsome shrub or tree it is, sometimes attaining a height of twenty feet, but usually growing only from six to fifteen feet high.

The leaves are dark green on the top and a much paler hue beneath. The flower-buds are a delicate shade of creamy pink, and turn white when they expand in the sumshine, the wideopen blossoms having a darkened appearance in their centres, caused by the numerous stamens. This shrub is found at great altitudes, growing close to the edge of perpetual snow and bearing quantities of splendid foliage and huge clustered cymes of soft-tinted flowers, which diffuse an extremely pungent odour. 
The Rowan Tree is famed in verse and legend, but surely no tenderer poem was ever penned in its honour than the old immortal song :

"O Rowan tree! O Rowan tree! thou 'lt aye be dear to me; Entwined thou art wi' mony ties o' hame and infancy.

Thy leaves were aye the first o' spring, thy flowers the simmer's pride; There was nae sic a bonnie tree in a' the countrie side,

O Rowan tree!

"How fair wert thou in simmer time, wi' a' thy clusters white! How rich and gay thy autumn dress, wi' berries red and bright! We sat aneath thy spreading shade; the bairnies round thee ran; They pu'd thy bonnie berries red, and necklaces they strang,

O Rowan tree!"

\section{SERVICE-BERRY}

Amelanchier alnifolia. Rose Family

A shrub three to six feet high, more or less tomentose-pubescent when young, at length glabrate throughout and somewhat glaucous. Leaves: thick, broadly elliptic or orbicular, very obtuse, and of ten truncate at the apex, rounded or subcordate at the base, coarsely dentate above the middle. Flowers: white, in short racemes, rather dense; petals five, oblanceolate, cuneate. Fruit: a globose pome, purple with a bloom, sweet.

This is the low pearly-flowered shrub which grows on the sandy banks and flats, and which the Indians call Saskatoon, for its sweet purple berries form a staple article of food with them during the months of July and August. It somewhat resembles the Choke Cherry, but its greenish-white blossoms are larger and have long narrow petals; also its leaves are oval, with flattened ends, and are very coarsely toothed above the middle, whereas those of the Choke Cherry are oblong, pointed, and finely toothed all round the edges. The bark of the little branches of the Service-berry is reddish, and the young leaves are quite pale and downy underneath. 


\section{BRISTLY GOOSEBERRY}

Ribes setosum. Saxifrage Family

Stems : with infra-axillary spines, slender, spreading, sometimes none; bristles usually numerous, scattered. Leaves: slender-petioled, broadly ovate in outline, five-lobed, the lobes incised-dentate. Flowers : greenishwhite; calyx-tube cylindric, longer than the oblong lobes: stamens not exserted. Fruit: a globose purple berry, pulpy, the calyx persistent on its summit, sparingly bristly or often glabrous.

The bush on which this Bristly Gooseberry grows is found in the shady woods, and attains an average height of three feet. The flowers are greenish-white and very insignificant, and the fruit consists of a small purple pulpy berry, which is sweet to the taste.

\section{RED CURRANT}

\section{Ribes rubrum. Saxifrage Family}

Unarmed. Leaves : pubescent beneath, orbicular, three-to-five lobed, cordate at the base, the lobes obtuse, sharply dentate. Flowers: in greenish to purplish racemes, pendulous, loosely flowered: calyx flat, campanulate; stamens short. Fruit: red, glabrous.

This is the wild counterpart of our cultivated Garden Currant. In the shadowy depths of the mountain forests the pendent tassels of tiny greenish or purplish flowers are seldom noticed, and the small recl fruit is not at all palatable, being extremely acid and possessing a woody flavour.

\section{DEVIL'S CLUB}

\section{Fatsia horrida. Ginseng Family}

Stems: stout, two to twelve feet high, decumbent at the base, leafy at the summit, very prickly throughout. Leaves: palmately lolock. Flowers: the greenish-white capitate umbels in a long dense raceme; caly $\mathbf{x}$-teeth obsolete: petals five, valvate in the bud; stamens five, alternate with the petals; filaments fiiiform. Fruit: drupaceous. 


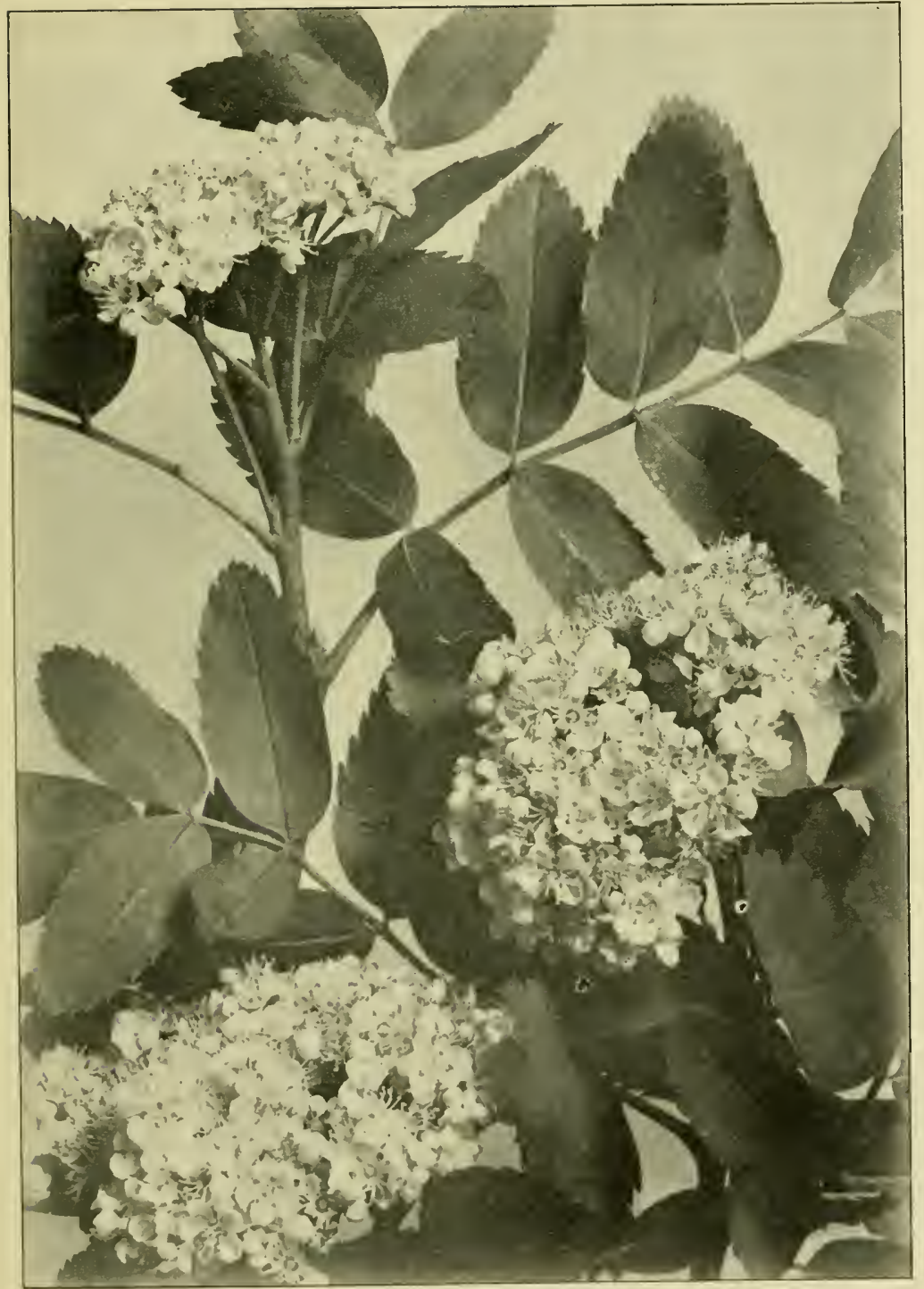

Western Mountain Ash

(Pyrus sambucifolia) 



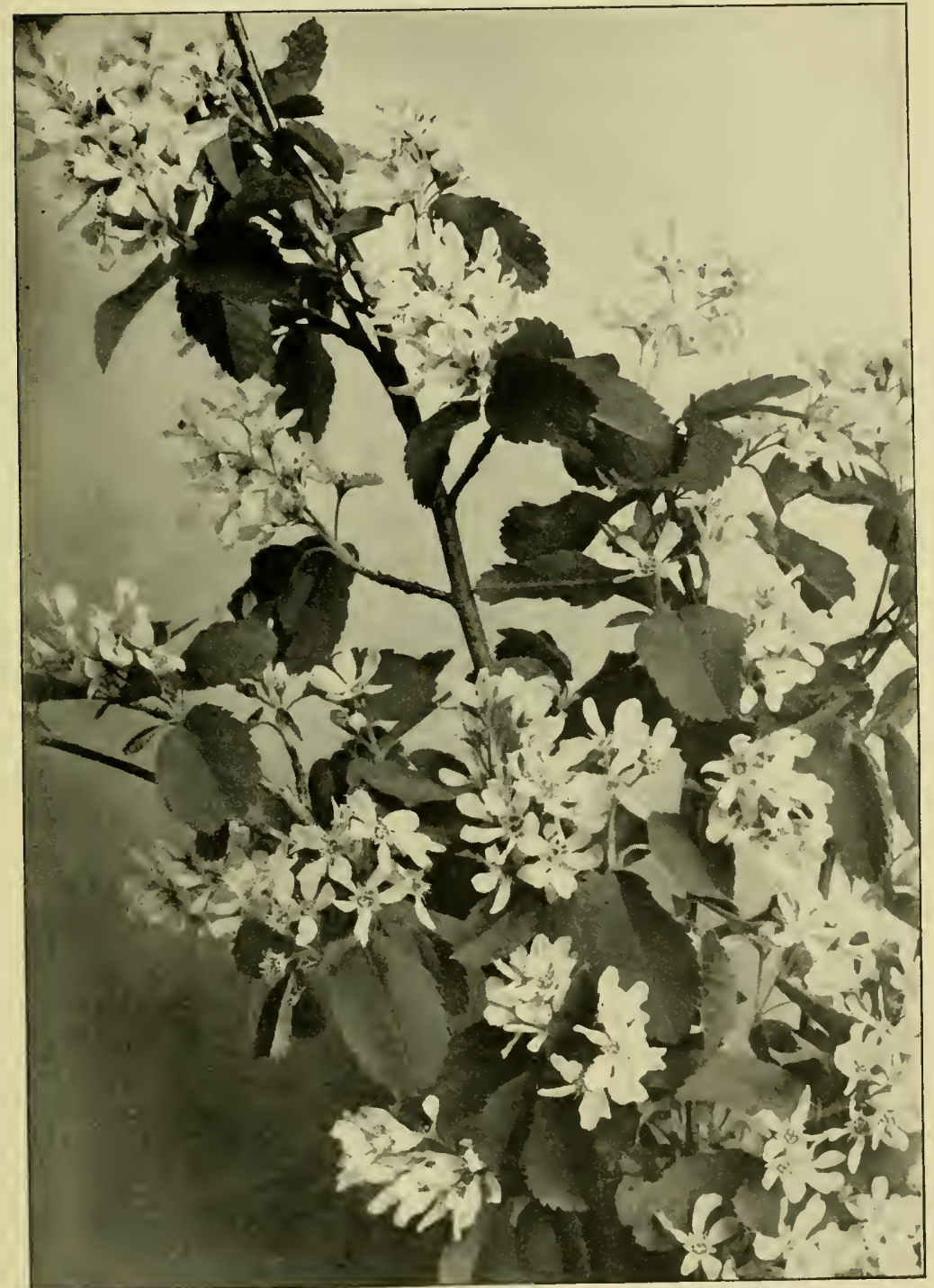

SERVICE-BERr

(Amelanchier alnifolia) 

A tall shrub consisting of a single stout stem corered with long sharp spines, which are extremely poisonous. It usually grows about six or eight feet high, and has huge palm-like leares, which are also prickly. The flowers grow in a dense cluster at the top of the stem, and in time turn into bright red berries.

This plant should be carefully avoided in the forests. It has been rightly named "Devil's Club," since no human being may touch it with impunity.

\section{RED-STEMMED DOGWOOD}

Comus stolonifera. Dogwood Family

Stems: red. Leaves: slender-petioled, ovate, acuminate at the apex, rounded at the base, entire. Flowers: in cymes, flat-topped; petals white. Fruit : globose, blue.

A handsome shrub, with bright red stems and numerous flat-topped clusters of pretty little greenish-white flowers, which have a very fragrant olour. The Western Indians call it Kinnikinnic, and chry and use the inner bark in place of tobacco; while the half-breeds of the plains call it Herrouge, signifying "a red switch."

\section{RED-BERRIED ELDER}

Sambucus racemosa. Honeysuckle Family

Stems: woody. Leaves: pinnately compound; leaflets lanceolate, acuminate at the apex, sharply serrate. Flowers: in thyrsoid cymes, white to yellowish. Fruit: small, scarlet.

This shrub, which grows from ten to thirty feet high and has spreading branches and ample foliage, is widcly distributed orer the continent. In fields and forests, by the roadsides and in neglected gardens, you will find it springing up and thriving with undaunted hardihood amid the most barren surroundings. It also grows at many elevations, being seen in 
quantities at the sea level and also flourishing abundantly at an altitude of 6000 and 7000 feet. The leaves are divided into from five to seven leaflets, and the creamy fragrant flowers grow in elongated clusters at the ends of the branches. The fruit is a bright scarlet drupe, with a pungent acid flavour.

S. mclanocarpa, or Black-berried Elder, does not grow quite so luxuriantly as the preceding species, yet its sweet-scented misty clusters adorn many a patch and thicket. The fruit, as the name denotes, is a rich blue-black colour and very juicy. It is from this shrub that Elderberry wine is made.

\section{ARROW-WOOD}

liburnum pauciforum. Honeysuckle Family

Leaves: broadly oval, obovate, with three rather shallow lobes above the micldle, coarsely and unequally dentate, glabrous above, more or less pubescent beneath. Flowers: white, in compound cymes, all perfect and small; corolla campanulate, five-lobed. Fruit: drupes globose, bright red, acid.

A straggling shrub growing from two to six feet high and bearing many small clusters of tiny white and pinkish flowers, whose bell-shaped corollas are divided into five lobes above the middle and are pointed and coarsely toothed.

\section{SNOW-BERRY}

Symphoricarpus racemosus rar. pauciflorus. Honeysuckle Family

Leaves: opposite, broadly oval, entire, softly pubescent. Flowers: solitary in the upper axils, and two or three in the terminal spike; corolla campanulate, five-lobed, bearded within; stamens and style includecl. Fruit: a white berry.

When in flower this low spreading shrub bears its small white or pinkish bells in tiny clusters at the ends of the numerous upright branches, and also singly in the upper axils of the leaves. IVhen in fruit the pretty, white, waxen berries 


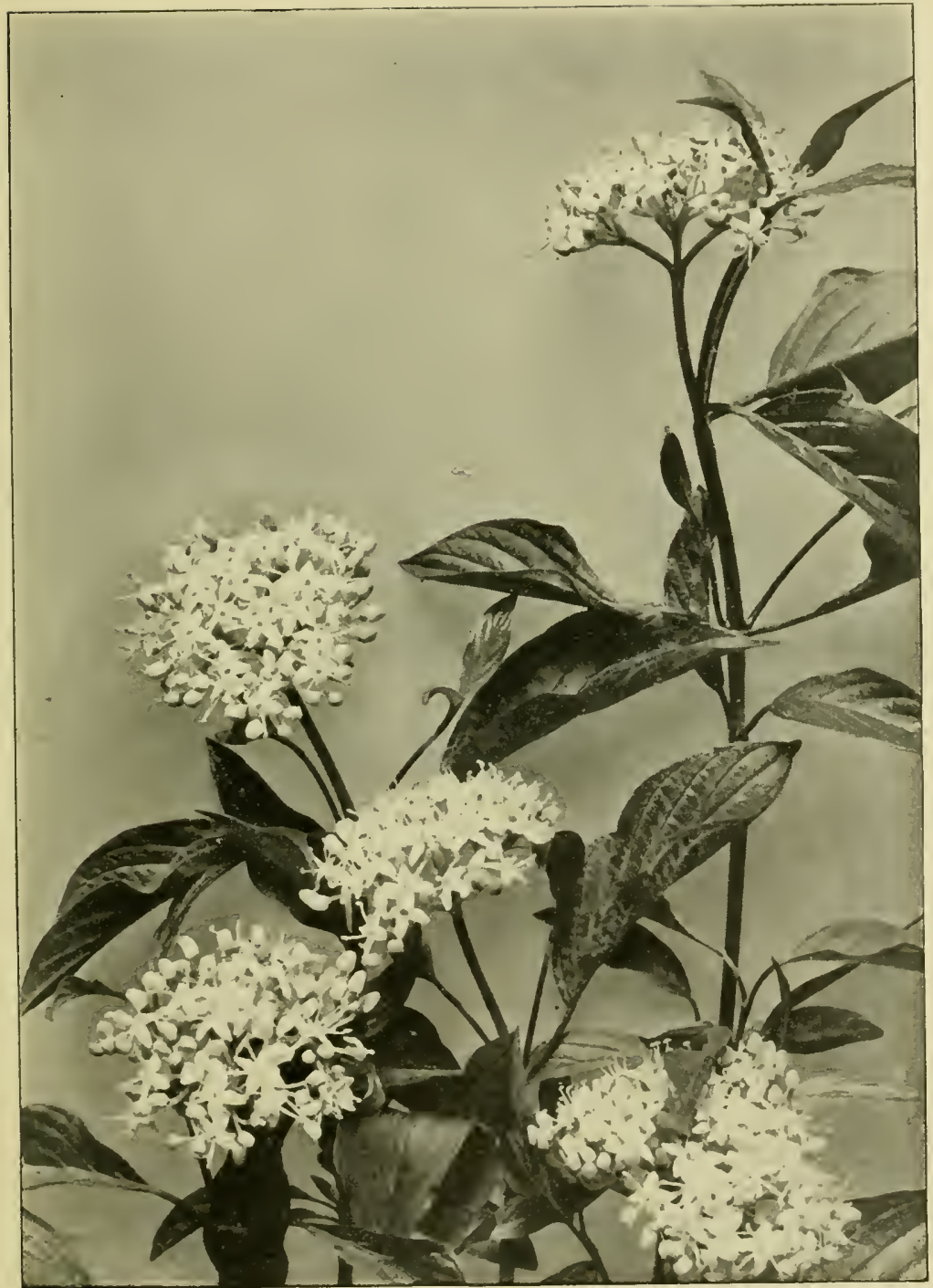

RED-STEMNED DOGWOOD

(Cormus stolonifera) 



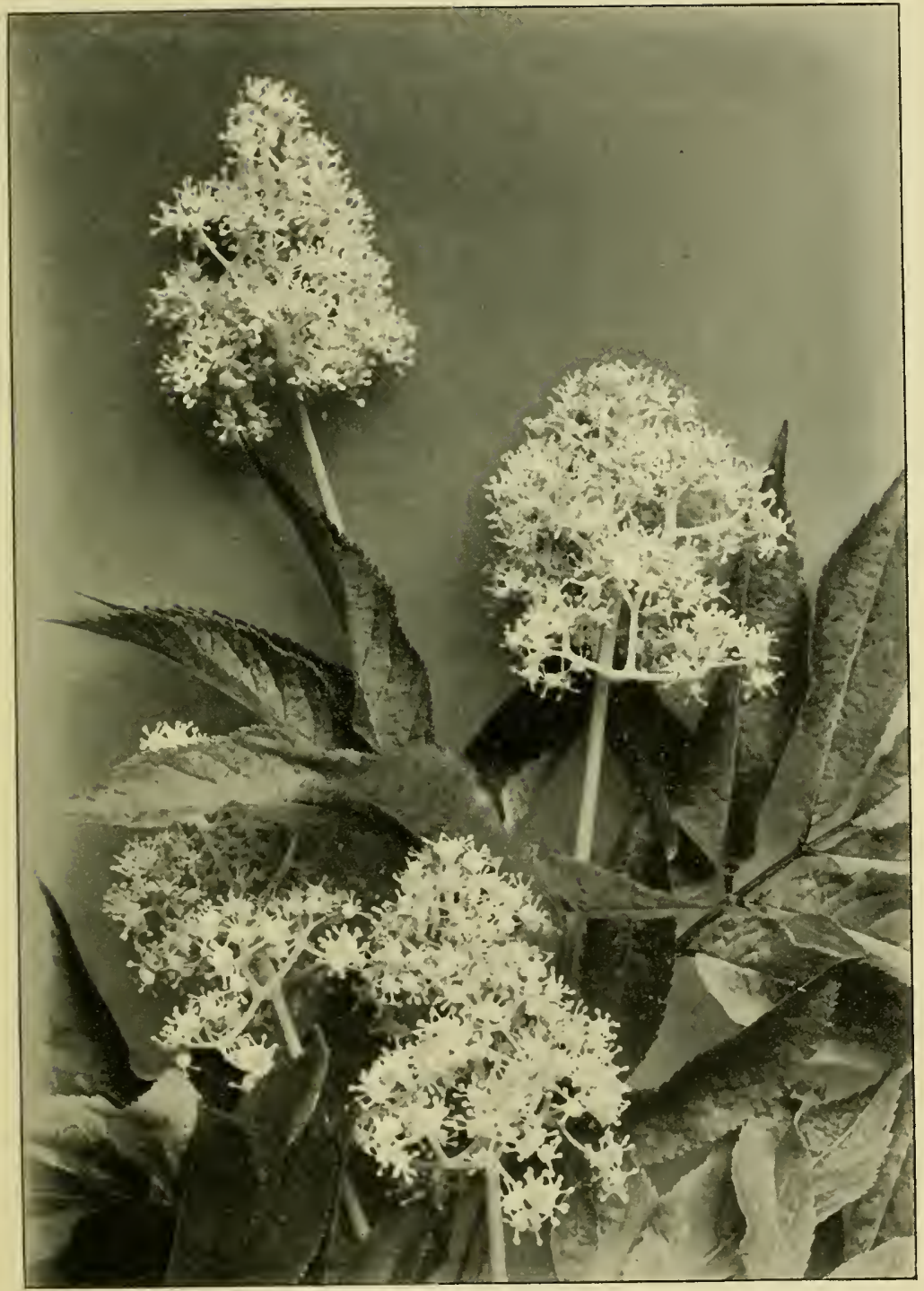

Reid-Berried Elder

(Simbucus racemosi) 

render the Symphoricarpus both conspicuous and attractive. These berries are oval in the early stages of development, when with their snowy weight they bend down the flexible branches, and become rouncled at maturity. They contain two brown bony seeds, embedded in the granular cellular pulp. The clark green leaves are broadly oval in shape and have smooth margins.

The Snow-berry is frequently cultivated in gardens as an ornamental shrub.

\section{INVOLUCRED FLY-HONEYSUCKLE}

\section{Lonicera involuerata. Honeysuckle Family}

Leaves: ovate or oval, acute or acuminate at the apex, narrowed at the base; peduncles axillary; bracts foliaceous, ovate; bractlets also large, at length surrounding the fruit. Flowers : in pairs, yellow; corolla pubescent, funnel-form, the limb five-lobed, the lobes short, little spreading; stamens and style slightly exserted. Fruit: berries nearly black.

This is one of the small-flowered Honeysuckles which grow in the form of a bushy shrub. It bears yellow funnel-form twin blossoms, terminating the long slender peduncles which spring from the axils of the leaves. These blossoms are conspicuously involucred (hence the common name) by large broad leaf-like bracts, which are green in the flowering season and turn a warm recldish colour in autumn, when surrounding the fruit. The five stamens protrude slightly beyond the corolla, but the style is much exserted, and is tipped by a large anther.

The Fly-Honeysuckle is a straggling shrub, growing from two to six feet high; the leaves are long-shaped and have hairy margins, and when in fruit the reddish-black berries are joined together in pairs. It is not a plant that is likely to attract the traveller's interest, for it is noticeable only by reason of its rich luxuriant foliage, since the flowers are small and the berries quite dark in hue. 


\section{BUSH FLY-HONEYSUCKLE}

\section{Loniccra Utahensis. Honeysuckle Family}

Leaves: oblong, subcordate at the base, obtuse, glabrous; peduncles axillary; bracts short. Flowers : corolla campanulate, obtusely saccate at the base, bilabiate, the lobes short; style included. Fruit: red berries, nearly distinct, globular.

This Fly-Honeysuckle grows from three to five feet high, and is branching and very bushy. The leaves are oblong and bright green and have wavy smooth margins. The pale yellow flowers, whose corollas are cleft into two lips, grow in pairs on long slender peluncles from the axils of the leaves, and are subtended by small bracts, in which latter respect they differ materially from the Involucred Fly-Honeysuckle, which has very large broad bracts. The fruit consists of eggshaped berries, which are more or less joined together and are of a lovely translucent scarlet colour, -

"Like a double cherry, seeming parted."

\section{BLUEBERRY}

Vaccinium oralifolium. Huckleberry Family

Leaves : alternate, oval, short-petioled, glabrous on both sides, rounded at both ends or somewhat narrowed at the base, thin, entire. Flowers: white and pink, commonly solitary in the axils on rather short recurved pedicels; calyx-limb slightly toothed; corolla globose-ovoid, toothed: stamens ten. Fruit: a many-seeded blue berry with a bloom, acid.

There are in the mountain regions many species of l'accinium that bear edible berries, but the Blueberry and the Black Vaccinium (a description of which is given below) are the most conspicuous in fruit, the former having blue berries covered with a rich soft bloom and possessing an acid though not unpalatable flavour, and the latter having purplish-black berries that are quite sweet and pleasant to the taste.

The Blueberry is a branching shrub, growing from three to ten feet high, and has smooth twigs that are sharply angled 
PIATE XCV

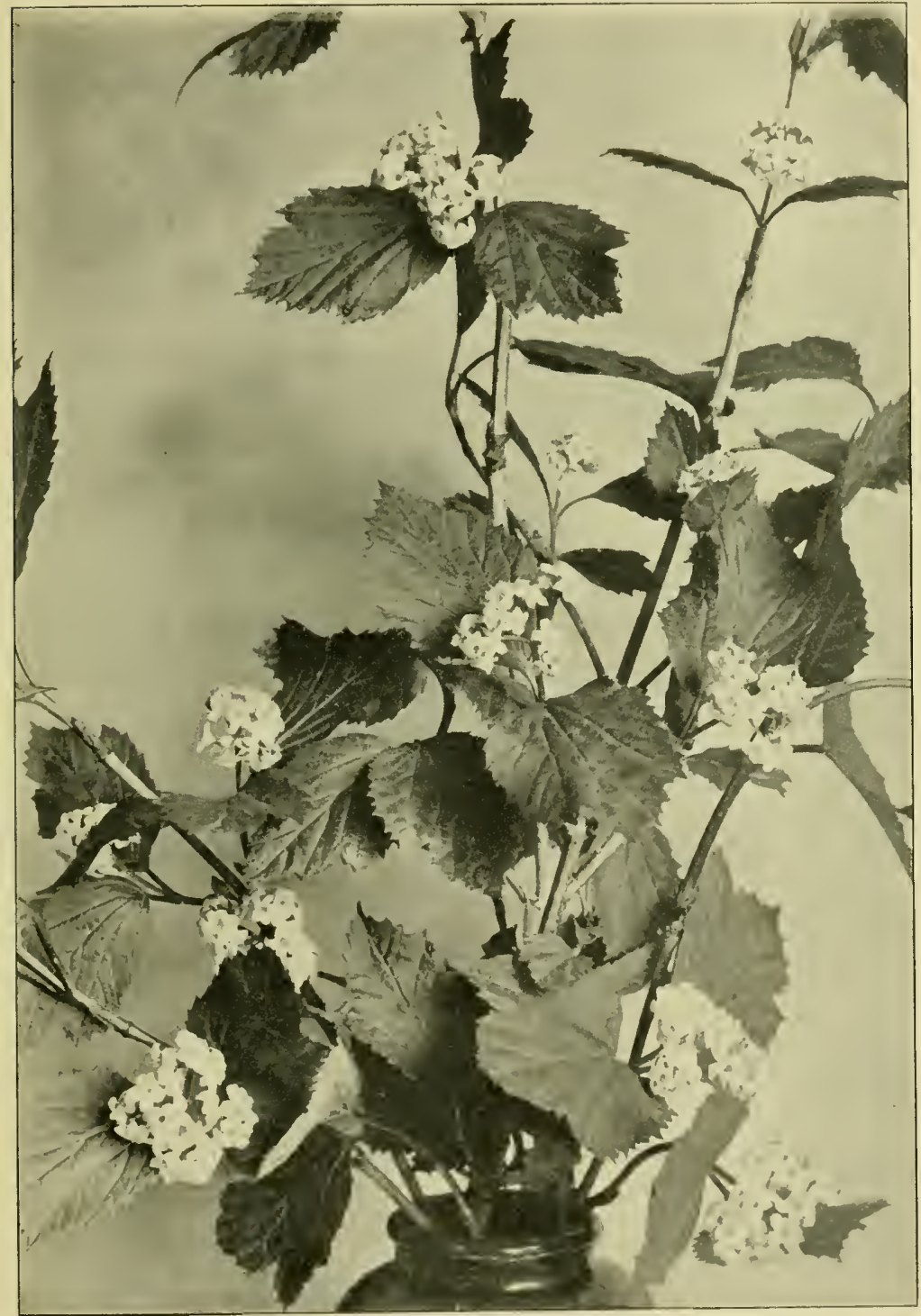

ARrow-WOOD

(I'iturnum fauciflorum) 



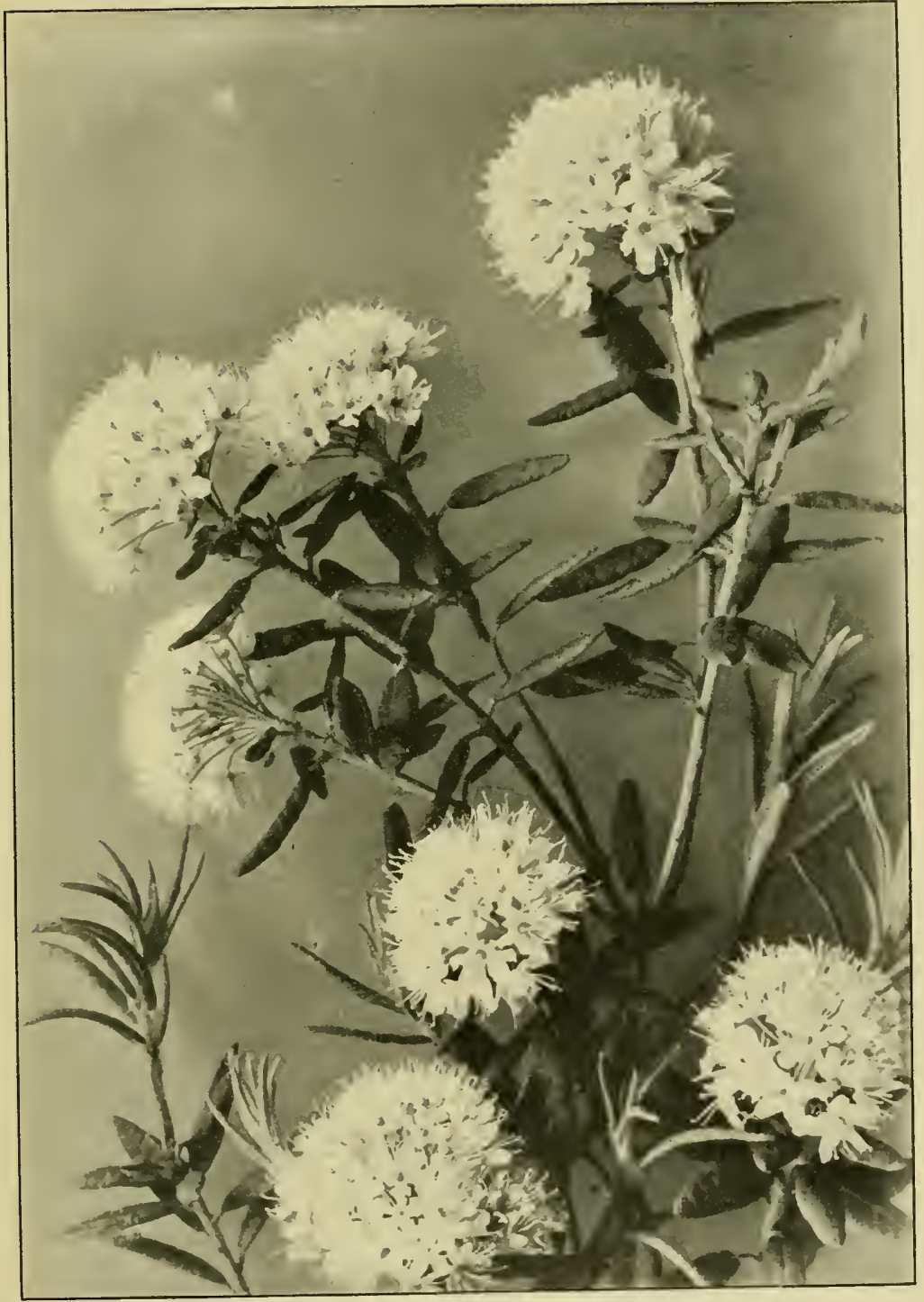

Wooley Labrador Tea (Ledum latifolium) 

at the joints. The leaves are oval, green above and covered with a whitish bloom beneath. The small pink and white flowers are formed like tiny toothed bells, and grow singly at the ends of the slender recurved stalks, which causes them to droop downwards. The berries also are pendent.

V. membranaceum, or Black Vaccinium, is not so tall as the preceling species, seldom attaining a height of six feet. The leaves are larger than those of the Blueberry, and are green on both sides and finely edged with very tiny teeth. The flowers are globular, and from their rounded corollas the long style protrudes. The recurved axillary stalks, which bear the blossoms, become upright in fruit and thus hold erect the large, sweet, purple-black berries, which have no bloom.

\section{WOOLLY LABRADOR TEA}

\section{Ledum latifolium. Heath Family}

Stems: erect or ascending, the bractlets rusty-tomentose. Leaves: oblong, obtuse, green and slightly rugose above, densely tomentose beneath, the wool soon ferruginous, and the margins strongly revolute. Flowers: umbellate or corymbose, numerous, terminal; petals five, spreading; pedicels brown-canescent, recurved in fruit.

This lovely flowering shrub thrives chiefly on low-lying flats and in wet marshy places, where its large teminal clusters of snow-white blossoms grow abundantly from sticky scaly buds on the low bushes. The foliage of the Woolly I abrador Tea is strictly characteristic, for the leaves are long-shaped, with revolute margins, green and slightly wrinkled on the top and densely woolly underneath, the wool in the developed foliage being the colour of iron rust. This thick wrolly growth is probably designed for the express purpose of protecting the pores of the leaves from becoming clogged by the moist vapours that must necessarily rise round about them, owing to the extremely wet ground in which the shrubs flourish. 
Plants that grow in very damp localities are specially dependent upon the free perspiration of their leaves to throw off the vast quantities of moisture they absorb through their roots and stems; consequently such marsh shrubs as the Labraclor Teas are forced to adopt a regular system in order to prevent the pores of their leaves from becoming so congested with moisture from outside that they cannot perform their legitimate function of throwing off the moisture from within. The small branches are also covered with red, rusty, wool-like hairs.

The flower-clusters are very beautiful, each incividual blossom consisting of five pure white petals, with a large green ovary set in the centre; the style and numerous long stamens are very conspicuous. Both the flowers and leaves have a strong aromatic fragrance.

L. slandulosum, or Smooth-leaved Labrador Tea, has also long-shaped, thick, leathery leaves of a brownish-green hue, but they are not woolly underneath, being quite smooth on both sides, though slightly white and resinous below. The flower-clusters closely resemble those of L. latifolium.

The name Labrador Tea is derived from the fact that many old settlers, and also campers and lumbermen in the backwoods, formerly used in place of tea a decoction brewed from the aromatic leaves of this shrub.

\section{WHITE MOUNTAIN RHODODENDRON}

Rhododendron albiflorum. Heath Family

Leaves: membranaceous, oblong, obscurely undulate. Flowers: from separate one-to-three flowered, lateral, scaly, cone-like buds below the leaves: calyx five-parted, the divisions more or less foliaccous ; corolla five-lobed; filaments bearded at the base, open-campanulate; stamens ten; style peltate, five-lobed. 
PLATE XCVII

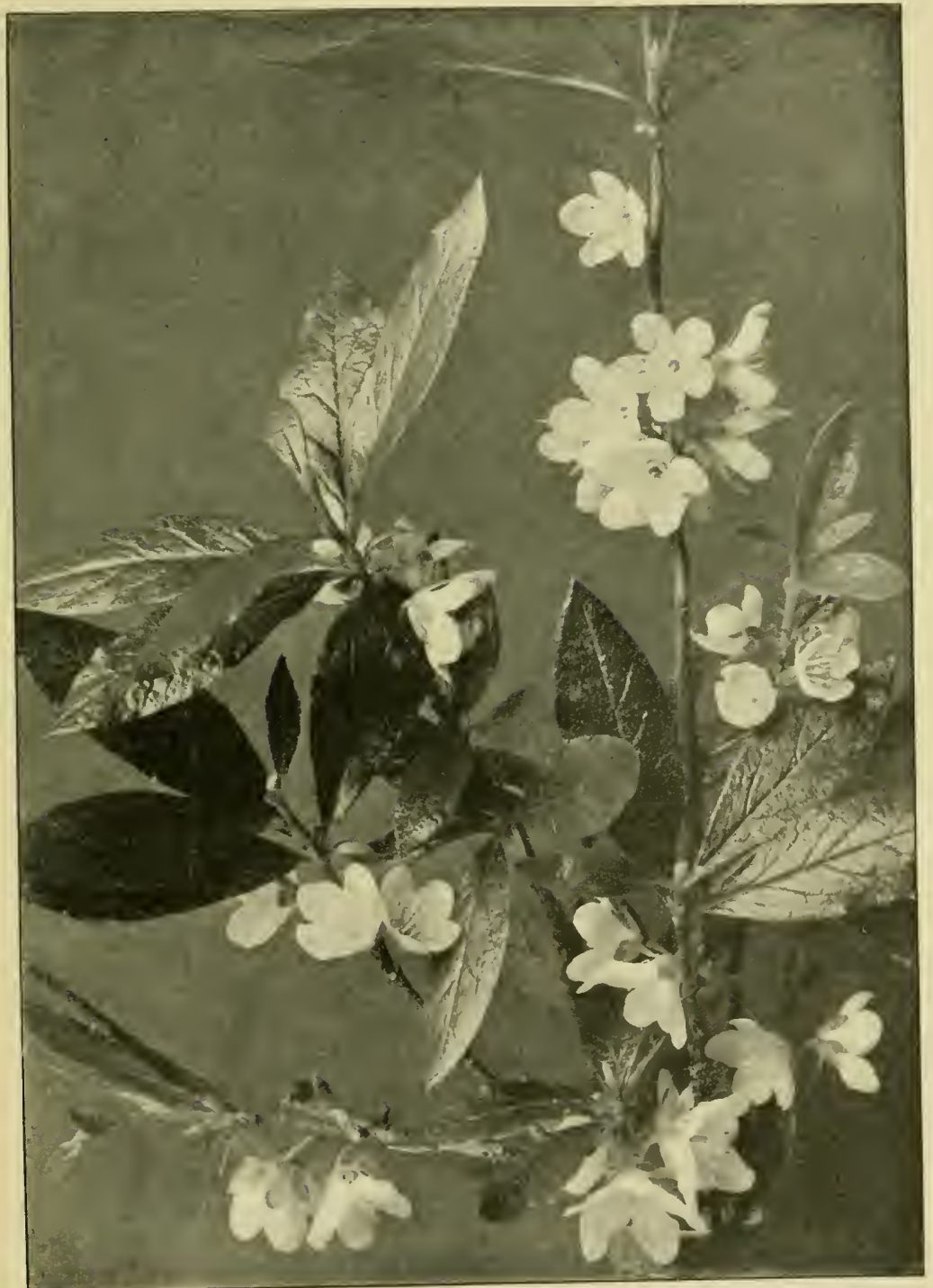

White Mountain Rhododexdron (Khododendron albiflorum) 

This is one of the most beautiful flowering shrubs found growing on the highest mountains.

"Oh, the windings up and down

That the dizzy pathway took!

Now along the craggy bed

Of a sun-dried mountain brook:

Now along a ledge that led

By a chasm's crumbling brink,

Dropping deep and sheer away

Through the golden Syrian day

To the dreamy blur of pink

That the oleanders made, -

Here in sun, and there in shade.

$\mathrm{Up}$, and up, and up we went,

While, a spacious azure tent,

Arabesqued with morn, the sky

Hung above us radiantly."

Had the poet who penned these lovely lines referred to

... the creamy blur of white

That the rhododendrons made,

his rerses would as fitly have described the finding of the exquisite waxen bells of the Mountain Rhododendron as that of

"The dreamy blur of pink

That the oleanders made,"

for it is on the most inaccessible ledges, and close to the great slopes of eternal snow, that the oblong glossy green leaves of this alpine shrub gleam brightly in the sunshine of the July days, and the slim, stiff, brown stems bear aloft clustering circles of pure white flowers, holding within their chalice-cups the ten pale yellow stamens and the style. The edges of the foliage are slightly wavy, the caly $\mathrm{x}$ is five-parted, each division resembling a small leaf, and the corolla is bell-shaped and cut into five rounded lobes. The buds are scaly and cone-like. 


\section{SMOOTH MENZIESIA}

\section{Menziesia glabella. Heath Family}

Leaves: alternate, obovate, obtuse and glandular-mucronate at the apex, pale glaucous and glabrous beneath, sparingly pubescent above, the margins entire, crenulate, ciliolate. Flowers: one to five in umbels, cream and pink, spreading, becoming erect; calyx five-lobed; corolla urn-shaped, four-toothed; stamens eight, included. Fruit: seeds longappendaged at each end.

If you wish to be quite certain that the shrub before you is really Mcnisicsia glabclla, just break off a branch and smell it, and you will at once perceive the peculiar pungent odour of the skunk emanating from its stems and foliage. The bush grows erect to the height of six feet and bears abundant foliage. The leaves are small, oval, and pale green, and have even wavy hairy margins. The flowers are little roundish pink and creamy urn-shaped bells, which terminate the long slender stalks, and are four-lobed, having eight stamens within their cups. They grow in umbels at the ends of the twigs, and also encircle the stems just below the topmost clusters of leaves. When in fruit the seeds are characterized by long appendages at each end.

\section{SILVER-BERRY}

Elaggnus argenter. Oleaster Family

Stoloniferous, silvery-scaly, much branched. Leaves : alternate, oblong, ovate, densely silvery-scurfy on both sides, acute or obtuse. Flowers: one to three in the axils, pedicelled, fragrant; perianth silvery without, yellow within, tubular below, the upper part campanulate, four-lobed, the lobes ovate. Fruit: oval, silvery.

A most extraordinary and attractive shrub, growing from two to twelve feet high and entirely covered with a lovely silver coating. The leaves are small and very crinkled and wavy, and the flowers quite tiny, their bell-shaped four-lobed corollas being silvery on the outside and pale yellow within. The stems, branches, leares, and fruit are completely silvered orer and thus may be readily distinguished. 


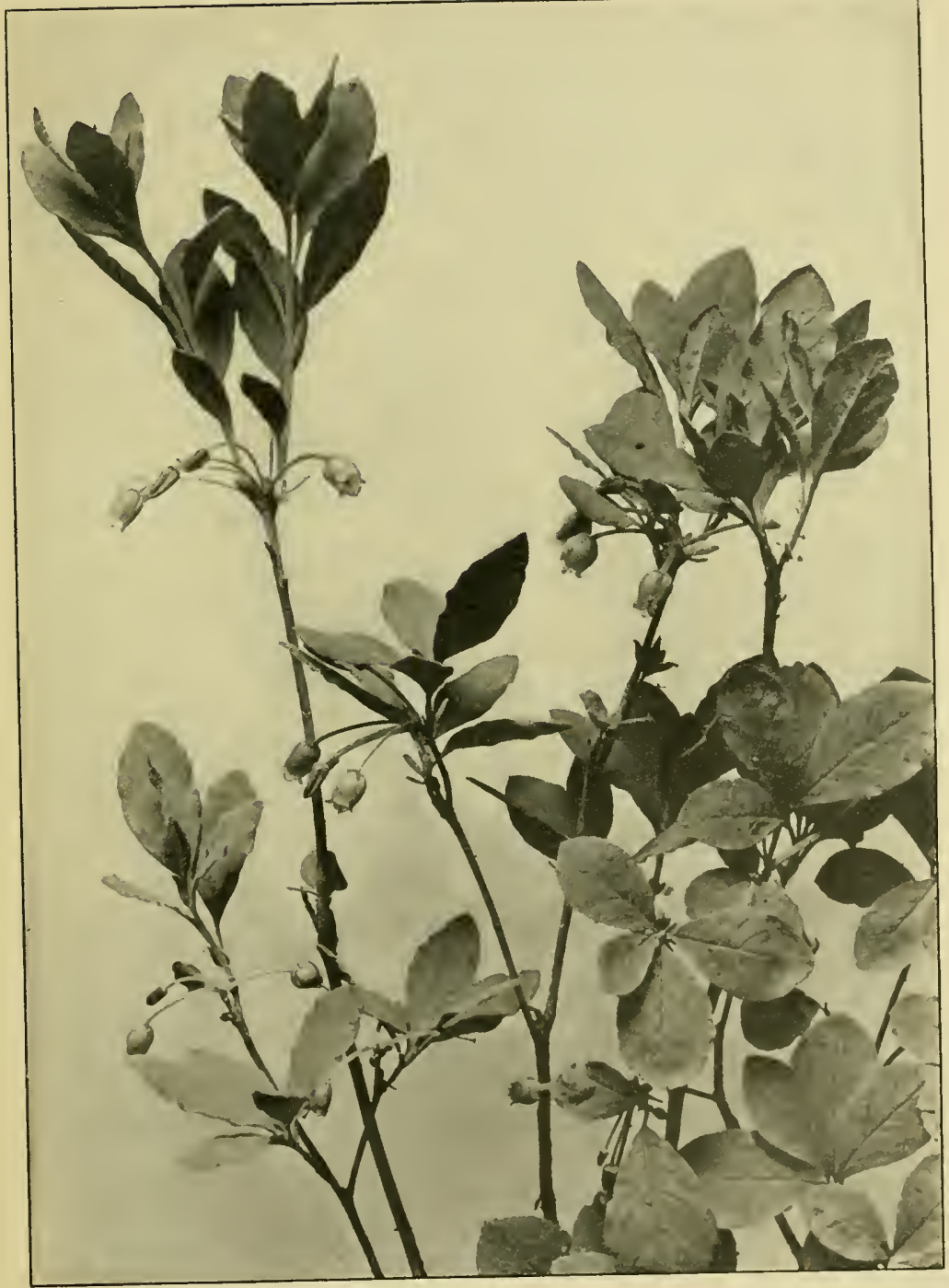

Smooth MexzifsiA

(Menziesia glabella) 



\section{CANADA BUFFALO-BERRY}

\section{Shepherdia Canatensis. Oleaster Family}

Leaves: ovate or oval, obtuse at the apex, rounded or narrowed at the base, green and sparingly stellate-scurfy above, densely silvery stellatescurfy beneath, some of the scurf brown. Flowers: in short spikes at the nodes of the twigs, yellowish, buds globose ; perianth four-lobed. Fruit: oval, drupe-like, red or yellow.

This shrub somewhat resembles Elaggnus argontca, but is not nearly so silvery in appearance, the stems being covered with a brown scurf and the leaves being green and slightly brown-scurfy on the top and silver-coated only underneath. The yellow flowers are small and grow in short spikes at the joints of the twigs; the fruit consists of a bright scarlet or yellow berry, the flesh of which is edible, though very insipid, and contains a tiny smooth nut.

The Canada Buffalo-berry grows from four to eight feet high, ustrally near water, and when in fruit is extremely ornamental.

\section{ROUGH-FRUITED DISPORUM}

\section{Disporum trachycarpum. Lily Family}

Leaves: alternate, ovate or oval, acute at the apex, rounded at the base, five-to-eleven nerved, sessile. Flowers : terminal, one to three on long pedicels, greenish-white or greenish-yellow ; perianth narrowly campanulate, its six segments narrowly oblong, acute, little. spreading; stamens six, hypogynous; style slender, three-lobed. Fruit: berry roughened, depressed-globose.

As its name implies, the Rough-fruited Disporum has a berry with a rough coat; it is apparently leathery rather than pulpy, and contains from four to eighteen seeds. This plant is not a real shrub, but is a shrub-like herb with slender rootstocks, and branching stems that are scaly below and leafy above. It usually grows in the dense woods and attains an average height of two feet. The leaves, which somewhat 
resemble those of Streptopus amplexifolius, are oval and strongly nerved, very pointed at the apex and rounded at the base. The flowers usually grow in twos or threes at the ends of the slender wand-like branches, where they hang pendent on their thready stalks. They are creamy or greenish-yellow in hue, and have a floral cup that is cut into six equal narrow segments and holds six long stamens, tipped by large oblong anthers, and a three-lobed style. 
MOUNTAIN WILD FLOWERS

OF AMERICA

$$
\text { Section VI }
$$

MISCELLANEOUS 



\section{Section VI}

\section{MISCELLANEOUS}

\section{SPIKED WATER MILFOIL}

Myriophyllum spicatum. Water Milfoil Family

Submerged leaves: in whorls of fours and fives, dissected into capillary divisions. Floral leaves : ovate, entire or serrate, usually shorter than the flowers, or sometimes none. Flowers: white, in spikes; petals four; stamens eight. Fruit: splitting at maturity into four bony, one-seeded, indehiscent carpels, which are rounded on the back, with a deep wide groove between them, smooth, or very rarely slightly rugose.

This is an aquatic herb, with submerged, spreading, thready leaves set in whorls of four or five round the thick stems. Sometimes it has floral leaves that are very small and usually shorter than the blossoms. The name Myriopliy'lum is from the Greek and means "myriad-leaved." The flowers are minute and white-petalled and grow in tiny interrupted spikes.

\section{MARE'S TAIL}

\section{Hippuris aulgaris. Water Milfoil Family}

Stems : slender, glabrous. Leaves: linear or lanceolate, acute, sessile, in crowded verticels of six to twelve, more or less sphacelate at the apex. Flowers : small, axillary; calyx-limb minute, entire; petals none; stamen one, with a short thick filament and comparatively large two-celled anther dehiscent by lateral slits. Fruit: a small, one-celled, one-seeded drupe.

This is also an aquatic herb, with slender erect stems, bearing circles of from six to twelve narrow leaves in the 
axils and curious tiny flowers that have no petals and only one stamen inserted on the margin of the calyx. The plant grows from eight to twenty inches high.

\section{STRAWBERRY BLITE}

\section{Chenopodium capitatum. Goosefoot Family}

Stems: ascending, erect, or prostrate, commonly much branched. Leaves: sinuate-dentate, cordate or reniform, the apex and basal lobes acute. Flowers: sessile in the axils and on the sides of the upper part of the stem, small, greenish, becoming bright red in fruit. Fruit: somewhat resembling a strawberry.

Strawberry Blite, or Indian Strawberry, as it is sometimes called, is a very appropriate name for this plant, which flourishes best in newly up-turned or half-cultivated soil, where its pale green foliage and bright red fruit render it conspicuous. The leaves are halbert-shaped, thin, and pointed both at the apex and at the ends of the basal lobes, the margins being more or less indented. The flowers are small and greenish, but the developed fruit is extremely attractive in appearance, consisting of a brilliant red pulpy berry, which has numerous seeds embedded in its wrinkled surface, similar to those which cover the exterior of the Garden Strawberry.

\section{WATER PERSICARIA}

Polygonum amphibium. Buckwheat Family

Aquatic, peremnial, glabrous when mature. Stems: floating or submerged, simple or sparingly branched. Leaves : oblong, elliptic, petioled, obtuse, sometimes ciliate; ocrex cylindric, those of the brauches often longer than the internodes, their limbs sometimes spreading. Flowers: small, in a terminal raceme, dense, erect ; calyx rose colour, five-parted; stamens five, exserted ; style two-cleft, exserted. Fruit : achenes orbicularoblong, lenticular, bicnnvex, black, smooth, shining.

The dense rose-coloured spikes of the Water Persicaria may frequently be seen rising above the surface of some 
forest pool, or fringing its borders. As Emerson has so aptly described it,

"Rosy polygonum, lake-margin's pride,"

is one of the prettiest aquatic plants amongst the mountains. The stems often grow twenty feet in length; sometimes they float, and sometimes they are immersed beneath the waters. The leaves are oblong-elliptic and smooth, and from two to four inches long.

\section{WESTERN DOCK}

Rumex occidentalis. Buckwheat Family

Stems : stout, strict, erect, leafy, strongly grooved, simple or sparingly branched. Leaves: lanceolate, papillose, obtuse at the apex, cordate at the base, long-petioled. Flowers: green panicle rather dense, erect, flowers loosely whorled; calyx six-parted, pale green ; wings triangulateovate, undulate.

A large coarse plant growing several feet high, with a strongly grooved stem, huge, long-shaped, bluish-green leaves that are crisped and wavy-margined, and panicles of green flowers set in loose whorls near the apex of the stalks. These flowers have no petals, but only a green six-parted calyx, the three outer divisions of which remain unchanged in fruit, while the three inner sepals develop into wings.

R. acctosa, or Sorrel, is a much smaller plant and has arrowhead-shaped leaves.

\section{BLACK CROW-BERRY}

Empetrum nigrum. Crow-berry Family

Much branched, the branches spreading, densely leafy. Leaves: linear-oblong, crowded, thick, obtuse, the strongly revolute margins roughish. Flowers: very small, purplish, solitary in the upper axils; sepals and petals mostly three. Fruit: a black drupe, containing six to nine nutlets.

This black-berried herbaceous shrub resembles a Heath, and grows in large dense mats on the mountain sides at high 
altitudes. The numerous short branches are thickly corered with tiny narrow leaves; the purplish flowers are inconspicu ous, and the berries, which are large, round, and of a dul black colour, are a favourite fruit with the alpine birds.

\section{JUNIPER}

\section{Juniperus nana. I'ine Family}

A depressed rigid shrub. Leaves: all subulate, rigid, spreading, channelled and whitened on the upper surface, densely clothing the twigs, verticillate in threes. Flowers : in aments, axillary. Fruit: cones globose, berry-like, blue.

A very depressed, almost prostrate species of Juniper, which forms on the ground large circular patches that sometimes extend to ten feet in diameter. It grows at extremely high altitudes, and is one of the last signs of vegetation encountered near the tree-line. The leaves, which densely cover the branches, are channelled, and sometimes whitened on the surface; they are set in verticels of three on the twigs. The cones are berry-like, being rounded, smooth, and dark blue.

\section{LYALL'S LARCH}

\section{Larix Lyallii. Pine Family}

A small tree; branches horizontal and ascending, the branchlets and bud-scales densely pubescent with whitish hairs. Leaves : narrowly linear, without sheaths, in fascicles on short, lateral, scaly. bucl-like branchlets, deciduous. Flowers : in aments, short, lateral, monecious, staminate from leafless buds, the fertile buds commonly leafy at the base. red. Fruit : cones oblong, promptly deciduous.

Iyall's Iarch is a very lovely tree. It is not an evergreen. In September, if you look up to where the conifers greet the edge of the great white notes, you will see a zone of glorious flaming yellow foliage adorning the crags and cliffs, and separating the rich green Hemlock, Spruce, Pine, and Fir from the purity of the perpetual snows. This yellow sheen 


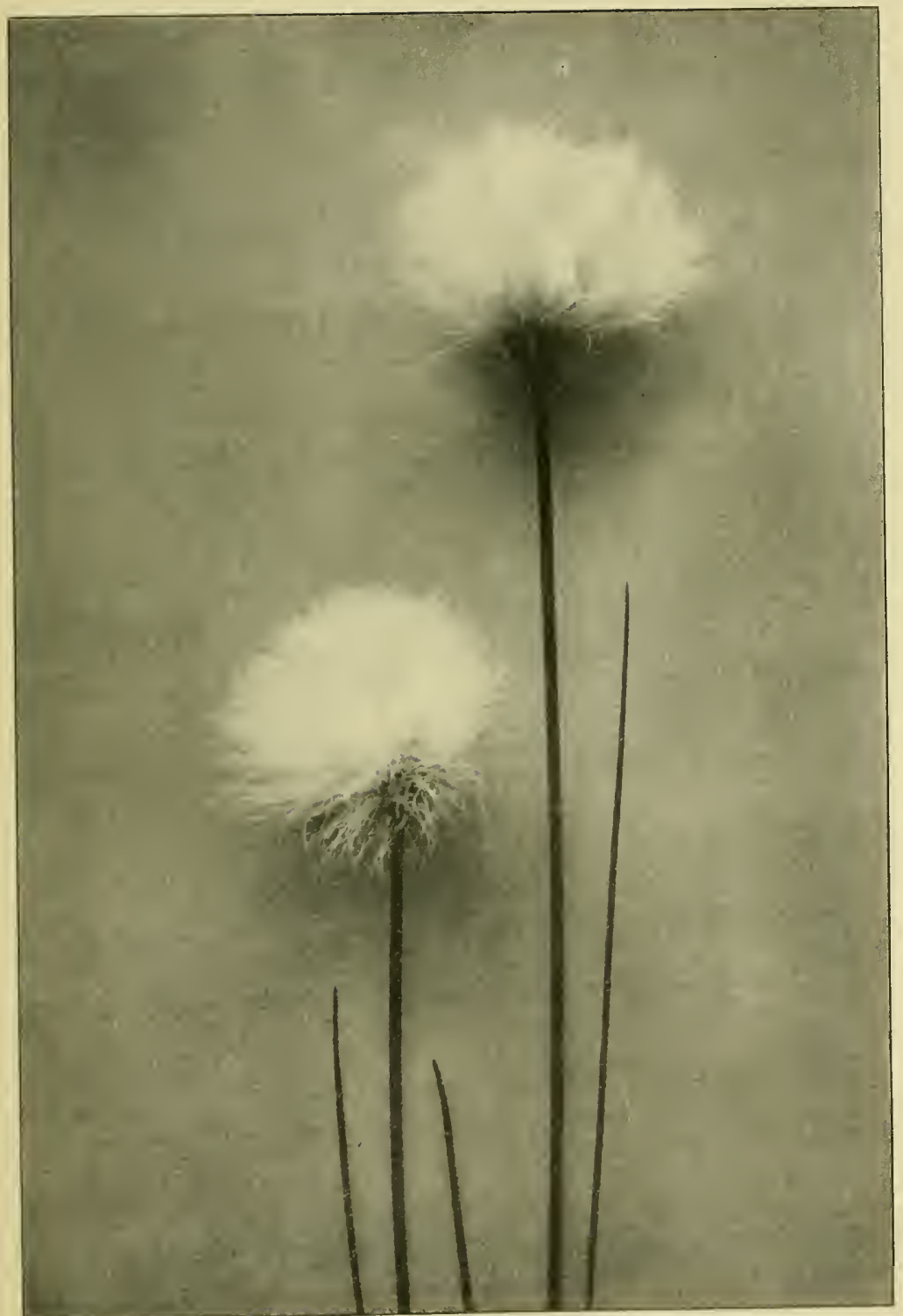

COTTON CiRASS

(Eriophorum capitatum) 

is the autumn dress of the Lyall's Larches; for when the brief alpine summer is past the leaves of these beautiful trees, which grow in clusters out of woody cups, and in July are a tender pale green, turn golden-hued before they fall.

The cones are small and dainty and soon drop off. It is very pleasant to pause awhile amongst a grove of these exquisite feathery apple-green Larches, and recall the words of one who said:

"Behind me lay the forests hushed with sleep;

Above me in its granite majesty,

Sphinx-like, the peak thro' silent centuries

Met the eternal question of the sky.

Victor at last - throned on the cragged height -

I scan the green steeps of the mountain side

Where late I toiled. The forest lands stretch wide,

And in deep valleys farms gleam far and white,

Vistas of distance break upon my sight.

The peopled plain creeps to the sky's blue rim,

Where new peaks gather substanceless and dim,

As half-remembered dreams at noontime light.

"Between two silences my soul floats still

As any white cloud in this sunny air.

No sound of living breaks upon my ear,

No strain of thought - no restless human will -

Only the virgin quiet, everywhere-

Earth never seemed so far, or Heaven so near.

In the awed silence of this dim high place

One keeping vigil might not fear, indeed,

If it befell him as that man of old,

Who in the mountain met God face to face."

\section{COTTON-GRASS}

Eriophorum capitatum. Sedge Family

Perennial by rootstocks. Stems: culm obtusely triangular, stiff, smooth, slender. Leaves : filiform, channelled: spikelet terminal, solitary, erect; involucre none; scales spirally imbricated, ovate-lanceolate, long-acuminate, purplish-brown, membranous; bristles numerous, white or slightly yellowish, weak. 
Close beside the margins of the alpine lakes and streams may this soft fluffy-headed sedge be found. It has a tall culm, two or three slender channelled leaves, and a single terminal white or cream-coloured head composed of fine silky bristles.

\section{SQUIRREL-TAIL GRASS}

\section{Hordeum jubatum. Grass Family}

Stems : culm erect, smooth, glabrous; sheaths shorter than the internodes. Leaves: flat, erect, rough ; spike terminal, cylindrical ; spikclets usually in threes, the central one containing a palet and perfect flower, the lateral ones imperfect.

The spikes of the Squirrel-tail Grass, with their warm, rich, reddish hue, when seen in large quantities, present a beaut1ful appearance as they swing and sway in the wind.

"In the summer of the summer, when the hazy air is sweet

With the breath of crimson clover, and the day's a-shine with heat, When the sky is blue and burning and the clouds a downy mass, When the breeze is idly dawdling, there is music in the grass -

"Just a t'istly, whistly sound

In the tangl s near the ground ;

And the flitting fairies often stop to listen as they pass ;

Just a lisping, whisp'ring tune,

Like a bumblebee's bassoon,

In a far-away fantasia, is the music in the grass.

"Would you know what makes the music? On each slender, quivering blade There are notes and chords and phrases by the bees and crickets played; And the grasshoppers and locusts strive each other to surpass In their brave interpretation of the music in the grass.

"By the roguish breezes tost

You might think it would get lost,

But the careful fairies guard it, watching closely as they pass.

So on every summer day,

Sounding faint and far away,

Is the mystic, murmuring marvel of the music in the grass." 


\section{FIELD HORSETAIL}

\section{Equisetum areense. Horsetail Family}

Stems: annual, hollow, jointed, provided with scattered stomata. the fertile appearing in early spring before the sterile. Leaves: reduced to sheaths at the joints.

This is a rush-like plant of a very rank coarse nature, which grows in ditches and along the sandy waysides. The fertile stems, which appear in the early spring, grow from four to ten inches high and are light brown in colour. They are not branched, but terminate in a solitary cone-like spike. The sterile stems, which appear later on in the season, are green and rather slender, averaging eighteen inches in height. They have numerous verticillate branches, the sheaths of which are four-toothed.

\section{STIFF CLUB-MOSS}

\section{Lycopodium annotinum. Club-moss Family}

Stems: much branched, slencler, prostrate and creeping, rather stiff, the branches ascending, sparingly forked. Leaves uniform, spreading, five-ranked, rigid, linear-lanceolate, minutely serrulate, nerved below; spikes solitary at the ends of the branches, oblong-cylindric, composed of orate bracts, each with a sporange in its axil; spores smooth on the basal surface.

A moss-like herb, with numerous tiny leaves completely covering the short branches, which terminate in dense oblong spikes composed of small bracts, each one with a sac containing spores in its axil.

L. clavatum, or Creeping Club-moss, has extensively creeping stems and short, irregular, densely leafy branches. The leaves are much crowded, incurved, and tipped with tiny bristles, and the spikes grow in clusters of from one to four on long peduncles. 



\section{INDEX TO SCIENTIFIC NAMES}

Achillea lanulosa, 74

Actara spicata var. arguta, 323

Allium recurvatum, 182

Allium Schonoprasum, 255

Amelanchier alnifolia, 337

Anaphalis margaritacea, 74

Androsace Chamajasme, 90

Androsace septentrionalis, 90

Anemone Drummondii, 9

Anemone multifida, 4

Anemone Nuttalliana, is6

Anemone occidentalis, 4

Anemone parviflora, 9

Antemaria Howellii, 73

Antennaria lanata, 73

Antennaria parvifolia, 73

Antennaria parvifolia var. rosea, 152

Antennaria racemosa, 73

Aplopappus Brandegei, 286

Aquilegia brevistyla, I9I

Aquilegia flavescens, 262

Aquilegia formosa, I 35

Arabis confinis, 15

Arabis Drummondii, IG

Arabis hirsuta, 16

A rabis 11 olbellii, 15

Arctostaphylos alpina, I 59

Arctostaphylos Uva-ursi, 156

Arenaria biflora, 27

Arenaria nardifolia, 27

A rnica alpina, $29 \mathrm{~S}$

Amica Chamissonis, $29 \mathrm{~S}$

Arnica cordifolia, : 17

Arnica Parryi, $29 \mathrm{~S}$

Artemisia biennis, 79

Artemisia discolor, 79

Artemisia frigida, 79

Aster alpinus, $6 \mathrm{~S}$

Aster commutatus, 68

Aster conspicuus, 213
Aster Engelmannii, 219

Aster foliaceus, 214

Aster Fremonti, 214

Astragalus aboriginorum, 32

Astragalus adsurgens, 203

Astragalus alpinus, 20.4

Astragalus convallarius, 204

Astragalus hypoglottis, 20.4

Astragalus Macounii, 204

Berberis repens, 323

Brassica Sinapistrum, 268

Brunella vulgaris, $2.4 \mathrm{~S}$

Bryanthus empetriformis, 159

Bryanthus glanduliflorus, $S_{5}$

Bryanthus intermedius, 160

Caltha palustris, 262

Calypso borealis, 177

Campanula rotundifolia, 223

Capsella Bursa-pastoris, 16

Cassiope Mertensiana, So

Castilleia Bradburii, 173

Castilleia miniata, 170

Castilleia pallida, 170

Castilleia septentrionalis, 166

Cerastium alpinum var. Behring. ianum, $2 S$

Cerastium arvense, 27

Chenopodium album, 99

Chenopodium capitatum, $3^{6 S}$

Chrysanthemum Leucanthemum, 74

Chrysopsis villosa, 286

Claytonia sessilifolia, $2 \mathrm{~S}$

Clematis Columbiana, $\mathrm{I}_{5}$

Clintonia uniflora, 120

Cnicus eriocephalus, So

Cnicus undulatus, 220

Collinsia parviftora, 243

Comandra livida, 103 
Comandra pallida, 103

Corallorhiza innata, 103

Comus Canadensis, 62

Cornus stolonifera, $3+3$

Corydalis aurea var. occidentalis, 266

Crepis elegans, 302

Crepis nana, 302

Crepis runcinata, 302

Cypripedium acaule, $\mathbf{1} 78$

Cypripedium parviflorum, 3 I 4

Cypripedium passerinum, 114

Cypripedium pubescens, 313

Delphinium Brownii, 19 I

Delphinium Columbianum, 192

Dicentra formosa, I 39

Disporum trachycarpum, 363

Dodecatheon pauciflorum, 165

Draba alpina, 268

Draba aurea, 268

Draba incana, I6

Dryas Drummondii, 272

Dryas octopetala, $3^{S}$

Echinospermum floribundum, 234

Echinospermum Lappula, 239

Elaagnus argentea, 360

Empetrum nigrum, 369

Epilobium anagallidifolium, 147

Epilobium angustifolium, 144

Epilobium angustifolium var. canescens, 147

Epilobium IIornemanni, i4 $\mathrm{S}$

Epilobium latifolium, 147

Epilobium luteum, $2 \mathrm{~S}_{2}$

Equisetum arvense, 375

Erigeron acris, 219

Erigeron compositus, 68

Erigeron glabellus, 152

Erigeron lanatus, 220

Frigeron l'hiladelphicus, 220

Erigeron salsuginosus, 220

Erigeron uniflorus, 220

Eriogonum androsaceum, 100

Yriogonum umbellatum, 100

Eriophorum capitatum, 373

Erysimum parviflorum, 267

Erythronium giganteum, 318
Fatsia horrida, $33^{\mathrm{S}}$

Fragaria glauca, 43

Gaillardia aristata, 294

Galium boreale, 62

Galium triflorum, 67

Gentiana acuta, 230

Gentiana affinis, 233

Gentiana arctophila, 230

Gentiana Forwoodii, 233

Gentiana Macounii, 229

Gentiana propinqua, 230

Gentiana prostrata, 230

Geranium Carolinianum, 139

Geranium Richardsoni, 31

Geum macrophyllum, 275

Geum strictum, 275

Geum triflorum, 143

Goodyera Menziesii, 107

Goodyera repens, 107

Iabenaria bracteata, 108

Ilabenaria dilatata, 1 I 3

Habenaria hyperborea, ros

Habenaria leucostachys, 114

llabenaria obtusata, ios

Hedysarum boreale, 207

I Iedysarum boreale var, albiflorum, 37

IIedysarum Mackenzii, 140

II lianthus giganteus, 293

Ileracleum lanatum, 6 I

I Ieuchera ovalifolia, 56

1 lieracium gracile, 305

II ieracium Scouleri, 302

II ippuris vulgaris, 367

IIordeum jubatum, 374

Juniperus nana, 370

Kalmia glauca, 160

I arix 1,yallii, 370

Lathyrus ochroleucus, 32

I.edum glandulosum, 356

Ledum latifolium, 355

I.eptarrhena pyrolifolia. 50

I.igusticum apiifolium, 61

I.ilium Columbianum, 317 
I.ilium Philadelphicum, 314

Linnaxa borealis, 1 ts

Linum lewisii, 198

Listera convallarioides, 104

Listera cordata, 104

lithospermum angustifolium, 309

1.obelia Kalmii, 223

l.onicera glatucescens, 151

lonicera involucrata, 349

I,onicera L'tahensis, $35^{\circ}$

Lycopodium annotinum, 375

l.ycopodium clavatum, 375

Melilotus officinalis, $27 \mathrm{I}$

Mentha Canadensis, 248

Nenyanthes trifoliata, 95

Nenziesia glabella, 360

Mertensia paniculata, 239

Mimulus Lewisii, 165

Nimulus Langsdorfii, 310

Mitella Breweri, 55

Moneses uniflora, 80

Myosotis sylvatica var. alpestris, 240

Myriophyllum spicatum, 367

Nasturtium officinale, 15

Nuphar polysepalum, 265

(Enothera biennis, 2S2

Orchis rotundifolia, $17 \mathrm{~S}$

Orthocarpus luteus, 310

Oxycoccus vulgaris, 156

Oxytropis Lamberti, 272

Oxytropis podocarpa, $2 \mathrm{Cf}$

Oxytropis splendens, 207

()xytropis viscida, 207

P'apaver nudicaule, 266

Parmassia fimbriata, 61

l'amassia Kotzebuei, 61

l'arnasia montanensis, 56

I'edicularis bracteosa, 171

I'edicularis contorta, 96

Y'edicularis Gronlandica, 173

l'edicularis racemosa, 96,

l'enstemon confertus, 30 9

I'enstemon confertus var. carruleopurjurens, 244

I'enstemon Menziesii, 243
Petasites frigida, So

Jetasites palmata, So

Petasites sagittata, So

I'haca Americana, 32

Phacelia sericea, 233

l'hysaria didymocarpa, 268

P'inguicula vulgaris, 247

I'lantago major, 99

l'lantago K'ugelii. 99

J'olygonum amphibium, 368

l'olygonum viviparum, 100

l'otentilla Anserina, 276

l'otentilla arguta, 43,279

Potentilla dissecta, 276

Potentilla fruticosa, 330

l'otentilla gracilis, 279

J'otentilla Ilippiana, 279

l'otentilla nivea, 279

Potentilla Noregica, 279

Primula farinosa, 164

Primula Mistassinica, 164

Prunus Virginiana, 324

Pyrola asarifolia, 163

Pyrola chlorantha, 85

Pyrola minor, $\$ 6$

I'yrola secunda, 86

l'yrus sambucifolia, 336

Ranunculus acris, 259

Ranunculus aquatilis var. stagnatilis, 261

Kanunculus Cymbalaria, 261

Ranunculus Eschscholtzii, 260

kanunculus Macounii, 260

Ranunculus repens, 261

Ranunculus reptans, 261

Rhinanthus Crista-galli, 3 '3

Khododendron albiflorum, $35^{6}$

kibes rubrum, $33^{\mathrm{S}}$

Ribes setosum, $33^{S}$

komanzoffia sitchensis, 95

Rosa acicularis, 330

Rosa Macounii, 3.35

lubus arcticus, 143

kuluts Nutkanus, 329

Rulus pedatus, $3 S$

Kumex acetosa, 369

Rumex occidentalis, 360 
Sambucus melanocarpa, 344

Sambucus racemosil, 343

Saxifıaga aizoides, 280

Saxifiaga bronchialis, 43

Saxifraga cermua, 44

Saxifraga Lyallii, 44

Saxifraga nivalis, $5^{\circ}$

Saxifraga Nutkana, 49

Saxifraga oppositifolia, 213

Sedum frigidum, 144

Sedum stenopetalum, 2So

Senecio Balsamit $x, 299$

Senecio canus, 301

Senecio lugens, 301

Senecio triangularis, 301

Shepherida Canadensis, 363

silene acaulis, 197

Silene Macounii, 22

Silene noctiflora, 22

Sisymbrium Hartwegianum, 267

Sisyrinchium angustifolium, 251

smilacina amplexicaulis, 120

Similacina Canadensis, 120

Similacina stellata, 119

Solidago Canadensis, 289

Solidago decumbens, 290

Solidago Missouriensis, 290

Solidago multiradiata var. scopulorum, 290

Solidago nemoralis, 293

Sonch us arvensis, 306

Spiraea Aruncus, 329

Spira lucida. 37

Spira pectinata, 37

Spiranthes Romanzoffinna, 107

Sitachys palustris, $25^{I}$

Stellaria longipes, 27

Stenanthium occidentale, 126

Sitreptopus amplexifolius, 114

Streptopus brevipes, iss

Streptopus curvipes, 181
Streptopus roseus, is 1

Symphoricarpus racemosus var. pauciflorus, $3+4$

Taraxacum officinale var. lividum, 305

Taraxacum rupestre, 306

Tellima grandiflora, 50

Thalictrum occidentale, 10

Thaspium cordatum, 285

Thlaspi arvense, 21

Tiarella unifoliata, 55

Tofieldia glutinosa, 125

Trientalis Americana, 90

Trifolium hybridum, 31

Trifolium pratense, 140

Trifolium repens, $3^{1}$

Trollius laxus, 10

Troximon aurantiacum, 305

Troximon glaucum, 305

Vaccinium caspitosum, I 55

Vaccinium membranaceum, 355

Vaccinium Myrtillus, 155

Vaccinium oralifolium, $35^{\circ}$

Vaccinium Vitis-Idxa, I 55

Valeriana sitchensis, 67

Valeriana sylvatica, 67

Veratrum viride, 126

Veronica alpina, 244

Veronica serpyllifolia, 247

Viburnum pauciflorum, 344

Vicia Americana, zos

Vicia Cracca, zos

Viola adunca, 197

Viola Canadensis, 21

Viola cognata, 192

Viola glabella, 271

Zygadenus elegans, $13 \mathbf{I}$

Zygadenus venenosus, 13 I 


\section{INDEX TO ENGLISH NAMES}

Adder's Tongue. Iellow, $31 \mathrm{~S}$

Alum-root, 56

Androsace, Alpine, 90

Androsace, Sweet, go

Anemone, Alpine,

Anemone, Few-flowered, 9

Anemone, Western, 4

A plopappus, 286

Arnica, Alpine, $29 \mathrm{~S}$

Arnica, Chamisso's, 298

Arnica, Heart-leaf, 297

Arnica, Parry's, 298

Arrow-rood, $34 t$

Ash, Western Mountain, 336

Asphodel, 125

Aster, Alpine, 68

Aster, Engelmann's, 219

Aster, Fremont's, 214

Aster, IJairy Golden, 286

Aster, Large Purple, 2 I 3

Aster, Jeafy-bracted, 214

Aster, White, 68

Avens, Large-leaved, 275

Avens, Long-plumed, $\mathrm{I}+3$

Arens, Vellow, 275

Janeberry, ked. 323

Jearberry, Alpine, 159

Bearberry, Red, I 56

lieard-tongue, Blue, 244

leard-tongue, large l'urple, 243

lieard-tongue, Yellow, 30u

liedstraw, Northern, 62

Hedstraw, Sweet-scented, 67

lietony, Wood, 17.4

liblberry, Alpine, 155

lillberry Jwarf, 155

listort, $A$ lpine, 100

Bladder pod, 26,5

Bleeding heart, IVild, I 39
Blueberry, 350

brunella, 248

Buckbean, 95

Buffalo-berry, Canada, $3^{6} 3$

Iiunch-berry, 62

Buttercup, Macoun's, 260

Buttercup. Meadow, 259

Buttercup, Snow, 260

Butterwort, 247

Calypso, 177

Campion, Moss, 197

Campion, White, 22

Catchtly, Night-Howering, 22

Cherry, Choke, 324

Chickweed, Alpine, 28

Chickweed, Field, 27

Cinquefoil, Alpine, 279

Cinquefoil, Common, 276

Cinquefoil, Kough, 279

Cinquefoil, Shrubby, 330

Cinquefoil, Small, 279

Cinquefoil, Tall, 43,279

Cinquefoil, Woolly, 279

Clematis, Wild, is 5

('lover, Alsatian, 31

Clover, Red, ito

Clover, White, 3 I

Club-moss, Creeping, 375

Club-moss, Stiff, 375

Collinsia, Small-flowered, $2+3$

Coltsfoot, Arctic, So

Coltsfoot, Arrow-leaf, so

Coltsfort, I'alm-leaf, so

Columbine, I3lue, in I

Columbine, Westem, 1.35

Columbine, Vellow, 262

Comandra, Swamp, 103

Comandra, White, 103

Coral-rowt, 103 
Corydalis, Golden, 266

Cotton-grass, 373

Cow-Parsnip, 61

Cranberry, Mountain, I 55

Cranberry, Small, I 56

Crane's-bill, Carolina, 139

Crow-berry, Black, 369

Crowfoot, Creeping, 26I

Crowfoot, Water, 26I

Crowfoot, Yellow, 26r

Currant, Red, $33^{\mathrm{S}}$

Daisy, Ox-eye, 74

Dandelion, Alpine, 306

Dandelion, Common, 305

I andelion, Copper False, 305

I) andelion, Large-flowered False, 305

Devil's Club, 338

I)isporum, Rough-fruited, 363

Dock, Western, 369

Jogwood, Red-stemmed, 343

Dryas, Drummond's, 272

l)ryas, White, $3^{S}$

Elder, Black-berried, $3+4$

Elder, Red-berried, $3+3$

Eriogonum, Dwarf, 100

Eriogonum, Tall, 100

Everlasting, Alpine, 73

Everlasting, Mountain, 73

Everlasting, Mouse-ear, 73

Fverlasting, l'early, 74

Everlasting, l'ink, 152

Everlasting, White, 73

Flax, Wild, ios

Flealyane, Mpine, $2=0$

Flealane, Arctic, 220

Fleabane, Blue, 219

Filcabane, Daisy, 68

Fleabine, Iarge Purple, 220

Fleabane, lavender, 220

lileabane, kough, 152

lily Iloneysuckle, Bush, 350

lily. Inneysuckle, Involucted, 349)

forget-me-not, False, 23.4

Finget-me-not, True, 240
Gaillardia, Great-flowered, 294

Garlic, l'ink, 182

Garlic, I'urple, 255

Gentian, Alpine, 230

Gentian, Blue, 233

Gentian, I)warf, 230

Gentian, Four-parted, 230

Gentian, Large, 233

Gentian, Macoun's, 229

Gentian, Northern, 230

Geranium, White, $3^{1}$

Globe Flower, 10

Goat's Beard, 329

Golden-rod, Canada, 289

Golden-rod, Field, 290

Golden-rod, Gray, 293

Golden-rod, Mountain, 290

Golden-rod, Northern, 290

Gooseberry, Bristly, $33 \mathrm{~S}$

Grape, Rocky Mountain, 323

Grass, Blue-eyed, 251

Grass, Squirrel-tail, 374

Groundsel, Black-tipped, 30 I

Groundsel, Silvery, 30 I

Harebell. 223

Ilawksbeard, $\mathrm{Alpine,} \mathrm{j}^{\circ} \mathrm{z}$

Ilawksbeard, Many-flowered, 302

II lwksbeard, Naked-stemmed. 302

llawkweed, Hairy, 302

llawkweed, Small, 305

Ileath, White, So

Ileather, Pink False, 160

Ileather, Red False, 159

Heather, White False, 85

Iledysarum, Mackenzie's, 1 fo

IIedysarum, l'urple, 207

Iledysarum, IIhite, .37

IIeliotrope, White, 67

Heliotrope, Wild, 67

Hellebote, lialse, 126

IIoneysuckle, Smoth-leaved, 151

ITorsctail, Ficld, 375

Juniper, 370

I alsador Tea, Smonth-leaved, 356

lablackor Teas, Woully, 355

Iadies' Tresses, 107 
Lady's Slipper, Large Yellow, $3{ }^{\mathbf{I}} 3$

Lady's Slipper, Mountain, II

Lady's Slipper, Pink, i $7 \mathrm{~S}$

I ady's Slipper, Small Yellow, 314

Lamb's Quarters, 99

Larkspur. Blue, 192

Larkspur, Mountain, I9

Laurel, Swamp, 160

l.eptarrhena, 50

lily, I'hiladelphia, $3 \mathbf{t}$

lily, Western, 317

Lily, Vellow l'ond, 265

Lobelia, Brook, 223

loco-weed, 272

Lousewort, Contorted, 96

Lousewort, White, 96

1.ungwort, Tall, 239

Lyall's Larch, 370

Mare's Tail, 367

Marsh-Marigold, 262

Meadow-rue, Io

Melilot, Yellow, 2; I

Menziesia, Smooth, 360

Milfoil, Spiked Water, 367

Mint, Wild Canada, $2.4 \mathrm{~S}$

Mitre-wort, False, 55

Mitre-wort, True, 55

Monkey-flower, ked, $16_{5}$

Monkey-flower, Vellow, 310

M ustard, I Iedge, 267

Mustard, Treacle, 267

Mustard, Wild, z6S

Nettle. Hedge, 251

Orchis, Fly-spotted, 178

Orchis, Giant, 114

Orchis, Leafy, $10 S$

Orchis, long-bracted, ros

Orchis, Small, ros

Orchis, White ling, II 3

Orthroarpus, Vellow, 310

Oxytrope, Alpine, 207

Oxytrope, Inflated, 204

Oxytrope, Showy, 207

Paint-l)rush, Red Indian, I66

Paint-brush, White Indian, 170
Painted-cup, Bradbury's, 173

Painted-cup, Bright, 170

J'arnassus, A lpine Grass of, 6 I

Pamassus, Fringed Grass of, 6 t

I'amassus, Marsh Grass of, 56

Parsley, Wild, 6i

l'arsmip, Meadow, $28_{5}$

Pasque Flower, 186

l'edicularis, Long-beaked. 173

I'enny-cress, 2 I

l'ersicaria, W' ater, 368

I'hacelia, Mlountain, 233

Plantain, Common, 99

I'lantain, P'ale, 99

l'lantain, Rattlesnake, 107

l'lantain, Small Rattlesnake, 107

l'oppy, Arctic, 266

l'rimrose, lird's-eye, 164

J'rimsose, Dwarf Canadian, 164

Primrose, Evening, 2Sz

Puccoon, Narrow-leaved, 309

Queen-cup, I 20

Ragwort, Giant, 301

Ragwort, Golden, $29 \$$

Raspberry, Arctic, 1.43

Raspberry, Creeping, $3 \mathrm{~S}$

Rattle, Vellow, $3 \mathrm{I}_{3}$

Rhododendron, White Mountain, $35^{6}$

Kock-cress, Alpine, 15

Rock-cress, I)rummond's, 16

liock-cress, IHairy, 16

Rock-cress, Stony, 15

komanzoffia, 95

Rose, Macoun's, 335

Rose, l'rickly, 330

Rosewort, 144

Salmon-berry, 329

Sandwort, Arctic, 27

Sandwort, Rock, 27

Saxifrage, Alpine, 50

Saxifrage, Common, +3

Saxifrage, I,yall's, 44

Saxifrage, Mountain, 213

Saxifrage, Nodding, 44

Saxifrage, Tall, 49 
Saxifrage, Vellow, 2 So

Service-berry, 337

Shepherd's Purse, 16

Shooting Star, 165

Silver-berry, 360

Silver-weed, 276

Snow-berry, 344

Solomon's Seal, False, 120

Sorrel, 369

Spearwort, Creeping, 261

Speedwell, Alpine, 244

Speedwell, Thyme-leaved, 2.47

Spikenard, 119

Spirza, Alpine, 37

Spiræa, Birch-leaved, 37

Spring Beauty, zS

Star-flower, 90

Stenanthium, 126

Stichwort, 27

Stickseed, 239

Stonecrop, 280

Strawberry Blite, 368

Strawberry, Wild, 43

Sunflower, Giant, 293

Tellima, 50

Thistle, Sow, 306

Thistle, Wavy-leaved, 220

Thistle, White, So

Twayblade, Broad-lipped, 104

Twatblade, Ileart-leafed, 104

Twinflower, Northern, I.

I'wisted-stalk, Curved, 18 I

Twisted-stalk, P'ink, IS I

Twisted stalk, Short-stemmed, ISI

Twisted stalk. White, 11 f

Vaccinium, Black, 355

Vetch, Alpine, 204
Vetch, American, 208

Vetch, Arctic, 32

Vetch, Ascending, 203

Vetch, Cow, 208

Vetch, Indian, 32

Vetch, Macoun's, 204

Vetch, l'urple, 204

Vetch, Slender, 204

Vetch, White, 32

Violet, Canada, 2 I

Violet, Dog, 197

Violet, Early Blue, 192

Violet, Vellow, $27 \mathrm{I}$

Water-cress, 15

Whitlow-grass, Alpine, 268

Whitlow-grass, Golden, 268

Whitlow-grass, White, 16

Willow-herb, Alpine, $1+7$

Willow-herb, Great, $1+1$

Willow-herb, Homemam's, 148

Willow-herb, P'ink, 147

Willow-herb, Water, 147

Willow-herb, Vellow, 2Sz

Wind-flower, 4

Wintergreen, Green-flowered, $S_{5}$

Wintergreen, One-flowered, S9

Wintergreen, One-sided, $\$ 6$

Wintergreen, Red, $16_{3}$

Wintergreen, Small, 86

Wormwood, Biennial, 79

Wormwood, Green, 79

Wormwood, Pasture, 79

Yatrow, 74

Zygadene, Poisonous, I3I

Zygadene, Tall, I 3 ' 






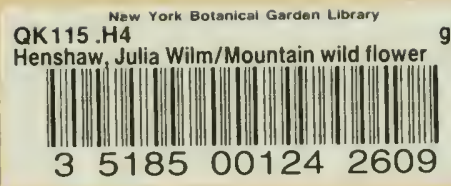


